Historic, Archive Document

Do not assume content reflects current scientific knowledge, policies, or practices. 



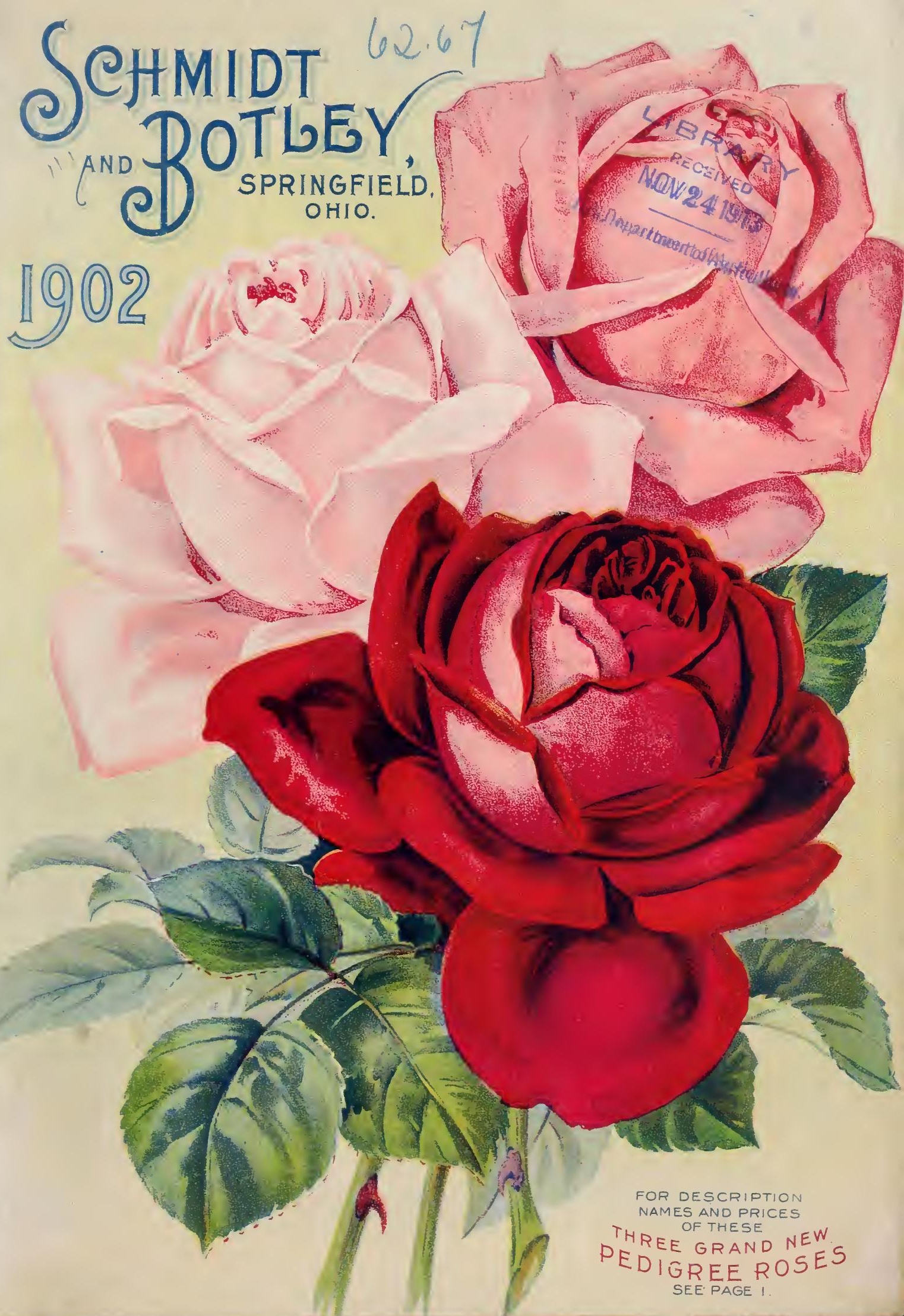




\section{"AMERICA"}

The Grandest Hardy Ever-Blooming Red Rose in the World. Hardy Everywhere. Blooms Continuously. Bears Flowers far Superior to the famous General Jacquiminot. Introduced and for sale only by $* * * * *$ SCHMIDT \& BOTLEY. $* * * * *$

(See color plate illustration on front cover page.)

$l^{\prime \prime m}$

HIS magnificent new Crimson Rose is, beyond question, the peer of any Rose yet introduced. It produces in great abundance exquisitely formed, large pointed buds, which open into beautiful double blooms of delicious iagrance. The color of bud and full blown flower is a pure, deep scarlet crimson, without a touch of purple in any stage of its development. The parentage of "America" would alone indicate its real worth. It is an offspring of two of the grandest and richest dark Roses heretofore sent out, viz: The well-known hardy dark red Rose, "Duke of Edinburgh," and the equally well known ever-blooming red Rose, "Meteor." "America" combines the good qualities of both these grand Roses, but is larger and produces more blooms then either of its parents. It is a strong grower with handsome dark green, leathery foliage, every shoot being crowned with a large. perfect bud of exquisite beauty. We own and control the entire stock of this magnificent new Rose, and would caution our friends that it cannot be bought elsewhere. Price, for strong one-year-old plants, splendidly rooted, 50c each; large two-year-old plants, $\$ 1.00$ each.

OUR GRAND NEW HARDY EVER-BLOOMING PINK ROSE,

66

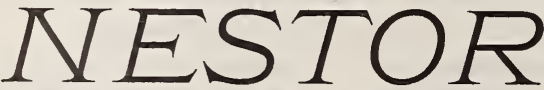

The Grandest Ever-Blooming Pink Rose

Yet Introduced. $* * * * * *$

(See Pink Rose, top of colored plate on front cover page.)

A S "America" is the peer of any dark red Rose, so is A "Nestor" the peer of any pink Rose yet disseminated. It is the offspring of two grand, well-known pink Roses, viz: "Magna Charta," the largest hardy pink Rose in the world, and the lovely new pink Rose, "Belle Siebrecht," the beautiful Rose which made such a furore among the Rose growers five years ago. The progeny of such parents would alone insure extreme hardiness, strong growth and a matchless profusion of bloom. "Nestor" inherits the splendid qualities of both its parents, combining the extreme hardiness and strong, vigorous growth of "Magna Charta" and the extreme free blooming tendencies of the lovely "Belle Siebrecht." It throws up enormous canes, which are crowned with immense blooms much like" $\mathrm{La}$ France" in form, but approaching "Belle Siebrecht" in color, being a soft, solid pink. It is very fragrant and will be grown largely for its inimitable buds and faultless color. We own and control the entire stock of "Nestor," and warn our customers that it cannot be proour three new Roses. cured at any other establishment than ours. Price, for strong one-year-old plants, 50c each: large, two-year-old plants, $\$ 1.00$ each.

OUR NEW HARDY EVER-BLOOMING SILVERY PINK ROSE,

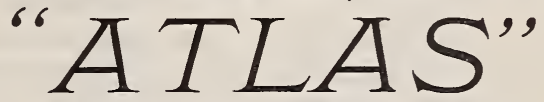

(See color plate illustrgtion on front cover page.)

THIS lovely new Rose is a daughter of the acknowledged Queen of Roses, the beautiful and well-known "La France." This fact alone would place it in the very front rank of high-grade Roses. Like its illustrious parent, "Atlas" is quite hardy, but is a much stronger grower and produces five blooms to "La France's one. It throws up long, quick-growing stems which are surmounted by long buds opening into large double flowers of two shades of pink exquisitely bright and fresh, The predominating color is light, silvery pink, as seen in illustration, and is exceedingly beautiful. We own and. control the entire stock of "Atlas," and advise our friends and patrons that it can be procured only at our establishment. Price, for strong one-year-old plants, 50c each; large two-year-old plants $\$ 1.00$ each.

\section{Yours very truly,}

WM. J. STEWART, Secretary.

Since receiving the above official communication, certificates of registration have come to hand for each of

\section{OUR SPEGIAL OFFER}

We will send one strong plant of each of these grand new Roses for $\$ 1.00$.

No further Discount on this Offer.

\section{OUR BEAUTIFUL NEW HARDY PHLOX. \\ (See colors from nature on last page of cover.)}

THE colored plate on the last or fourth page of cover gives the true colors of these six handsome new Phlox. No. 1 on plate is just about one half the natural size of this beauti-
ful sort. Nos. $2,3,4,5$ and 6 show their true colors, which were taken from nature, and they all have fully as large blooms as No. 1. This set of six hardy Phlox is the best and most distinct that money can buy. The plants we send will all bloom this summer.

No. 1-WILLIAM ROBINSON-Deep, rosy salmon with crimson eje. It is simply superb. Price, $15 \mathrm{c}$ each.

No. 2-DOLLY VARDEN - Pure white with beautiful rGsy pink eye. This is a very beautiful sort. Price, $10 \mathrm{c}$ each.

We will send this set of six handsome Phlox to any address for $50 \mathrm{c}$.
No. 3-ETNA-Bright red with maroon star in center. It is truly a beauty. Price, $10 \mathrm{c}$ each.

No. 4-SNOWFLAKE - Beautiful pure, glistening ivory white. Price, $10 \mathrm{c}$ each.

No. 5-AMORITE-White, overlaid with lilac, center rosy crimson, This is a very novel yet beautiful variety. Price, $10 \mathrm{c}$ each.

No. 6-EPOPEE-A lovely carmine crimson with a halo of pure white in center of flower, base of petals bright carmine. This is a magnificent Phlox. Price, 10c each. 


\section{* SCHMIDT \& BOTLEY'S * *}

SUPERB

PANSIES
0

UR SUPERB PANSY STRAIN is the very best the world produces. The colors are truly wonderful, including over a hundred different shades and combinations, with blendings and markings entirely new and of most exquisite beauty. Price, for splendid plants that will flower at once, 35c per dozen; 40 plants for $\$ 1.00$.
(See illustration on inside page of cover.)

\section{FOUR BEAUTIFUL REX BEGONIAS}

These four beautiful Rex Begonias are the best and

AS SHOWN ON THE INSIDE PAGE OF COVER easiest to grow of any of the Rex family. They delight in a moist, shady situation and make excellent house plants and for baskets and vases if not exposed to the full rays of the sun. They do best in light, open soil, composed of rich loam, loose woods earth and sharp sand.

\section{The Grand New Begonia,}

\section{KING OF REX}

Finest and largest leaved of any of the Rex family. Impossible to describe in words the beautiful markings of this magnificent Begonia. Cross between Begonia Diadem and a Rex variety, but retains in a marked degree the Rex character. Price, the Rex

The Lovely Siver-Leaved
Begonia,
R. GEORGE
A flne upright growing va-
riety. Very large, beauti-
fully lobed, rich, glossy silver
leaves with distinct palmate
center of bronze green. The
edge of leaf is metallic green,
dist in c t l y spotted silver,
Price; 15 c each.

- New Speckled Begonia,

\section{SPECULATA}

Quite a novelty in the Rex type. Leaves are in the form of a grape leaf. Color is a bright green, with a hackground of chocolate: reins of a light pea-green, this whole leaf spotted with silver In

bloom it is magnificent, the panicles, composed of great panicles, composed of great
- blowns, are lifted high and spray-like; quite clear of foliage. Price, $15 \mathrm{c}$ each.

The Handrome Bronze Begonia, CLEMENTINA

Upper surface of the leaf a beautiful loronze, ornamented with large silvery spots; the underwide of the leat is 8 bronyy resl, which produce i) ronzy rid, which produces each.

OUR SPLENDID OFFER-We will send one Strong Plant of each of these four Rex Begonias for 50c.

We wish to take advantage of this opportunity to in-
form our friends and customers that, owing to the unprece-
dented rush of business last spring, we unavoidably fell be-
hind in getting out and forwarding order. We worked day
and night, but in spite of our efforts, we conld not keep up.
This caused some of our patrons and ourselves considerable
annoyance.
We are glad to state, however, that we have, during the
past season, so arranged and increased our facilities for the
prompt handling of our fast increasing business that we can
and do guarantee the filling and forwarding of all orders, if
weather permits, not later than from one to four days follow-
ing receipt of order. Kindly bear this in mind when making
out your orders for plants, etc., this Spring.
We would also state that our facilities for propagating,
growing, packing, and shipping plants, etc, are not surpassed
by any house in the United States. We have the post-office
and all the leading express companies, whose wagons call at
our establishment every day, almost at our door. Trains
also leave our city at frequent intervals during the day for
all parts of the country -thus making our shipping facilities
unsurpassed.




\section{IMPORTANT ANNOUNCEMENT}

PLEASE READ THIS PAGE CAREFULLY

\section{A FEW WORDS ABOUT EXPRESS CHARGES}

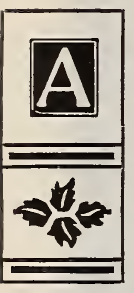

GREAT MANY of our customers have written to us stating that they much prefer having their plants sent by express, but complain about the heavy express charges which are very often due to overcharges by express agents. To remedy this, we give our customers their choice of paying the express charges on their plants themselves and get the benefit of our liberal Express Clubbing Rates, which see below, or we will prepay the express charges ourselves on all orders that amount to $\$ 3.00$ or more, in which case the Express Clubbing Rates cannot be allowed. All orders that amount to less than $\$ 3.00$, to be sent by express, we cannot prepay, but they are, of course, entitled to the Express Clubbing Rates. To show the great advantage our customers derive from paying the express charges themselves, and thereby taking advantage of Express Clubbing Rates, we herewith give the average express charges on $\$ 3.00, \$ 5.00$ and $\$ 8.00$ orders:

The express charges on a $\$ 3.00$ order will average from 50 cents to 75 cents according to the express rate to the point where the order is from.

On a $\$ 3.00$ order, when purchasers pay the express charges, we allow them to select extra plants to the amount of $\$ 1.50$ - a clean gain to the purchaser of from 75 cents to $\$ 1.00$.

The express charges on a $\$ 5.00$ order will average from 75 cents to $\$ 1.50$, according to the express rate to the point where the order is from.

On a $\$ 5.00$ order, where purchasers pay the express charges, we allow them to select extra plants to the amount of $\$ 3.00$-a clear gain to the purchaser of from $\$ 1.50$ to $\$ 2.50$.

The express charges on a $\$ 8.00$ order will average from $\$ 1.25$ to $\$ 2.25$, according to the express rate to the point where the order is from.

On a $\$ 8.00$ order, where purchasers pay the express charges, we allow them to select extra plants to the amount of $\$ 5.00$ - a clear gain to the purchaser of from $\$ 2.75$ to $\$ 3.75$.

Larger orders will, of course, receive, pro rata, a still greater rate of discount.

SEE OUR MAIL AND EXPRESS CLUBBING RATES A careful perusal of our Mail and Express Club= bing Rates will convince our flower-loving friends that our inducements for the formation of clubs, as well as for individual orders, are exceedingly liberal.

\begin{tabular}{|l|l|l|}
\hline 1 & Do Not Include Collections or Special Offers in Making Up Your \\
Discounts, as it Applies Only to Price Per Single Plant or Bulb.
\end{tabular}

MAIL CLUBBING RATES.

Any person sending $\$ 1$ select plants to the value of 25c. extra Any person sending $\$ 2$ select plants to the value of $60 \mathrm{c}$. extra Any person sending $\$ 3$ select plants to the value of $85 \mathrm{c}$. extra Any person sending $\$ 4$ select plants to the value of $\$ 1.25$ extra

Any person sending $\$ 5$ select plants to the value of $\$ 1.75$ extra Any pers on sending $\$ 6$ select plants to the value of $\$ 2.50$ extra Any person sending $\$ 8$ select plants to the value of $\$ 3.00$ extra Any person sending $\$ 10$ select plants to the value of $\$ 5.00$ extra

\section{EXPRESS CLUBEING RATES.}

Any person sending $\$ 2$, select plants to the value of $\$ 1.00$ extra.

Any person sending $\$ 3$, and pays the express charges themselves, select plants to the value of $\$ 1.50$ extra. Any person sending \$4, and pays the express charges themselves, select plants to the value of $\$ 2.00$ extra. Any person sending $\$ 5$, and pays the express charges themselves, select plants to the value of $\$ 3.00$ extra. Any person sending $\$ 6$, and pays the express charges themselves, select plants to the value of $\$ 4.00$ extra. Any person sending $\$ 8$, and pays the express charges themselves, select plants to the value of $\$ 5.00$ extra. Any person sending $\$ 10$, and pays the express charges themselves, select plants to the value of $\$ 8.00$ extra.

Individual orders allowed the same discount as club orders. If plants are to be forwarded by Express always mention by which Express Company you wish them sent. 


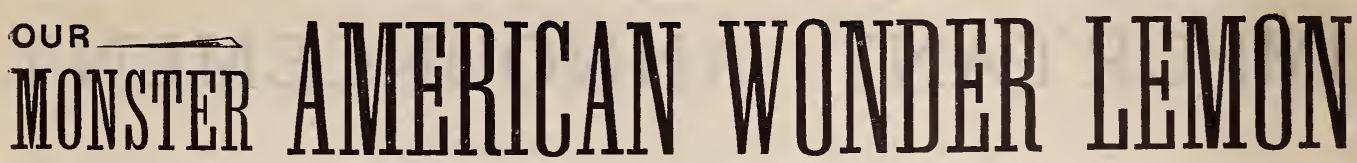

(SENT OUT BY SOME UNDER THE SPURIOUS NAME OF "PONDEROSA.")

\section{LARGEST AND FINEST EDIBLE LEMON IN THE WORLD}

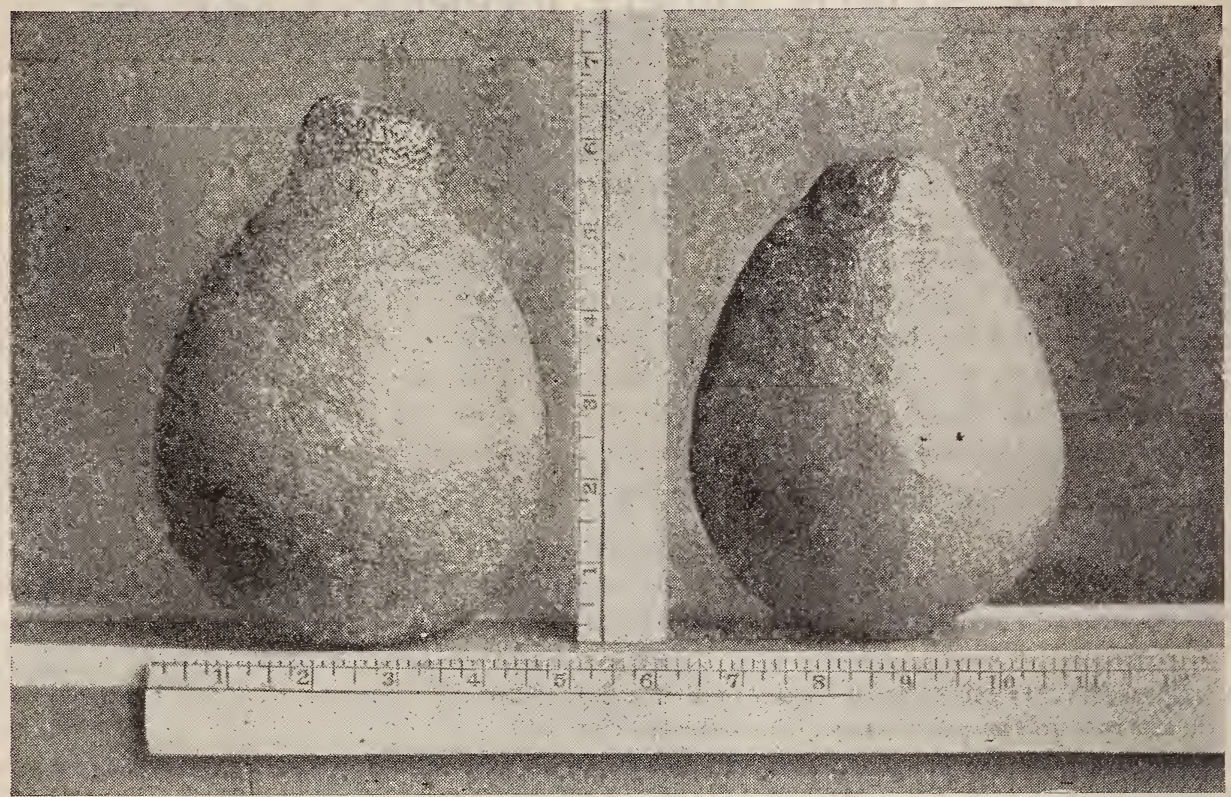

A greatly reduced photograph of two Lemons weighing four pounds twelve and one-fourth ounces, picked from our original parent tree, October 25 , 1901, there being no less than thirty-six of these mammoth Lemons on the tree at the time.

\section{THIS TRULY WONDERFUL LEMON}

TUAS INTRODUCED FOR THE FIRST TIME TO THE PUBLIC BY US in the Spring of 1899. Since $W$ that time we have grown and sent out thousands to all parts of the country, and the reports we have received from our patrons in all quarters as to its productiveness and size is very flattering. It is truly a wonder, for no other Lemon ever produced such enormous fruit or bore so freely. The plants grow rapidly and make shapely trees in a few months. The fruit is very handsome as well as useful. May be used anywhere that ordinary Lemons may be used, and one of these is equal to eight or ten common Lemons. Has very thin rind for such large fruit, and its acidity is unsurpassed Highly recommended for lemonade and all culinary purposes. In addition to its fruit bearing qualities it makes a. very handsome specimen plant for house culture. The dark green foliage is very large and handsome, and the pure, waxy-white flowers, with yellow stamens, are nearly as large as Tuberose blossoms and as fragrant as Orange blossoms, which they greatly resemble. We guarantee every tree to produce the same large fruit, no budding or grafting necessary. It is of the easiest culture, flowering and fruiting in any good, ordinary soil.

\begin{tabular}{|c|c|c|}
\hline * & $=P R I C E=$ & 橉 \\
\hline 橉 & $\begin{array}{l}\text { For very strong, young plants, from } 2 \frac{1}{2} \text { and } 3 \text { inch pots, } 15 \mathrm{c} \text { each, five for } 50 \mathrm{c} \text {; strong, handsome } \\
\text { plants, from } 4 \text { inch pots, } 25 \mathrm{c} \text { each; large, two-year-old plants, fruiting size, } 50 \mathrm{c} \text { each; very large, } \\
\text { handsome plants, out of } 7 \text { and } 8 \text { inch pots, exceptionally fine fruiting size, } \$ 1.00 \text { each. }\end{array}$ & 米 \\
\hline
\end{tabular}

NOTICE - We would call the attention of our patrons to the fact that some are sending out our AMERICAN Lemon, send to us. We are headquarters for it. We introduced it; we named it, and

WE HAVE BY FAR THE LARGEST STOCK IN THE WORLD OF THIS SPLENDID LEMON.

N. B.-Owing to the great demand for the 50 cent and $\$ 1.00$ sizes of our AMERICAN WONDER LEMON last Spring, we were sold out of these sizes lefore the close of the season. This caused some of our patrons and ourselves unavoidable annoy. ance. We have provided against this happening again by growing an immense quantity of these popular sizes and offer them this Spring in larger and better plants than ever in the 50 cent and $\$ 1.00$ size. 


\section{READ WHAT THE PEOPLE SAY OF OUR WONDERFUL LEMON.}

$\therefore$ COULD FILL PAGES WITH THESE BONA FIDE AND UNSOLICITED LETTERS of commendation clid space permit. "The proof of the pudding is in the eating of it." The proof of the genuineness of our claim tust we liave the most wonderful, the largest, the best, the most prolific and the casiest to grow of any Lemon in the world is surely demonstrated in the statements of hundreds of our patrons from all parts of the country.

San Antonio, Texas, Sept. 21, 1901.

SCHMIDT \& BOTLEY, Springfield Ohio.

Dear Sirs:-My "Wonder Lemon" is a fine shrub with eight temons on it. I send you dimensions of three: No 1, $13 \frac{1}{2}$ inches in circumference, $143 / 4$ inches in length; No. 2, 1 inches in circumference, $14 \frac{1}{2}$ inches in length: No. $3,141 / 4$ change color on the tree? Yours truly, Miss E. M.

Corpus Christi, Texas, Sept. 21, 1901.

\СHIDT \& BOTLEY, Springfield, Ohio.

Gentlemen:-I received jour Fall catalogue. This reminded me of the promise I made to write you again about the "Wonder Lellion." It is indeed the Lemon of Lemons. Iun will remember in niy testimonial of it in 1899 , I stated they hud frozen to the ground, as did all other Lemon and Orange trees I had in Februaly of that year. About the first Orange trees had in Febluary of that year. About the first Lemons larger than the largest commercial Lemons sold in the inarkets. It is indeed an American wonder. Yours truly, JNo. A. S.

New Hope, Alabama, March 1, 1901.

SCHMIDT \& BOTLEY, Springfield, Ohio.

I must tell you of the pleasure I have realized from articles bought from you. The Lemon is indeed a wonder. I have pulled three ripe ones, but did not think of weighing them until I read testimonials in catalogue, after which I measured one. It was $15 \frac{1}{2}$ inches one way, and $1 \mathrm{~d} 1 / 2$ inches the other, and weighed 20 ounces. I still have one which is a wonder. and weigher tasted better lemonade or pies. I lost three of the I never tasted beter leinonade or pies. I lost three of the seventeen Roses last year, but the others have done well-
some of them 14 feet high. The Gen. Washington is a real beauty. So, if I have success with my present order, I shall consider myself rich in Roses.

$$
\text { Yours truly, MRs G. M. H. }
$$

Mayodan, N. C., April i2, 1901.

SCHMIDT \& BotLEY, Springfield, Ohio.

Dear Sirs:-Two y ears ago I bought one of your American Wonder Lemons. Mine was a two-year-old plant when purchased and was in full bloom when received and the first year boresix large, fine Lemons averaging 10 ounces. Last year it bore ten, all larger and finer than those of the previous year. I value my plant very highly and want my friends and relatives in Mississippi to have them. Enclosed find express money order for $\$ 2.00$, for which please send two American $W$ onder Lemons third size, extra large fruiting size, $\$ 1.00$ each) to Mrs. J. M. G., Aberdeen, Miss. I wish to add that I have gotten a number of Roses and hothouse flowers from you and they slways proved most satisfactory.

$$
\text { Very respectfully, MRs. W. C. R. }
$$

Robinson, Ill., April 29, 1901.

SCHMIDT \& BotLEY, Springfield, Ohio.

Gentlemen:- Enclosed find money order for $\$ 3.50$, for which please send ine the enclosed order as soon as possible. I have an American Wonder Lemon that is a mass of buds and lloom. I hope to have quite a number of Lemons set on it.

The American Wonder is all you claim for it.

SCHмIDT \& BotLeY, Springfield, Ohio, Ill., April 22, 1901.

I send you an order this day. Would like it sent about the 5th of May by express. In with my order I order one American Wonder Lemon, 50c size, to be sent to Mirs. M. E R. Anerican ber, and was so pleased with my Lemon tree which had two very large Lemons on. One of them measured $12 x 11$ inches, very large Lemons on. One of them measured $12 x 11$ inches, and pie. My tree bloomed again in February and has now several Lemons set with new shoots and blossoms starting. It was a great curiosity to everyone, being the only one in our village. I am very proud of it, I assure you. It was received two years ago this coming May, a little plant not more than 1 . two years ago this coming May, a litte plant not more than 1 inches high. I want you to send a two-year-old bearing size to the lady whose address I send. Send Lemon first of May, 4.00. I hope you will send me nice plants. I was very much pleased with my plants last year. Send by American Express. Respectfully. Mrs. Jeñie E. B.

SCHMIDT \& BotLeY, Springfield, Ohio.

$$
\text { Dexter, Mo., Feb. } 2 \pi, 1901 .
$$

\section{Gentlemen:-}

Lemon trees in bloom. It has about fifter foliage leaves. The tree is all around a wonderful tree.

$$
\text { Yours truly, ARThUR H. }
$$

San Antonio, Texas, Feb. 1, 1901.

SCHMIDT \& Butley, Springfield, Ohio.

The American Wonder Lemon we had from you had four of the finest Lemons, weighing from 26 to 31 ounces, and measuring 16 inches in circumference. Please send the plants by express, and oblige,

Yours respectfully, MRs. F. S.

Philadelphia, Pa., Feb. 4, 1901

SCHMIDT \& Botley, Springfield, Ohio

Gentlemen:-The Lemon tree I bought from you some time ago has proved a wonder. It was covered with flowers and out of them I have three large Lemons. Respectfully,

C. A. ron $\mathrm{S}$.

Greenville, Tenn., Sept. 10, 1901.

SCHMidT \& Botley, Springfield, Ohio.

Dear Sirs:-My American Wonder Leinon I ordered last Summer is 5 feet, 8 inches in height from pot, and has one Lemon on measnring $11^{1 / 2} \times 13$ inches, and shows no si ons of ripening yet. Respectfully, C. A. S.

SCHMIDT \& BOTLEY, Springfield, Olio.

The orders sent to you by Mrs. Kell were for me. I am an old gardener and worked for Peter Henderson and also for Isaac Buchanan in 1854-5. So you see I am no Spring chicken. I had some dealing with that Ponderosa outfit two years ago, and they sent some of the poorest stuff I ever saw. They wrote to say that they would make it all right, but I did not like to try them again. I ain putting up a small greenhouse and when I come to stock it I will remember your firm. This order is for a friend. Last order came promptly and in fin
Respectfully, JOHN B. Preston, N. C., Jan. 14, 1901.

I am delighted with the Lemon tree I got from you last April, one year ago. It has done so inuch better than I expected it to do. It would have borne thirteen Lemons if I had not plucked five of them after they had gotten as large as an egg. Was afraid that it would tax tree too much. Just three weeks before Christinas I gathered two and used one to make cake, or a part of it. The other I sent to one of my neighbors. All who saw it say they have never seen any thing like it in the Lemon family before. I took one from the tree last Saturday that weighed 22 ounces and measured $15^{1 / 2}$ inches in circuinference one way and 14 inches the other. Isent that to friend of mine in smithfield, who will show it to many and also have our county paper, the Smithfield Herald, take notice of it, and hope the exhibit of it will result in a large sale of it
in smithfield for you.
Miss C. E. S.

Pottsboro, Texas, Jan 15, 1901.

SCHYIDT \& BOTLEY, Springfield, Ohio.

Kind Sirs :- I am much pleased with the Lemon tree I pur chased from you in the spring of 1899. Bloomed and fruited last Spring for the first time. Two Lemons remained on the tree and grew to a large size. One measured 14 inches around and caused quite a sensation. I have had many inquiries about $\mathrm{my}$ tree and think you will get a good many orders for them. Hoping you may get many orders, I remain,

$$
\text { Yours respectfully, MIss MARY U. }
$$

Lockport, Ills., April 8, 1901.

SCHMIDT \& BOTLEY, Springfield, Ohio.

Gentlemen:-I send 5 ou a small order including one Lemon, I bought one of your Lemons two years ago this spring, I have one Lemon on the tree that measures 17 inches in cireumference both ways, and is not ripe set, there are several small ones on it and it is still in bloom, I shall let three or four remain on the tree to ripen. The tree when in blossom scents the whole house and is worth all you ask for it, I am very proud of it and will notify you how the one I have just ordered gets along. Yours truly, W. C. MACD.

$$
\text { Alton, Mo., April 15, } 1901 .
$$

SCHMIDT \& BotLeY, Springfield, Ohio.

Gentlemen:-Your vlants arrised promptly and in good condition. I was highly pleased with them. My American Wonder Lemon, purchased from you last Spring, is now veritable beauty. It is quite large and is in full bloon, and
has been so for six weeks.

San Antonio, Texas, June 9, 1901. SCHMIDT \& Botley, Springfield, Ohio.

Last Spring I got of you two of your Wonder Lemons. at 50 cents. One of thern has now three enormous ILemons and is siu full bloom. Thes .00 size was laden with fragrant flowers in the Spring and now has sixty fille Lemons

Mr8. B. F. H. 


\section{OUR GREAT \$1.00 MAIL TRIAL COLLECTION FOR NEW CUSTOMERS.}

\section{\$2.35 GHOIGE PLANTS FOR $\$ 1.00$}

$\prod$ HIS COLLECTION is, as of strictly meritorious and up-todate varieties of plants. They are a fair criterion of the plants sent out from our establishment, and we guarantee them to be just as we represent them. This nice collection consists of the following choize plants: $⿻$ is $* * * \neq$

New hardy ever-blooming Rose, THE BALDWIN; rich, dark red.

New ever-blooming Rose, QUEEN OLGA OF GREECE; a grand pink Rose.

New ever-blooming Rose, SNOW. FLAKE; beautiful pure white.

New ever-blooming Rose, MAD. KRUGER; coppery-yellow, very fine.

1 beautiful King of Rex Begonia (see in side of cover.)

1 splendid double Petunia, ESMERALDA; purple and white.

1 Giant flowering Heliotrope, FLORENCE NIGHTINGALE.

1 handso:ı.e new Salvia, SILVERSPOT; lovely foliage, scarlet flowers.

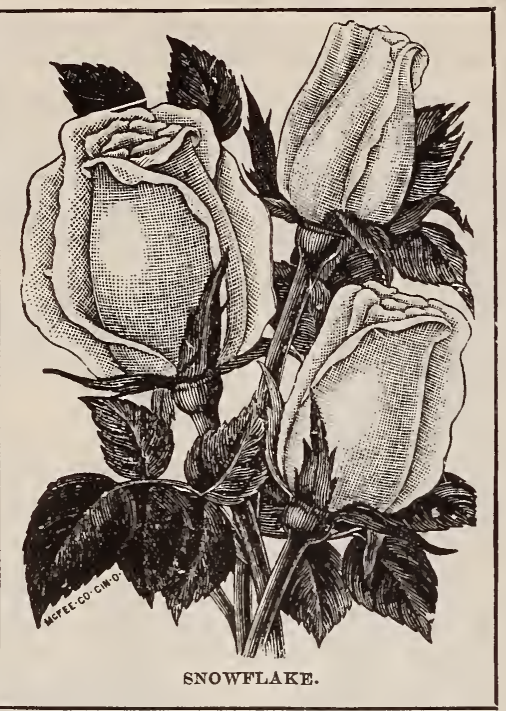

1 grand new Canna; superb flowers of largest size.

1 lovely Boston Fern; the best for house culture.

1 ever-blooming Paris Daisy, MAD. GAILBERT; large white flowers.

1 double blue Violet, LADY HUME CAMPBELL; very fragrant.

3 lovely, fragrant Carnations; ? distinct sorts.

3 of our choicest Geraniums; all distinct sorts.

4 of our best Chrysanthemums viz: GOLDEN WEDDING, yellow; SIL. VER WEDDING, white; MRS. PER. RIN, pink; DEFENDER, red.

Making in zll 22 of the very choicest plants f.r only $=\$ 1.00=$

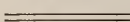

This is less than 5 cents each, and is certainly, a splendid bargain.

When ordering this Collection, please say \$1.00 MAIL TRIAL COLLECTION.

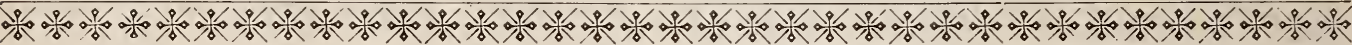

$\cong$ OUR BIG BARGAIN

\section{*XPRESS TRIAL COLLECTION}

EVERYTHING plainly labeled and packed as light as will be consistent with safety. It consists of : $\nsim \neq$

1 large handsome Boston Fern, best for house culture. Price, 20c.

1 fine Palm, from 5-inch pot. Price, 50c. 1 large plant of Rex Begonia. Price, 15c.

1 strong plant of Acalpha Sanderii; very fine. Price, $15 \mathrm{c}$.

1 large 2-year-old Hibiscus; large red flowers. Price, 20c.

1 American Wonder Lemon (see page 4). Price, 25c.

1 Handsome Australian Silk Oak. Price, $15 \mathrm{c}$.

4 of our best and most distinct Cannas. Price, 40c.

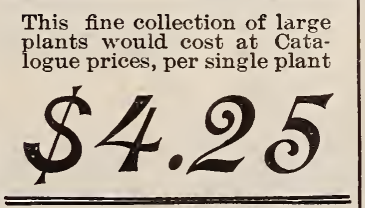

We will send the entire col. lection, by Express

$\boldsymbol{O} \boldsymbol{R}$ ONLY

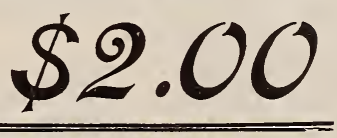

and we guarantee every plant to be just as representpland the largest and best assortment of choice plants assortment of choice plants the price. 0 o $\begin{array}{llllll}0 & 0 & 0 & 0 & 0 & 0\end{array}$
4 splendid "Mums," all distinct sorts. Price, $40 \mathrm{c}$.

3 large 2-year-old ever-blooming Roses, all different. Price, 75c.

3 choice Carnations, finest sorts. Price, $30 \mathrm{c}$.

3 of our best distinct Geraniums. Price, $30 \mathrm{c}$.

3 of our best flowering Begonias. Price, 30 c.

2 ever-blooming Paris Daisies, white and yellow. Price, 20c.

Making in all 29 splendid foliage and flowering plants for only $\$ 2.00 \equiv$

This spiendid Collection of plants sent by Express for only $\$ 2.00$

No further Discount Allowed on this very Liberal Offer. When ordering, please say "Big Bargain" Express Trial Collection. 


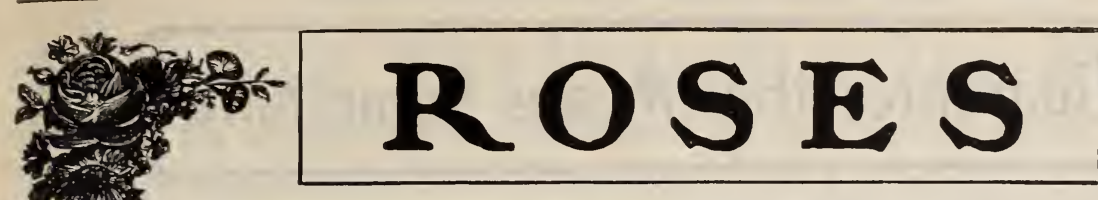

OUR LEADING SPECIALTY $\oslash$ WE HAVE THEM BY THE HUNDREDS of THOUSANDS

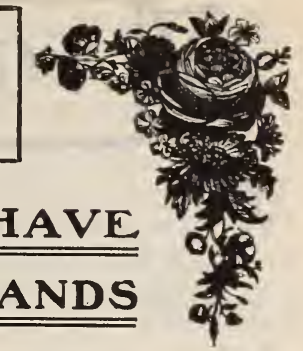

W

HILE our catalogue, as will be readily seen, contains a very choice assortment of all kinds of flowers, we wish to call your attention more especially to our very complete and choice list of Roses. We have gathered together not only in our own country, but also from foreign countries, all that is good. These we have thoroughly tested and we now have the pleasure of offering you the very cream of existing varieties and at the lowest price plants of good quality can be produced for. We have all kinds and classes of Roses, and best of all they are good strong plants, with clean foliage and healthy strong roots, being grown slowly in a cool temperature to attain this result. With our twenty-five years of experience, one of the largest and best equipped plant establishments in the west, personal supervision and attention to detail, we solicit your orders, confident that no one is more anxious to please or in better condition to give good service, full value, and satisfactory results.

We particuarly call your attention to our three new Pedigree Roses, illustrated on the first page of cover and fully described on the first page of catalogue. The illustration faithfully portrays the extreme beauty of these handsome new Roses and was made from flowers cut from the original stock. They are the exact color, shape and size of the blooms. The price we ask for the three is exceedingly cheap for such Roses, being less than 35 cents each. We ask, where could you buy such Roses elsewhere for the price?

Cour Superb Strain of Pansies, illustrated on inside of cover and described on page two of catalogue is something marvellous. All lovers of the beautiful should try at least a few of our famous strain. Give them a good, rich soil, and you will be delighted with the lovely new colors and size of flowers. Our superb strain is the choicest of all Pansies and only 35 cents per dozen.

The Four Choice Rex Begonias, illustrated on the inside of cover and described on page two of catalogue are also well worthy of your careful consideration. The four varieties we offer for 50 cents are the best and easiest to grow of all the Rex Begonias, and we strongly recommend them to all lovers of this very beautiful variety of Begonias.

We also call your attention to the magnificent collection of Hardy Phlox, illustrated on the outside of the cover and fully described on the first page of catalogue. The illustration was

made from natural flowers and the colors are depicted true to nature. So many of our customers ask us for something that is pretty and free blooming all summer and yet hardy-something that does not have to be taken up at the approach of winter, and that will be ready for blooming again the following summer. Our beautiful new hardy Phlox will be found satisfactory in the highest degree for this purpose and they increase in size and magnificence every year. The six we offer for 50c are the most varied and beautiful Phlox that grow. We heartily recommend them to everyone of our customers.

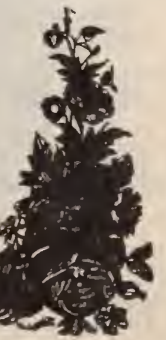




\section{A Guarantee that Means Something}

W

guarantee all plants to reach their destination in a good growing condition. We guarantee abso-

lute satisfaction to every purchaser of our goods.

If you think we have made a mistake, tell us so, or write to us. Try to do so good naturedly; if not, do it any way. Do not complain to anyone else or let it pass. We want an early opportunity to make right any unintentional error we may make.

Be Sure to Sign Name and Give Your Address.

Many orders reach us lacking either or both. Customers when writing about unsigned orders will aid us in identification by mentioning the articles ordered.

Our Plant and Seed Departments

Are entirely separate. Often the seeds or plants on.a com bined order may be sent before balance of order is filled. If only one part of order is received, please wait two or three days for the balance before writing us.

When Corresponding

Be careful always to sign your name the same way. Ladies sometimes send an order in their own name, and perhaps write again inquiring about the order in their husband's name. This often causes us much annoyance and waste of time. Do not mix your order and correspondence together.
If you wish to write concerning the order, write it on the back of the order or on separate sheet.

\section{Canada Postage.}

As postage to Canada is double the United States domestic rates we must ask our Canada friends to send 10 cents extra for each $\$ 1.00$ worth ordered. Do not send Canada postage stamps or silver as we cannot use or dispose of them. Roses and all hard-wooded plants are by law prohibited entrance into Canada.

\section{When Ordering}

Always state when you wish the goods shipped, otherwise they will be sent you at once. Send in your order early while stock is complete and unbroken. If you do not wish plants forwarded until later date we will reserve plants and forward when desired.

\section{Remittances}

Shonld be made either in the form of P. O. Money Order Bank Draft, Express Money Order, or Registered Letter. Remittances in any other way are entirely at the sender's risk.

Address all Letters, and make Drafts, Money Orders, etc., payable to

\section{SCHMIDT \& BOTLEY, Springfield, Ohio.}

BOWKER'Sø๑ळ AMMONIATED FOOD $\varnothing \varnothing \varnothing \varnothing \varnothing$ FOR FLOWERS
A NEW ODORLESS FERTILIZER FOR POT PLANTS

Makes plants grow and blooln luxuriantly, and drives insects from the soil. It starts the plants at once into a healthy and vigorous growth and abundant bloom. It drives worms and other troublesome insects from the soil. It has no disagreeable odor, and is the only Artificlal Fertilizer which can be used without danger or injury to the plants. It takes the place of liquid manure, and is just the thing that has been wanted for a long time. We have sold tens of thousands of packages of it, and have yet to hear the first complaint. If your plants are doing poorly get a package and see how quickly they will be benefited. It acts like a charm. The Ammoniated Food is put up in wooden boxes, with attractive wrappers. One package, sufficient for twenty-five ordinary-sized plants for one year, for 50 cents. Sent by mail, postage prefaid on receipt of price.

\section{SLUG SHOT KILLS BUGS.}

A powder destructive to insects that are injurious to house and garden plants, shrubs, trees, vines, potatoes, melons, cabbage, currants, etc. Used in all latitudes since 1880, with safety to man, beast and fowl. Put up in perforated screw-top canisters, and is handy to use, mere dusting on the plant with the can. If you are troubled with insects on your Rose bushes, we recommend you to try this. It does its work quickly and thoroughly.

PRICE 50 CENTS PER CANISTER.

Sent by Mail, postpaid, on receipt of price.

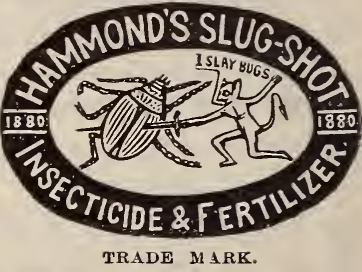

Our Fall Catalogue On the first of Septemberwe issue a Catalogue of Bulbs and Plants for Fall Planting and Winter blooming, such as Hyacinths, Tulips, customers of this and last year, and we will also send it free to others who wish to order.

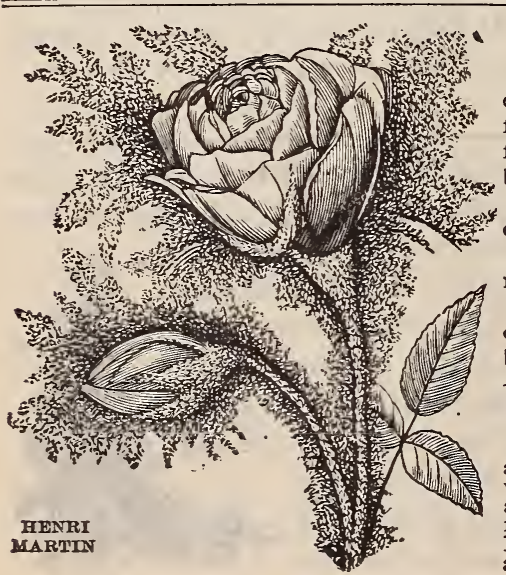

\section{BEAUTIFUL MOSS ROSES.}

Henri Martin-A magnificent Moss Rose, Extra large and perfectly double. Color a deep rosy-carmine, shaded a bright crimson; very mossy and fragrant, and one of the finest. One of the most rampant growing Roses to be found in any class, and a most profuse bloomer in its season. Price, 15c each: large two-year-old plants, 30c each.

Princess Adelaide-Fine bright carmine; large and vigorous; much esteemed. Price, $15 \mathrm{c}$ each; two-year-old plants, $30 \mathrm{c}$.

Elizabeth Rowe-Bright satiny-pink, large, double; fragrant, finely mossed. Price, $15 \mathrm{c}$ each; two-year-old plants, 30c.

Comtesse de Murinais-Flowers white, sometimes tinged with flesh color ; large, double, cupped buds, heavily mossed. One of the best Moss Roses. Price, 15c each; large two-year-old's, 30c each.

The Beautiful Memorial Rose, Rosa Wichuriana

This hardy and lasting Rose creeps over the ground like Ivy. Thr leaves are gloss, dark green, and handsomely notched. The flowers, which are borne very profusely, during July, are large, pure white, single, with yellow center, and have a strong, wild-rose fragrance. It is one of the very best plants for rock work, embankments, slopes, cemeteries, as well as for garden cultivation. Its wonderfully free, rampant habit frequently shows growth of 10 to 12 feet in a season, spreading as it goes. Fine, strong plants, $10 \mathrm{c}$ each; 3 for $25 \mathrm{c}$. 


\section{LARGE TWO.YEAR.0LD TEA ROOSES}

ALL ARE MONTHLY OR EVER=BLOOMING.

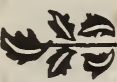

ALL ARE EXTRA LARGE, STRONG, STOCKY, ROBUST PLANTS THAT WILL GROW AND BLOOM AT ONCE.

난

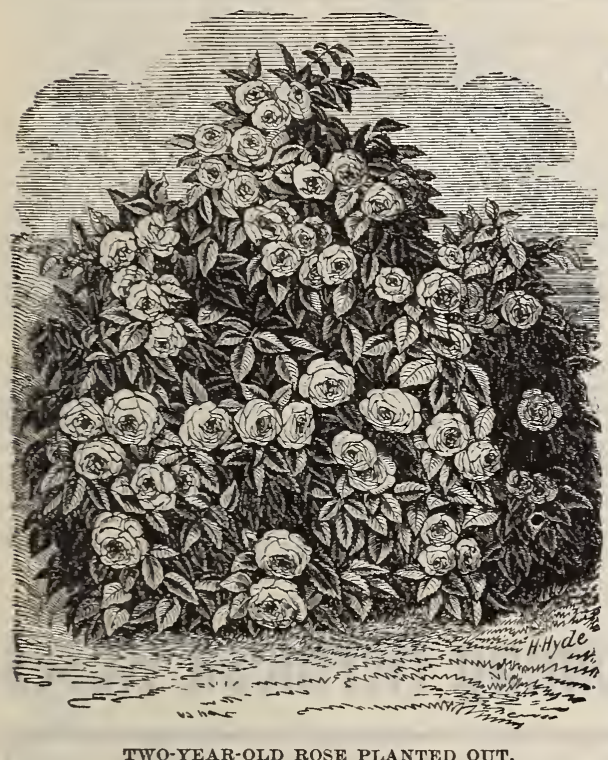

TWO-YEAR-OLD ROSE PLANTED OUT.

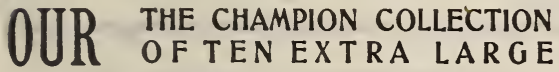

71E MAKE a specialty of growing extra large Two-Year-Old Roses, and we have again for this Spring the largest and finest Two-YearOld Roses in our city. The proof of the pud. ding is in the eating of it. The proof of our assertion is in our ability to supply our customers with the largest, finest, and also cheapest Two-Year-Old Roses in Springfield. Try us for large Roses. $\quad * \quad * \quad * \quad *$ * We know we shall please you. *

\section{SPECIAL}

TWO - YEAR - OLD ROSES FOR ONLY ONE DOLLAR.

$\mathfrak{F}^{\circ}$

ONLY ONE DOLLAR we wi11 send you TEN of our SUPERB, LARGE TWO-YEAR-OLD

ROSES, embracing on1y the very choicest and best everblooming varieties for bedding out, each one priced at $25 \mathrm{c}$ to $40 \mathrm{c}$ each at catalogue rates. The selection must be left to us, and we will send on1y strictly high grade Roses. A11 will be different, and a11 correctly labeled.

\section{THIS COLLECTION OF \\ $\varnothing \varnothing$ TEN BIG ROSES $\varnothing \varnothing$}

must be sent by express. If ordered by mail, a.dd 25 cents extra to help pay the postage.

No further discount on this offer.

OUR IRON-CLAD COLLECTION OF

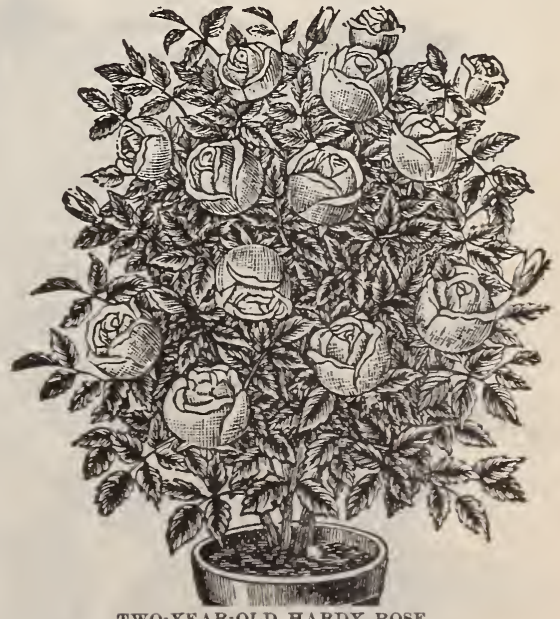

TWO-YEAR-OLD HARDY ROSE.

\section{MAGNIFICENT HARDY HYBRID PERPETUAL ROSES FOR \$1.00.}

This is a grand offer and should be taken advantage of by our patrons who desire a fine assortment of hardy Roses that remain out all Winter and inerease in beauty from year to year. Each one of the eight will be perfectly hardy and include all the best colors FROM PURE WHITE TU DARK CRIMSON.

This Collection must be sent by express. If ordered by mail, add $25 \mathrm{c}$ extra to help pay the postage. 


\section{Five Famous hardy Rambler Roses CRIMSON, PINK, WHITE, YELLOW AND ROSE}

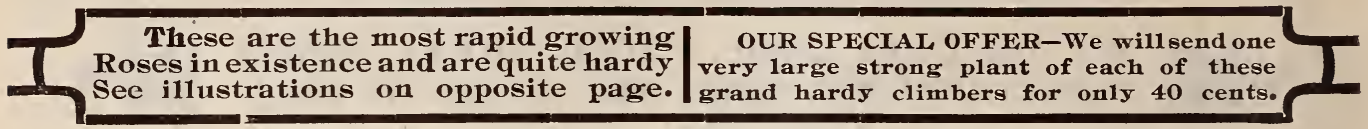

THE YELLOW RAMBLER, Aglaia.

This promises to supply that "long-felt want," a double yel.ow, hardy climbing Rose, a thing which has been sought after the world over. Related to Crimson Rambler, and, like it, blooms in large trusses, often bearing from 120 to $15 \mathrm{~J}$ flowers in a cluster, lasting three or four weeks without fading. Very popular. Price, $10 \mathrm{c}$ each; very large two-year-old size, $30 \mathrm{c}$ each.

THE WHITE RAMBLER, Thalia.

This charming new Rose of the Rambler variety is a wonder. It climbs rapidly; is entirely hardy; produces immense clusters of pure white Roses. Perfectly double, of delight1 ul fragrance and of an immaculate white. The best white Climbing Rose extant. Price, $10 \mathrm{c}$ each; very large two-year-old size, $30 \mathrm{c}$ each.

New Climbing Rose, CRIMSON RAMBLER.

The plant is of vigorous growth, making shoots from eight to ten feet during the season, rendering it a charming pillar Rose. It is also magnificent in bush form, and for covering Rose. It is also magnificent in cannot be excelled. One of the striking characteristics of this Rose is its remarkable color, which is of the bright est crimson, which remains undimmed to the end. The flowers are produced in great pyramidal panicles or trusses, each carrying from thirty to forty blooms, the individual flowers measuring from 1 to $1 \frac{1}{2}$ inches in diam- eter, and remaining perfect on the plant for upwards of two weeks. It is exceedingly hardy, having successfully withstood the test in exposed situations of two very severe Winters. Hardy in every latitude yet tried as far north as the lakes. Price, 10c each; very large two-year-old size, $35 \mathrm{c} \mathrm{each}$.

\section{THE PINK RAMBLER, Euphrosyne.}

This fine, hardy, climbing Rose is very vigorous, and easily reaches a height of 25 to 36 feet. The flowers are borne in clusters, as many as 60 being frequently found in a cluster; they are deep pink, quite full and exceedingly fragrant. We consider it one of the very best hardy climbing Roses, and it may be well called "Pink Rambler." Price, 10c each; very large two-year-old size, $30 \mathrm{c}$ each.

PSYCHE, Tho New Rambler Rose.

Received the award of merit of the Royal Horticultural Society of England. A cross between Crimson Rambler and the Polyantha Rose, Golden Fairy. In growth and habit it much resembles the Crimson Rambler. The flowers are produced in clusters of eight to thirty-flve and are two to two and a half inches across when fully expanded. The color is white, suffused with salmon rose and pink, with yellow base to the suffused with salmon rose and pink, with yellow base to the
petals. A real companion to Crimson Rambler. The horticultural press of England gives it very flattering comment as described at the various exhibitions. Price, $20 \mathrm{c}$ each; large two-year-old plants, $35 \mathrm{c}$ each.

\section{Che Four Gardy Ever=blooming Germosa Roses}

We offer four of the Hermosa type of Roses. If you want to have rosebuds to cut all Summer, this set will give yon an abundance.

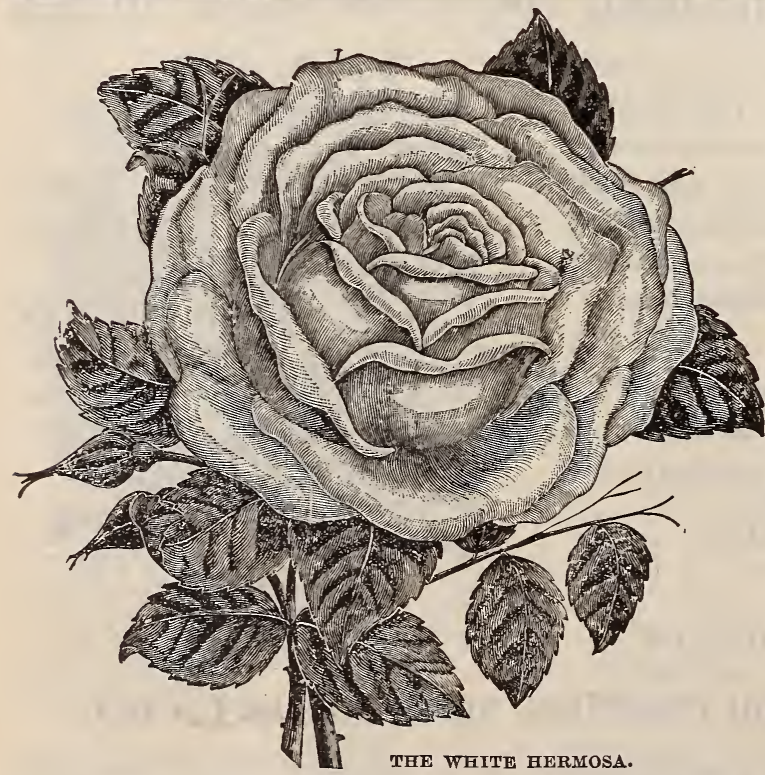

YELLOW HERMOSA, Coquet de LyOn.

This is a most charming yellow Tea Rose, a grand grower, has elegant buds, and is so free in flower as to be called the Yellow Hermosa. This is the best blooming pure yellow Rose in our catalogue. It is a Rose that will please all. Price, 10 cents each; large two-yearc old plants, $30 \mathrm{c}$ each.

CRIMSON HERMOSA, Queen's Scarlet.

This is, without doubt, the very best of all red Roses for bedding. It can be planted anywhere, being entirely hardy. The flowers are of large size and of a fiery scarlet, a color seldom seen in Roses. Indeed, a bed of this Rose produces a mass of red equal to a bed of Geraniums. It is planted everywhere on account of its color and freedom of bloom. None better. Try it. Price. 10c each; large two-year-old plants, $30 \mathrm{c}$ each.

\section{WHITE HERMOSA, Marie Lambert.}

Pure white. It has been called the White Hermosa, as it resembles Hermosa in form and freedom of bloom, and is quite as valuable; for, though no claim has been made for it as a fancy Rose, its persistence in bloom will make it a very popular white variety for bedding or for pots. This Rose is fast becoming very popular, as there is no better white Rose. It is the finest blooming white Rose we offer. Price, $10 \mathrm{c}$ each; large two-yearold plants, $30 \mathrm{c}$ each.

\section{PINK HERMOSA, The Old Favorite.}

Everybody knows this famous variety. As hardy as an oak, and always covered with its elegant clear pink blooms. There is no shade of color of any kind to mar its purity. We doubt if any Rose ever grown will take its place. Price, 10c each; large two-year-old plants, $30 \mathrm{c}$ each. 


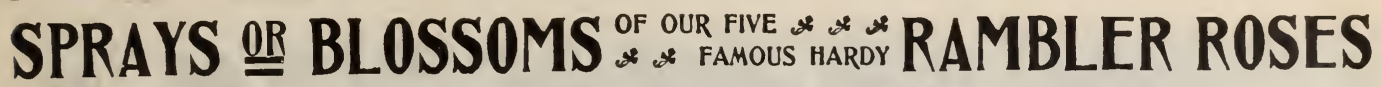
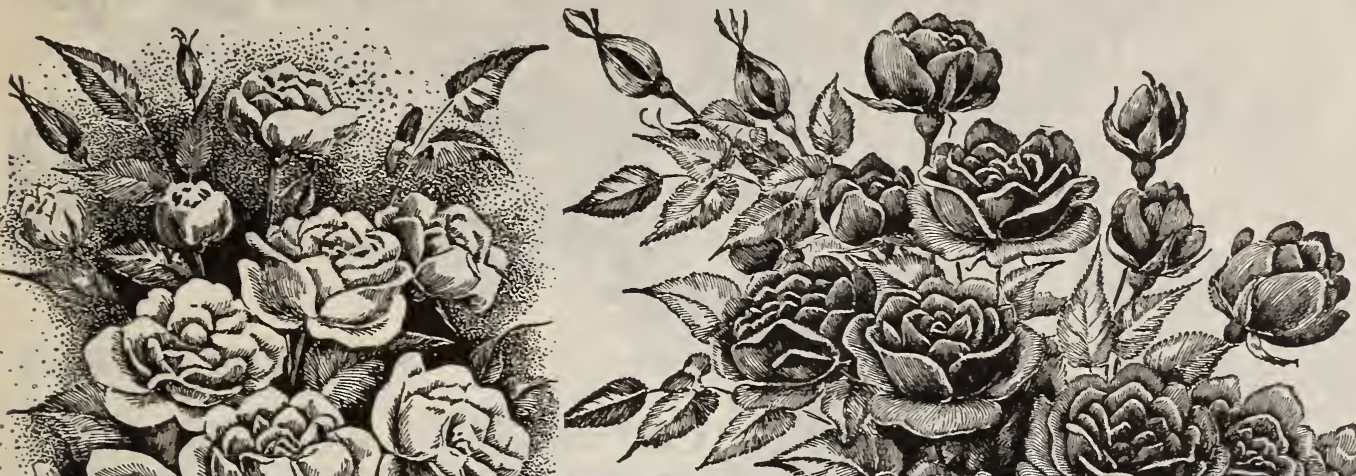

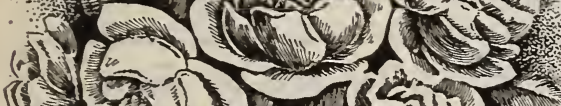

(f)

S

(3)

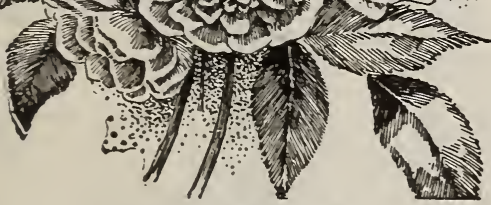

SPRAY OF WHITE RAMBLER.

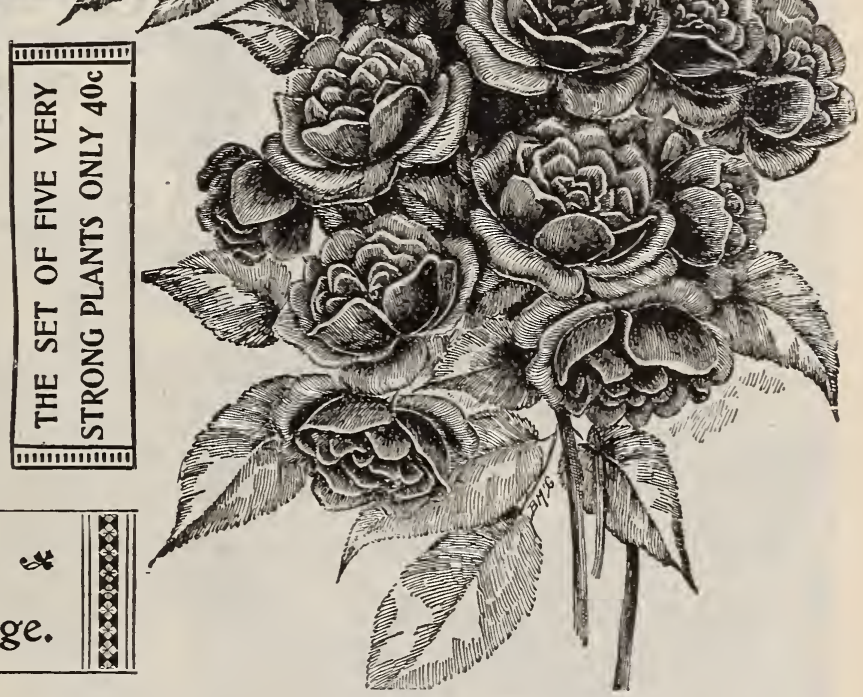

For Description * * * * See opposite page.

SPRAY OF YELLOW RAMBLER.

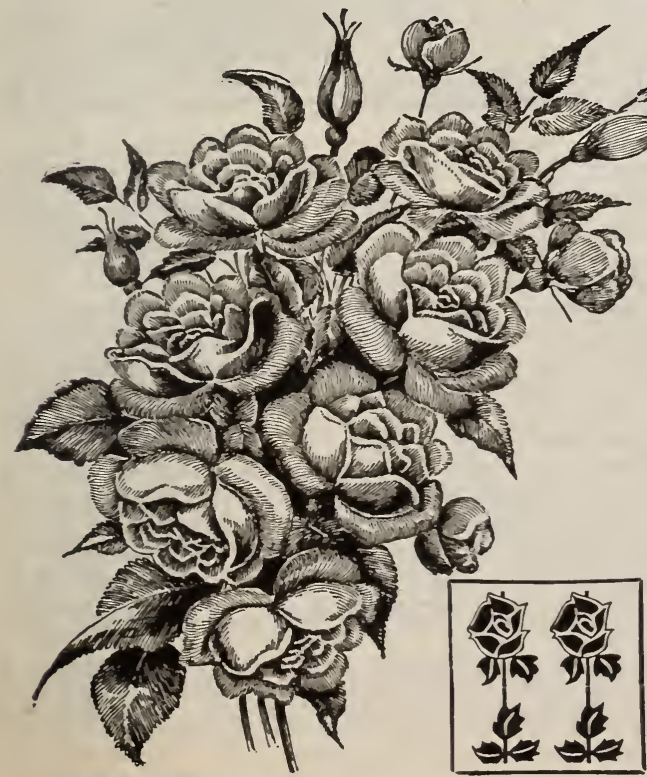

SPRAY OF PSYCHE.

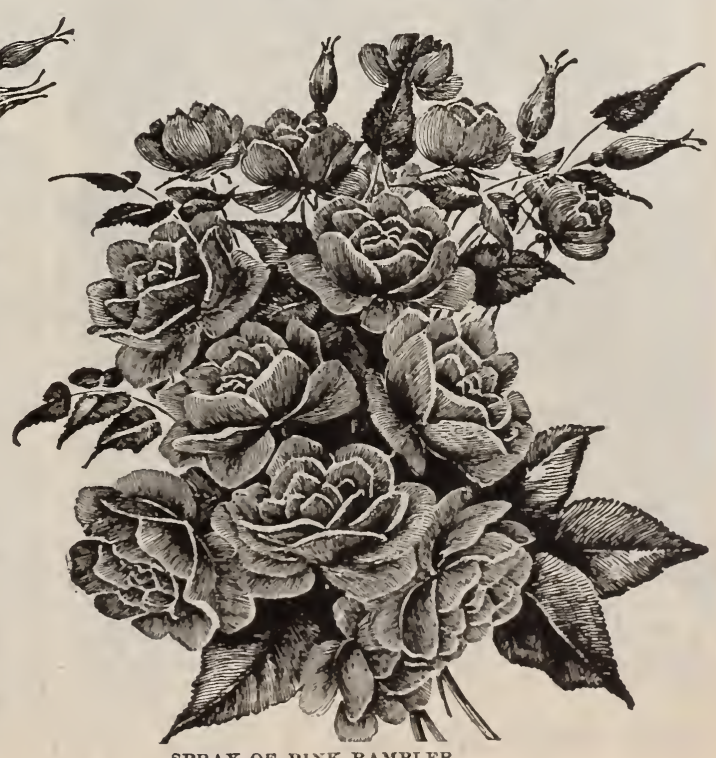



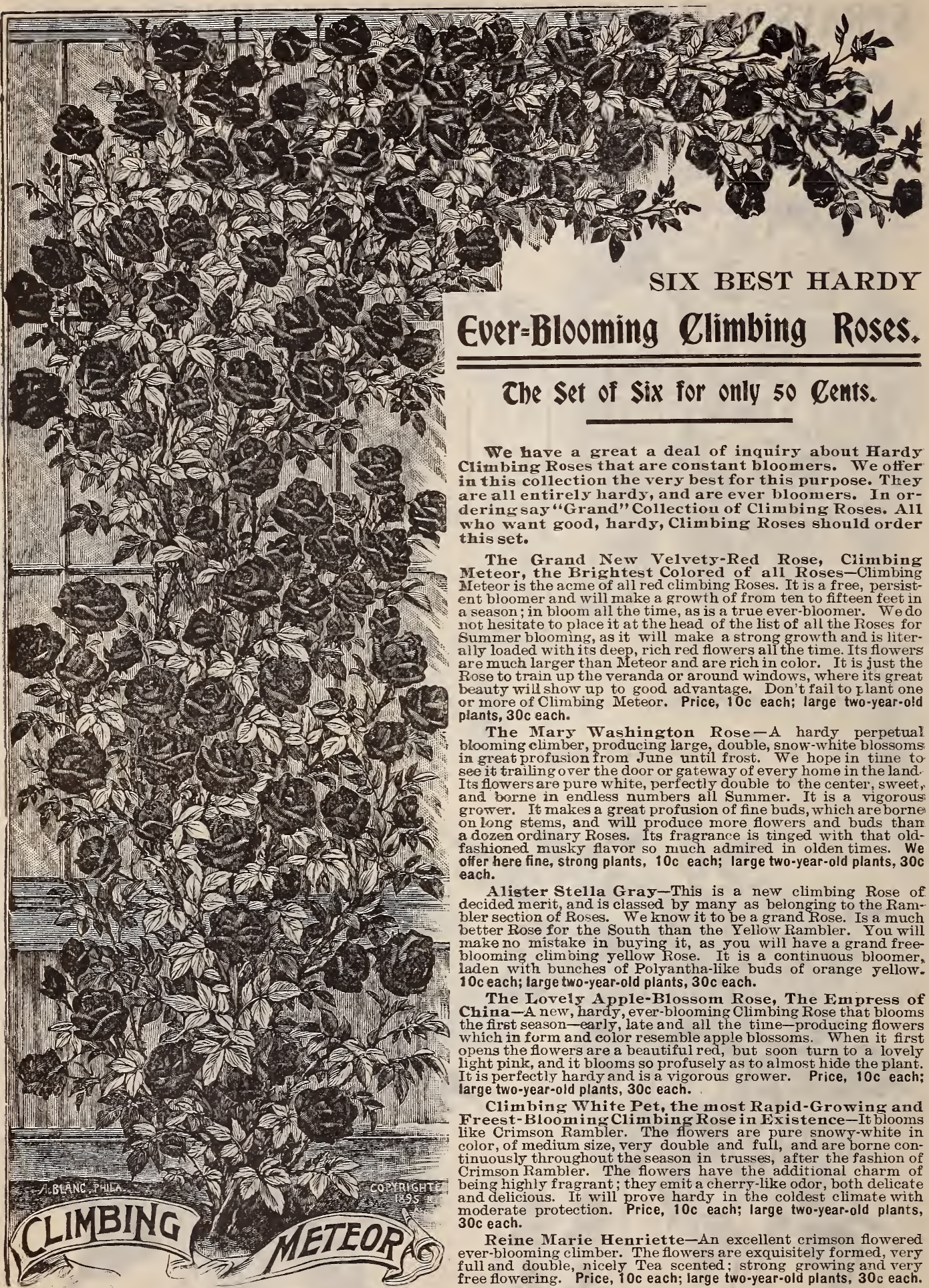

Che set of six for only 50 lents.

We have a great a deal of inquiry about Hardy Climbing Roses that are constant bloomers. We offer in this collection the very best for this purpose. They are all entirely hardy, and are ever bloomers. In orderingsay "Grand" Collectiou of Climbing Roses. All who want good, hardy, Climbing Roses should order this set.

The Grand New Velvety-Red Rose, Climbing Meteor, the Brightest Colored of all Roses-Climbing Ireteor is the acme of all red climbing Roses. It is a free, persistent bloomer and will make a growth of from ten to fifteen feet in a season; in bloom all the time, as is a true ever-bloomer. We do Summer blooming, as it will make a strong growth and is literally loaded with its deep, rich red flowers all the time. Its flowers are much larger than Meteor and are rich in color. It is just the Rose to train up the veranda or around windows, where its great beauty will show up to good advantage. Don't fail to plant one or more of Climbing Meteor. Price, $10 \mathrm{c}$ each; large two-year-0!d plants, $30 \mathrm{c}$ each.

The Mary Washington Rose-A hardy perpetual bloming climber, producing large double snow-white blossoms in great profusion from June until frost, We hope in tiune to see it trailing ver the door or gateway of every home in the land. Its flowers are pure white, perfectly double to the center, sweet, and borne in endless numbers all Summer. It is a vigorous it makes a great profusion of fine buds, which are borne ang stems, and will produce more flowers and buds than fasen ordinary Roses. Its fragran in inged with that oldoffer here fine, strong plants, $10 \mathrm{c}$ each; large two-year-old plants, $30 \mathrm{c}$ each.

Alister Stella Gray-This is a new climbing Rose of decided merit, and is classed by many as belonging to the Rambler section of Roses. We know it to be a grand Rose. Is a much better Rose for the South than the Yellow Rambler. You will make no mistake in buying it, as you will have a grand freeblooming climbing yellow Rose. It is a continuous bloomer, $10 \mathrm{c}$ each; large two-year-old plants, $30 \mathrm{c}$ each.

The Lovely Apple-Blossom Rose, The Empress of China-A new, hardy, ever-blooming Climbing Rose that blooms the first season-early, late and all the time-producing flowers which in form and color resemble apple blossoms. When it first opens the flowers are a beautiful red, but soon turn to a lovely pink, and it blooms so profusely as to almost hide the plant. large two-year-old plants, $30 \mathrm{c}$ each.

Climbing White Pet, the most Rapid-Growing and Freest-Blooming Climbing Rose in Existence-It blooms like Crimson Rambler. The flowers are pure snowy-white in color, of medium size, very double and full, and are borne continuously throughout the season in trusses, after the fashion of Crimson Rambler. The flowers have the additional charm of being highls fragrant; they emit a cherry-like odor, both delicate and delicious. It will prove hardy in the coldest climate with moderate protection. Price, 10c each; large two-year-old plants, $30 \mathrm{c}$ each.

Reine Marie Henriette-An excellent crimson flowered imber. The flowers are exquisitely formed, very full and double, nicely Tea scented; strong growing and very
free flowering. Price, $10 \mathrm{c}$ each; large two-year-0ld plants, $30 \mathrm{c}$ each.

THE SET OF SIX LARGE TWO-YEAR-OLD PLANTS FOR \$1.50. 


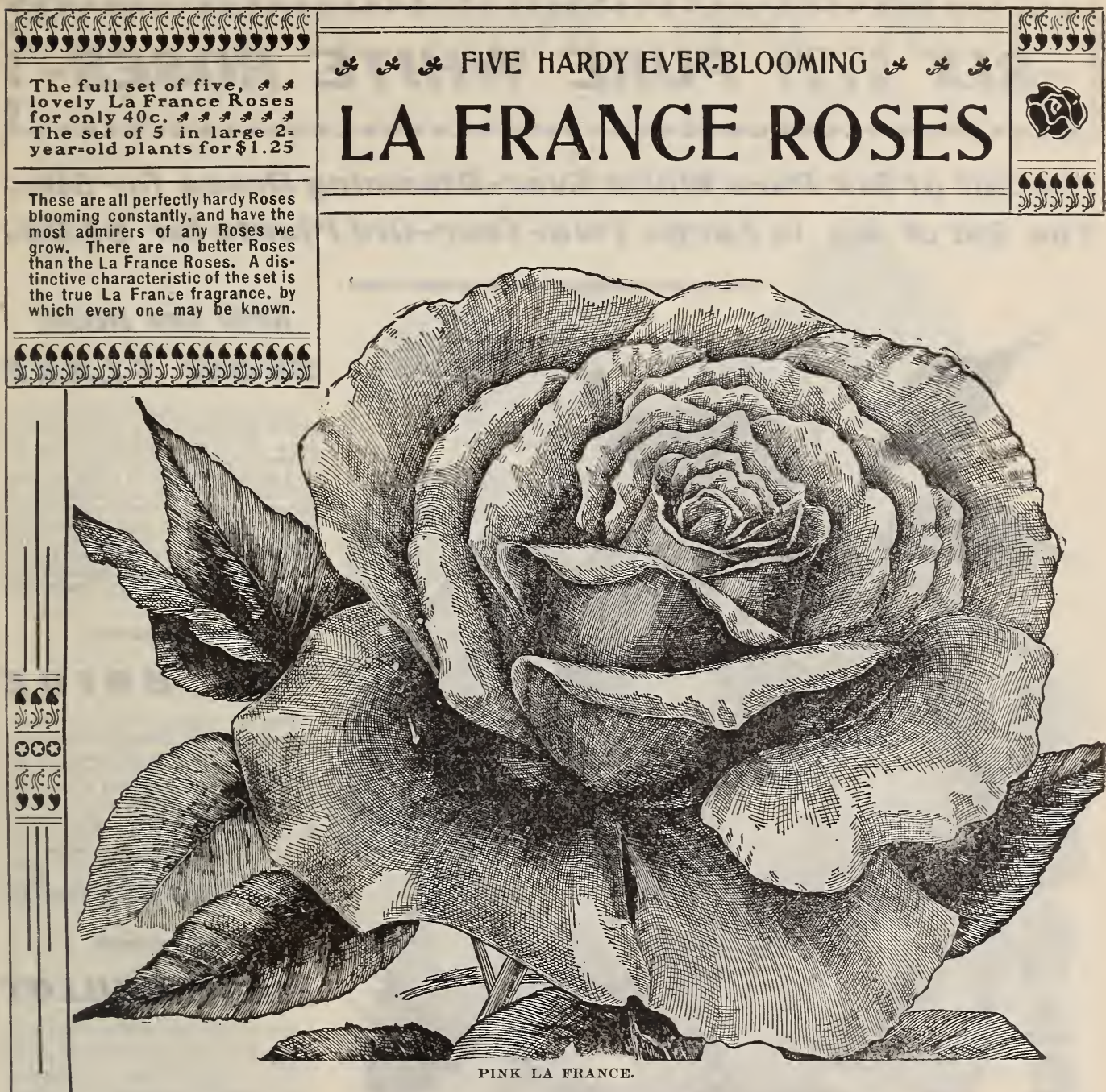

PINK LA FRANCE It is of superb form, and double as a = Rose can be. No variety can surpass it in delicate coloring-silvers-rose shades with pink. It has a satin sheen over all its petals. It is most univers. ally regarded as the most useful of Roses, for it is hardy beyond question. It blooms continuously. The flower is large, finely built, endures for a great length of time, is exquisitely corred and fragrant in the highest degree. Price, 10c; large size, 30c.

W'HITE LA FRANCE (Augustin Guinnoiseau) Here we $=$ have a beauty indeed; one we c:n recommend to all, whether for outdoor culture or for pots in the house in Winter. It is identical with La France except in color. It is pearls white, sometimes tinted with fawn. Price $10 \mathrm{c}$ each; large 2-year-old size, 30c. THE RED LA FRANCE (Duchess of Albany) We have no hesitancy in saying to our eustomers that this rose stands at the head of all Roses, not excepting La France. What we wish to impress is the fact that as a Rose for all purposes, it has no peer. It is identical with La France, excepting in three points. Those are: A more vigorous growth, a large and more expanded flower, and a deep, even pink in color; not shaded, but what is called a solid color. Price, $10 \mathrm{c}$ each; large 2-year-old size, $30 \mathrm{c}$.

YELLOW LAFRANCE (Madame Pernet Ducher) A charming Rose; a new shade in this section, being the first with a distinct jellow colored bud. The outside jetals are sulphur-yellow and assume a darker shade toward the center. The open flower is very graceful and holds well together. It is an ivory-white in color, with a polished, glistening surface like a water lil5. Price, $15 \mathrm{c}$ each; large 2 -year-old plants, $40 \mathrm{c}$ each.

STRIPED LA FRANCE (Madame Angelique Veysset) The Striped LaFrance combines all the good qualities of a La France in growth, fragrance, shape of bud and flower; in fact, differs not from it except in color. It is nicely striped, the marking being plain and distinct, the variegation a beautiful bright Rose on a satin-pink ground. Price, $10 \mathrm{c}$ each; large 2-year-old size, $30 \mathrm{c}$. 
DIX OP THE PURE WHITE ROSES-

\section{The Set of Six Pure White Ever-Blooming Roses for 50G.} The Set of Six in Large Two-Year-OId Plants for \$1.25.

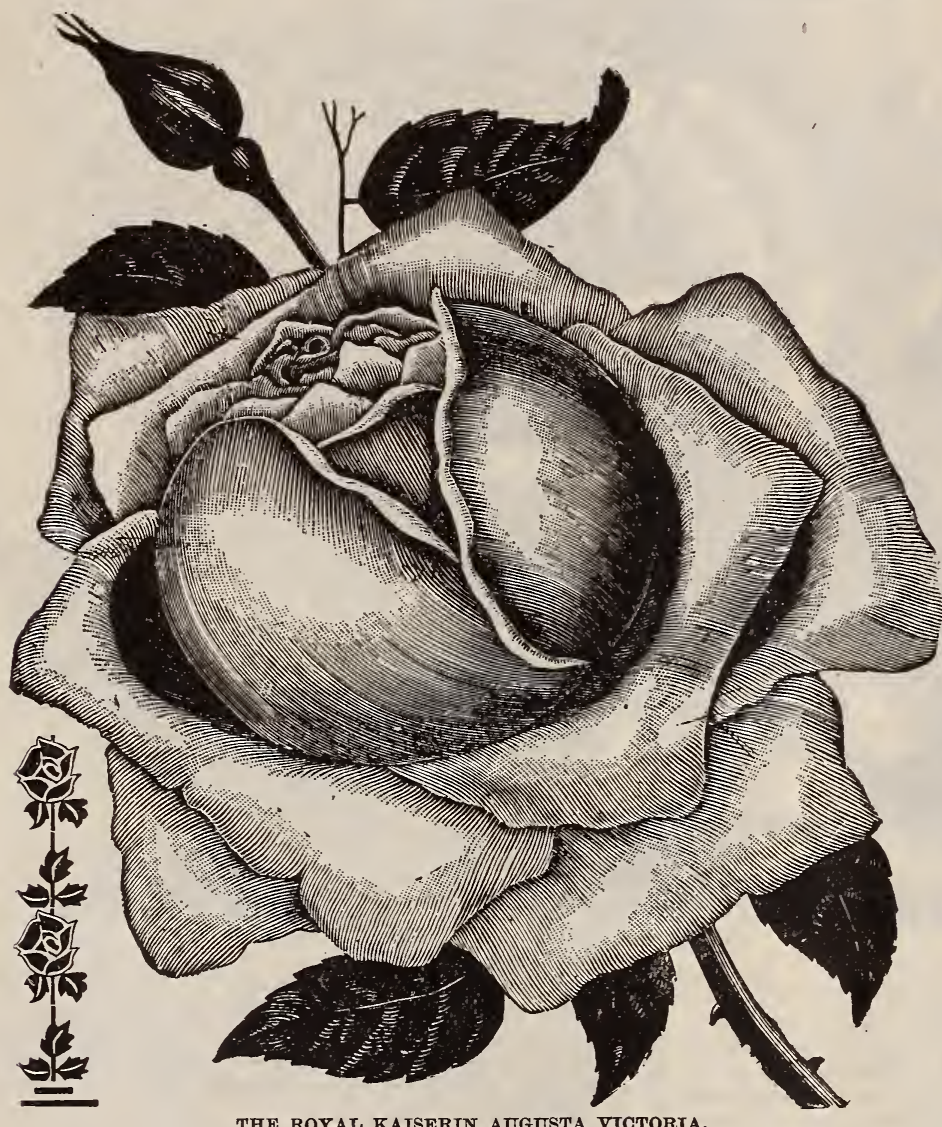

NEW TEA ROSE,
SNOW FLA KE

It is a lovely new white Tea-the freest flowering Rose we have ever seen. The Rose was introduced by C. Strauss \& Co., Washington, D. C., and by them grown in large quantities for cut flowers, they claiming it the most profitable white Rose they grow; that they had counted 153 buds and flowers on one plant in $\mathbf{a}$ bingle day, and the plant less than a year old. Nice young plants of this novelty for $10 \mathrm{c}$ each; large plants $25 \mathrm{c}$ each.

\section{THE BRIDE}

This is undoubtedly the finest white Rose ever offered to the public, and we take great pleasure in recommending it to all our customers. It is a Rose that supplies a long-felt want. A few of the white, everblooming Roses now in commerce have beautiful double flowers, but none of them compare with The Bride in the size and shape of buds and half expanded flowers. Price, $10 \mathrm{c} \mathrm{each}$; large two-year-old plants, $26 \mathrm{c}$ each.

\section{MARIE GUILLOT}

Weconsider this variety the equal, if not the peer, of any Rose of its color in cultivation. A trial will convince any one that this endorsement is not extravagant. The flow. ers are full and extra large, very double and sweetly scented; has many rivals, but no equals for open many rivals, but no equals for open large two-year-old plants, $25 \mathrm{c}$ each.

\section{NEW PURE WHITE ROYAL TEA ROSE KAISERIN AUGUSTA VIGTORIA}

\section{The Best White Rose in the World.}

This beautiful Rose has not only a royal name, but is a royal Rose as well. We have white Roses that have elegant buds, but when full blown are not all that is desired. Then again we have white Roses that are elegant when full blown, but have poor buds. This Rose combines both these good qualities. It is a continuous bloomer producing successive crops of buds, and formed with large $p$ tals of best substance; shows no center when fully open; color, pure creamy-white. It far surpasses any other white Rose in all particulars, and has a much richer perfume. Price. 10c each; large two-year-old plants, $30 \mathrm{c}$ each.
THE BEAUTIFUL NEW WHITE TEA ROSE

\section{WHITE MAMAN GOGHET}

The finest Rose of the year. Iike its parent, the growth is vigorous. with rich, healthy foliage, producing large, fine flowers of the purest white; in fact, it is an exact counterpart of the beautiful Maman Cochet, and all who have tried it pronounce it the finest bedding Tea Rose in existence. We would advise all who love choice Roses to plant at least one of this beautiful new Rose. Price, 10c each; large two-year-old plants, 25c each.

\section{THE QUEEN.}

It is a pure snow white, makes good, fine formed buds; is quite full, showing the center but slightly when fully open. The petals are thick and of good substance. Price, 10c each; large two-year-old plants, 25c each. 


\section{Six Best Dark Red Roses.}

THE SET OF SIX RICH RED ROSES IN STRONG PLANTS FOR ONLY 50c. THE SET OF SIX IN LARGE TWO-YEAR-OLD PLANTS FOR \$1.25.

\section{SCARLET BEDDER}

This is, without doubt, the very best of all red Roses for bedding. It can be planted anywhere, being entirely hardy. Flowers are large size, fiery scarlet, a color rarely seen in Roses. Planted everywhere on account of its color and freedom of bloom. Price, $10 \mathrm{c}$ each; large two-year-old plants, $25 \mathrm{c}$ each.

\section{THE METEOR}

A velvety-red ever-bloomer of the deepest glowing crimson, as fine as a Hybrid. Flowers are of a medium size, very double and slightly recurving. A beautiful open Rose, a free bloomer, and a very excellent pot Rose. Has no tinge of violet or purple to mar its beauty. A vigorous, bushy grower, with healthy, bright foliage of the deepest green. Unquestionably the best dark velvety-red Rose yet produced. Grand, both in bud and flower. Price, $10 \mathrm{c}$ each; large twoyear-old plants, $25 \mathrm{c}$ each.

\section{PAPA GONTIER}

A grand red Tea of fine crimson shade and silken texture (as distinct from velvety texture.) The bud is fine size and graceful in form. Extremely free, both in growth and bloom. Very long and beautifully leaved stems can be cut, the foliage being rery dark, heary. One of the best and a] perfect bədder. Price, $10 \mathrm{c}$ each; large two-year-old plants, 25c each.

New Crimson Rose, PRINCESS SAGAN

The flowers of this variety are the richest crimson of any Rose in our vast collection. A single bud or blossom will catch the eye at a great distance, so brilliant is the color. Indeed, it is unmatched in its velvety richness; could well be termed "The Velvet Rose." It is as free in blooming as Bon Silene. Price. $10 \mathrm{c}$ each; large two-year-old plants, $25 \mathrm{c}$ each.

\section{The Lovely New Red Rose, BALD IVIN}

One of the most remarkable Roses of recent date, as strong growing as the best of the Hrbrid Perpetuals, with large, handsome foliage, flowers of the fullest form and largest size, which is equaled in profusion by no other Rose of its size that we have seen. The color is bright, glowing carmine. The bud is long and elegantly pointed. It is as sweet as a June Rose. Frice, $15 \mathrm{c}$ each; large two-year-old plants, 30c.

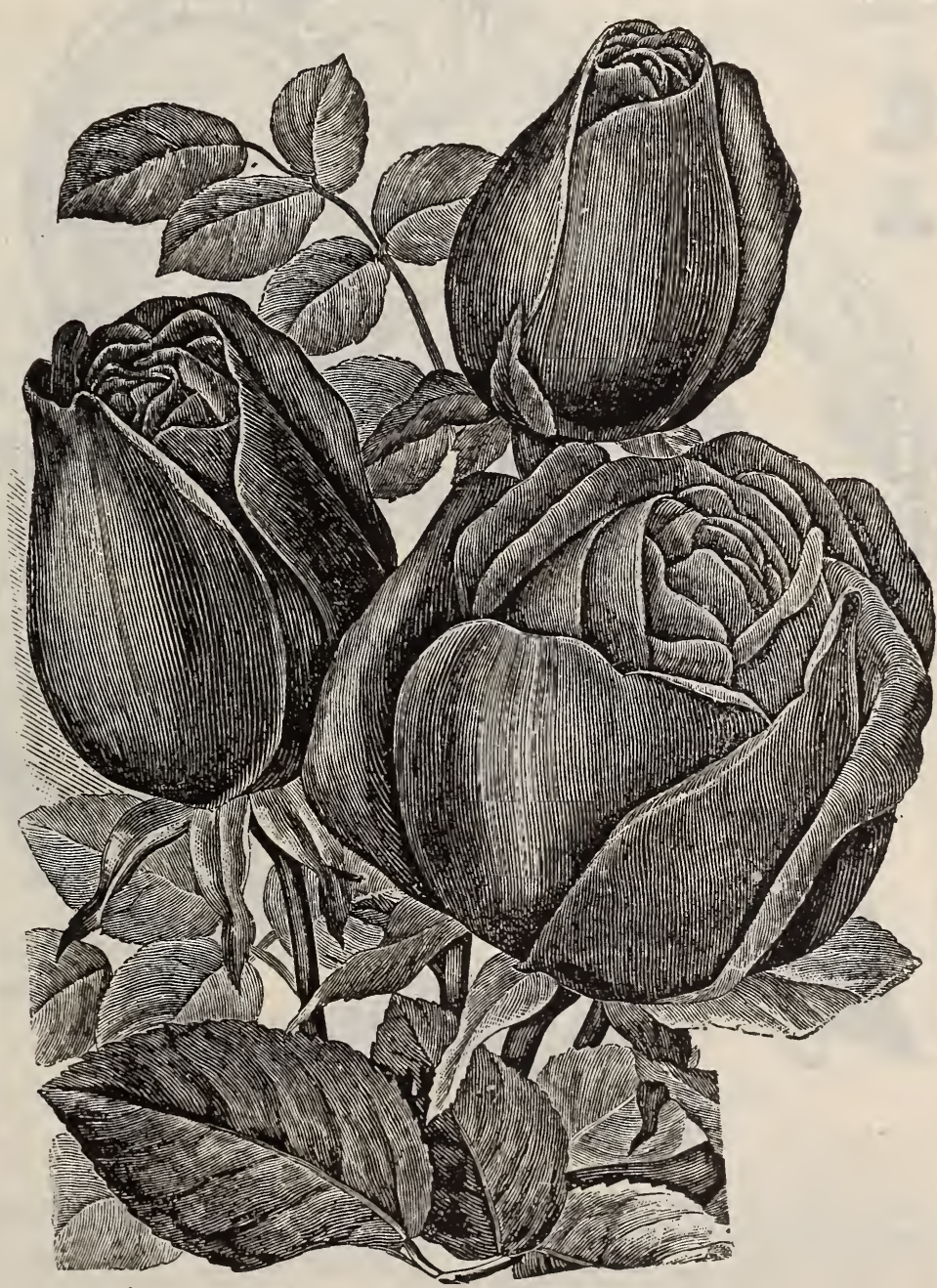

THE BEAUTIFUL BALDWIN.

The Grand New Bedding Rose, GRUSS A TEPLITZ

As a bedding Rose this is one of the finest and most useful varieties ever sent out. The color is brightest scarlet, shading to deep, rich, velvety-crimson. It is very fragrant. The freest grower and the most profuse of any ever-bloomer. The mass of color produced is wonderful, and the foliage is extremely beautiful, all the younger growth being a bronzy plum color. A queen among scarlet bedders. It is a perfect sheet of richest crimson scarlet all Summer. Price, $15 \mathrm{c} \mathrm{each:}$ large two-year-old plants, $30 \mathrm{c}$ each. 


\section{SIX BEST GOLDEN YELLOW ROSES}

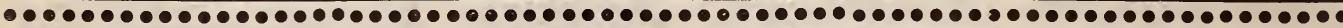

THESE ARE THE BEST OF ALL DEEP YELLOW ROSES AND ARE ALL STRONG GROWERS AND PROFUSE BLOOMERS.

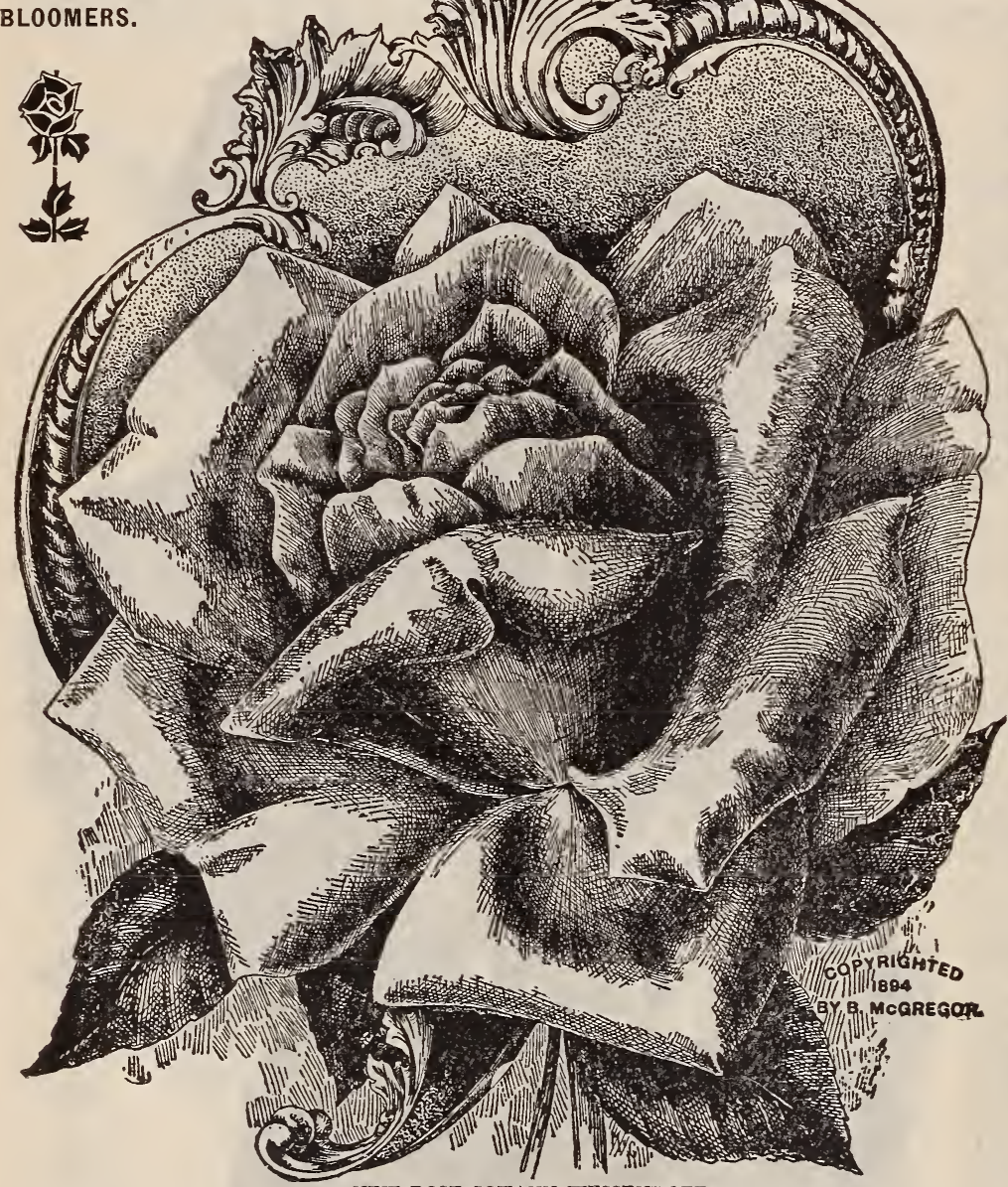

NEW ROSE JOHANN WESSENHOFE.
S(x)

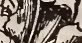

(2)
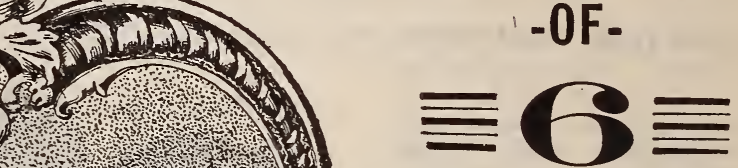

SPLENDID

SORTS FOR

$50 \mathrm{c}$

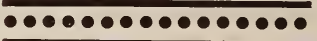

ANY THREE

$-F 0 R-$

- ค・・・・・・・・・・

THE SET OF

6 LARGE 2-

YEAR - OLD

PLANTS FOR

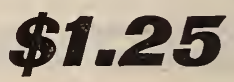

THE BEAUTIFUL NEW ROSE-Johann Wessenhoff. This is the finest grand bedding yellow Rose. It is a deep, golden-yellow, and is such a good bedding Rose that it is already called by some the Bedding Perle. It is certainly fine. Price, $15 \mathrm{c}$ each; large two-year-old plants, $35 \mathrm{c}$ each.

THE COPPERY YELLOW ROSE-M11e. Franciska Kruger. The striking color of this handsome Rose placesit at once in the front as a bud producer in the open air. It is closely allied to Catherine Mermet, and resembles it in everything save color. In its shading of deep copperyyellow it stands unique and distinct from all others. Price, $10 \mathrm{c}$ each; large two-year-old size, $25 \mathrm{c}$ each.

THE DEEP GOLDEN YELLOW ROSE-M11e. Cecile Berthod. Most beautiful, both in bud and flower, which is deep golden vellow. In fact, the deepest yellow in color of any Rose we grow. The foliage is very bright. This is a Rose of magnificent size and color. Altogether a grand Rose and always in bloom. Price, $10 \mathrm{c}$ each; large two-year-old plants, 30c each.
THE GRAND BEDDING YELLOW ROSE-Star of Lyon, Etoile de Lyon-This magnificent Tea Rose is a rich golden-yellow; a strong, healthy and vigorous grower; immense bloomer, bearing flowers and buds early and late. The flowers are very deep, rich and full; excellent substance, very sweet Surely on of the best and most beautiful yellow Tea Roses for general planting ever introduced. Remarkably hardy, both as to heat and cold, frequently standing the Winters here uninjured in open ground without protection, and blooming nicely all through the hottest part of the Sum. mer. Price, 10c each; large two-year-old plants, 25c each.

THE OUEEN OF YELLOW ROSES-Pearl of the Grardens. No yellow Rose in cultivation can equal this in its profusion of deep golden-yellow Roses. The only rival of Marechal Niel. Price, 10c each; large two-year-olJ size. $25 \mathrm{c}$ each.

THE PROFUSE BLOOMING YELLOW ROSECoquet te de Lyon. Vigorous, rapid grower and constant bloomer. Pure canary yellow. $10 \mathrm{c}$ each; two-year-old, 25c,

If you are desirous of having yellow Roses we would advise you to plant the Roses named on this page. They are all well-known varieties, and every one has merits of its own entirely distinct from one another. $* * * * * * *$ 


\section{A Page of Famous New Roses}

\section{THE BEST OF THE LAST TWO YEARS INTRODUCTIONS. *}

SPECIA L OFF E R-We will send any four of these new Roses for 50
cents, or the entire set of $18 \mathrm{Grand}$ New Roses on this page for $\$ 2.00$. Any
four in large two-year-old plants for $\$ 1.00$. No further discount.

WHITE LADY. (Hybrid Tea.)

One of the startling new Roses of recent date. It has gigantic flowers with enormous magnolia-like petals; one of handsomest and most effective of Roses, and very distinct. The color is white, delicately flushed with pale pink; blooms are borne in great profusion on stiff stems, with heavy foliage. Longer stems would rank this with Americun Beauty, but we recommend it to every rose-forcer for trial. In our local trade busers hare been carried away with its beauty, and are willing to pay a good price for the blooms. In England, the past jear, it took first prize at the Chrystal Palace show for twelve blooms of any white Rose over The Bride, Bessie Brown, and others. Price, $20 \mathrm{c}$ each; two-year-plants, $40 \mathrm{c}$ each.

\section{GLADYS HARKNESS. (HYBRID TEA.)}

Growth very erect and vigorous, reminding one of American Beauty; profuse in bloom, flowers large, formed like a fine H. P.; color deep salmon-pink; has a splendid constitution and is very fragrant. Price, $20 \mathrm{c}$ each; two-yearold plants $40 \mathrm{c}$.

\section{JULES GIRODIT. (Hybrid Tea.)}

Flowers very large and of good form. Rosy peach color shading to bright pink ; very free. Magnificent in size and form. Price, $20 \mathrm{c}$ each; large size, 40c each.

\section{BUNEL. (Hybrid Tea.)}

Flowers large, quite full, composed of very large outer petals diminishing in size toward the center; the open rose is of beautiful form, imbricated, and of rosy peach color shading to pale gold, bordered with bright rose. Price, 20c each; large size, $40 \mathrm{c}$.

\section{RED HERMOSA. (Bengal.)}

A seedling of Hermosa-Reine Marie Henriette; it is posessed of the vigor and other good qualities of Hermosa; with deeper green glossy foliage. and beautiful dark carmine-red deeper green, glossy foliage; and beautiful dark carmine-red fariety and will certainly become very popular, as it cannot fail of proving useful. Price, 20c; large size, $40 \mathrm{c}$.

\section{MARIE LOUISE POIRET. (Hybrid Tea.)}

Bud long and pointed, flower very large; full and of splendid texture, the petals are large, outer edges fresh rose, center darker; rery free; a seedling of Caroline Testout; Marguise Litta. Price, $20 \mathrm{c}$ each; large size, $40 \mathrm{c}$.

\section{MME. LUCILE COULSON.}

Rosy-flesh color, shading to pink and copper-yellow flower of medium size, full, and nicely formed. A beautifu variety, seeled from Kaiserina Augusta Victoria x Luciole. This grand new Rose is without doubt the richest and most highly colored Rose in the world. There is nothing like it in our vast collection. Price, strong plants, $15 \mathrm{c}$ each; two-year-old plants, 25c.

\section{LADY CLANMORRIS. (Hybrid Tea.)}

Perfectly distinct; a splendid rose, of very robust growth and free branching habit, flowering continuously and freely throughout the season; blooms very large and of good form, petal large, smooth and of great substance; creamywhite with delicate salmon-certer, edge of the petals margined pink. Price, 20c each; large size, 40c.

\section{BEATRIX DE BUISSERET. (Hybrid Tea.)}

Bud extraordinarily beautiful; flower rery large, quite full, of beautiful form and perfect texture; silvery rose and rosy-carmine; very free and fragrant. A seedling from Mad. Caroline Testout. Price, $20 \mathrm{c}$ each; large size, $40 \mathrm{c}$.

\section{ROSOMANE GRAVEREAUX. (Hybrid Tea.)}

This variety is of the general style of Pres. Carnot, with an enormous long bud, producing a rery large, very double, open flower carried on a long, stiff stem; the petals are very large; color, silvery white, with rererse of rosy flesh; very fragrant and very free. Price, $20 \mathrm{c}$ each; large size, $40 \mathrm{c}$.

\section{GRAND NEW ROSE FRANCO RUSSIA.}

A new Ruse of exquisite kind and color, ranked by many enthusiasts as the best yellow Tea Rose. The flowers are of large size, perfectly double to the center and perfect in shape both in bud and blossom. The color is magnificent-deep rich lemon yellow with creamy yellow center with tints of sulphur. It is beautiful beyond description. A strong $15 \mathrm{c}$ each; two-year-old plants $30 \mathrm{c}$.

\section{MARQUIS LITTA. (Hybrid Tea.)}

This is a new French Rose, and is by all odds the very best new Rose that has been introduced in years. It resembles in color American Beauty. Buds and flowers of the largest size. It is a strong, vigorous grower, producing its handsome buds and flowers on long stems. It forces equal to Bride or Bridesmaid. Never comes "off color" or with misshaped buds. This is the nearest approach to the ideal forcing Rose. Don't fail to try this grand variety. 20c each; large two-year-old plants, $40 \mathrm{c}$

\section{SUNRISE}

\section{A BEAUTIFUL NEW EVER-BLOOMING TEA ROSE.}

SURRISE is the most gorgeous Rose of its class ret intro. duced. This has made a sensation in England and has taken first honors wherever shown. In, 'ose bud form it shows the high, brilliant colors seen only in the Austrian Copper. scar let and jellow. As it opens the color deepens, the scarlet turning darker red, the yellow to orange and copper, the in. side of the petal golden-yellow. The open Rose is large, perfectly double and of grand form. The foliage is glossy and thick, the new growths being the darkest and most beautifu found among Roses. The form and color of bud, its freedom of growth and bloom will give Sunrise a high place among Roses. Price, $15 \mathrm{c}$ each; large two-year-old plants, $30 \mathrm{c}$.

\section{NEW HYBRID TEA ROSE, "LIBERTY."}

One of the most sensational Roses ever introduced. The color is crimson scarlet, after the style of Meteor, but more brilliant. This variety has created a furor from ocean to ocean, and wherever exhibited has won first honors. The flowers are perfectly formed, being full, deep and double; very fragrant. This variety has the distinction of being the most costly Rose now known, the price of the original plants having been stated at $\$ 700.00$. Magnificent in every way. $20 \mathrm{c}$ each; two-year-old plants, $40 \mathrm{c}$.

\section{THE SPLENDID NEW TEA ROSE, MRS. ROBERT GARRETT.}

A beautiful large Rose of exquisite shape, finish and blending of colors. The flowers are large, on strong stems clothed with heary foliage. The buds are long and pointed in shape, and open up beautifully into a full, rounded flower. Color, a glowing shell pink, rery deep in the center; the fragrance is delicate and pleasing. Price, 10c; two-year-old plants, 25 c each.

\section{SOUV. DE ROSE TERREL.}

Flower yellowish white with aurora and carmine shadings large and full; plant strong growing and free blooming. $20 \mathrm{c}$ each; two-year-old plants, $40 \mathrm{c}$.

\section{SOUV. PRESIDENT CARNOT. (Hybrid Tea.)}

Large, full, double, exquisitely shaped flowers, with heary, thick, shell-like petals. The buds are long and pointed like Niphetos-perfection in every line. The color is new delicate rosy blush, shaded a trifle deeper at center of the flower. Fragrance delicious; strong grower and free bloomer; has no weak point. $15 \mathrm{c}$ eacn; two-year-old plants, $35 \mathrm{c}$.

\section{MRS. MAWLEY. (Hybrid Tea.)}

This grand variety embodies so many good qualities that it is difficult to deseribe it. We could say no more in it praise than to say it is like Maman Cochet, only several shadee plghter in color. Price, $15 \mathrm{c}$ each; large two-year-old plants, 36C 


\section{TEN HARDY EVER-
BLOOMING ROSES}

THIS A SPLENDID BEDDING GOLLEGTION

\section{We will send the entire set of ten very fine plants for only 50c. In splendid two-year-old plants, the set of ten for $\$ 1.60$.}

\begin{abstract}
soms, while its color is a degree of loveliness which few deep, rosy pink, a shade the delicate richness of which is seldom seen. Its size is very large for an ever-bloomer, often as large and as fine as often as large and as fine as brid Perpetuals. You will miss a beauty should you fail to get it.
\end{abstract}

New, Hardy, Ever-Blooming Rose, CHAMPION OF THE WORLDThis Rose is the champion bloomer. It is also champion in form and color. Its blossoms are perfectly double to the center and of the most perfect shape both in buds and blos-

WHITE LA FRANCE - (AUgustine Guinnoiseau) Here we have a beauty indeed, recommend to all, whether culture or for pots in the house in Winter. It is identical with La France, except in color: white, some times tinted with fawn.

SCARLET BED. DER - This is without doubt the very best of all red Roses for bedding. It can be planted anywhere, being entirely hardy. Flowers are large size, fiery scar let, a color rarely seen in Roses. Planted everywhere on account of freedom of bloom.

\section{Hardy. Perpet-}

ual- Bl $00 \mathrm{ming}$

Rose, MAD. CHARLES WOOD - A true perpetual bloomer. Begins to bloom almost as soon as planted, and continues all through the season. The flowers are extra large, very double and full, and quite fragrant. Color a bright, fiery scarlet, passing to a fine rosy crimson, elegantly shaded with maroon. Very showy and handsome, and one of the best roses ever introduced for general planting.

BALL OF SNOW (Boule de Neige)-A finely formed, pure white Rose; occasionally shows light flesh when first opening. Beautiful shell-shaped petals, evenly arranged; flowers of good
size.
STRIPED LA FRANCE (Madame Angeline Veysset)-Striped La France combines all the good qualities of a La France in growth, fragrance, shape of bud and flower; in fact, differs not from it except in color. It is nicely striped, the marking being plain and distinct, the variegation a beautiful bright rose on a satin-pink ground. Price, $10 \mathrm{c}$ each; large
two-year-old size, $30 \mathrm{c}$.

STAR OF LYON (Etoile de Lyon) - This magnificent Tea Rose is a rich golden-yellow; a strong, healthy and vigorous grower; immense bloomer, bearing flowers and buds early and late. The flowers are very deep, rich and full, excellent substance, very sweet. Surely one of the very best and most beautiful yellow Tea Roses for general planting ever introduced. Remarkably hardy, both as to heat and cold, frequently standing the Winters here uninjured in open ground without protection and blooming nicely through all the hottest part of the summer.

PINK LA FRANCE-It is of superb form and double as a rose can be. No variety can surpass it in delicate coloring - silvery rose, shaded with pink. It has a satin sheen over all its petals, It is most universally regarded as the most useful of Roses, for it is hardy beyond question. It nously. The flower is large, finely bu i lt, finely b u i t, great length of time, is exquisitely colored, and fragrant in the grant in the
highest degree THE METEOR -A velvetybloomer of the deepest glowing crimson. Avigorous, bushy grower, with healthy, bright foliage of the deepest. green. Unquestionabiy the best dark Relvety - red duced. Grand, both in bud and
flower.

YELLOW MOSELLA-Is another novelty that has been wanted for some years. Who does not know the beautiful Clothilde Soupert, the splendid bedding Rose? Mosella is a stronger grower, flowers are a little larger than the Clothilde Soupert, but appear the same way in clusters and on single stems; the color is a chrome yellow in center, getting creamy white on the edges of the petals. It will make a great bedder and is perfectly hardy.

This Collection must be ordered com- 


\section{Our Ever - Popular \\ Good Luck Collection of Roses}

INCLUDING THE RAREST NEW AND CHOICEST OLD

THIS SPLENDID COLLECTION OF TWENTY CHOICEST EVER-BLOOMING ROSES FOR ONLY \$1.0O

\begin{tabular}{|c|l|l|l|}
\hline \multirow{3}{*}{$\begin{array}{l}\text { This is a magnificent bedding collection of } 20 \text { choice ever blooming } \\
\text { varieties. They are all strong and thrifty, and, above all, exceed. } \\
\text { ingly well rooted. This collection must be ordered complete. It } \\
\text { is sure to please you. }\end{array}$} & 活 \\
\hline
\end{tabular}

MARIE GUILLOT, The Queen of White Roses

For out-door culture. It is first-class in every respect. The color is pure snow-white, sometimes faintly tinged pale yellow. The flowers are magnificently made, extra large, full and double; the buds are very pretty; fragrance very sweet.

\section{STAR OF LYON}

A very free-flowering, deep yellow Rose; handsome buds and flowers; always in bloom.

\section{IETEOR}

A Hybrid Tea of rich velvetycrimson color, with intensely dark shading; a good grower; free bloomer.

\section{MARECHAL NIEL}

Grown the-world over for its magnificent jellow flowers. Especially valuable in the South.

\section{WHITE MARECHAL NIEL}

Identical with its famous parent, save in color, which is a beautiful creamy-white. A grand Rose.

\section{BRIDESMIAID}

(New.) This Rose is fast superseding Catherine Mermet; identical', with it in growth and shape of flower, differing only in its color, which is the most charming pink imaginable.

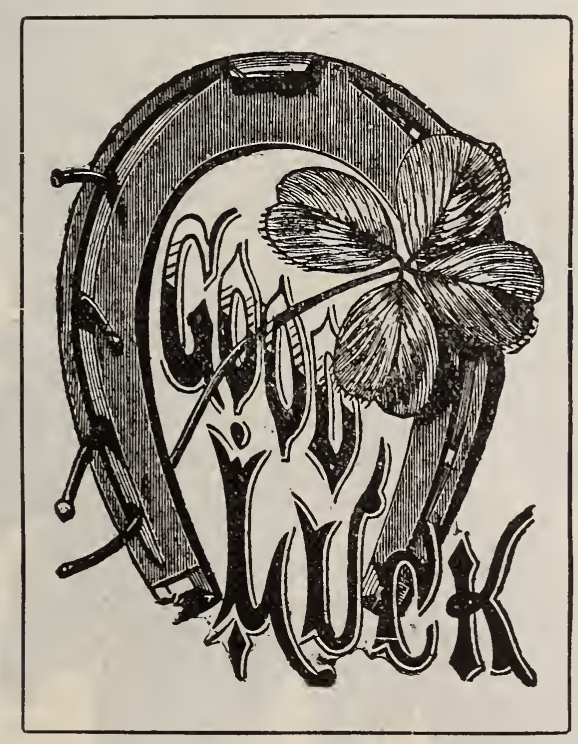

\section{New Hybrid Tea Rose, BALDUIN}

One of the grandest, Roses of recent date. The color is a bright, glowing carmine red. The bud is long and elegantly pointed, and is as sweet as a June Rose. Produced in the greatest profusion all Summer. A most desirable acquisition.

\section{MAD. KRUGER}

Probably the best all-round budding lose we have. Its shadings of deep coppery-yellow stand unique and distinct.

MRS. JOS. LAPERRIERE

Fine china rose color, with silver shadings; bud very long, on a firm stem; flower large, very fragrant and a fine grower.

\section{F. L. SEGERS}

Flowers large and full; color carmine-scarlet, with tints of rose and yellow: odd mingling of colors; fragrant.

\section{SAFRANO}

Grown for its beautiful buds. Color bright a pricot-yellow, changing to orange and fawn, sometimes tinted with rose.

\section{CLOTHILDE- SOUPERT}

The best of all pot Roses; iiter. ally loaded with bloom at every stage of growth. Color beautiful pinkish amber, flushed with silvery rose with shades of salmon.

\section{DUCHESS DE BRABANT}

One of the best new Roses. The extra large flowers are produced on long stems, are very double, and the buds and half expanded flowers are simply exquisite in their graceful form, delicate color and rich fragrance. The color is a lovely rose-pink.

\section{MARIE VAN HOUTTE}

Sometimes called "The Gem." Pale yellow, the edges of the petals often lined with rose; well formed, fragrant and of good habit. Very free blooming, and in every respect a most charming sort. One of the hardiest and finest for out-door culture. Should be in every collection.

\section{SCARLET BEDDER}

Intense deep, rich, velvety-scarlet, and a profuse bloomer. You make no mistake in purchasing this Rose.

\section{New Tea Rose, SNOW FLAKE}

It is a lovely white Tea-the freest flowering Rose we have ever seen.

This Rose combines exquisite perfume, beatiful coloring, and a matchless profusion of flowers and foliage. How shall we describe its coloring? Soft, light rose, with heavy shading of amber and salmon. Quite hardy, and in every respect it is admirable.

\section{MADA ME SCHWALLER}

A Hybrid Tea having the fragrance of La France and the firmess of the Hybrids, with the freedom of flowers of the Tea class. Rosy-carmine, sometimes deep rose. A most abundant bloomer.

\section{THE BRIDE}

It is a pure white Rose of large size and most perfect form. This variety has the most delicious Tea fragrance; and is a strong-growing, free-blooming Rose.

\section{MOSELLA}

The petals are tinted white, on beautiful light-yellow ground extending to the middle of the petals. The plant is dwarf, bushy and free blooming. A beautiful new Rose. 


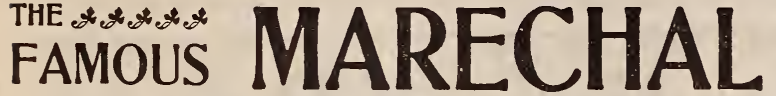 NIEL ROSES RED, WHITE AND YELLOW VARIETIES.}

I ARGE SIZED MARECHAL NIELS. - We grow the largest, best and strongest=rooted Larechal Niels in this or any other city. If you want the very best, try ours. They are large and nicely shaped, and, above all, they are exceedingly well rooted.

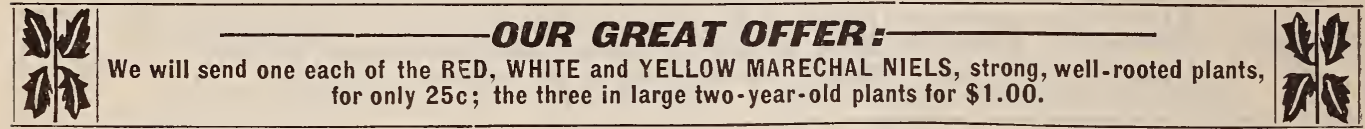

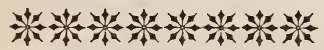

THE WHITE

MARECHAL NIEL...

Identical with its famous parent, save in color. The fame of Marechal Niel, with its large, deep, golden-yellow flowers is so world-wide that nothing further need be said of this new variety to make it instantly popular than that it is the exact counterpart in every respect of Marechal Niel, its parent, save the color of flower, which is a pale, creamy-white. Totally distinct. This remarkable variety is selling at enormous prices in Europe, where it originated. We consider ourselves for tunate in possessing some of the original stock plants, procured direct from the introducer, from which our stock has been propagated. It is a rapid climber, and quickly makes a bush of considerable proportions. For Southern cultivation it will be of great value, and as a companion plant to a splendid dəmand for it.

\section{PRICE:}

Strong plants, $10 \mathrm{c}$ each; large, two-year-old plants, $30 \mathrm{c}$.

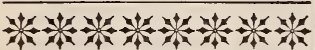

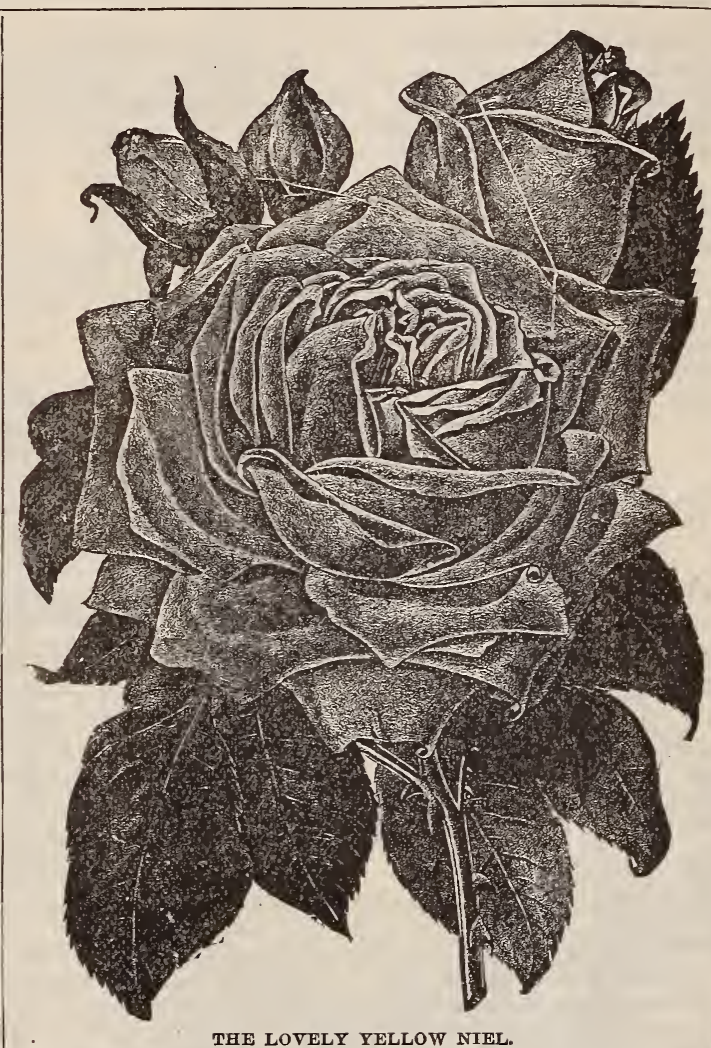

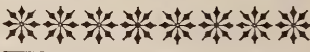
THE YELLOW MARECHAL NIEL...

The World Renowned Rose.

A beautiful, deep, sulphur-yellow, very large and exceedingly fragrant. It is the finest yellow Rose in existence. It has a climbing habit and where it is allowed to grow until it attains a large size, as it will in a few years, it yields thousands of b e a u tif u l, golden-yellow flowers. E.pecially desirable for the South We have a grand stock of this variety. PRICE:

First size, 10c each; large and nicely shaped two-year-old bushes at $50 \mathrm{c}$, and an extra strong, robust fellow, that will take care of himself anywherethe best you ever got- $\$ 1.00$.

\section{THE RED}

MARECHAL NIEL...

This grand new Rose is a strong, $\nabla$ ig or o us grower flowers large, full and of fine form; color a pure cherryred and sweet-scented. A splendid Rose, and destined to become very popular. Offered for the first time last Spring.

PRICE :

$15 \mathrm{c}$ each; large two-year-old plants, 50c.

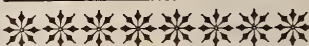

NOTE-WE WOULD STRONGLY ADVISE ORDERING THE LARGE NIELS BY EXPRESS. SUCCESS IS THEN CERTAIN 00000000000000000000000000000000000000000000000000000000000000000000000000000000 MID-WINTER COLLECTION OF EVER-BLOOMING ROSES

IF ALI CHOICE KINDS. We have made a selection of the very best Roses for Winter blooming, embracing a wide range of color. We can commend this collection to all who desire to grow Roses in the house during Winter PRICE FOR THE COLLECTION OF SIX CHOICE “MID.WINTER" BLOOMING ROSES ONLY 400.

DUCHESS DE BRABANT-Sometimes called "Countess de la Barthe." Rosy-salmon, shaded amber, beautifully cupped and very fragrant; a wonderfully free bloomer; one of the best bedding Roses. Should be in the smallest collection.

ISABELLA SPRUNT-Flowers freely during the Winter. Flowers of the richest yellow color.

PAPA GONTIER-Deep red. Very free and rery sweet.
THE BRIDE-The best Winter-blooming white Rose. Planted by the million by growers of cut flowers.

BRIDESMAID-This is a fit companion for the Bride. $\cdot$ It is also planted by the million for Winter-blooming. The best deep pink Rose for the purpose.

SAFRANO-The old standby for a Winter-bloomer. Lovely saffron-colored buds of the most delicious fragrance.

4FPET: This entire collection of six "Mid-Winter" blooming Roses for only " 400.

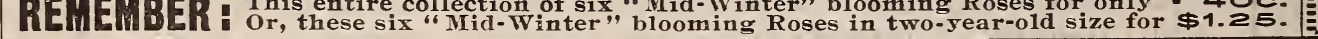




\section{EVER BLOOMING}
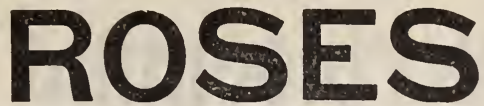

CLIMBING VARIETIES

Prices on these grand climbers a re greatly reduced this Spring. In the South and Middle States, where they stand the Winter, nothing cau compare with them for beauty and foliage. They are never to be forgotten when seen in full bloom loaded with thousands of magnificent flowers. Large two-year-old plants of Climbing Tea Roses, 25 cents each, except were noted.

\section{The Wonderful New Rose, \\ CIImbing Kaiserin, or} MRS. ROBERT PEARY

This is by all odds the most remarkable new Rose of recent introduction. It is an off spring of that grand variety, Kaiserin Augusta Victoria. The flowers are extra large, full, deep and double. They are of excellent substance, and produced on long, stiff steins, like a forcing Rose. The buds are long and pointed, a remarkable feature not found in any other Climbing Rose. The color and shape of the bud and flower are identical with Kaiserin Augusta Victoria. Pure ivorywhite. The foliage is also identical. The fragrance is delicious. The most remarkable feature of this variety, however, is that it blooms continuously the first vear. It grows to perfection out doors, throwing up numerous shoots ten to to perfection out doors, throwing up numerous shoots ten to plants, $35 \mathrm{c}$ each.

\section{REINE MARIE HENRIETTA}

This is the best climbing Rose in this set, and no collection would becomplete in New Orleans or the South that did not comprise this, the grandest of all ever-blooming Roses. Ex. tra large, finely formed flowers, very full and double, borne in clusters; color glowing crimson. Price, 10c each; iarge plants, 30 s each.

\section{President Cleveland, or}

\section{GLIMBING MARIE GUILLOT}

This grand new Rose is known in different parts of the country under both the above names. Of a semi-climbing habit and is identical with Marie Guillot, the loveliest of all white Roses, except it is a climber. It is worthy a place in any flower garden. Price, $10 \mathrm{c}$ each; two-year-old plants, $30 \mathrm{c}$ each.

\section{The Superb Scarlet Rose,}

\section{"CLIMBING WOOTON"}

This elegant new Climbing Hybrid Tea Rose is one which promises to be a prime favorite wherever introduced. Every. thing good that can be said of the grand Rose, Souventr de Wooton, can be said of this Rose, and more too. The fiowers are large and of a reivety-red color, and the perfume is elefine shape. The flowers are borne at the terminus of long shoots, which renders them especially good for cutting, much better, in fact, than the flowers of its parent, Souvenir de Wooton. Price, 10c each; large size, 30c ea $-h$.

\section{WILIAM ALLEN RIGHARDSON}

Orange vellow, with outer petals lighter, center a coppery sellow, very rich rapidly becoming popular. All Rose growers, where the climbing Teas are hardy, should plant this beautiful Rose, as it is a unique and lovely shade of yellow. Something entirely distinct in Climbing Roses. Price, $10 \mathrm{c}$ each; two-year old plants 25 cents.
Worid-Renowned Rose,

\section{YELLO W MAREOHAL NIEL}

A beautiful deep sulphur-yellow, very full, very large and ingly fragrant. It is the finest yellow Rose in existence. It has a climbing habit, and where it is allowed to grow until it attains a large size, as it will in a few years, it vields thousands of beautiful golden-yellow flowers. Especially dePrice, first size, 10c each; large and nicely shaped two-year-old plants, $50 \mathrm{c}$ each.

\section{GLIMBING BELLE SIBREGHT}

Identic al with Belle Sibrecht, except that it is a vigorous climber. Its delicate, bright pink flowers measure five to six plants, $35 \mathrm{c}$ each.

New Ever-blooming Rose,

\section{OLIMEING MALMAISON}

A sport from the well-known Souv de la Malmaison, similar in flower and foliage to its parent, but of exceedingly robust climbing habit. There is no finer Rose than the old, wellknown Malmaison, or "Souvenir" of the South, and we are sure that our patrons. one and all, will be glad to hear that we have a climbing variety that is identical with the parent. First time offered. The variety will prove of inestimable value to all lovers of fine climbing Roses. It will prove per-
fectly hardy south of Washington. D. C. Price, 10c each; large two-year-old plants, $25 \mathrm{c}$ each.

\section{GLOTH OF GOLD, OR GHROMATELIA}

A clear, golden-yellow bronze; rery full and double; verandas. Price, 10 each, two-year-old plants, $25 \mathrm{c}$ each.

\section{SOLFATERRE}

Fine, clear sulphur yellow; large, full and double; very sweet. Price, $10 \mathrm{c}$ each; two-year-old plants, $25 \mathrm{c}$ each.

\section{LAMARQUE}

Large, full flowers; borne in large clusters; pure white and double; a most beautiful Rose. A rampant climber Price, $10 \mathrm{c}$ each; two-year-old plants, $25 \mathrm{c}$ each.

\section{CEIMBING DEVONIENSIS}

White, flushed pinle; pure Magnolia fragrance. Price, $10 \mathrm{c}$ each; two-year-old plants, $25 \mathrm{c}$ each.

\section{WHITE MAREGHAL NIEL}

Identical with the vellow Niel, except color of flowers, which are pure white. See page 9 for description. Price, $10 \mathrm{c}$ each; large two-year-old plants, $35 \mathrm{c}$ each.

Any three for 25 cents. Price per single plant, 10 cents. In large two-year-old plants we will send you the full collection for $\$ 2.00$ WE HAVE frequent inquiries as to the best varieties of everblooming Ruses for cemetery planting, and we here give a select list that is just adapted for this purpose. In northern latitudes they ought to have a covering of forest leaves in Winter. In ordering, simply say " -ver-biooming Cemetery Collection."

\section{CLOTHILDE SOUPERT}

One of the most prolific bloomers in our entire list an admirably adapted for out-door bedding. Beginning to flower when not over four inches high and continues without intermission the entire season. Price, 10c each.

\section{MARIE GUILLOT}

Perfection in form, flowers large and double to the center. This holds first rank among white double Tea Roses in purity of color and depth of petals. Best white Tea Roses for outdoor bedding. Psice, $10 \mathrm{c}$ each.

\section{MARIE LAMBERT}

A strong rigorous grower with small pure white flowers; has been called White Hermosa, as it resembles Hermosa in form and freedom of bloom; a valuable bedding variety. Blooms all Summer long. Price, $10 \mathrm{c}$ each.

\section{MOSELLA}

The petals are tinted white, on beautiful light jellow ground extending to the middle of the petals. The plant is dwarf, bushy and free blooming. A beautiful new white Rose. Price, 1 c each.

\section{MARIE VAN HOUTTE}

A beautiful and prolific Rose; white, lemon-yellow. It is also a fine grower. Price, $10 \mathrm{c}$ each.

\section{BALL OF SNOW}

In the "Ball of Snow" we have a Rose of large size, which is perfectly double, exquisitely fragrant, pure white color and entirely hardy. It is invaluable for cemetery or other planting where white flowers are desired. Price, 10c each; large plants, $25 \mathrm{c}$ each.

\section{THE BRIDE}

It is a pure white Rose of large size and most perfect form. This variety has the most delicious tea fragrance, and a strong growing, free-blooming Rose. Price, $10 \mathrm{c}$ each.

\section{SNO W FLAKE}

A charming sort; there is no better white Rose; its persistence in bloom makes it very popular for cemetery plant ing. Price, 10c each.

\section{THE QUEEN}

It is pure snow-white, makes good finely formed buds, is quite full, showing the center but slightly when fully open. The petals are thick and of good substance. Price, $10 \mathrm{c}$ each.

MADAME JOSEPH SGHWARTZ

White, beautifully flushed with delicate pink; a delight ful Rose that is sure to please. Price, 10c each. 


\section{Choicest Euerblooming Cea Roses At Only Six Cents Each When TEN OR MORE are ORDERED at ONE TIME.}

\section{A SPENDID OPPORTUNITY TO GET THE CHOICEST ROSES OF YOUR OWN SELECTION AT LESS} THAN HALF PRICE. MANY OF THEM ARE NEW AND RARE. where priced otherwise. Large Two-Year-Old Plants, Twenty Cents Each, except where priced otherwise.

Star of Gold.

One of the finest of yellow Roses, and also one of the best out-door bedders. As large as Marechal Niel and of deep chrome-yellow color. Price, 10c each; large size, 25 c.

The Queen.

It is pure snow-white, makes good, finely formed buds, is quite full, showing the center but slightly when fully open. The petals are thick and of good substance, opens well, is very sweet, and has proved valuable both for forcing and open ground planting. A valuable aequisition to our list of pure white, everblooming Roses. Price. $10 \mathrm{c}$ each: large, two - year - old plants, $25 \mathrm{c}$.

Pierre Migron.

A very delicate shade of light pink. This is a very beautiful new Rose, and will become a great large two-year-old plants, $25 \mathrm{c}$.

\section{Bon Silene.}

Still a prime favorite on account of its delightful fragrance and strong growing qualities: color, deep rose, shaded carmine. Valuable for Summer or Winter flowers. Price, 10c each; large size, $25 \mathrm{c}$.

\section{Maid of Honor.}

It is a sport from Bridesmaid, and is several shades deeper than that variety. Its connection with the Mermet family of Roses would indicate its worth. Flowers borne on long stems in form somewhat larger and exceeding in size and number of its petals. Color carmine-pink (when we say carmine we mean all that the word implies), shaded brilliantly on the outside petals, color increasing in intensity toward the end of the petal, and approaching the center of the bud each petal increases in intensity of color. Price, $8 \mathrm{c}$ each; large two-year-old plants, 25c.

\section{Mad. Joseph Schwartz.}

A lovely Tea Rose; extra large, globular flowers, very full and sweet; color pure white, tinged and shaded with pale yellow and rosy-blush; very beautiful Rose; constant and profuse bloomer. Price, $10 \mathrm{c}$ each; two-year-old plants, 25c.

\section{Antoine Weber.}

Very perfect in bud; flower large and very full; color, "hydrangea pink," A very free grower, and recommended as a fine hedder. Price, $10 \mathrm{c}$ each; two-year-old plants. 30c.
Muriel Graham.

The latest addition to the Mermet family, being a sport from that fine variety identical with it in every. thing save color, which is creamy-white, $s$ u ff u s e d with delicate pink. A color intermedia te between Mermet and Bride, a n d as dainty as possible to imag ine. Price, $10 \mathrm{c}$ each; twoyear-old plants, $25 \mathrm{c}$.

\section{Climbing Meteor.}

This Rose has gained a world - wide reputation as the finest crimson everblooming climbing Rose in cultivation. It is rich, velvety-crimson, much like the forcing Rose Meteor, of which it is a sport. An extremely strong growing variety, making shoots 12 to 15 feet long in a single season under favorable circum stances. South of the Ohio river it would be perfectly hardy, while in the extreme north it could be laid on the ground and covered with leaves or straw and will carry through nicely. Price 10c each; two-year-old plants. $30 \mathrm{c}$.

Madame Husson.

A light colored Rose with yellow center, like Madame Caroline Kuster, only deeper and richer. Price, 10c each; two-year-old plants. 25c.
Mad. Lambard-A Good Bedding Rose.

A first-class Rose for bedding; extra large, full flowers, very double and sweet; color a beautiful shade of rosy-bronze passing to salmon and fawn, beautifully shaded with carmine. An elegant Rose, of vigorous habit of growth; very free and constant bloomer. Price, $8 \mathrm{c}$ each; large size, $20 \mathrm{c}$.

\section{Comtesse Lily Kinsky.}

A strong, vigorous grower, bearing large, full flowers of fine, regular form; color white, delicately tinged with blush; chamois yellow center; very sweet and pretty. Price, $8 \mathrm{c} \mathrm{each;}$ large size, 20c.

\section{The Bridesmaid.}

Grand new sort from Mermet. Color, rich, deep pink. Bestand largest pink Tea Rose. Price, $10 \mathrm{c}$ each; large size, $20 \mathrm{c}$

\section{Madame Camille.}

Delicate rosy-flesh, changing to salmon-rose. Price, $\mathbf{8 c}$ each; large size, $20 \mathrm{c}$.

The Superb Yellow Rose, Marechal Niel. The Most Popular of All.

A Rose so famous as to really require no description. Its magnificent golden-yellow buds are worn the world over. Price, 10c each. Splendid, large two-year-old plants, 50c. 


\section{Lucie Faure.}

Flower large and full, of good substance and ivory-white. The budsare long, and held on good stems; large outer petals diminishing in size to the center. Price, $10 \mathrm{c}$ each; large twoyear-old plants, $25 \mathrm{c}$.

\section{Golden Gate.}

A magnificent Rose with large, full, finely-formed flowers; buds long and beautiful. Color rich, creany-white tinged with golden yellow and clear rose. A free blooming beautiful variety. Price, 10c each; large size, 25c.

\section{Safrano.}

An old favorite. Bright apricot-yeilow, changing to orange and fawn, frequently tinted with rose. Desirable for out-door planting and much prized for it $s$ fragrance and nicely sha ped bloom. Price, 8c each; large size, $20 c$.

\section{Queen's}

Scarlet.

In this variety we have a hardy, ever-blooming crimson-scarlet Rose, a combination of qualities that make a valuable Rose for garden culture; a bed once established is a mass of bright scarlet bl $00 \mathrm{~m}$ the entire blooming sea. son. Price, $8 \mathrm{c}$ each; large size, $20 \mathrm{c}$.

Marie Guillot.

White, tinged with a delicate shade of lemon; large, full and beautifully imbricated in form; one of the finest white Teas. the perfection of form in Tea Roses:

highly fragrant. Price, $8 \mathrm{c}$ each: large size, $20 c$.

Marie Van Houtte.

Creamy-white, with the outer petals washed and outlined with a bright rose; occasionally the whole flower is suffused with light pink. This beautiful variety suceeeds everywhere. It grows vigoronsly, blooms freely, and is most deliciously scented. Price, $8 \mathrm{c}$ each; large size, 20c.

Mad. Martha DuBourg.

Habit and foliage beautiful; the flower is large, perfectly double and of rounded form : the outer petals recurve at the edges, showing a nicely pointed center: the color is creamy - white, touched with carmine or pale heliotrope on the edges; texture heavy. Price, $8 c$ each; large size, $20 \mathrm{c}$

\section{Madame Welche.}

Flowers of great depth: fine globular form, with broad, thick petals; color a beautiful shade of a mber-yellow, deepening toward center to orange or coppery-yellow, delicately clouded with pale crimson. Fine for open ground. Price, $10 \mathrm{c}$ each; large two-year-old plants, $25 \mathrm{c}$.

\section{New Climbing Rose, Carmine Pillar.}

This is a lovely new Rose, producing flowers from three and one-half to four inches across, semi-double, of the brightest possible scarlety-carmine, as rich as Douglas and produced very abundantly, the display lasting through most of the season, perfectly hardy, one of the very finest ornamental climbing Roses of the freest growth. Price, $8 \mathrm{c}$ each; large, two-yearold plaits, 25 c

\section{F. L. Segers.}

Flower large and full: color carmine-scarlet, with tints of ro $*$ and yellow; odd mingling of colors; fragrant. Price, $10 \mathrm{c}$ each; large two-year-old plants, $25 \mathrm{c}$.
Sylph.

Ivory - white, tinted peach; large, high centered, with I free in bloom. A fine, new Rose. Price, $15 \mathrm{c}$ each; two-year-old plants, $30 \mathrm{c}$ each.

\section{Antoine Rivore.}

Flowers large and of Camellia-like form ; clear, rosy-flesh, shading to yellow, shaded and lined bright carmine. A superb variety and very free. Price, $10 \mathrm{c}$ each; two-year-old plants, $30 \mathrm{c}$.

New Yellow Soupert, Mosella.

It blooms in profuse clusters of three to five flowers which are very double, ball shaped, and open like Camellia flower. The petals a r e tinted white, on beautiful light yellow ground extending to the middle of the petals. Price, 8c each; large size, $20 \mathrm{c}$.

Devoniensis.

Creamy - white, center yellow. Large, fine and very fragrant. Some times called "Magnolia Rose" on ac count of its delightful fragrance. Price, 8c each; large size, $20 \mathrm{c}$.

Queen Olga of Greece.

A very strong grower, with large flowers of magnificent satin-rose color and is extremely beautiful. When fully open, four and a half inches across. Price, 10c each; large two - year - old plants. 35c.

\section{Meteor.}

We have no red Rose that is better for general purposes many perfect shaped flowers on nice, long stems. The color is rich, velvety-crimson, exceedingly bright and attractive. The plant is of vigorous growth and very free flowering; a constant bloomer. Fine for Summer bedding or pot culture Price, 10c each; large size, 25c.

\section{Mad, Schwaller.}

A remarkable Rose, having the strength and style of the Hybrid Perpetual and the free flowering qualities of the Tea. Color, deep, rosy-flesh; deepening on edge of petals. Price, 8c each; large size, 20c.

\section{Mad. Etienne.}

A delicate pink, shaded deeper at edge of petals. Flowers large and ver. double; produced freely. Price, 10c each; large size, 25c.

The Bright Rose, Isabella Sprunt.

A bright canary-yellow, large, beautiful buds, suitable for cut flowers: a very sweet tea scent profuse bloomer. It is no doubt the freest bloomer of al yellow Roses. This variety has been a favorite in all gardens where good yellow Roses are planted for the past twenty where good yellow Roses are planted for the past twenty
years. There are none better. Price, 10c each; large size, 20c.

Souvenir de Catherine Guillot.

Coppery-rose. Very fine. Price, $8 \mathrm{c}$ each; large size, $20 \mathrm{c}$.

\section{Rainbow.}

Color a lovely shade of deep coral-pink, striped and mottled in the most unique manner with intense crimson, and elegantly colored with rich golden-amber at center and base of petals. Flowers extra large. Price, $8 \mathrm{c}$ each; large, two-yearold plants, $25 \mathrm{c}$.

\section{Marquis De Vivens.}

The color is a novel shade of rich violet, with center and The of petals ereamr-yellow, exquisitely tinted salmon and fawn. large, full flowers; sweet. Constant and profuse bloomer. Price, 8c each; large size, 20c. 


\section{CHOICE ROSES AT SIX CENTS EACH}

\section{Papa Gontier.}

An excellent crimson Tea, and one of the best for all purposes. It has a perfect shaped bud on good length of stem, making it desirable for cut flowers, and when planted outside the flowers open up nicely and are of an attractive carmine erimson: should be included in every collection of Roses. Price, 8c each; large size, $25 \mathrm{c}$.

\section{Maman Cochet.}

One of the best new Roses. The growth is vigorous, with rich, healthy foliage. The extra large flowers are produced on long stems, are very double, and the buds and half-expanded flowers are simply exquisite in their graceful form, delicate color and rich fragrance. The color is deep rose-pink, the inner side of the petals silvery-grey. Price, 10c each; large two-year-old plants, $25 \mathrm{c}$

A Lovely New Rose, Lady H. Grosvenor.

(Hybrid Tea.) Flowers beautiful flesh color, large, full and (lobular An exceedingly free flowering Rose, and a splendid sort for forcing. Price, $8 \mathrm{c}$ each; large size, 20c.

\section{Snowflake.}

A strong, vigorous grower with small, pure white flowers Has been called White Hermosa, as it resembles Hermosa in form and freedom of bloom. A valuable bedding variety. Price, $8 \mathrm{c}$ each; large size, $20 \mathrm{c}$.

\section{Wonderful New Climbing Rose, Empress of China.}

This is a new Climbing Rose of the greatest excellence. It commences to bloom in May, and is loaded with its elegant blooms until December. There is no other Rose like it that will bloom for so long a time. It is simply wonderful. When it first opens the flowers are a beautiful red, but soon turn to a lovely light pink, and it blooms so profusely as to almost hide the plant. It is perfectly hardy and is a vigorous grower. Price, $8 \mathrm{c}$ each; large size, 25c.

\section{Mad. Franciska Kruger.}

Probably the best all round bedding Rose we have Its shadings of deep, coppery-yellow stand distinct and unique. Price. $8 \mathrm{c}$ each; large size, 20c.

\section{Enchantress.}

Creamy-white, tinted bufi at the center; large, full and globular; of vigorous growth and extremely free in bloom very distinct and effective; recommended by the raiser for pot culture and for Winter bloom. Price, 10c each; large, twoyear-old size, $25 \mathrm{c}$.

\section{Medea.}

Flowers bright lemon-yellow, with canary-yellow centers. $\nabla$ ro full buds, with high centers; foliage dark and thick in Very full buds, with high centers; foliage dark and thick in
color like Perle. This variety produces most of its buds of im color like Perle. This variety produces most of its buds of imof what a Tea Rose should be. Price, 8c each; two-year-oid plants, $25 \mathrm{c}$

\section{The Mary Washington Rose.}

This famous old Rose was newly introduced to the public recently. Its flowers are pure white, perfectly double to the center, sweet, and borne in endless numbers all summer. It is a vigorous and rapid grower. It makes a great profusion is a vigorous and rapid grower. It makes a great profusion of fine buds, which are borne on long stems and usually in large clusters. Its fragrance is tinged with that old fashioned large size, 25c.

\section{Beaute Inconstant.}

(The Rose of many colors.) A single plant will bear flowers ranging in color from coppery-yellow, blush-pink, carmin and apricot to light crimson. The bud is especially fine, being a coppery orange-scarlet, all the variations of color are to be found in the open flower. Price, 10c each; large size, 25c.

\section{Princess Venosa.}

A strong grower, producing a long bud; flower large, moderately large and beautifully formed; color nankeen-yellow, with shadings of carmine; a most remarkable combination of colors. Price, $8 \mathrm{c}$ each; large size, $25 \mathrm{c}$.

\section{Mrs. DeGraw.}

Hybrid Tea. A strong, vigorous grower; a rich, glossy pink color, delightfully fragrant, and produces flowers in pibundance from early Spring until frost. Priee, 8c each; large size, $20 \mathrm{c}$.

\section{Mme, Pierre Guillot.}

Tea. One of the most beautiful Mermet-like buds; cream color, shading to a yellow base; edges of all petals bright rose color: the form of bud extra fine, and flowers are freely procolor; the form of bud extrice, $10 \mathrm{c}$ each; large size; $20 \mathrm{c}$.

\section{Agrippina.}

Rich, beautiful crimson; beautiful in bud. For bedding it is unsurpassed. Few Roses are so rich in color. Price, $8 \mathrm{c}$ each; iarge size, 20c each.

The Bride.

A lovely pure white Rose of the Mermet type. It is very full and double, free flowering and excellent either for forcing or for Summer planting. Price, 10c each; large size, 20c.

\section{General De Tartas.}

A first-class Rose for bedding. Brilliant carmine, deeply shaded with violet-purple; extra large; very double, full and fragrant. Price, $8 \mathrm{c}$ each; large size, 20c.

\section{Clothilde Soupert.}

The best of all pot Roses; literally loaded with bloom at every stage of growth. Color, beautiful pinkish amber, flushed with silvery-rose with shades of salmon. Price, 8c each; large size, 20c.

\section{J. B. Varonne.}

There is no question about this being a truly splendid Rose. It has the form, color and substance of those very choice and valuable varieties which only come occasionally. Superb, elongated buds and extra large vase-shaped blooms: color intense scarlety - crimson, very rich and bright, and beautifully shaded salmon-yellow or buff-rose at center; exceedingly beautiful, very sweet and a constant bloomer. Price, 10c each; large size, 25c.

\section{Madame De Watteville.}

The color is a remarkable shade of creamy-yellow, richly colored with rosy.blush. The petals are large and each on widely bordered with bright crimson, which gives it a very striking and beautiful appearanse. The flowers are large, very full and highly perfumed. For planting in the open ground Madamo de Watteville takes front rank, being a hard vigorous grower, a profuse bloomer and unsurpassed for cut ting. Price, $10 \mathrm{c}$ each; large size; $20 \mathrm{c}$.

\section{Louis Richard.}

A superb Rose imported from France; extra large size; splendid, full form, very double ; delicious Tea scent; color; rich, coppery-rose, changing to buff, shaded with carmine; center sometimes brilliant rosy crimson. Price, $8 \mathrm{c}$ each; large size, $20 \mathrm{c}$.

\section{Christine De Noue.}

The new Tea Rose and one that is particularly valuable, because red has always been a scarce color among Tea Roses, and this one seems exceptionally fine. Price, $8 \mathrm{c}$ each; large size, 20c.

\section{The Beautiful New Pink Soupert.}

This bright new Rose is a very free flowering variety, much resembling Hermosa but more double and flowering more freely. It shows the Polyantha blood in the full cluster of bloom and it will make a handsome contrast, bedded or grown wlth the C. Soupert. The flowers are not quite so large, full and handsome as our original Soupert, but fill a place because of their brightness and freedom. The habit of the plant is almost identical with C. Soupert. Price, $\mathbf{8 c}$ each; large size, 20c.

\section{Mad. Caroline Custer.}

Bright lemon-Fellow; very large and handsomely shaped: one of the finest Roses; very free flowering. Price, $8 \mathrm{c}$ each; large size, 20c.

\section{James Sprunt.}

A grand Rose. Deep cherry-red; medium size, full, double and sweet. A strong grower and profuse bloomer. Price, 8c each; large size, 20c.

\section{Catherine Mermet.}

One of the finest Roses grown. Its name is the synonym for all that is delicate and beautiful. Its buds are inimitable, faultless in form and charming in every shade of color, from the purest silvery-rose to the exquisite combining of yellow and rose, which illumines the base of the petals. I $i$ is, beyond doubt, the Rose of all the Roses, and you should not fail to have a Mermet in your collection. Price, $8 c$ each; large size, 20c.

\section{Joseph Metrel.}

Extra large flowers, very full, handsome and sweet; deep carnation-red, passing to cherry-carmine or magenta. A good, healthy grower and abundant bloomer. Price, $8 \mathrm{c}$ each; two-year-old plants $20 \mathrm{c}$.

\section{Jules Finger.}

A magnificent Rose; elegant and valuable; the color is bright rosy-scarlet, beautifully shaded with intense crimson. Price, 8c ; large size, 20c. 


\section{BLACK AND WHITE HARDY ROSES}

The wonderful contrast between these beautiful Roses must be seen to be appreciated. Order a set of each and see how lovely they are.

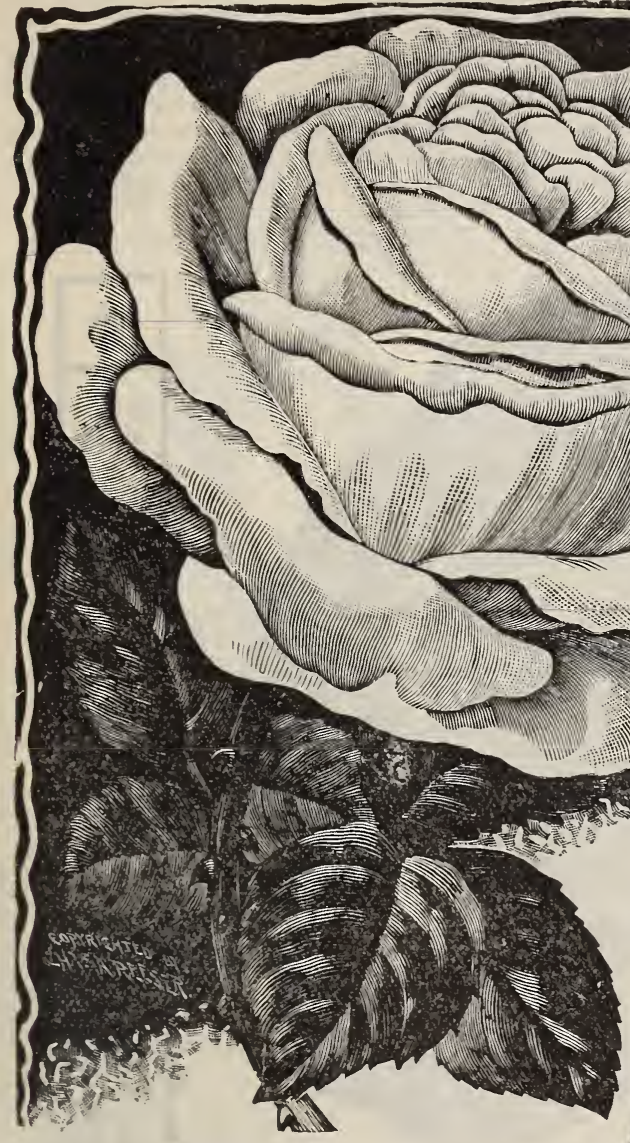

\section{Three Beautiful Pure White Hardy Roses.}

\section{These are nice sorts to plant in the cemetery, as they are perfectly hardy. The set for only $25 \mathrm{c}$. Large two-year-old size, the set, 75 cents.}

Mad. Alfred de Rougemont

A strong, vigorous grower; begins to bloom at once and continues until stopped by severe freezing. Pure snow-white flowers, finely tinged and clouded with pale rosy, blush, large, full and double and borne in large clusters; fragrant and good. Price, $10 \mathrm{c}$ each; large two. year-old size, $30 \mathrm{c}$ each.

\section{Coguette des Blanches}

One of the finest white Hybrid Perpetuals. Its flowers are largepure snow white, very double, full and fragrant. A constant bloomer. One of the best. Price, 10c each; large two year-old size, $30 \mathrm{c}$ each.

\section{Madame Plantier}

The iron-clad white cemetery Rose. It bears thousands of beautiful snowy-white, fragrant Roses. It is as hardy as an oak. Price, $10 \mathrm{c}$ each; large two-year-old plants, 30c.

PLRE THITE ROSE, COQCETTE DES BLANCHES.

\section{Three Lovely Black Roses}

These are exceedingly beautiful-the darkest of all Roses. Set of three for only 25 cents. The three in large two-year-old size, only 75 cents.

\section{PrInce Camllle de Rohan}

A rery dark, rich, velvety crimson, passing to intense maroon, shaded black. Large, full flowers, looking at a little distance as if they were really black. One of the darkest Roses and very handsome. Price, $10 \mathrm{c}$ each; large size, $30 \mathrm{c}$ each.

\section{Souv. de Duchere}

A superb Rose; extra large, compact flowers; very full, double and sweet. Color a beautiful and brilliant scarlet, deepening to dark, glowing crimson. Very rich and handsome. Price, $10 \mathrm{c}$ each; large size, $30 \mathrm{c}$ each.

\section{New Rose, Black Prince}

A superb Hybrid Perpetual Rose, dark black red, richly shaded with violet-crimson; extra large. Price, 10c each; large size, $30 \mathrm{c}$ each.

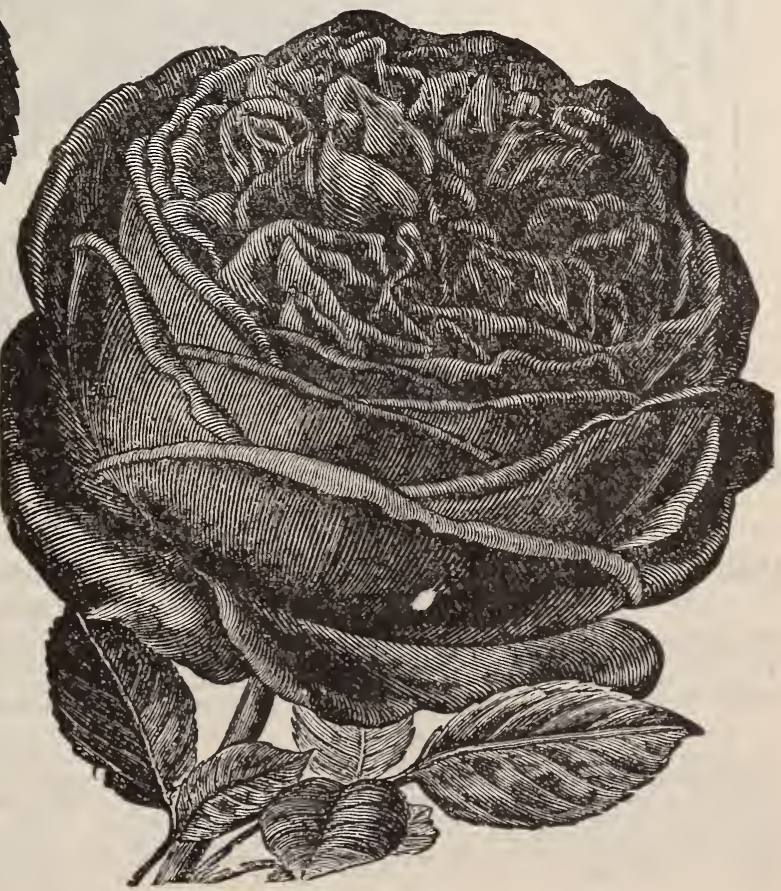

THE MAGNIFICENT ROSE, BLACK PRINCE. 


\section{Gardy Fybrid Perpetual Roses = F FPECIAL MERIT}

H YBRID PERPETUALS are considered the most valuable of all hardy plants. They are distinguished by their vigorous upright growth and large, bold flowers, frequently measuring five to six inches in diameter. They thrive and succeed in all localities and are entirely hardy in any part of thecountry, and will live through severe Winters with a light protection of leaves or coarse manure. Some varieties do not bloom until the second year, but when fully established they all bloom freely at the usual time, early in the season, and continue to bloom during the Summer and Autumn months. Hybrid Perpetuals will bear a considerable amount of hardship and neglect, but improve greatly with good cultivation and rich soil. They should invariably be planted in open ground, as they are not suitable for house culture.

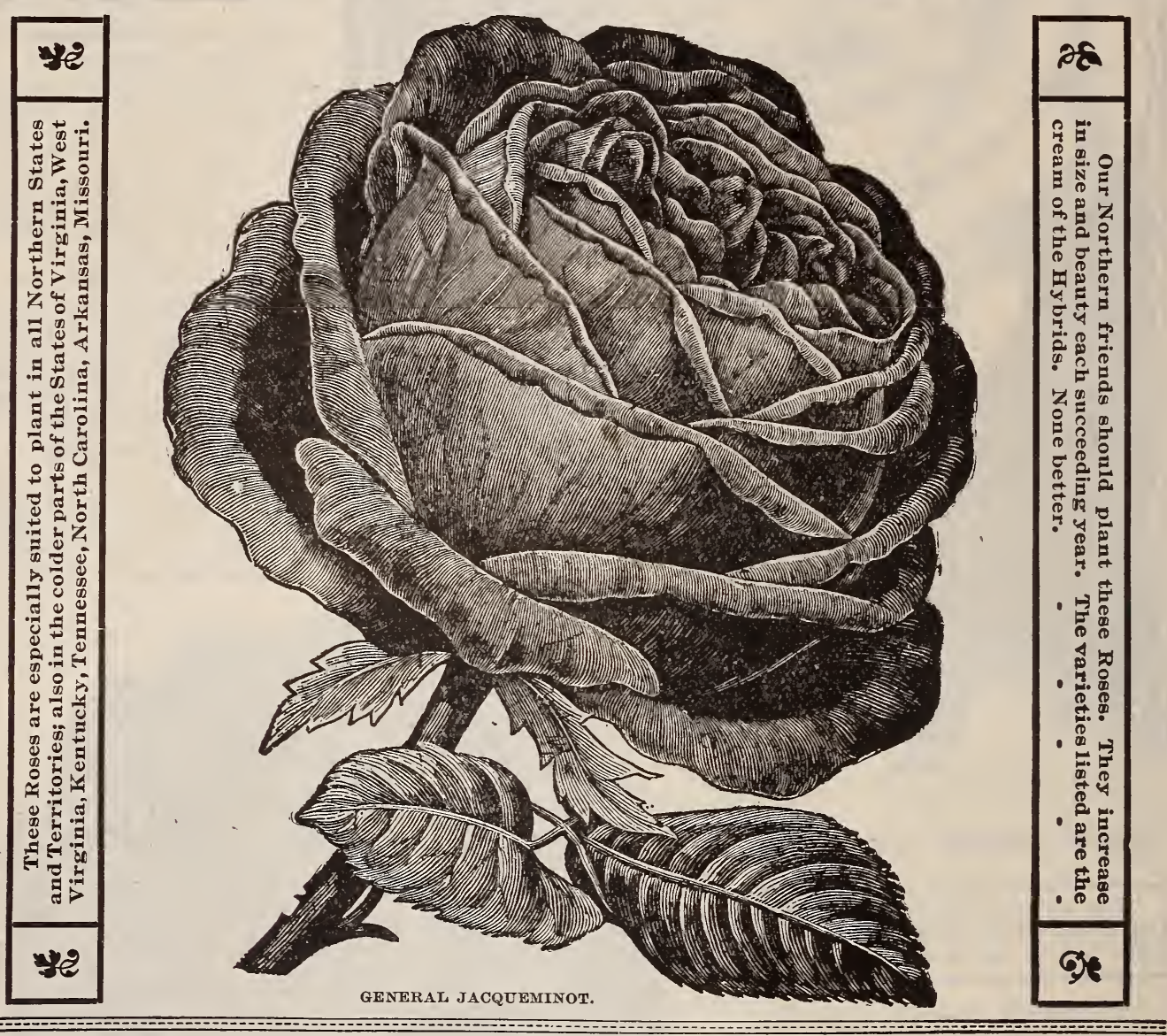

\section{A MAGNIFICENT OFFER.}

\section{Our Iron-Clad Collection of Eight Splendid Large Two-Year-O1d Hardy Hybrid Perpetual Roses for $\$ 1.00$.}

THESE are the Roses that agents and nurserymen charge 50 cents and $\$ 1.00$ for. Each one of the eight will be quite hardy, our own selection, and include only the very best varieties and colors, from pure white to dark crimson. This collection must be sent by express. If ordered sent by mail add 25 cents extra to help pay postage. When ordering this collection, please say "Iron Clad Collection of Two-Year-old Roses." No further discount on this offer.

HARDY ROSE, GENERAI, JACOUEMINOT

A rich velvety-crimson; changing to scarlet-crimson. A magnificent Rose, equally beautiful in the bud state or open. This is the best known of all Hybrid Perpetuals, and is without a rival in fragrance and richness of color. It is, moreover, as easy of cultivation as many of the more common varieties, and perfectly hardy. Price, 10c each; large two-year-old plants, 25 c each. (See cut.)

\section{LEOPOLD PREMTIER}

A dark, rich crimson sweet; free bloomer, very beautiful and valuable. Price, $10 \mathrm{c}$ each; large two-pear-old plants, $25 \mathrm{c}$ each.

\section{MADAMOISELLE MARIE RADY}

A clear, bright red, finely penciled with rich maroon very large, full flowers, fragrant and beautiful. Price, 100 each; large two-year-old plants, $25 \mathrm{c}$ each. 


\section{HARDY ROSES-Continued.}

MARIE Flowers very large and of exquisite form; free bloomer. In every way one of the finest Roses grown. Price, $10 \mathrm{c}$ each;
two-year-old plants, $25 \mathrm{c}$.
BAUMANN

A bright carmine.

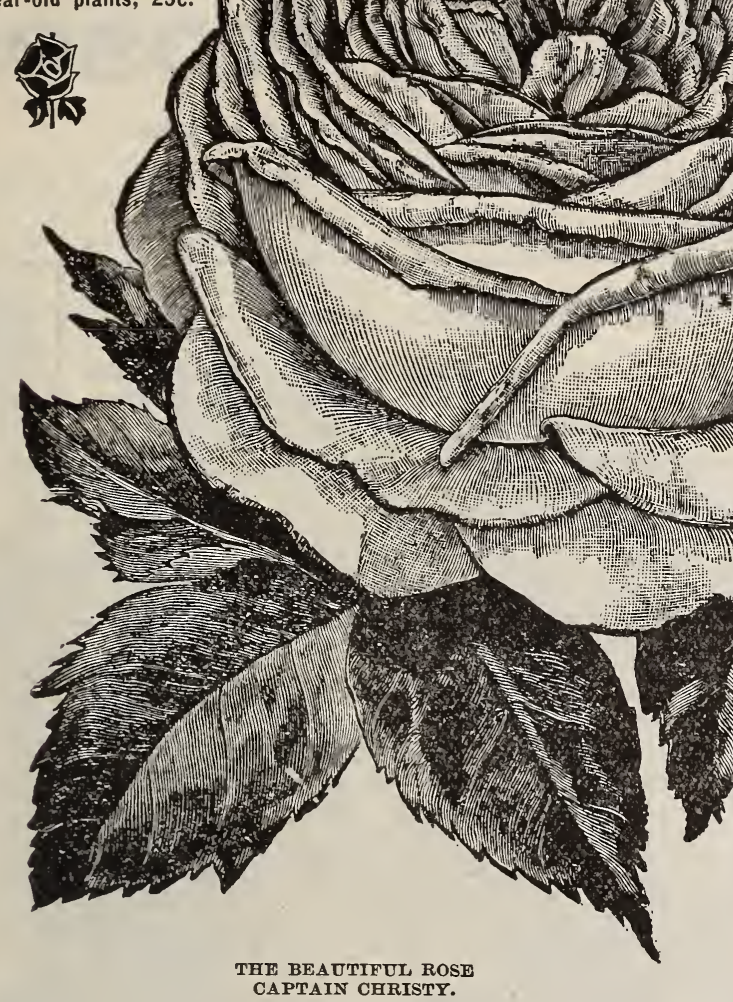

\section{CAPTAIN CHRISTY}

The flowers are of magnificent form, very double and stand erect in their martial bearing. The color is a fresh, delicate pink, with deeper shading in the center of the flower, the whole flower possessing a bright, satiny appearance. A desirable variety. Certainly the most beautiful Rose of this culor we grow. It is a free bloomer. Price, 15 cents each: large two-year-old plants, $30 \mathrm{c}$ each. (See cut.)

\section{DINSMIORE}

It is a vigorous, healthy Rose of dwarf, branching habit, and is simply loaded with flowers all Summer long, being even more profuse than most of the tender ever-blooming Roses. The flowers are large, perfectly double, and of a dazzling scarlet-crimson color, and have the rich, spicy fragrance peculiar to the best Hybrid Roses. We recommend it as being the finest garden Rose ever offered. Prlce, 10c each.

\section{FRANCOIS LEVET}

A very beautiful Rose. Soft, china pink, delicately shaded carmine and blush: large, finely-formed flowers, delightfully fragrant. Price, $10 \mathrm{c}$ each; large size, 25c each.

\section{GENERAI WASHINGTON}

This magnificent Rose is one of the best for general planting. Color a brilliant, shining crimson, very rich and beautiful; flowers are large and perfectly double. A free and regular bloomer. Price, 10c each; large two-year-old plants, 25c each. ROGER LAMBERLIN

A remarkable Rose with irregular edge, much like a double Petunia. The color is glowing crimson throughout, except the edge of petals, which are distinctly marked with a

$$
\text { LADY EMILY PEEL }
$$

Very sweet. white band. Price, $10 \mathrm{c}$ each; two-year-old plants, 30c. with blush. Price, $10 \mathrm{c}$ each; large two-year-old plants, $25 \mathrm{c}$ each.

\section{IOHN FGPPER} Perpetuals ever grown. Flowers are large, very reg.
ular and full. Color a brilliant rose, changing to a bright,glowing pink,shaded with rich scarlet. Very
sweet. Profuse bloomer. Price, 10c each; two-year.old plants, $25 \mathrm{c}$ each.
One of the most relia. ble and satisfactory Hybrid have. It cannot be called deep yellow, but rather a pale shade of chamois or salmon-yellow, deepest at the center, sometimes passing to a rich, creamy white, finely tinted orange and fawn. Price, $10 \mathrm{c}$ each; large two-year-old size, $30 \mathrm{c}$. PERFECTION DES BLANCHES

A finely-formed, pure white Rose; occasionally shows a light flesh when first opening; beautiful shell-shaped petals, evenly arranged. Flowers: of good size and finely formed. Price, $10 \mathrm{c}$ each, large plants, $25 \mathrm{c}$ each.

DOCTOR HOGG

Deep violet-crimson, richly shaded with maroon; shellshaped petals, full, compact form, very double and desirable. Price, 10c each; large two-year-old plants, 25c each.

IOUIS VAN HOUTTE

A rich crimson, heavily shaded with maroon; beautifully formed and double flowers. Price, 10c each; large size, 25c.

NEW HARDY ROSE, MARCHIONESS OF LORNE

This beautiful Rose, dedicated by special permission to Her Royal Highness, the Princess Louise, Marchioness of Lorne, produces flowers of exceedingly rich, fulgent rose color, slightly shaded in the center with vivid carmine. They are large and very sweet, full and of finely cupped shape. large two-year-old plants, $25 \mathrm{c}$ each.

\section{MADAME PLANTIER}

The iron clad white cemetery Rose. This is the old standby, and is unequalled where a hardy white Rose is needed. It bears thousands of beautiful snowy-white fragrant Roses. bears thousands of beautiful snowy-white fragrant Roses.
It is as hardy as an oak. Price, 10c; two-year-old plants, $30 \mathrm{c}$. 


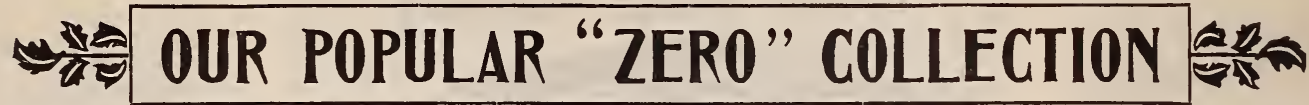

\section{OF

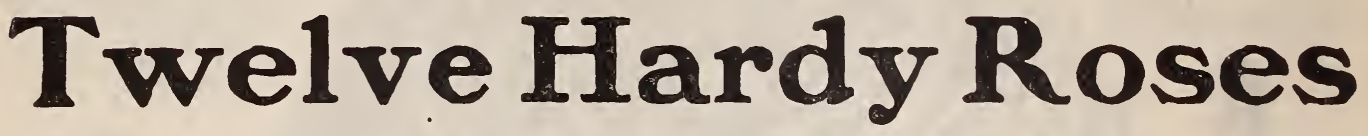

THESE ARE PERFECTLY HARDY AND WILL GROW AND BLOOM

WHERE THE MERCURY FALLS BELOW ZERO. $* * * * \star * *$

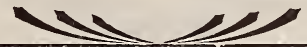

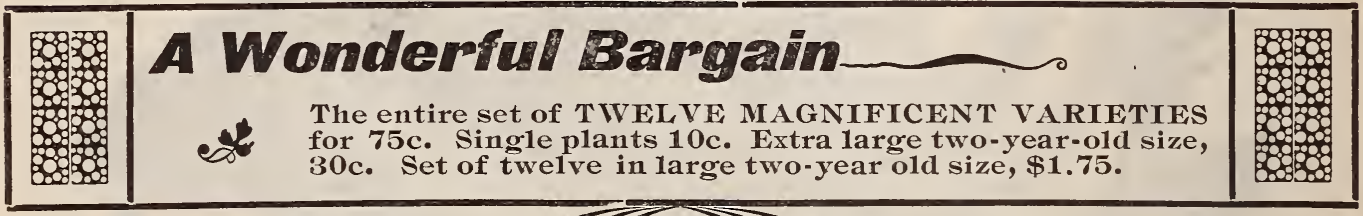

General Jacqueminot.

Too well known to require lengthy description. It still holds first place among the dark red Roses, and is one of the most satisfactory to grow. A rich crimson scarlet, simply a mass of bloom when at its best.

Mad. Chas. Wood.

Continuous blooming and large sized flowers; color rich, bright crimson.

\section{La Reine.}

A beautiful, clear, bright Rose; fine, full form; very fragrant. It is well named "The Queen."

\section{Giant of Battles.}

This is still esteemed as the very best rich red Rose. Very large, double, full and sweet; excellent.

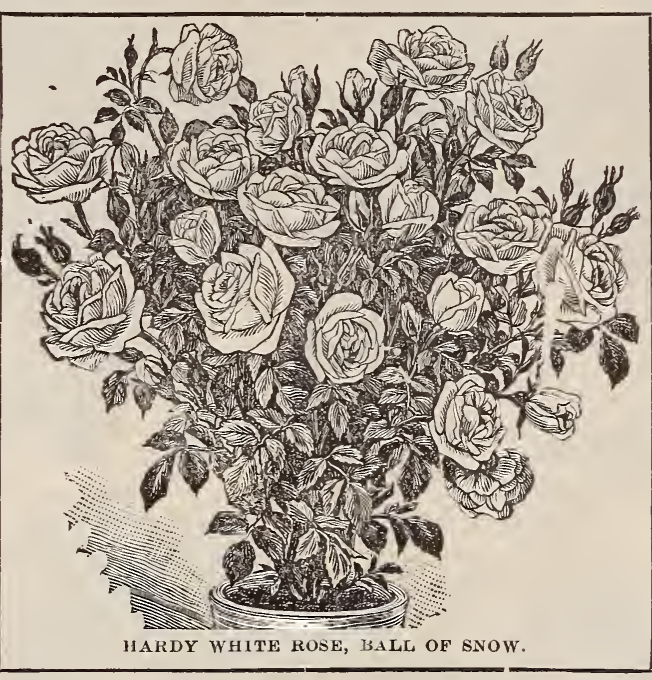

New Hardy Rose...

\section{Countess of Roseberry}

We have in this charming variety probably the most beautiful Rose grown. No othor Hybrid can approach it in its exquisite coloring. Indeed, no one would take it for a Hybrid, as it is as delicate and beautiful in its tints as the most gorgeous of the Teas. The color is satin-pink in the center, and deepens to the outer petals to a bright rose. The feathery shading gives it the appearance of two distinct colors. It has completely capcolors. It has completely caping, and a good grower.

Hardy Rose....

Anna de Diesbach.

(Glory of Paris,) Brilliant crimson, sometimes shaded with bright maroon; long pointed buds, and large, finely. formed, compact flowers, very full and sweet; one of the best.

\section{Ball of Snow. (Boule de Neige.)}

A finely formed pure white Fose; occasionally shows light flesh when first opening. Beautiful shell-shaped petals, evenly arranged; flowers of good size.

\section{Rosy Morn.}

A lovely name and a magnificent Rose. Extra large size very double, full and deliciously sweet. Color an exquisite salmon-rose, shaded with delicate peachy-rose, suffused with soft, rosy-crimson.

\section{Hardy Rose, White Paeoney.}

This Rose was sent us by one of our customers. She did not know the name of it, but called it the White Paeony from its resemblance to that beautiful flower. We have never seen anything in the Rose line like it. The flowers are satinywhite, with a delicate shell-pink tinge. It makes large, spherical balls, and when seen in bloom is not soon forgotten. Very beautiful and entirely hardy.

\section{Antoin Quihon.}

Extra large flowers, very full, compact and regular form. Color a rich, violet-crimson, elegantly tinged and shaded maroon-red; a free bloomer and very sweet.

\section{Hardy Rose, Paul Neyron.}

Deep shining Rose, very fresh and pretty, the flowers large, often measuring five inches in diameter, and it has this merit-though very large, the buds always develop fine, perfect Roses. It is, moreover, a good, strong grower, with nice, almost thornless stems, which almost attain six to seven feet in a single season. We know of no Rose possessing so many good points to recommend it as Paul Neyron. Grown by thousands for its good, free blooming qualities.

\section{Vick's Caprice.}

By far the best striped hardy Rose. The flowers are large and bud and flower are perfect in form; color soft satinypin 1 , distinctly striped carmine. Excellent for cutting. 
Choicest Chrysanthemums $=$ Only 6c Each. OUR GREAT

\section{CHALLENGE COLLECTION}

* OF CHRYSANTHEMUMS. * * * * *

IVE LEAD THE PROCESSION IN CHRYSANTHEMUMS. A glance over our splendid list will convince anyone that this is no idle assertion. We have by far the largest and most complete collection of this most popular flower in the great Northwest, and there is absolutely

\section{NOT ONE POOR GROWER OR INFERIOR SORT AMONG THEM.}

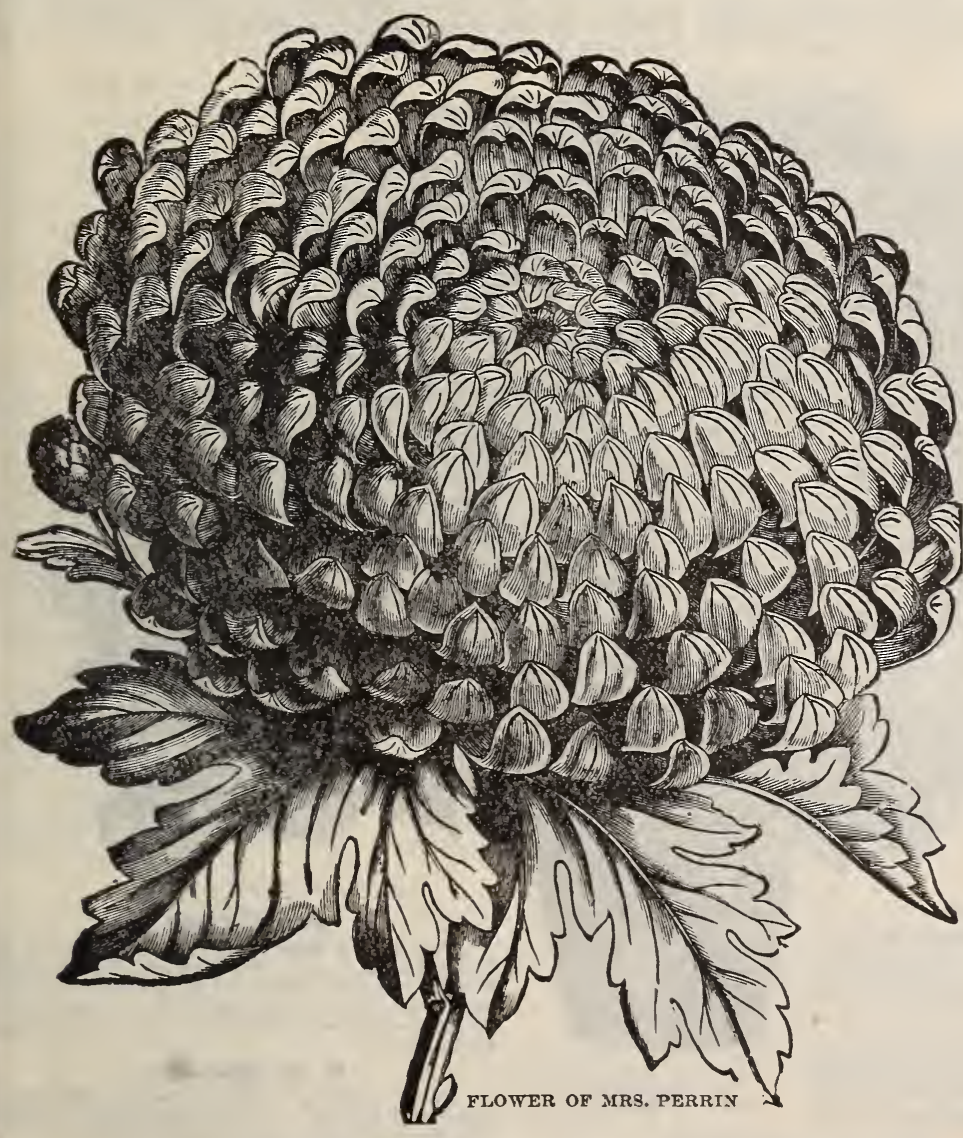

The Lovely Chrysanthemum, MRS. PERRIN.

The flower is of globular form, incurved, full and with a finish as soft as eas!n. Color rose-pink within, glistening pink without. Recognized wherever shown 6o the ideal variety in this color. Received first prize wherever shown as best pink; st 3oston, Philadelphia and Chicago received the most flattering notices. Everyone who has seen it is loud in praise of the color. A wonderfully clear, bright pink, quite free from magenta. The flower is incurving, but quite loosely built.
Geo. W. Childs.

Deep, rich, velvety crimson, with no shade of brown or chestnut; a grand red sort

Mrs. Jerome Jones.

Large, cream-white, incurved Japanese, sometimes showing a tinge of pink; high, round fiower; one of the best Chrysanthemum flowers to grand stem and foliage.

\section{Maud Dean.}

Grand, rosy-pink, of fine build and large size; color extra good; one of the very finest among pinks. Should be in every exhibition collection.

\section{Bronze Giant.}

Exhibition bronze. This is an elegant grower, heavy, stocky stem, clothed throughout in fine foliage. The flower is of immense size, and of great substance; form inand of great substance; form inlargest size, a beautiful rich bronze, or old gold color. Received prem. ium of fifty dollars for best bronze.

\section{G. Moseman.}

$\mathrm{BF}$ far the finest of all varieties yet imported; nine inches in diameter, irregular, incurved petals; buff without and bright red within; flowers large and of robust habit; always a prize winner.

\section{Marion Menderson.}

The earliest of all the large flow. ered yellows, being in perfection by October 10th. The color is a charming bright golden - yellow;

\section{Louise Bochmer.}

This has the same wonderful hair-lilie growth as the white variety, "Mrs. Alpheus Hardy," but differs in color, being a larender-pink, shaded silvery-pinl. Splendidly in: curved. Outside of petals deep rose.

\section{Fisher's Torch.}

Bright fiery-red, the richest shade in Chrysanthemums; large, fine flower.

\section{Red Cloud.}

A grand new dark variety, offered the first time last Spring. The flowers are very large, incurv. ing, and of great substance. One of our very best.

OUR GFNFROUJ OFFFR From this and two following pages you UUR UENERUUS UFFER may select any FIVE for only 25c; any TWELVE for 50c; any TWENTY.SIX for \$1.00. Price per single plant, $6 c$ each. 


\section{OUR CHALLENGE COLLECTION OF "MUMS"-(Continued.) WONLY SIX CENTS EACH ON THIS PAGE.}

\section{Gretchen Buettner.}

This variety has broad, waxy petals of purest white, only center petals show a beautiful pea-green before flower is quite developed. It is quite distinct from any existing sort in this stage. It turns all white when fully open and is full to center.

\section{E. G. HIII.}

Immense flowers; bright yellow, aeeply shaded bright carmine; imported Japanese; a prize winner everywhere; especially good for pots.

\section{TrIumph d'Ex de Marsellles.}

Color deep amber, shaded with a brown-sellow at the cenVery peculiar in form, having long, pendant lower petals, which droop down some three inches. Center high and full of nicely arranged petals.

\section{Joseph H. White.}

Very large white variety, with upright petals, forming a nicely rounded flower of great substance.

Ros/yn.

Superb, clear rose-pink; petals thick and heavy; cupshaped, solid to the center: immense in size, habit, the best; stems stiff and erect, covered with luxuriant foliage.

\section{M/ss Kate Brown.}

The very finest of all the early whites, coming into bloom the first week in October ; fully six inches across. a fine incurved flower with broad petals. first-class disbudded. also beautiful in natural sprays. Highly appreciated in the East.

\section{Mrs. G. J. Beer.}

Immense Japanese bloom, full and deep, rosy - purple color, lighter center. For exhibition only. One of the largest flowered varieties extant.

\section{Modesto.}

This variety has proven one of the finest yellows, and has been a prize winner at every exhibition of Mums. It is intense in color, unsurpassed in size, of an incurved solid form, with full, high center.

\section{Helen Bloodgood.}

A striking variety. Unquestionably the most meritorious pink introduced to commerce, being the first true, clear pink, without a trace of shading of purple or magenta. In form a globe-shaped Japanese, of largest size, with strong and robust habit. Certificate by the Chrysanthemum Society of America at New York and Philadelphia.

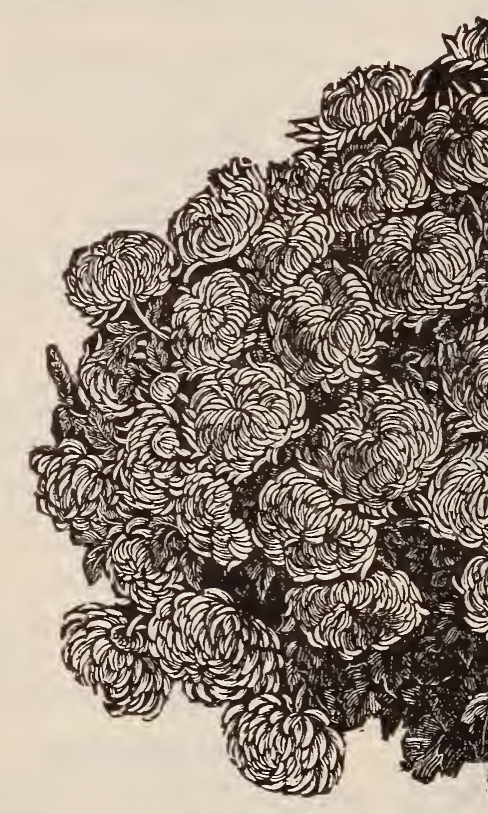

Mrs. Maria Simpson.

Color soft chrome-7ellow. A fine example of the broad petal, incurving Japanese type, showing ne center verv large, fine grower; stiff stems. Silver medal at Philadelphia; certificate at Indianapolis.

Violet Rose.

Of very silky texture, petals long and straight, a fine grower: flower of extra large size and fine color : a fine keeper when cut The color of this fine new variety, as the name indicates, is a beautiful violet-rose. A superb flower.

The Great New Yellow Golden Wedding.

The grandest yellow yet offered. This fine variety swept everything before it at the New York and Philadelphia exhibitions. In color it is a deep, bright gold of shining texture. It is very large in size, the petals are both long and broad and channeled lengthwise. A perfect Japanese incurved of most beautiful form, very free in growth; first-class exhibition variety. (See cut.)

\section{Monarch of Ostrich PIumes.}

Bright creamy-yellow; a Japan novelty of this year. It is quite large for this type; of beautiful form and finely in curved. Those who have been buying Ostrich Plume varieties will be much pleased with it.

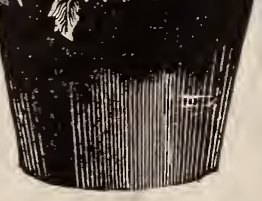

THE WONDERFUL GOLDEN WEDDING.

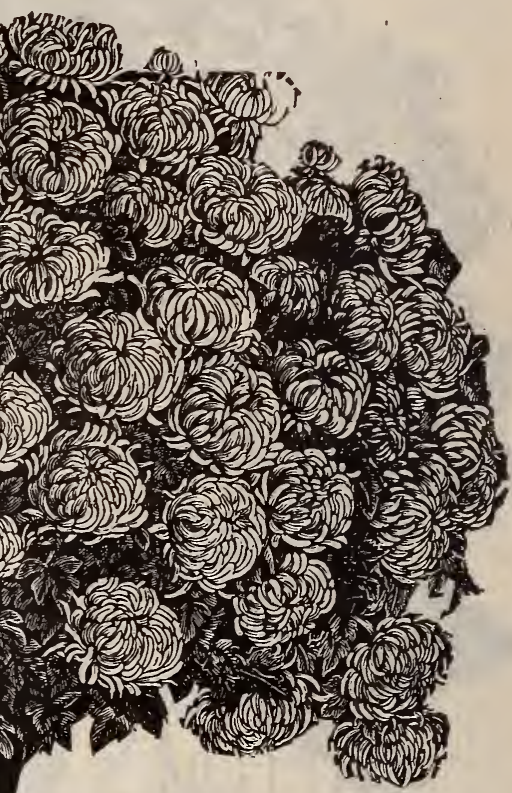

Signal Light.

Pale yellow incurved Japanese. Reverse of ower petals tipped red bronze: finely built flowers; as truly incurved as a Chinese; solia and perfectly double, lasting a long time. Habit very dwarf; foliage beautiful and right up to bloom

\section{B. Whitnall.}

Large regular Chinese; outer petals re curving, forming a perfect globe. Color soft, velvety-maroon; reverse a shade lighter.

\section{Marie Louise.}

A beautiful recurving white, with slender, interlacing petals, forming a plumiy globe. Received Columbian medal at the Chicago show. Not of enormous size, but of good substance; stems slender and stiff; foliage elegant; a model for cut flowers.

\section{Preslident Wm. R. Smith.}

Color of Daybreak Carnation; a pure self-pink; very heavy in subtance on stiff stems. Tery free in growth form of the flower is very beautiful in ail its stages; it opens with a center incurving in a circle enclosed in broad outer petals; becomes rounded and deep; perfectly double; a splendid keeper. 


\section{OUR CHALLENGE COLLECTION OF "MUMS"-(Continued.)

\author{
oNONLY SIX CENTS EACH ON THIS PAGE.
}

\begin{abstract}
Getfysburg.
This is a deep crimson variety, and excels in its color as Golden $W$ edding does in yellow. Deep, rich crimson, which in the flower itself is soft and velvet-like. The outer petals are broad and drooping, and have a lustrous sheen in the sunlight. The form flat, with drooping outer petals, which gives it a rery graceful appearance. This is the popular form, and combined with the splendid color, stamps Gettysburg as a Chrysanthemum of rare merit.
\end{abstract}

\section{Per/e Lyonnalse.}

Bright, clear, golden-yellow, somewhat plumed, quite full; one of the very finest, of medium size; beautiful, globular form; new.

\section{Ada spaulding.}

A striking variety; habit sturdy and robust; color a rich, deep pink, shading in upper portion to the purest pearlwhite. A warded silver cup, two medals and three certificates.

\section{Leopard.}

Quite distinct in its strle; the only spotted variety. The ground color deep carmine, spotted white.

\section{Niveus.}

A grand snow-white variety. Center irreg. ularly incurving, with outer petals reflexing nearly to the stem. Constitution robust,foliage large and abund. ant, while the keeping qualities of the flowers are unsurpassed.

\section{Minerva.}

An exceedingly attractive, bold, massive flower, very large, incurred, the outer petal drooping, forming al most a perfect flower of the most ririd clear sellow, with extra good fem and fine handsom inches of the flower. Certifieates of merit at New York and Philadelvhia shows.

\section{Prest. McKinley.}

This is one of the $g \mathrm{randest}$ of all the lighter shades of pink and is the finest of al varieties of this color. In size one of the largest, elegant in finish solor exquisite. Early midseason. One of th finest for bush form.

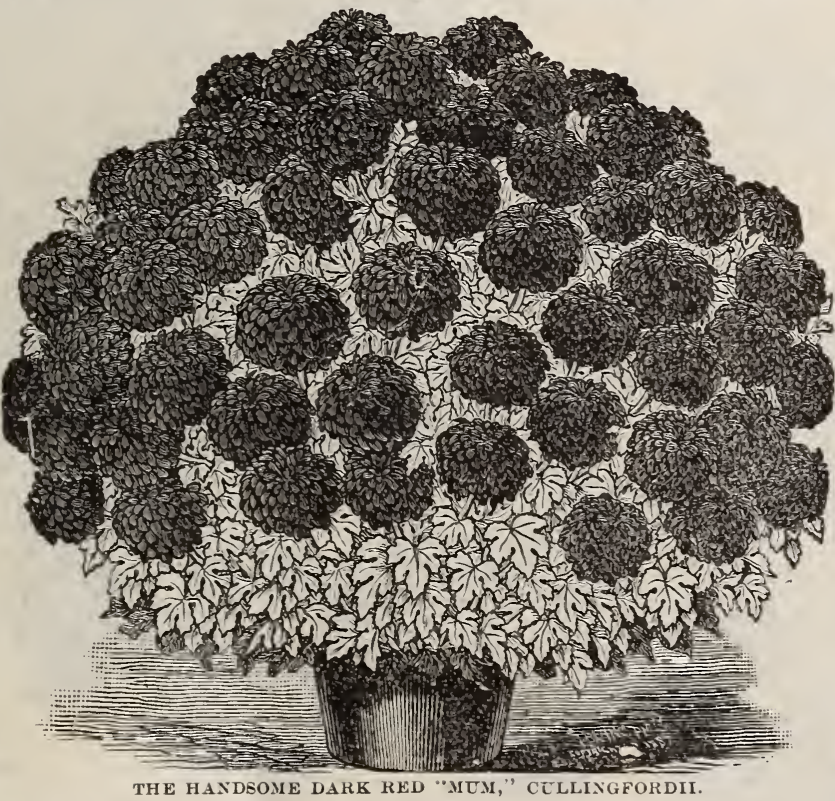

Maude Dean.

An immense pink variets. finely incurved. petals broad. hell-shaped. One of the largest flowers exhibited in the Fall shows. Almost a pure shell-pink. Received silver medal at Philadelphia, and awarded certificat es of merit at New York Philadelphia, and
and Philadelphia.

\section{Mad. Bergman.}

A grand new Chinese variety of dwarf habit, very full in growth, and with large, dark-green foliage. The flowers are large and globular, with reflexed petals. Color pure white, center shaded with light yellow. Especially valuable because it is the earliest of all the large flowering sorts.

\section{Judge Hoitt.}

The greatest break in seeding of recent years; an Anemone full eight inches across; color pale pearl-pink; the outer petals are broad and incurving.

\section{Mrs. Georgiana Pitcher.}

A yellow variety that will make a reputation for itself. Habit dwarf, flowers incurved, of good size, fine color, of great substance; a magnificent variety.

\section{The Queen.}

A grand double white, of fine form and great substance very rounded in form, incurving and full. Attracted a great deal of attention at Madison Square, where it was awarded first premium for best white.

\section{Bronze Giant.}

Exhibition bronze, This is an elegant growar: heavy, stocky stem; clothed throughout in fine foliage. The flowe is of immense size, crowded with petals, which are stiff and of great substance; form incurving; a most imposing bloom of largest size; a beautiful rich bronze or old gold color. Received premium of fifty dollars for best bronze.

Mrs. E. G. Hill.

One of the earliest of all the large flowering sorts. Flow. ers very large, seven to eight inches across; full to the center. A grand incurved splere when fully expanded. Color delicate pearl-pink; extra fine.

\section{Mrs. Ceorge Gordon.}

Light, "primrose-yellow, incurved very gracefully in appearance; the best of its color; mid-season

\section{Crystal Queen.}

A first-class variety; large, nicely flnished snow-white flower of rounded form, full to the center; incurved, pointed petals, and of great substance. Probably the best and most useful of the many white varieties.

\section{Cullingfordii.}

Brilliant crimson, shaded scarlet; flowers of a rich, velvety texture. One of the brightest and most distinet of all the dark colored sorts. Petals finely re-

Miss Dalskovi.

(The Pink Ivary.)

An immense incurv. ed rariety. Clear, bright pink; fine roundwith deep, strong foliage. The grandest of the extra early clear pink varieties.

\section{President}

Wm. R. Smith.

Color of Darbreak Carnation, a pure selfpink; very heary in substance, on stiff stems. The form of the flower is very beautitnl in all its stages; incurving in a circle enclosed in broad outer petals; it gradually assumes the true Japanese form, rounded and deep and this gradually changes to the informal reflexed; perfectly douhle: a sp'endid keeper; especially fine for cut flowers and exhibition blooms. Yellow Good Graclous.

Largest jellow in existence. This magnificent new Chrysanthemum was exhibited last Fall, measuring over fifteen inches in diameter, and is, without exception, the largest jellow Chrysanthemum ever introduced. The color is a deep golden-rellow, very bright. Very massive in build. A grand addition to our already fine class of rellows.

\section{L'Enfant Des Deux Mondes.} (Child of Two Worlds.)

Pure white. This grand white sport from L. Boehmer was well received, having many admirers at the shows. Like the parent, it is a strong grower of good habit, and is considered the best white of the hairy type, and well deserves a prominent place in any set of this peculiar style of the Chrysanthemum

\section{The Pond Lily Chrysanthemum, Pitcher and Manda.}

This is the most wonderful Chrrsanthemum ever introduced. There is nothing that has ever been offered that in any way approaches it. Who ever heard ot Chrysanthemum having two distinct colors in one flower? But Pitcher and Manda has. The outer five or six rows of petals are pure white, of dahlia-like form: center is a bright, deep yellow, the two colors being sharply defined. A most distinct novelty. 


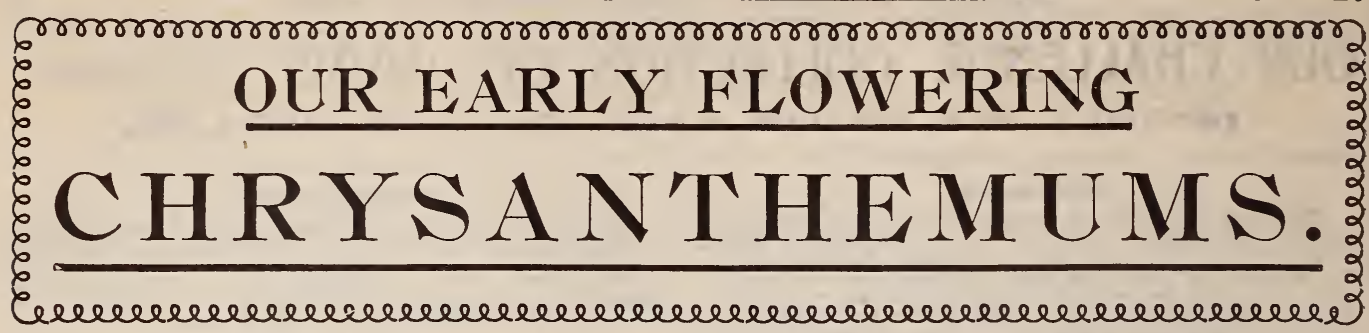

OUR SPECIAL OFFER.-We will send the full set of ten early "Mums" for only 50 cents. Any five for 30 cents.

WE GET many inquiries for Chrysanthemums that bloom early. For the benefit of those who want early "Mums" we here offer a very fine collection, embracing the choicest sorts and a wide range of color.

\section{IVORY}

Unexcelled for pot culture or cutting; pure white flower of exquisite form and finish. Has been shown in grand shape at all recent exhibitions; it is especially noticeable for its grand globular form, its dahlia-like petals and absolute purity of color.

\section{VIOLESCENT \\ Violet amaranth, reverse silvery white, enormous flowers of great beauty. This is one of the grandest early flowering va- rieties we have, and the color is distinct from all others.}

\section{MISS DALSKOV}

The latest and greatest acquisition to the Chrysanthemum world. We have thoroughly tested this grand new variety and we cannot say too much in its favor. We had single blooms last Fall that measured ten inches across. In color it is a beautiful pink, entirely distinct from any pink Chrysanthemum yet exhibited.

\section{MISS KATE BROWN}

One of the very finest of all the early whites, coming into bloom the first week in October; fully six inches across; a fine incurved flower, with broad petals; first-class disbudded, and also beautiful in natural sprays.

\section{MRS. HENRY ROBINSON}

A perfect form, of the Queen of England type, of exceptional merit, large and well finished. An early white, blooming with us October 5th. Fine substance and very lasting.

\section{GLORY OF THE PACIFIC}

It is of maynificent size and depth, with broad petals which finely reflex, showing the clear pink color to excellent advantage. A pink of large size and good form. This variety will delight every grower.

\section{CULLINGFORDII}

Reflexed. Ex. ceedingly brilliant crimson, richly shaded with scarlet. Florets of a beautiful, rich, velvety texture. One of the very distinct and noted sorts. This is one of the finest red Chrysanthenums in existence, and too much can not be said in its praise.

BENJ. GIROUD

Is the richest deep crimson variety we have ever seen and excels in its color as Golden Wedding does in jellow. The color is of the richest velvety-crimson, which in the flower itself is soft and velvety-like. It is, without doubt, the best Chrysanthemum of its color. The flowers are
the richest of all. ellormous in size, while the color is the richest of all.
Winner of nine premiums and certificates. Blooms in October.

\section{MARION HENDERSON}

We cut the first flowers on October 10th, several days weîore any other large yellow was ready, and had perfect flowers to cut a month later. The texture of the flower is such that we have never seen it in the least affected by damp, although other varieties alongside of it were badly affected. We have never seen a symptom of any disease on it. This grand variety will be invaluable for early cut flowers, and we believe, will occupy the same position among early varieties that Golden Wedding does among the late ones.

\section{MME. F. BERGMANN}

Still the finest of all the early whites; large in size, com. ing into bloom October 10th; excellent for pot culture for early flowers. 


\section{Che Beautiful 0strich Plumed Chrysanthemums}

\begin{tabular}{|l|l|l|l|l}
\hline & The best of the choice and rare. Price, 10 cents each, except where noted. The \\
entire collection of eight splendid sorts for only 50 cents. The term "Ostrich \\
Plume" is applied to this type on account of the featlery growth with which \\
the petals are thickly covered.
\end{tabular}

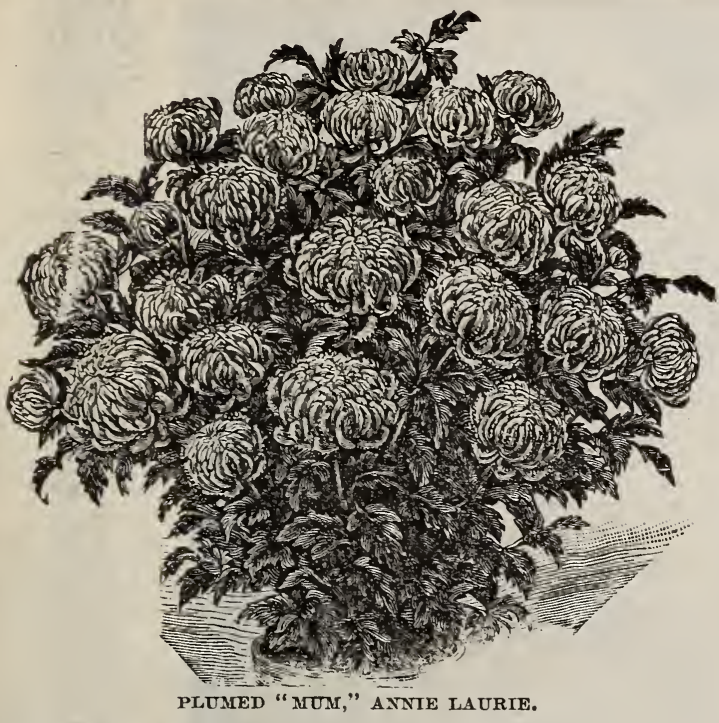

Our Beautiful New Ostrich

Plumed Chrysanthemum,

\section{ANNIE LAURIE}

A lovely new plumed Chyrsanthemum, quite distinct from any other plumed variety. The flowers are very large, color a beautiful creamy white-tinted pink, and is completely covered with the soft hair-like growth peculiar to the plumed varieties. It is a very strong grower and in every way a valuable addition to this beautiful class. Price. $15 \mathrm{c}$ each.

The Latest Novelty in

Ostrich Plumes, - -

\section{GOLD DUST}

Pure golden yellow, very plumy, very full, shows no center at all, finely incurved. Color very brilliant. Received honorable mention at Chicago, where it was described as a decided improvement on Yellow Ostrich Plumes. Price, 10c. each.

The New Ostrich Plume,

\section{MONARCH OF OSTRICH PLUMES}

Bright chromeyellow. A Japar novelty of this year. It is quite large for this t5pe; of beautiful form and finely incurved. Those who have been buying Ostrich Plume varieties will be much pleased with it. Price, $10 \mathrm{c}$ each.

The Pink Ostrich Plume Chrysanthemum,

\section{LOUIS BOEHMIER}

Has a wonderful hair-like growth or excrescence. Color a most beautiful shade of lavender pink, shaded silvery pink on the ends of petals. Flowers splendidly incurved, inside of petals deep rose. For evening wear the Louis Boehmer will be sure to be in demand. Flowers enormous, and it is absolutely free from any taint or blight. Awarded silver medal at Philadelphia. Price, $10 \mathrm{c}$ each.

The Charming New Yellow Ostrich Plume,

\section{PERLE OF LYONAISE}

Bright, clear, golden-yellow, somewhat plumed, quite full, one of the very finest; of mediumsize; beautiful globular form; new. Price, $10 \mathrm{c} \mathrm{each}$.

The Enormous New Pink Ostrich Plume Variety,

\section{MIRS. HIGINBOTHAM}

Enormous bright pink, broad-spreading Japanese variety; with extremely wide cupping and incurving petals which are covered with granular hairs. Was shown at Chicago exceeding eleven inches in diameter, and reported as the largest and best hardy variety ever exhibited. Habit, stem and foliage perfect, without any of the weakness usually accompanying hirsute varieties. Awarded certificate at Chicago and Philadelphia. Price, $10 \mathrm{c}$ each.

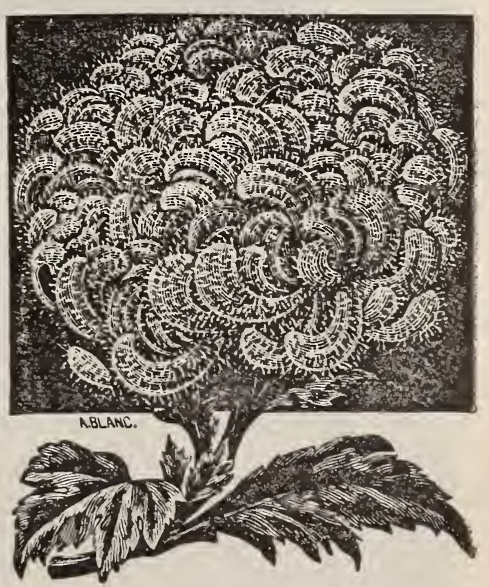

FLOWER OF ENFANT DES MONDES.

(One-fourth natural size.)
The New Wbite Ostrich Plume Chrysanthemum,

\section{ENFANT DES BEAUX MONDES}

(Child of Two Worlds.) Pure white, strong grower, of good habit, and is considered the best white of the hairy type and well deserves a prominent place in any set of this peculiar style of the Chrysanthemum. Price, $10 \mathrm{c}$.
New Rosy-Blush Ostrich Plume Chrysanthemum, WM. FALCONER

The color is an exquisite shade of rosy blush, changing to a delicate flesh pink as the flowers advance in age. The soft, feathery growth peculiar to the "Ostrich Plume" class is even more pronounced than in any of its predecessors. A unique and beautiful variety. Price, $10 \mathrm{c}$ each. 


\section{NEW CHRYSANTHEMUMS OF 1901.}

THE NEWEST AND CHOICEST VARIETIES EXTANT.
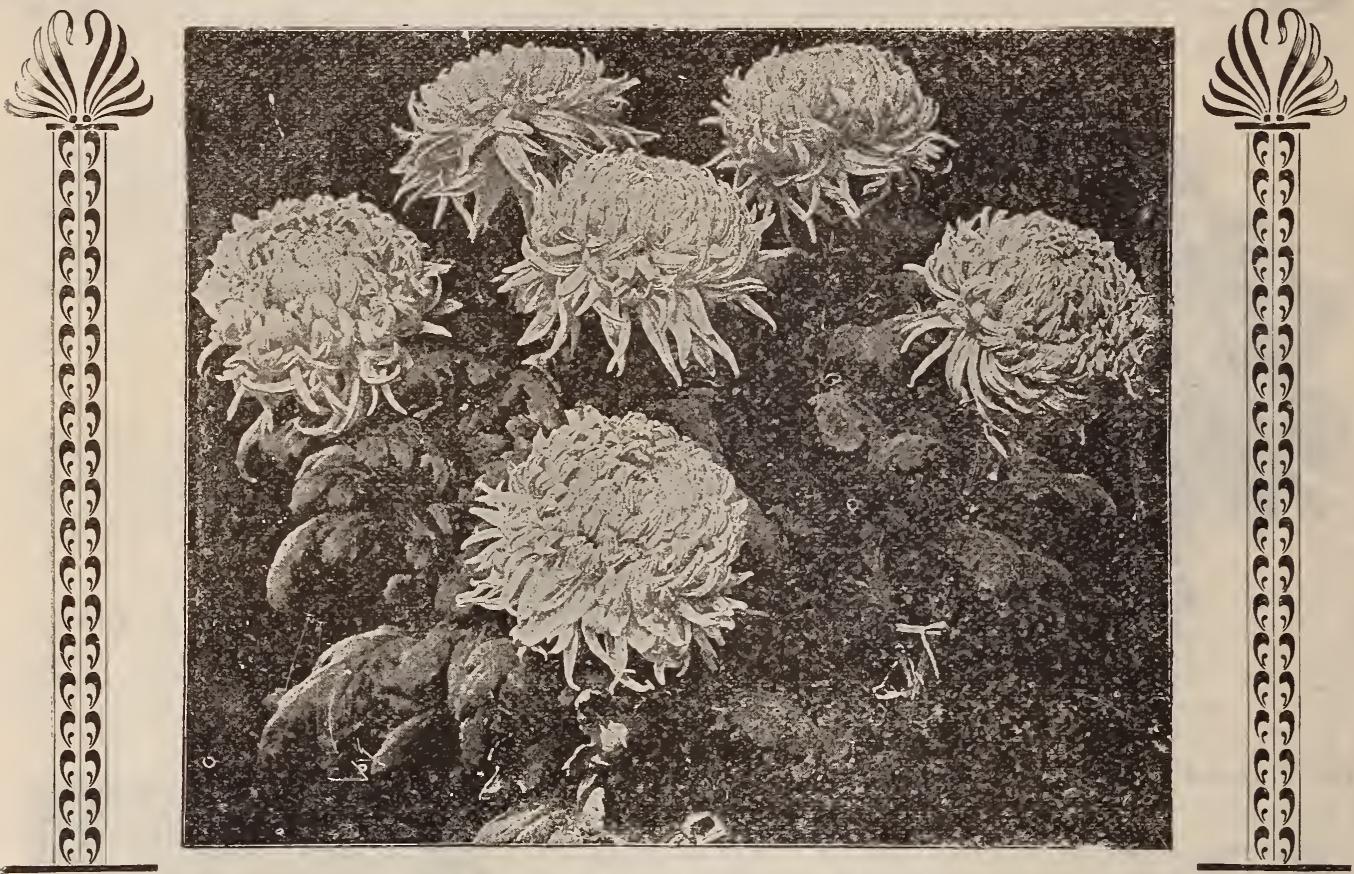

THE WHITE GIANT "MUM," TIMOTHY EATON,

THE CHRYSANTHEMUMS named on this page are the choicest productions from all exhibitions and sources for the year 1901. Our patrons can rely on them being each and every one the very choicest color, as awards are not given until the judges are satisfied that they are better than any existing sorts. So if you wish to be up to date, and have the very best, order this set.

\section{PRICE, 15c EACH, EXCEPT WHERE NOTED; THE SET OF 10 FOR \$1.00; ANY 5 FOR 50c.}

The sensatien of the year is the giant white variety,

$$
\text { * * TIMOTHY EATON. * * }
$$

The awards given it in 1900 were:

The Chrysanthemum Society of America's silver cup for any best ten blooms on exhibition.

American Institute, $\$ 25.00$ premium, ?

New York Hort. Soc., silver cup,

Two First Premiums,
Two Silver Medals, Philadelphia.

Also, National Society's Certificate, scoring 92 points.

It is the largest globular Japanese incurved variety yet raised; form, round and perfect; stem stiff, nicely clothed with foliage; color, creamy white; texture good, making it a splendid keeper and shipper, for blooms shipped from Canada, and awarded premiums at the Philadelphia show, were the same blooms receiving the Society's certiflcate when examined on Saturday after the show had closed. Price, 25c.

\section{The Giant New Red Chrysanthemum,}

\section{* * * MALCOM LAMOND. * * *}

This is a grand new exhibition red. The flowers are of massive size, reflexed, with broad, stiff petals. Color a deep, rich, flery, velvety red. It is, without doubt, the best Chrysanthemum of its color. The flowers are enormous in size, anthemum of its color. tomers to try this variety, as it will not disappoint $50 u$

Received Chrysanthemum Society's certificate. 25c each.
Effie Dean-A beautiful sport from the fine commercial sort, Maud Dean. The color is a charming ivory-white, beautifully veined; when flower is fully developed, shows the carmine center, making it very effective.

Mrs. H. Weeks - An immense flower, with broad clawlike petals, incurving to form a globe of white, a few outer petals reflexing; has made a sensation in England, and in our own country last Fall appeared in fine shape at most of the principal shows.

Mrs. S. T. Murdock-One of the finest varieties in cultivation; nice glistening pink, fine globular bloom of rather short, incurving petals; early mid-season, stem and foliage perfect; a fine keeper.

Mrs. John J. G1essner-A light yellow, very distinct in form ; broad petals opening in a whorl, which, when matured, assume a convexed form; tips turning backward and twisting in all directions.

Mrs. O. P. Bassett-Magnificent flower; outer petals broad and soft cream color, tinted with carmine; attracted large attention at Chicago shows.

Robert B. Laird-An incurved Japanese variety. Solid and globular petals, broad and deeply grooved, inside orangered, outside old gold. A monster variety.

Bessie Hollis-A magnificent golden-yellow variety, with straight, flat, spreadin $\%$ petals. An extra large flower, completely double and of great substance.

Mrs. Martin A. Ryerson-A pure white, petals narrow : the center builds up with interlacing, incurved petals, making a very high flower; distinct in form. 


\section{OUR ROYAL COLLECTION OF}

\section{Beautiful Fuchsias}

We have selected Twelve of the very best Double and Single Fuchsias from our large collection and will send the entire set for a remittance of 75 cents, or any seven for 50 cents.

\section{THEY ARE BEAUTIFUL SORTS. TRY THEM.}

PRICE PER SINGLE PLANT 10G, EXCEPT WHERE NOTED.

Grandest Double White Fuchsia in $5 x$ is tence, White Giant-The largest and best white furm and very double. Color a pure white. Tolor a pure white. cellent Winter bloomer. Price, $15 \mathrm{c}$ each.

Mrs. G. Rundel - A much improved Earl of Beaconsfield tube and sepals blush. hite; corolla rich range; a very good variety; single. 10c.

Lovel y-Another fine market variety. $\mathrm{Tube}$ and sepals white; corolla single; brilliant crimson;

Gr 1 o i $r$ e $D$ e $s$ Marches-Tube and sepals bright reddishcrimson, corolla pure white. A fine double flowering sort; splendid habit of growth. Price, $10 \mathrm{c}$ each.

Orifla m meTube and sepals clear crimson; large, single red corolla; beautifu amaranth. $10 \mathrm{c}$ each.

Black PrinceMakes a shapely bush and is probably the freest in blooming. We have seen specimen plants six feet in height and four feet across loaded with thousands of its bright buds and blossoms of a beautiful waxy-carmine or pink color. Frice, $10 \mathrm{c}$ each.

Phenomenal The largest double Fuchsia,single bloom are actually 2 inche in diameter under good cultivation; tube and sepals reddishcrimson ; corolla clear azure - violet flaked red. Price, $10 \mathrm{c}$ each.

Dolly VardenFlowe r s globular dark red tube and sepals, with rich, dark blue corolla. Price,

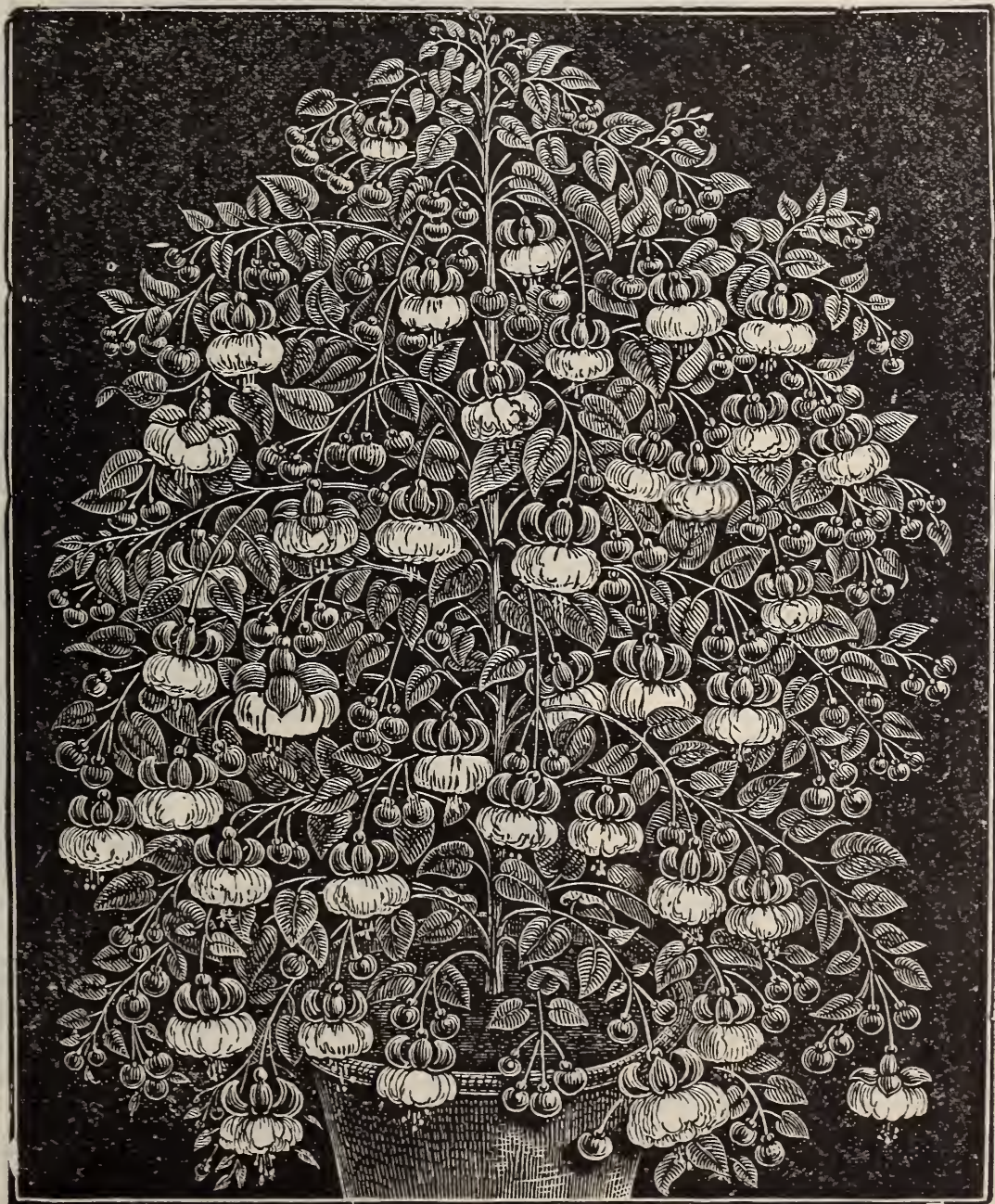

BEAUTIFUL WHITE GLANT.

Wave of Life-This is a beantiful variety, with golden. yellow foliage. Sepals vivid scarlet; corolla bright violet. Price, $10 \mathrm{c}$ each.

Em peror, or Single Phenomena1-This new Fuchsia is by far the largest of all the ingle flowering rieties. It is an exceptionally strong grower, bearing immense blooms of a very rich, dark purple. It ranks among the singles the same as Phenomenal does among the doubles. Nice strong plants, $15 \mathrm{c}$ each.

The Beautiful Golden - Leaved Double Blue Fuchsia, Avalanche-An early flowering variety with golden foliage; large double purple flowers. $10 \mathrm{c}$ each.

Speciosa-Corolla scarlet; sepals blush. One of the best blooming $\mathbf{v}$ arieties for Summer or Winter. Price, $10 \mathrm{c}$ each. 


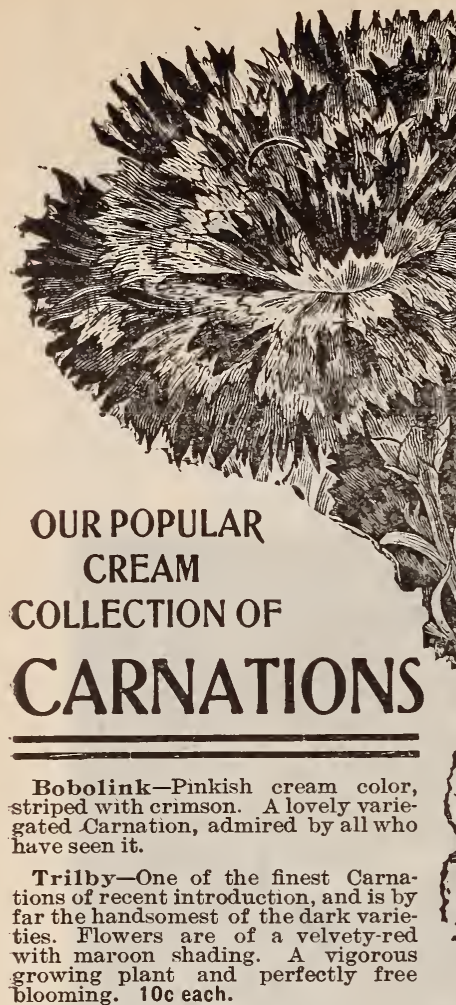

Daybreak-More widely known than great favorite as a cut flower and merits the grand reputation it has the world over. flowering and long stemmed.

Portia-A favorite everywhere, for it desirable shade of bright scarlet. The flowers are of good size after being cut. One of our most valuable varieties.

Silver Spray-A fine, white Carnation, flowers large, full and fragrant. The flow. double.

Em press-Magnificent, rich crimson, base of petals fiery scarlet; large, perfectly

E1dorado-A yellow of free blooming finely formed flower of fair size, ver. free. pink; almost a Picotte in marking. The flower retains its yellow cclor under artificial light, unlike most yellow varieties.

Armazinda-Pure white, lightly penciled with scarlet. Fine, large flowers of feet in length. Price, 10c each.

Flora Hil1-Unquestionably the grandest white Carnation to date. Very free in rounded form, highly clove-scented and all borne on very long stems. Price, $10 \mathrm{c}$ each.

Rose Queen-One of the best pink varieties for all uses. The plant is bushy arid up by stiff, erect stems. Color, a soft pure rose.

The entire Cream Collection of 10 very choice Carnations only 60 cents. Per Single plant, 8 cents each, except where noted. No discount on this collection. In ordering, please sav "Cream Collection."

36
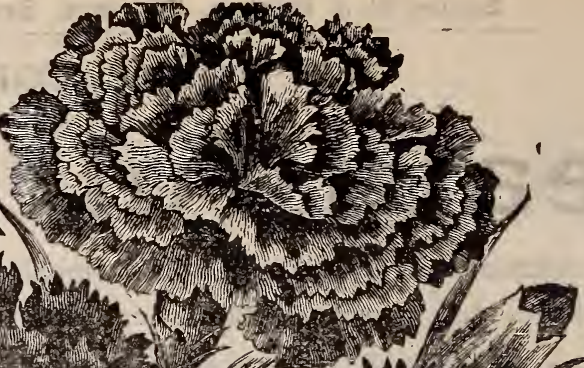

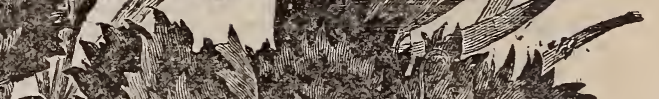
a.

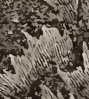

$r$ in

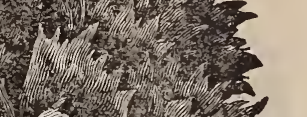

1.

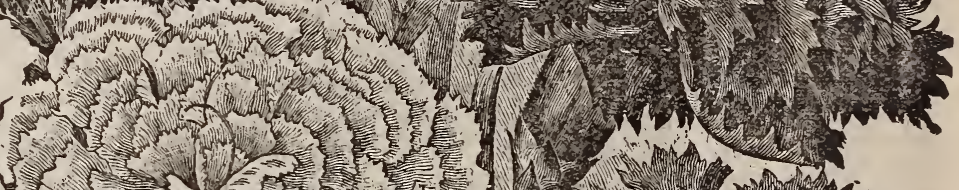

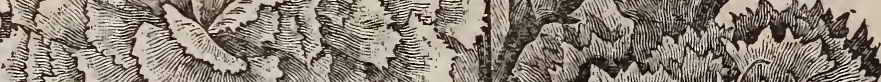

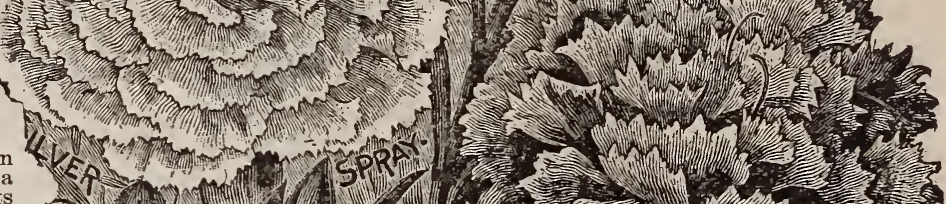

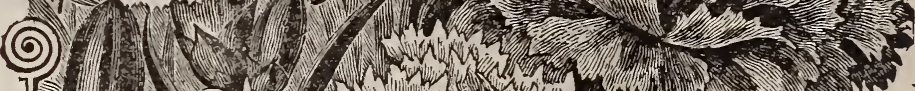
(1) A N

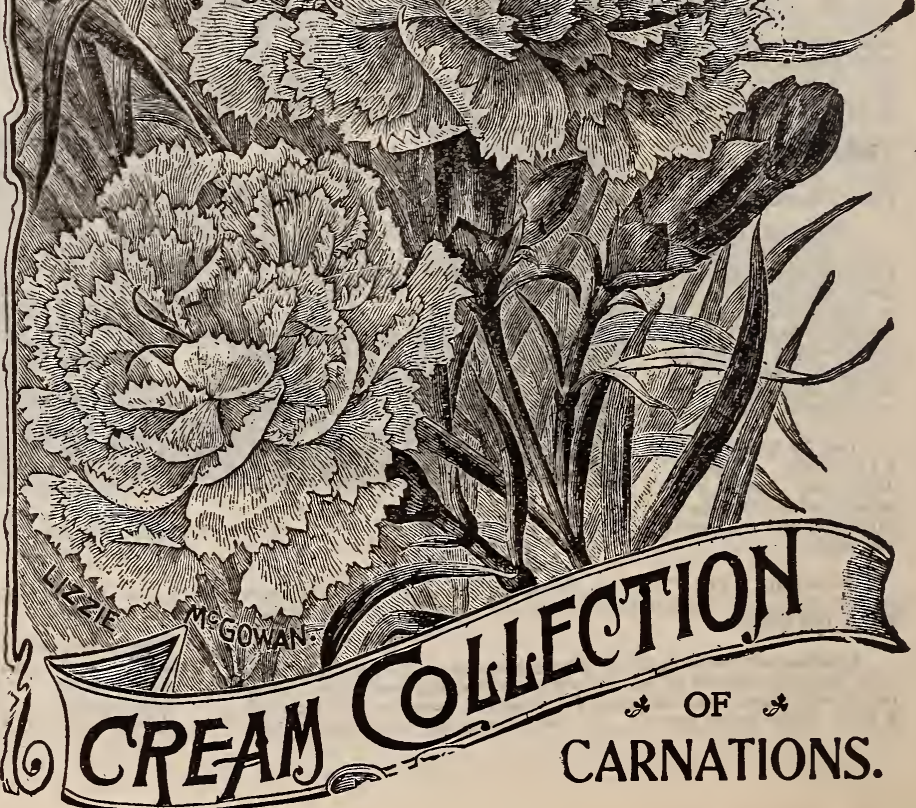




\section{The Up-to-Date Set of New Carnations.}

This grand set of nine new Carnatlons embraces the very choicest and newest, some of them being offered for the first time this spring.
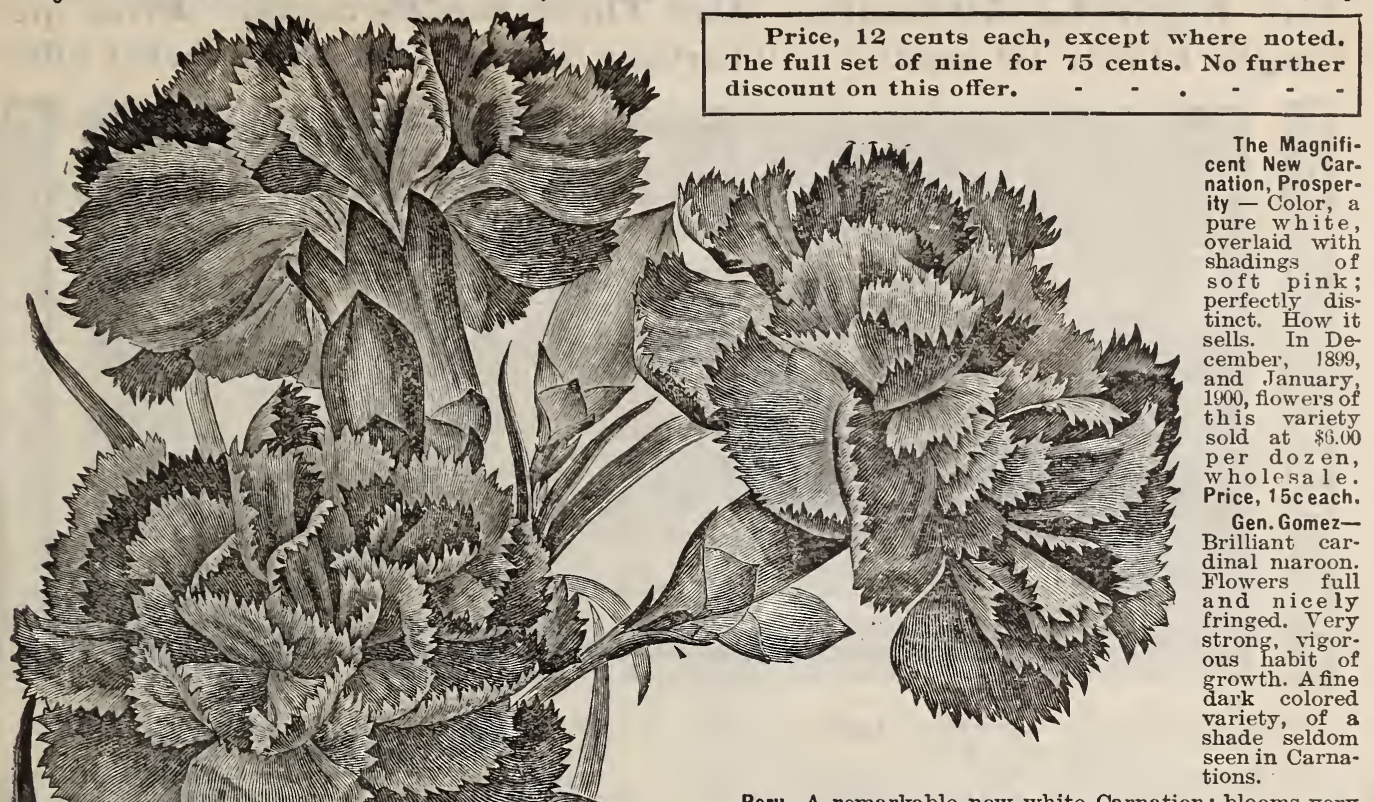

Peru-A remarkable new white Carnation; blooms very early on strong stiff stems and continues to bloom the entire season. Flowers large, of fine shape, and very fragrant.

The Marquis-Blooms continuously with immense bright pink flowers of clove-like fragrance. This grand new sort bids fair to be one of the most popular Carnations out. Price, $15 \mathrm{c}$ each.

Elma-This grand sort will rank with the very finest of exhibition or commercial varieties, and we predict a cer tificate for it at the February Carnation Meeting; the flowers are full and rounded and very large, the color is bright pink with silvery sheen; the stem is long, upricht, but not rigid alyx good a strong free grover and a free bloum variety will prove very popular; it has every requisite of a first rate sort.

Gov. Roosevelt-(Ward.) Rich, brilliant, scarlet, shaded maroon; exceedingly free and constant bloomer, producing good-sized flowers with good stems; claimed by the raiser to be the best all-around oodmems, claimed by the raiser to winner wherever it has been shown. Price, $15 \mathrm{c}$ each.

California Gold-(Hill and Craig.) Bright glowing yellow with scarlet stripes; very nice form, of fair size; exceedingly free flowering, not a cropper, but a continuous producer. For those wanting a good reliable yellow this will fill the bill.

Genevieve Lord-Soft pink, very free, of good form and a general favorite with all who see it. An all-round good variety.

Dorothy-(Mrs. Grave.) One of the very best commercial pinks set introduced; bright clear pink about the shade of Scott, fully as free flowering, but larger and THE LOVELY CARXATION, PROSPERITY. of excellent form, and a grand keeping variety, with extra good stem. This we consider one of the best money makers for the commercial grower ever offered.

\section{Brilliant New Geraniums of Last Year's Introduction.}

Here we offer the very newest and richest colored Geraniums yet introduced. They are simply magnificent in their rich coloring and freedom of bloom. They are entirely new, this being the first time some of them have been offered to the public.

Jean Viaud-Has been strled "Pink Beaute Poitevine," and is an entirely new color in this useful class of Geraniums. The plant is of low, stocky growth and very prolific bloomer. Flowers in immense size trusses on rigid stems. Color, clear, bright rose, excellent for either bedding or pot culture. Will be planted in large quantities as soon as its good qualities become known. Price, $15 \mathrm{c}$ each.

Mme. Landry-(Double.) One of the choicest and most beautiful ret added to the Bruants. Very free and constant in bloom throught the season. Trusses large, and florets of the finest size and circular in form. Color, clear salmon, center shading to copper, with a white eye. 'Very distinct, and one of the best. Price, $15 \mathrm{c}$ each.

M. Canovas-(Double.) Immense trusses of very dark, velvety scarlet, with dark crimson shadings. Flowers large, on rigid stems. A fine, free grower, and free in bloom. Price, $15 \mathrm{c}$ each.

Mme. J. Cibiel-(Single.) Flowers of the very largest size, round and perfect, center bright pink, white eye, large white border. Plant compact and free. Beautiful, fresh color. Does finely indoors and out. Price, $15 \mathrm{c} \mathrm{each}$

Fine, Fancy, Double Mme. Goy-ux-Light rosy pink, with large white blotch in the center of the flower; a delicate and beautiful color. One of the prettiest of the double aureoles, because the colors are absolutely bright and clear. Very free in bloom, and stands the sun flnely. Yery valuable in fancy bedding, a nice dwarf grower, with compact foliage of light green; free and vigorous. Price, $15 \mathrm{c}$ ea. $\mathrm{h}$.

Marquis de Castellane-Plant low growing and sturdy, flowers bright cherry red. Will be planted everywhere Double. Price, $15 \mathrm{c}$ each.

Andrew Lang-Glowing scarlet, with large white blotch on the two upper petals, the center suffused with carmine; the most brilliant contrast of colors yet found among the aureoles united with a form nearly circular. Beds nicely. Price, $15 \mathrm{c}$. A GRAND OFFER. -We will send this brilliant collection of seven new Geraniums for a remittance of only 75 cents. 


\section{Best Double Geraniums for $\$ 1.00$} Any Eight for 50 cents. Any Three for 25 cents. Price per Single Plant, 10 cents. No further discount on this liberal offer.
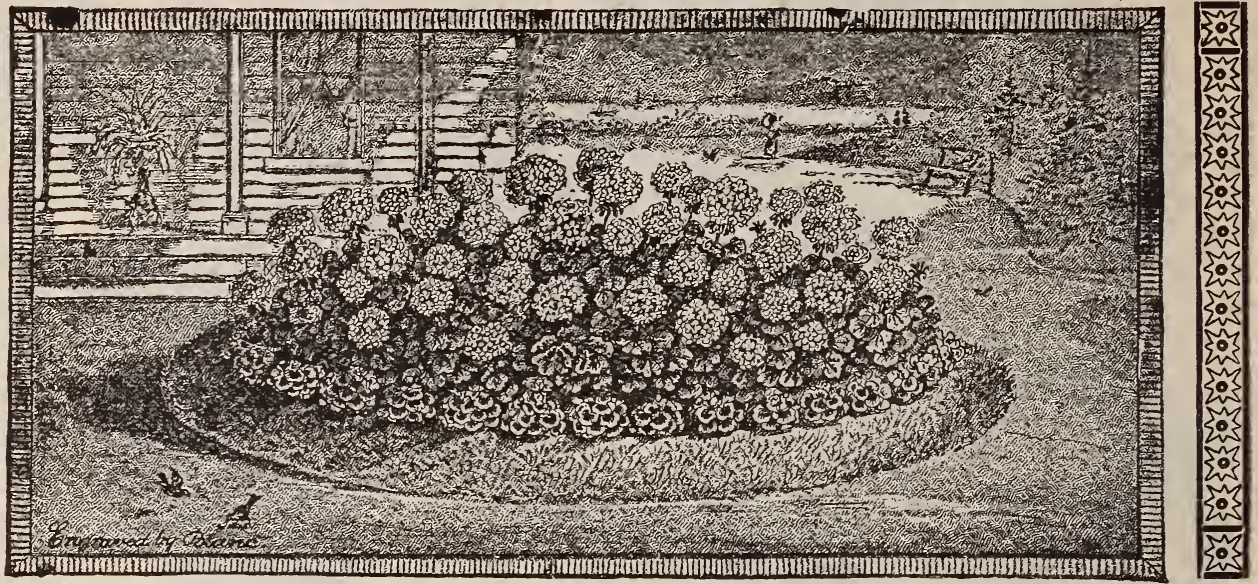

\section{THE BEAUTIFUL CEMETERY GERANIUM,} WHITE SWAN.

In the White Swan, we have the finest Double White Geranium ever introduced. The perfect double flowers are unsurpassed for cut flowers. They are borne in large trusses, and are spotless, snowy white, retaining pure whiteness even in the heat of Summer.

THE GREAT DOUBLE GERANIUM, BRUANT.

The giant among Geraniums. We consider this the best bedding Geranium of all varieties. Color of the flower is a bright vermilion-red of most pleasing shade. The flowers are absolutely perfect in shape, color and make-up; trusses exceptionally large, and borne in immense spherical balls, often measuring eight inches in diameter.

\section{FIREBRAND.}

Color-dazzling, flame-scarlet; fine, prominent truss, flowers large and of great substance; an excellent bedder and pot plant. For planting in masses we have none to equal it. Another thing in its favor, it takes fewer plants because of its sturdy, branching habit, to give effect.

\section{CONTRASTE.}

Among the most beautiful of new Double Geraniums is Contraste. The flowers and trusses are very large. Lower petals orange and carmine, upper petals clear orange, making a striking contrast of colors that is beautiful.

\section{OUEEN OF FAIRIES.}

Large, round florets of waxy appearance, color a rich flesh, mottled with pearly-white. An excellent pot variety, to which its habit is excellently suited. It is one of the prettiest Geraniums we have.

THE EXQUISITELY COLORED NEW GERANIUM, WILHELM PFITZER.

Beautiful, bright apricot color; quite distinct, and by far the best ever sent out of the color. Plant of perfect habit.

MINISTER OF CONSTANS.

Flowers very large and full, bright orange, shaded with salmon trusses stand well up above the foliage; it is also a fine pot variety, its distinct orange-salmon color always attracting attention.

\section{COMTESSE DE LA BAUME.}

One of the most beautiful rose-colored varieties, either for growing in pots or bedding out.

\section{DR. JACOBY.}

A magnificent Geranium, having enormous trusses of large, double flowers of clear nankeen-salmon.

HETHERA NTHE.

A magnificent rariety. Flowers bright red, trusses of enormous size, and borne high above the foliage.

\section{THE BEAUTIFUL ROSE-COLORED GERA-} NIUM, THEOCRITE.

Its colorings are simply without an equal-a soft, tender rose with violet shadings, entirely distinct from any other variety in coloring. Another characteristic of this new Geranium is its heavy, dense foliage, neatly zoned, and stands our hot sun admirably, and for bedding is without a rival.

CALIFORNIA, THE YELLOW GERANIUM.

Rich, golden-orange shade, of the most brilliant hue-we need not add another word to its color. The flowers are of the largest size, most perfectly shaped, in large trusses, opening freely at all seasons.

\section{IAA FAVORITE.}

In this new Geranium we believe we have the finest Double White Geranium in cultivation. It is a dwarf, compact growing variety, the foliage is a bright, healthy green, with a band of dark green encircling each leaf. The flowers are borne in large trusses of the purest snow-white, retain this pure whiteness even in the height of Summer, and for Winter blooming they are all that can be desired. See cut.

\section{CRIMSON VELVET.}

This is the darkest and richest Geranium grown. It is a very bright, dark, deep, rich, velvety-maroon, very dark and rich, and at the same time very bright. An excellent bedder and pot plant. Simply superb.

\section{MONTESOUIEU.}

One of the most exquisitely beautiful in color, which closely resembles that of the Grace Wilder Carnation. The floret is quite circular and more than semi-double. Truss of large size, nicely carried on good stems.

\section{MONS. M. MATHEWS.}

A bright rosz-crimson. The habit is dwarf, compact, and, with its great freedom of bloom, make it a most excellent bedder.

\section{MISS FRANCES F. WILLARD.}

It is of vigorous growth. the flower stalks arg very long and are carried well above the foliage; the color is a delicate blush, shaded with pearl-pink, a most charming piece of shading.

A splendid bedder bloming intermission and standing the sun well. The flowers are beautiful, deep, rich scarlet; fine, large florets of most perfect circular form. The best shaped flower of its class.

\section{A. DUPREE.}

Dark, rich velvety-crimson, shaded still darker. It is needless to say that this coloring is unusually handsome.

MRS. CHARLES PEASE.

Deep pink, white center. A magnificent sort.

-When ordering this collection, please say "Best Twenty Double Geraniums." This collection of Twenty Choice Double Geraniums for $\$ 1.00$ is the best and cheapest ever offered for 1 he price. 
* Che Monarch Collection *

\section{Choicest Single Geraniums for $\$ 1.00$}

Price per single plant 10c; any three for 25c; any eight for 50c. No further discount on this offer.

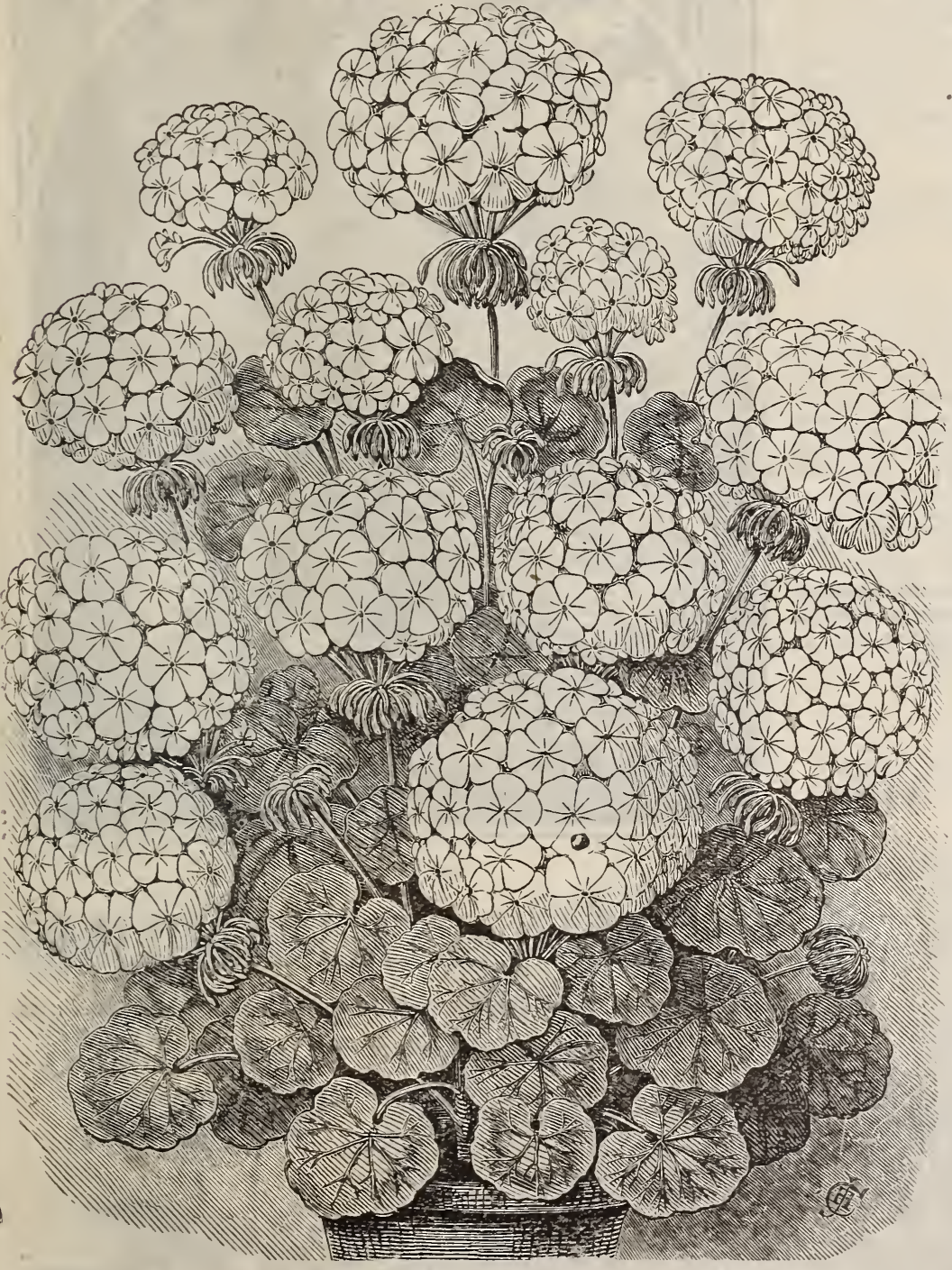

Monarch-This is a superb new $\nabla$ ariety, both as to growth and bloom, a nd probably the largest flowpring Geranium extant. It carries its immense trusses the foliage and is a continual mass of bloom during the entire summer. It well merits the proud name of Monarch.

Marguerite de Layres - A grand single white, plants a mass of white bloom, trusses of the grandest size florets extra large and of the purest white. The plant is robust. Grand for pots or bedding. It is by far the best single white. (See cut.)

P. A. Stewart-A new Geranium and a new color ver difficult to describe. It is a very light cerise pinkshaded salmon. A splendid bedder and exceedingly free bloomer.

Fran Louise Volth-Perhaps the grandest single pink Geranium out. Color a beautiful, clea r, brilliant cal mine rose, with a very large, pure whit e eye beautiful shape.

Giant-A fine sort: bright crimson scarlet shaded rer. micomer; im mense trusses, $51 / 2$ to 6 inches in diameter a monstrous flower and a giant grower.

The Beautiful Peach-Blos. som Geranium, Souvenir de Mirande-It is entirely distinct from any other $v a$ riety shown and is quite different frieties that hare marked varieties that have their appearance. It has round fiorets, upper petals crean-white with a distinct, rosy-pink border, low er ed with pure white.

Copernic-Trusses largest size; florets perfect; rose and dark carmine; center white.

Barbizet-Individual flowers very large, borne on long foot staiks. Color fresh, bright pink, maculated with white on upper petals. Single flowers.

The Bride-A beantiful Geranium and a splendid bedder color a soft blending of white and salmon.

Madonna-A magnificent bedding variety: trusses are of extraordinary size of almost pansy form ; the color is a sof light pink a beautiful and distinct shade. This variety has been universally admired by all who have seen it in flower a variety that will probably never be equalled.

Crimson Beauty-Dark crimson, shaded to dark srarlet; vel'y dark and beautiful ; the richest colored Geranium in existence.

Francois Arago-Single flowers finely formed; a free bloomer on strong foot-stalks; color, silvery-salmon, shaded peach Fine, glistening texture.

General Grant-One of the best bedding Geraniums in cultivation. Grows freely; blooms with greatest profusion; color a vivid scarlet.

Granville-A most beautiful, soft, delicate, pink color; very dwarf and free.

Mrs. E. G. Hill-Single. Florets $2 \frac{1}{2}$ inches. The center of each petal is a soft, light salmon, bordered with rosy-salmou and veined deep rose. Frequenúly throws six petals.

Mon. Poinsignon-Color bright aurora rose, shaded salmon, witt: a white eye; large trusses of splendid shaded flowers. 


\section{SIX BEAUTIFUL \\ ets et et et et et et
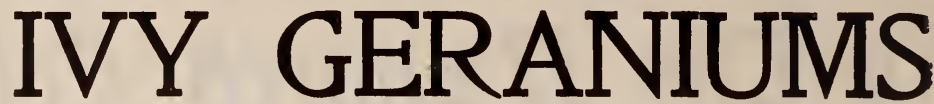

Price 10, cents each; any Three for 25 cents; the Set of Six for 50 cents.

New Double White Ivy Geraniums, "Joan of Arc." - This is one of the most beautiful plants that it has been our privilege to offer. The flowers are perfectly double, white as snow, and literally cover the plant when in full bloom. The foliage is extremely handsome, the dense, glossy green leaves making a most effective background for the great cluster of snowwhite flowers. Price, 10 cents each.

Souvenir Charles Turner-One of the handsomest Ivy Geraniums ever introduced. Florets two and one-half inches, in trusses six inches across. The color is a deep bright pink, approaching scarletin color ; the upper petals feathered maroon. Quite double Price, 10 cents each.

Camille Flammarion-A beautiful variety, and a general favorite with all lovers of the Ivy-leaf varieties. Flowers large, full, cupshaped, and a deep rose color. Price, 10 cents each.

Flourens-Flowers very large and double; petals large, salmon, heavily shaded rose.

New Hybrid Geranium, "Peter Crozy"-A cross between the Iry Geraniums and the Zonals. The foliage shows the blending of the two races, having the form of the Iry and the substance and size of the Zonals. The flowers are brilliant scarlet, borne in the greatest profusion, the trusses measuring six inches across and the individal florety two inches. are semi-double and last a long time.

Galilee-Rich, deep pink, large flowers of good substance, and not only flowers in Summer, but will make a beautiful plant for the window in Winter. Price, 10 cents each.

These are splendid plants for vases and hanging baskets. They certainly are a beautiful sight, as they trail over and down the sides of the vases or baskets, and they are always in bloom.

\section{BEAUTIFUL}

\section{GOLDEN-BRONZE}

\section{GERANIUMS..}

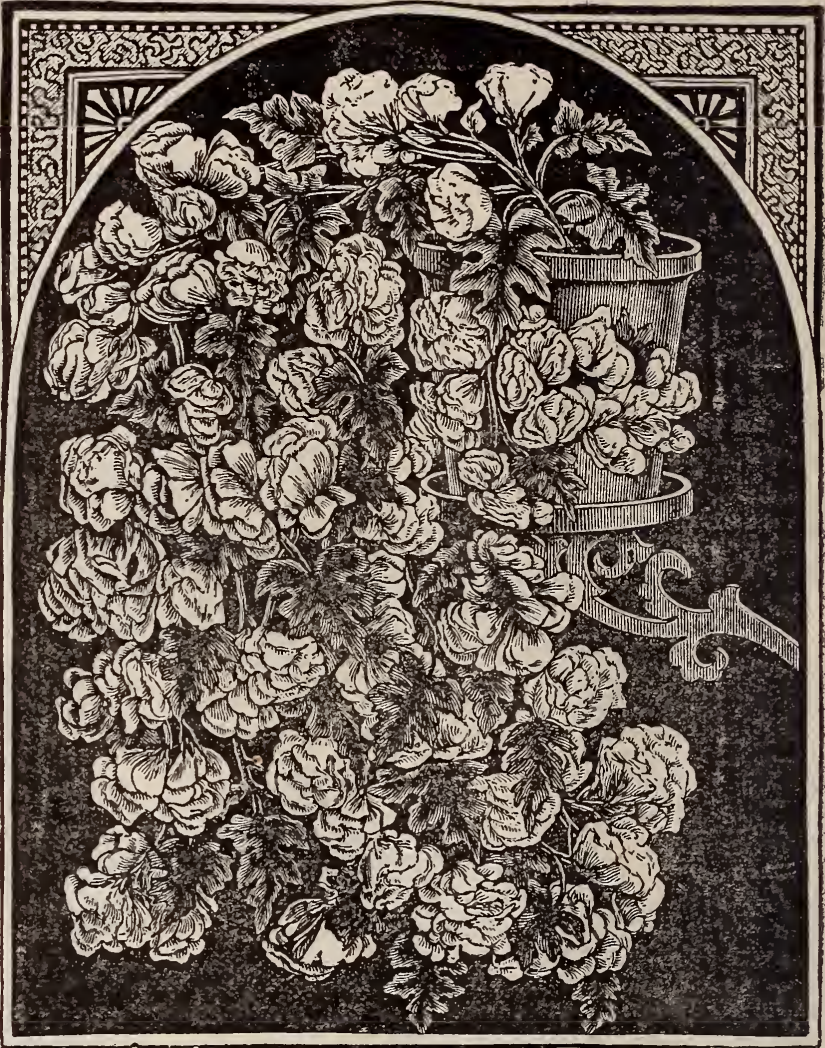

These Geraniums make beautiful pot plants. They are also of great value in planting for ornamental bedding. We have a fine assort ment at 10 cents each.

WE w!ll send three distinct Bronze Gera-
niums for 25 cents.

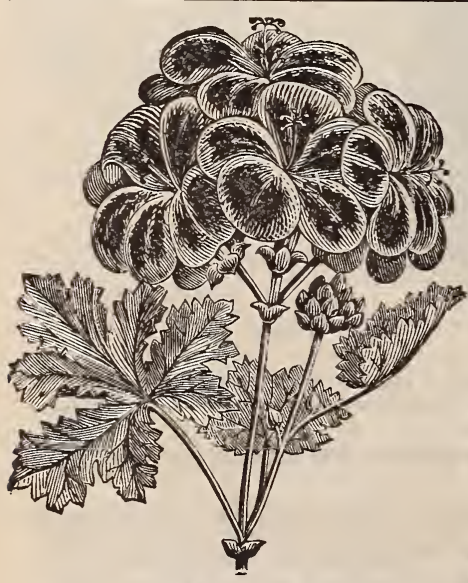

MRS. TAYLOR.

\section{SWEET - SCENTED GERANIUIMS}

Price, 10 cents each, except where noted; any 3 for 25 cents Balm-Large leaves, with very strong fragrance.

with delightful lemon scent, one of the most pleasing varieties.

Mrs. Taylor-Dark green foliage of a peculiar fragrance. Flowers are scarlet, shaped like a Pelar gonium and borne in great profusion. (See cut.)

Rose-Too well known to nee ${ }^{d}$ description. They are indispensable in the formation of bouquets. We have two varieties; one is broad leaved and the other with fine cut leaves. Price, 8 cents each.

Apple-Scented Geranium - One of the best scented Geraniums. Velvety texture to the leaf and very fragrant. Price, 10 cents; three for 20 cents.

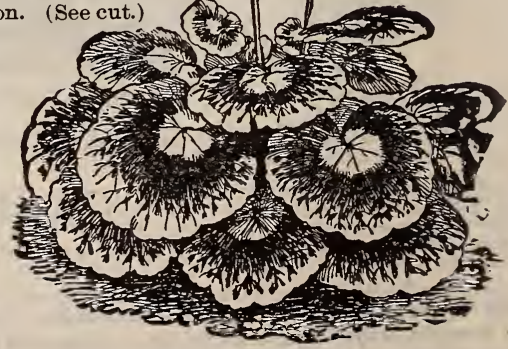

BRONZE GERANTUM. 


\section{- Dovelties in Geraniums.}

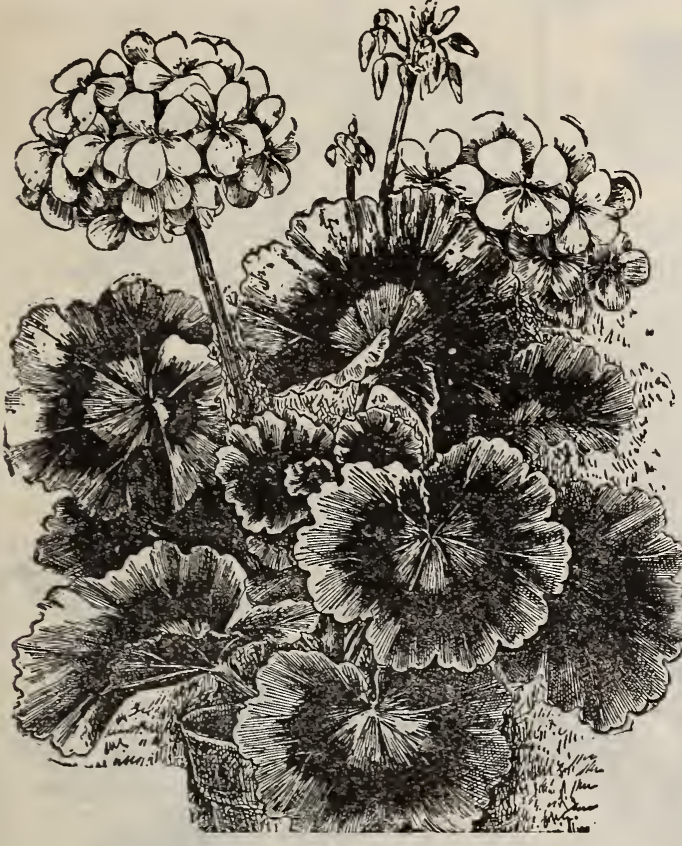

GFRANIUM SUNSET

NEW DOUBLE ROSEBUD GERANIUM

(F1orets like perfect Rosebuds.)

The habit of growth is dwarf and compact, making this variety one of the most desirable for pot culture. The novelty and merit, however, is principally in the flower, the perfect trusses of miniature rosebud florets, which are wonderfully attractive and pleasing. The color is bright scarlet, flamed with purple shadings, and the substance most lasting. A buttonhole bouquet of this variety will last longer than any other we know of, and then it is entirely unique. Certainly no Geranium in cultivation today is as distinct, and we are certain this remarkable novelty will make a sensation. Price, $10 \mathrm{c}$ each.

The Lady

Washington or

\section{PANSY}

GERANIUM.

We take pleasure in being able to offer plants of this very useful Pelargonium. There is nothing that gives better returns for a little care when grown in the window garden than this plant; it will be literally plant; it will be literally flowers are bright cherry red. with white at the base of each petal; the two upper petals are dark crimson-maroon The flowers are of immense size and very freely produced. It is this combina. tion ${ }^{\prime}$ lt is this which obtained for it the which obtained for it the title of "Pansy Geraniv
isee cut. Price, $15 \mathrm{c}$ each.
APPLE SCENTED GERANIUM

Has the fragrance of ripe apples. Well known favorite. Our plants of these are very fine. Price, $10 \mathrm{c} \mathrm{each}$.

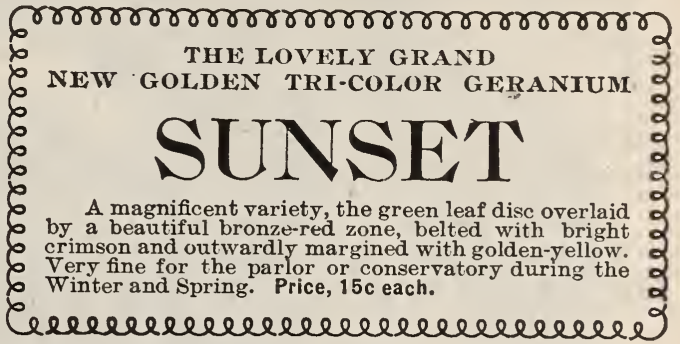

Three Splendid Silver Geraniums. For Out-door Planting or Pots.

Mountain of Snow-A vigorous grower, abundant bloomer, and for ribbon lines of massing is one of the best. Center of leaf bright green; outer margin broadly marked silvery-white. One of the whitest leaved sorts, flowers bright scarlet. Largely used for edgings around beds of flowering Geraniums, and also beds of Coleus. Price, 1 cc each.

Madame Salleroi-Fine variety of Silver Geranium; fine for massing or bordering; a thrifty, healthy grower Leaves very small, a peculiar clear green, edged pure white. Price, $10 \mathrm{c}$ each.

Happy Thought-A tri-color Geranium with very dark-green foliage, having a light, creamy, almost white center, with a dark zone. Flowers bright scarlet. Price, 10c.

The Three Silver Geraniums for 25 Cents.

THE QUEEN AMONG GERANIUMS, "SPRINGFIELD BEAU'TY."

This lorely variety is simply exquisite, being a beautiful orange-salmon center and outer petals veined deep salmon and shaded white towards the edge. It is a very strong grower and is an excellent bedder. A sterling novelty.

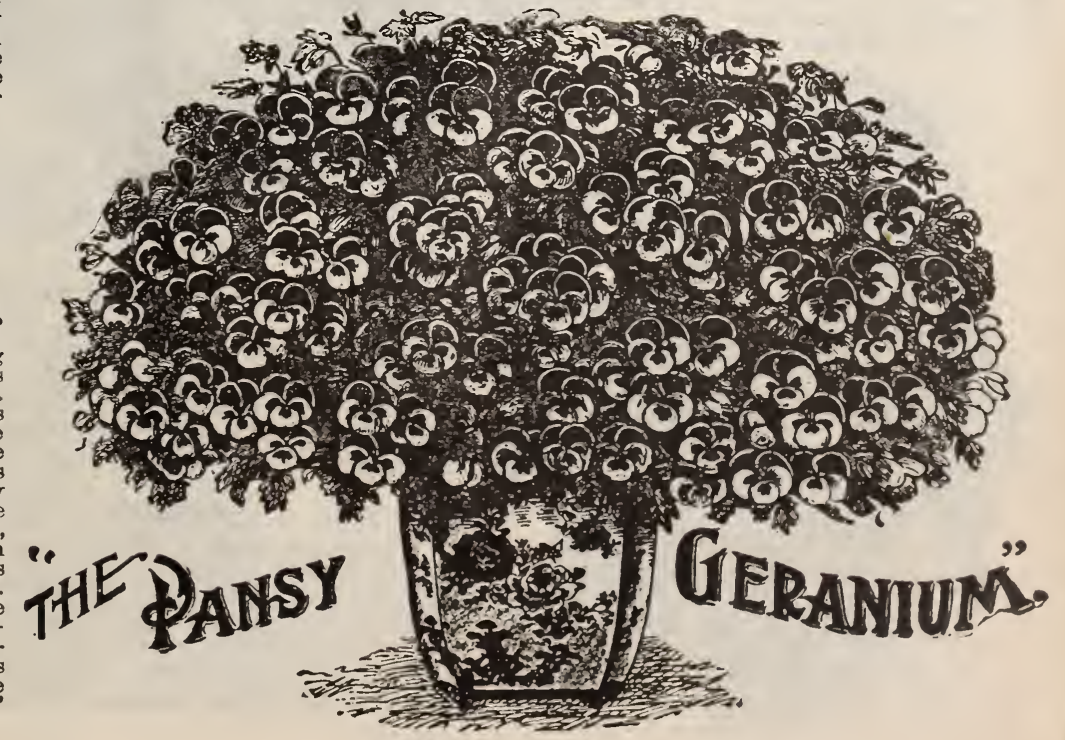




\section{* CHOICEST HLOWERING BEGONIAS.}

OUR GENEROUS OFFER.

You may select any ten priced

at 10 and 8 cents each for only 75 cents, or we will send 20 choice sorts strictly our selec= tion, by express for only $\$ 1.00$.

THE GRAND NEW GIANT BEGONIA

SEMPER = FLORENS GI GA N T E A ROSEA.

A superb variety, strong, upright, grows large flowers of clear cardinal red, the bud only exceeded in beauty by the open flower, which is borne on a strong, thick stem. The leaves are smooth and glossy and attached closely to the main stem; both leaf and stem are quite upright growing, and form ing a shrubby round plant. Price. 15c each; two for 25c. (See cut)

\section{BEGONIA,} FEASTII.

A low, spreading Begonia, with perfectly circular leaves, red beneath and dark glossy green above, and of heavy texture. The finest pot Begonia we have for house culture. Don't fail to try it. Price, 15c each.
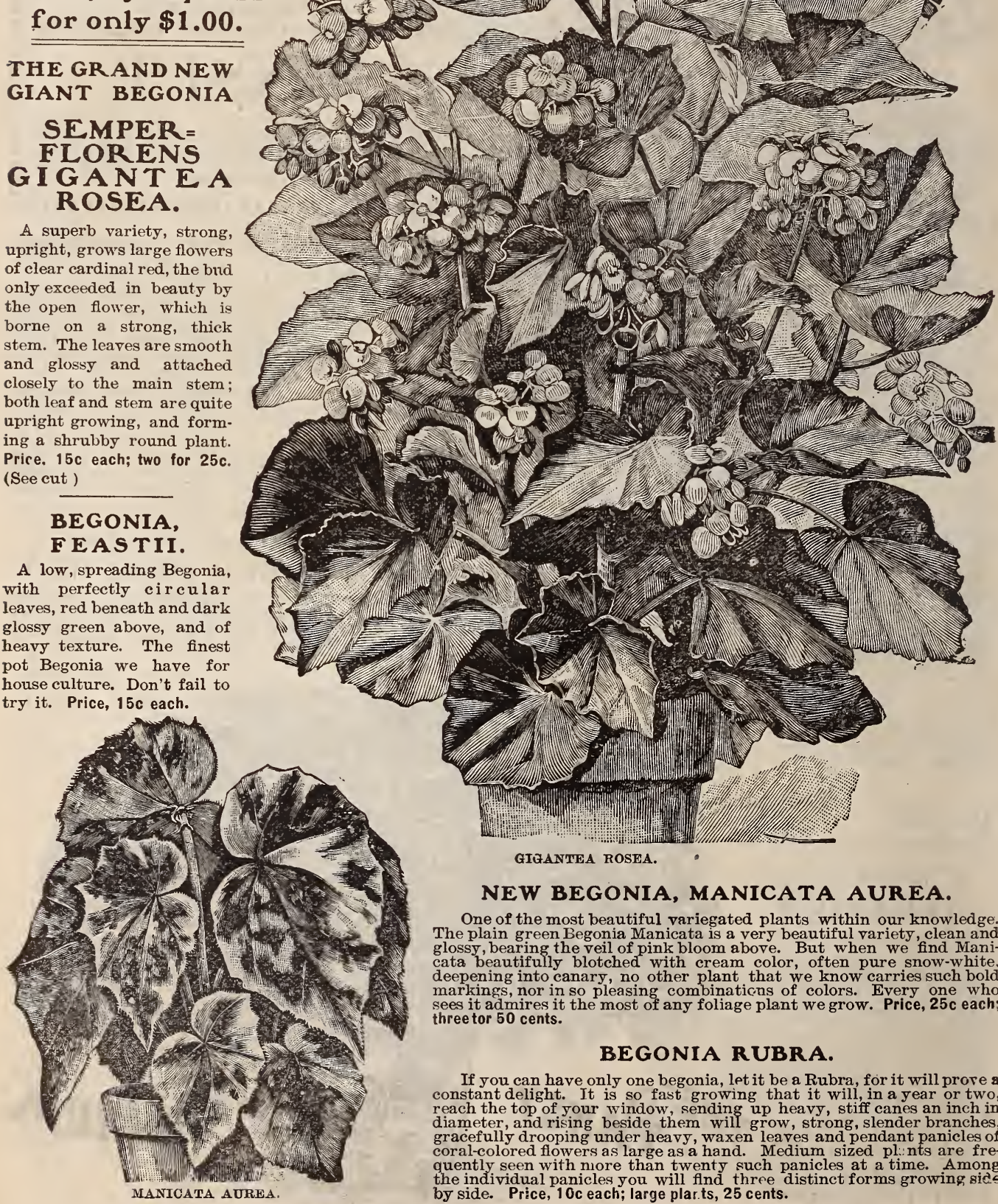

GIGANTEA ROSEA.

NEW BEGONIA, MANICATA AUREA.

One of the most beautiful variegated plants within our knowledge. The plain green Begonia Manicata is a very beautiful variety, clean and glossy, bearing the veil of pink bloom above. But when we find Maniglossy, bearing the veil of pink bloom above. But when we hnd-whitecata beautifuly blotched with cream color, often pure snow-white. deepening into canary, no other plant that we know carries such bold sees it admires it the most of any foliage plant we grow. Price, $25 \mathrm{c}$ each; three tor 50 cents.

\section{BEGONIA RUBRA.}

If you can have only one begonia, let it be a Rubra, for it will prore a constant delight. It is so fast growing that it will, in a year or two, reach the top of your window, sending up heavy, stiff canes an inch in diameter, and rising beside them will grow, strong, slender branches, gracefully drooping under heavy, waxen leaves and pendant panicles of coral-colored flowers as large as a hand. Medium sized pl: nts are frecoral-colored fowers as large as a hand. Medium sized plints are frequently seen with more than twenty such panicles at a time. Among by side. Price, 10 c each; large plar.ts, 25 cents. 


\section{FLOWERING BEGONIAS Any Ten 7 Fon $75 \mathrm{c}$}

ARGENTEA GUTTATA. It has purple-bronze (New Begonia) leaves, oblong in markings, and is in every way a most beautiful Begonia. It produces white flowers in bunches on ends of growth stems. It will be splendid for house culture. Price, 10 cents each. See cut.

BERTHA De CHATEAUROCHER. Next to this is the finest flowering Begonia we have. It blooms the rear round, makes a handsome window plant with its beautiful foliage and bright currantred flowers. Price, 10 cents each.

PRESIDENT CARNOT. A remarkably strong (New Begonia) liagevery large; flowers beautiful coral red, in large pendant panicles similar to Rubra, but very much larger. A great acquisition; one that is sure to succeed under all circumstances. Price, 10 cents each.

SANDERSONII. One of the best flowering BeSonias. The flowers are a scar(Coral Begonia) let shade of crimson borne in profusion for months at a time. Price, 10c each DEWDROP. Is always in bloom; will stand the one of the finest plants ever introduced. Flowering Begonias are the most satisfactory plants for house decoration. In the new Begonia Dewdrop we have the best flowering Begonia ever obtained. Price, 10 cents each.

M. D. LESSEPS. It is beautifully spotted with (New Begonia) silver. A very strong, freeceed with any ordinary care, growing rapidly and sending out quantities of lovely pink and white flowers. A magnificent Begonia. Price, $10 \mathrm{c}$ each. MARGUERITE. Leaves a bronzy green, somegrowing a more bushy form, and easier to handle

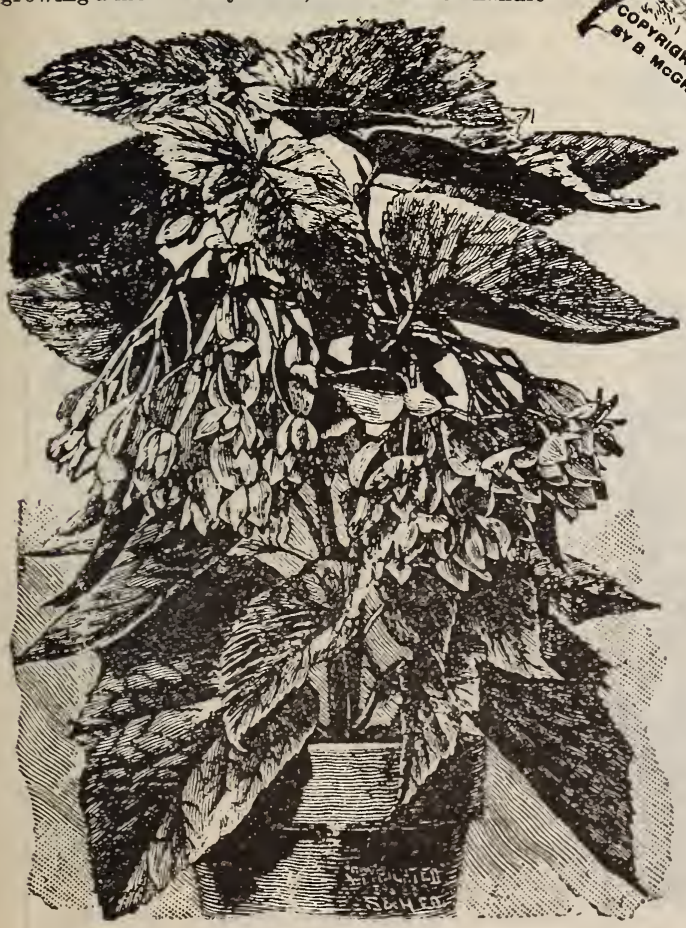

MONS, DE LESSEPS.

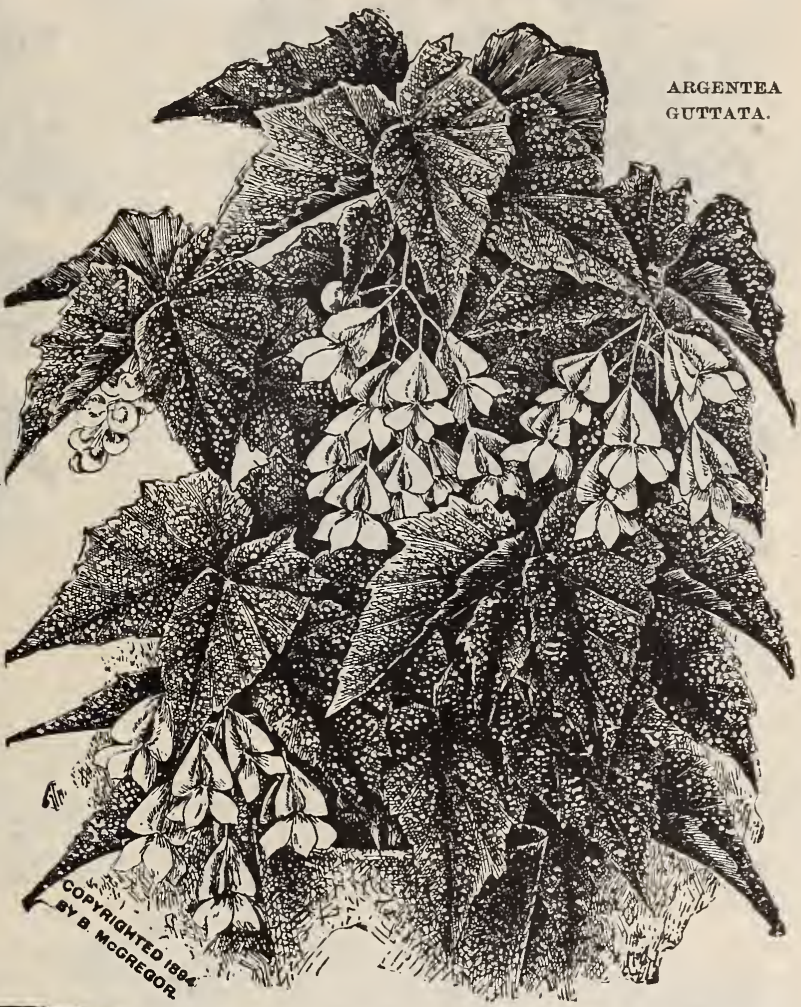

when grown for market. Large trusses of light, rose-colored flowers freely produced. Price, 10 cents each.

HYBRIDA MULTIFLORA. This beautiful plant makes graceful branches and pendulous flowers specimens, with it Very floriferous. Price, 8 cents each.

M'BETHII. Of the Weltoniensis type, with very deeply in dented leaves, which are fineand small. Shrubby round and very constant the year Put it among rour ferns White flowers, waxy texture, carried in panicles. Price, 8 cents each.

FOLIOSA. Foliage small; contrasts well with its whit

ANGEL'S bloom; elegant. Price, 8 cents each.

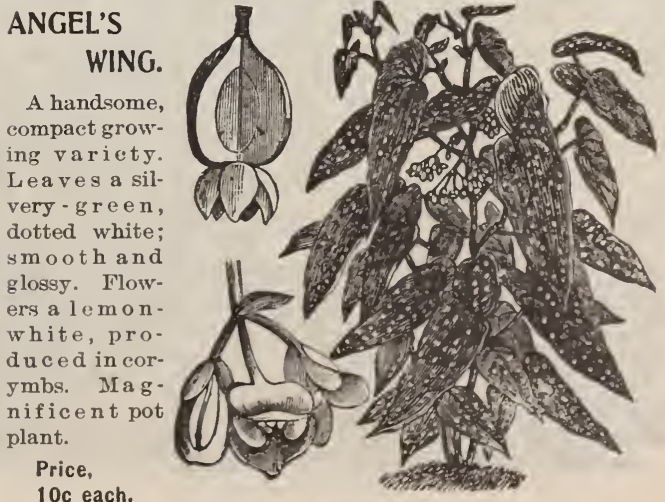

10c each.

ANGEL'S WING. 


\section{FLOWERING BEGONIAS-Continued.}

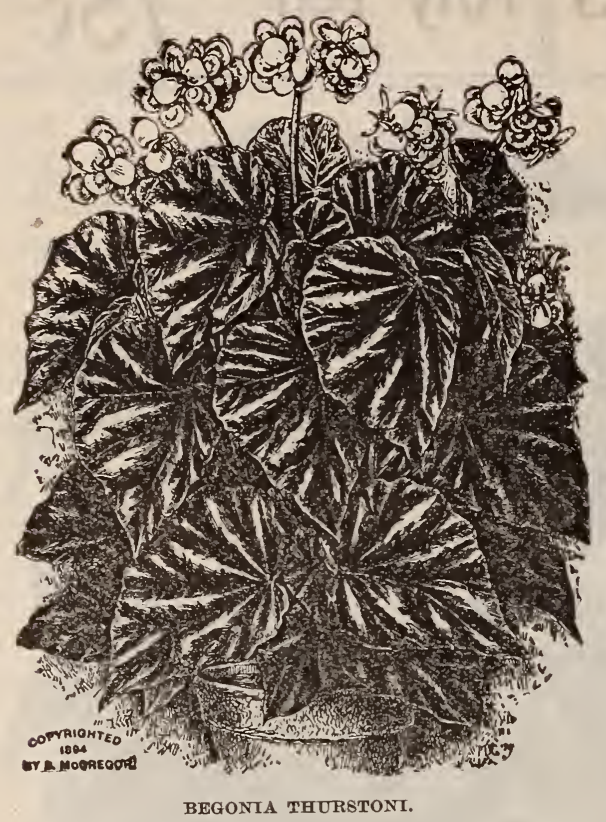

NEW BEGONIA THURSTONI.

This Begonia is a cross between B. Metallica and B. Sanguinea, having the bright-red foliage and veinings underneath the leaves, and bright metallic green, shading to red in the younger growth on top, with the deep veinings of the Metallica and smooth glossy leaves and red stems of the Sanguinea; the flowers are a beautifuldeep pink in bud, but when
expanded become a beautiful shell-pink. Price, 10 cents each.

\section{NEW BEGONIA, VERNON.}

This elegant new variety is of unusual merit as a bedding sort, flowering fully as freely when planted out as when grown as a pot plant. It begins flowering when first planted arown as a pot plant. It beginues throughout the whole season until stopped by frost. Foliage rich glossy-green, of ten shaded deep bronze. Flowers at first opening are a deep red, changing to a beauti. Flowers at first opening are a deep red. It thrives everywhere and is destined to become one of the most popular of bedding plants. Price, 10 cents each.

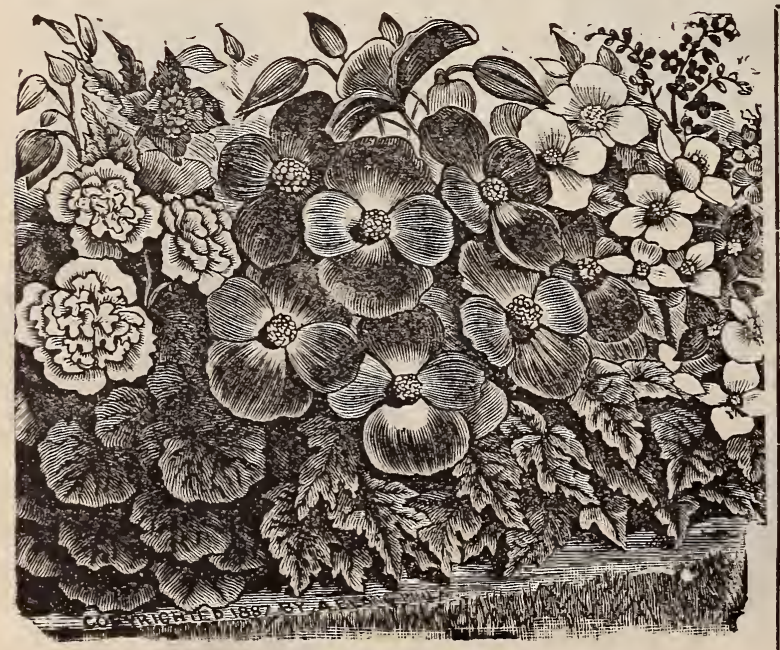

TUBEROUS BEGONIAS.

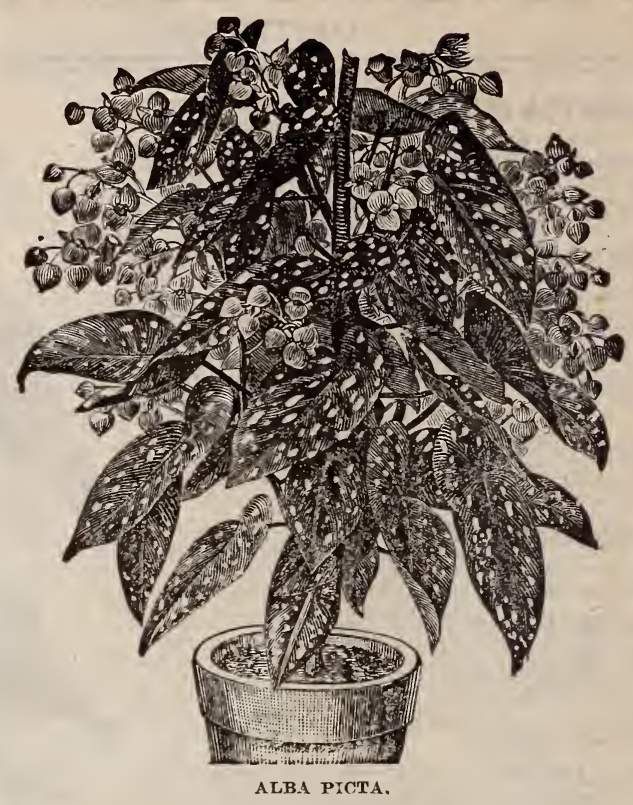

\section{ALBA PICTA.}

A perfectly distinct variety; shrubby in habit and of very compact growth, having slender, pointed leaves and short stems. The leaves are glossy green. thickly spotted with silver-white; folliage small and elegant. Branches upright and gracefully curving. Price, 10 cents each.

\section{FUCHSOIDES COCCINEA.}

Elegant free-blooming variety; resembles Hybrida Multiflora in growth; flowers are bright scarlet. Price, 8 cents each.

\section{ALBA PERFECTA GRANDIFLORA.}

(White Rubra.) We doubt if there is a white flowered variety that equals it. The foliage resembles Rubra in shape, but is a lighter green, while the flower panicles are much handsomer. It is a pure white flowering Begonia of much merit. Try it. Price, 10 cents each.

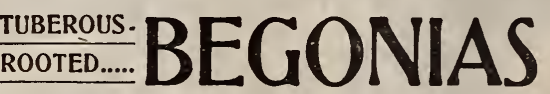

These are among the wery handsomest of our Summer blooming plants, flowering throughout the season, and as fine and varied in their color as the Geranium famiiy. They are splendid bedders, delighting in a light soil of wood earth, very old cow in partial shade, and you will bedelighted with the results In the South, or where they cannot be planted in the shade of a house, a covering of bur. lap or canvas, some six or eight feet above them merely to throw off the sun's rays, will allow them to come to absolute perfection, but they must have plenty of light and air. Do not allow them to becomedry, and during hot weather they will take two waterings a day, when through flowering they can be dried off, shaken free of earth, and wrapped in cotton untilFebruary or March, when they may be started agair.

SINGLE-White, Yellow, Crimson, Rose, Scarlet. Price, $15 \mathrm{c}$ each, four for $40 \mathrm{c}$.

DOUBLE-In same colors, 20c each; four for $60 \mathrm{c}$. 


\section{Showy Bedding Salvias $\frac{\text { Brillart Flowers }}{\text { and Foliage }}$}

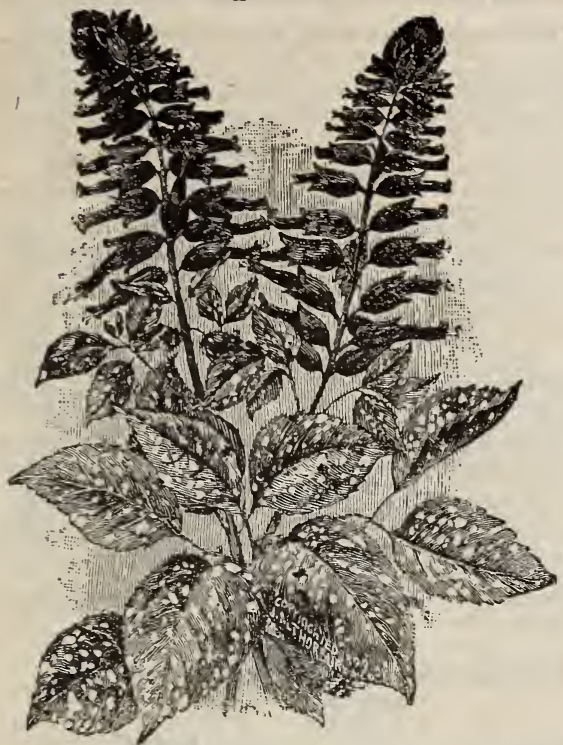

SALVIA SPLENDENS, SILVERSPOT.

We will send the set of four distinct Salvias for on1y 25 cents.

\section{SALVIA} SPLENDENS.

One of the finest of all blooming plants, being completely covered in of dazzling scarlet flowing in bloom until cut down by frost. Price, $8 \mathrm{c}$ each; four for $25 \mathrm{c}$.

\section{ALBA.}

A white variety of Splendens, identical in every respect, except white. Price, $8 \mathrm{c}$ each.

\section{SPLENDENS} VARIEGATA.

White and red flowers, very evenly striped. Price, $8 \mathrm{c}$ each.

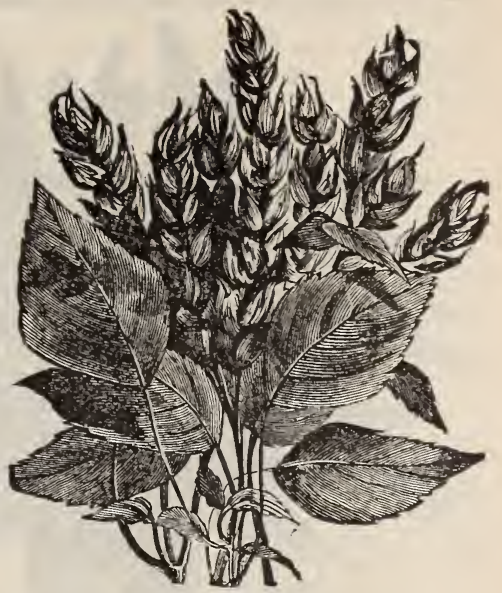

SALVIA SPLENDENS.

\section{NEW SALYIA SPLENDENS}

\section{"SILVERSPOT.",}

The distinctive feature of this splendid novelty is itis strikingly hand some spotted foliage The leares are rich soft dark green, with light sulphur or cream-colored spots of various sizes liberally sprinkled over them. The intense, bright scarlet flowers are very large; the plants are of neat, compact habit. This will make a desirable bedding plant, rivaling the most gorgeous Coleus, its bright spotted leaves and brilliant scarlet flowers making it a most effecti
der. Price, $8 \mathrm{c}$ each; 4 for $25 \mathrm{c}$; 10 for $50 \mathrm{c} ; 25$ for $\$ 1.00$.

\section{Che tJonderful Giant Blooming Бydrangeas. . .}

\section{The Monstrous \\ Flowered New}

\section{Hydrangea, Monstrosa.}

This is a new plant of the greatest merit. Color of bloom intense rose shaded white borne in clusters over eighteen inches in diameter. The flowers of Monstrosa are twice the size of any other Hydrangea, quite small plants bearing blooms of the most enormous size, often sta ying on the bush for a month. Price, 10c each; 3 for 25c.

\section{New Red-Branched}

Hydrangea, Ramus Pictus

It is very handsome, the oliage being dark green, with black stems, making it very distinct. Flowers rosy - carmine, hanging to blue, the dark green foliage and purple-black stems being in contrast with rosy列, $15 \mathrm{c}$ each.

\section{The Pure White}

Hydrangea, Thomas Hogg

A pure white variety with trusses measuring fifteen inches in diameter. The plants, when full grown, attain a height and width of six feet. Perfectly hardy and is one of the finest plants for cemeteries. Price, 10c.

SPECIAL OFEER.-We wiil send one each of these three grand Hydrangeas for only 30 cents.

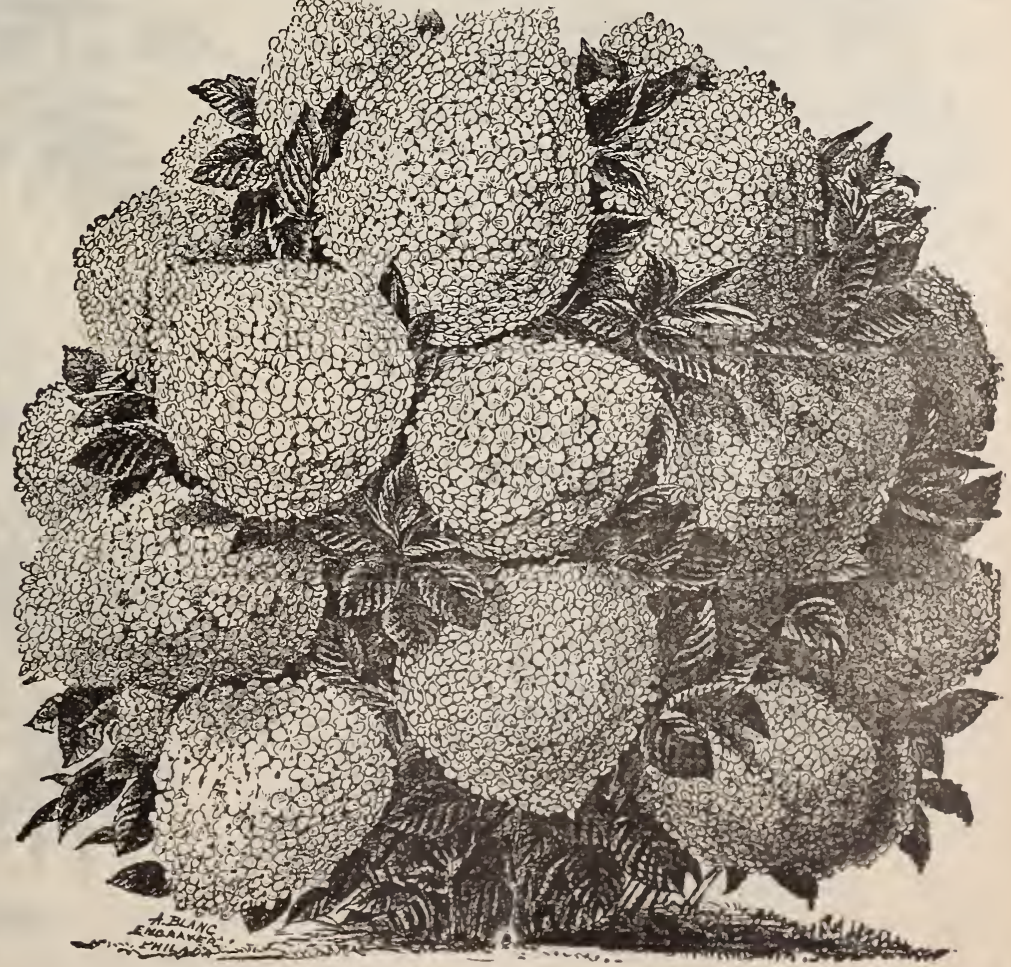

THE GIANT HYDRANGEA MONSTROSA. 
THESE BEAUTIFUL PLANTS are now generally cultivated. Their great diversity and gracefulness of foliage make them much valued as plants for vases, baskets or rock work, or as specimen plants for parlor or conservatory. Keep them out of the direct sunlight, and water carefully, that thedelicateroots lying near the surface may never become dry.

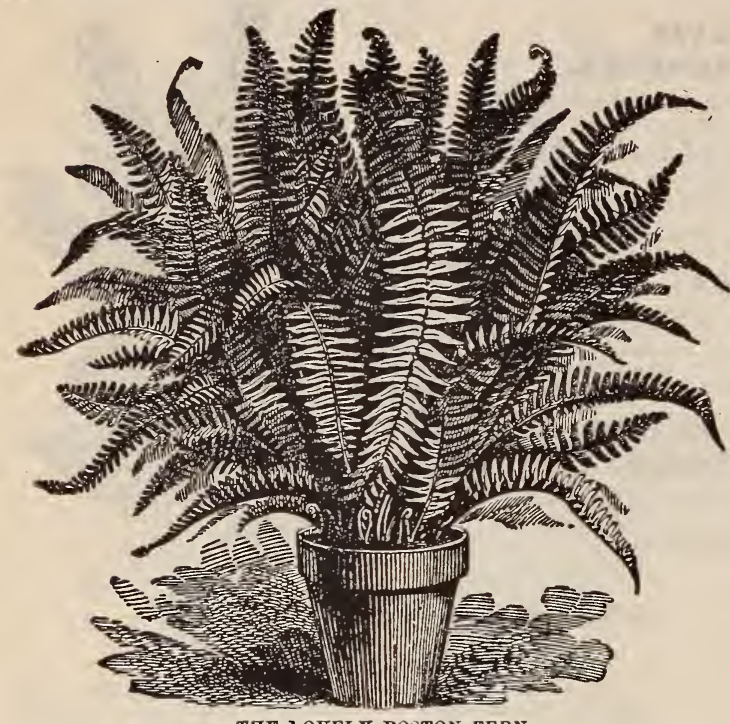

THE LOVELY BOSTON FERN.

THE HOLLY FERN.

So called on account of the similarity of its foliage to that of holly-bright, glossy green. It has also been called The Leather Fern, on account of its easy culture. It is a tip-top house plant, easily grown. Price, 15c each.

\section{OUR SPECIAL OFFER IN CHOICE * * FERNS AND PALMS. * * *}

For the benefit of those of our patrons who admire Palms and Ferns we make the following extremely liberal offer:

FOR ONLY $\$ 1.00$ we will send either by mail or express (but nicer and larger plants by express) four dintinct Ferns all large, strong plants that will make beautiful specimens this summer, and three handsome Palms all distinct and all with character leaves out of four inch pots.

The varieties must be strictly our own selection but will consist of the very best varieties that grow.

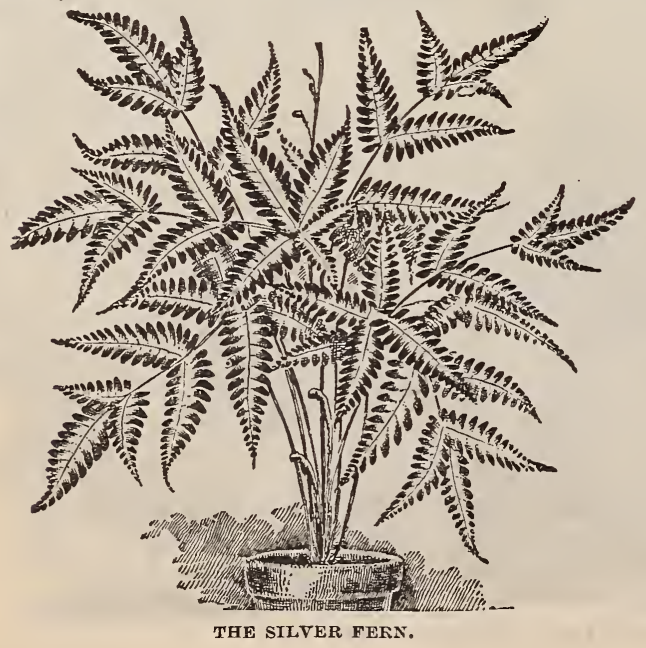

The Boston Drooping Fern-(Nephrolepsis Bostoniensis). Of which much has been heard during the past year; of the same form as the Sword Fern, Nephrolepsis Exaltata, but has larger and broader fronds; a more drooping habit. In well grown specimens the fronds attain a height of six to seven feet. Fine for hanging pots and baskets. Price, $10 \mathrm{c}$ each; large plants, $20 \mathrm{c}$.

Adiantum Cuneatum-(Maiden Hair Fern). A very beautiful and graceful Fern, its delicate fronds being much used for cut flower work. 'Price, $15 \mathrm{c} \mathrm{each.}$

Sword Fern-(Nephrolepsis Exaltata). A really graceful Fern, multiplying very fast in throwing out vines, on which grow separate plants again. Price, $15 \mathrm{c}$.

Nephrolepsis Cordata Com vacta-A new Sword

Fern. A decided improvement on the old variety; is moredwarf and compact and will produce three times the number of fronds. Introduced last year for the first time. Price, $15 \mathrm{c}$ each.

Pteris Cretica Alba Lineata-A very handsome Fern, nicely variegated; grows very rapidly into handsome plants. Price, 15c.

Pteris Tremula-Shaking Fern. One of the finest Ferns for house decoration, growing very rapidly, and throwing up large, handsome fronds. It makes magnifcent specimens. Easily grown and popular. Price, $15 \mathrm{c}$. Pteris Argyrea-(Silver Fern). A very showy Fern with variegated foliage; fronds large, light green with a broad band of silver-white down the center of each. Very distinct. Price, 2 jc each.

Pteris Serrulata-A useful basket variety of graceful habit. $10 \mathrm{c}$.

\section{You may select any five of the above choice} Ferns for 50 cents.

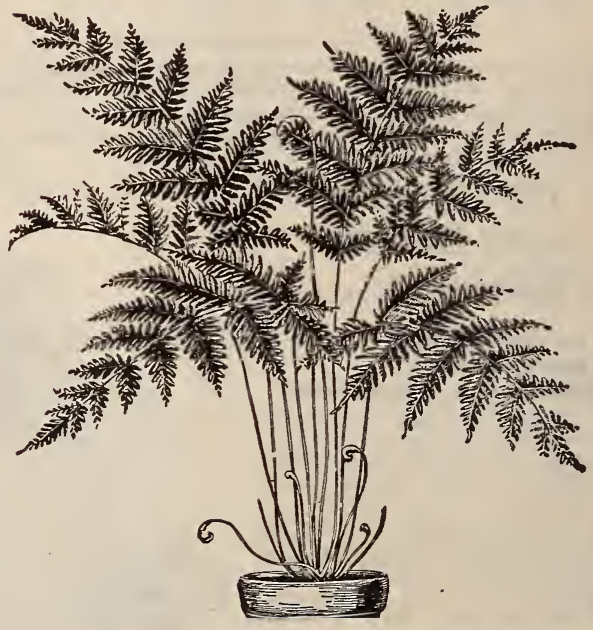

THE SUAKING FERN.

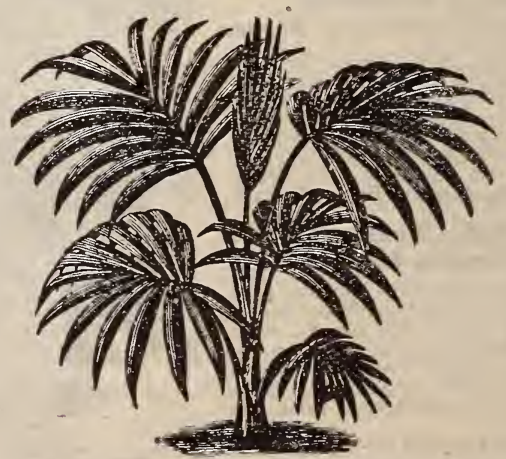

This collection of Ferns and Palms is net and subject to no further discount. 


\section{... Fandsome Decorative Palms...}

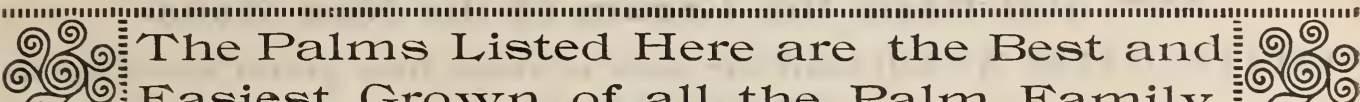
(ㅇ) Easiest Grown of all the Palm Family. (0)

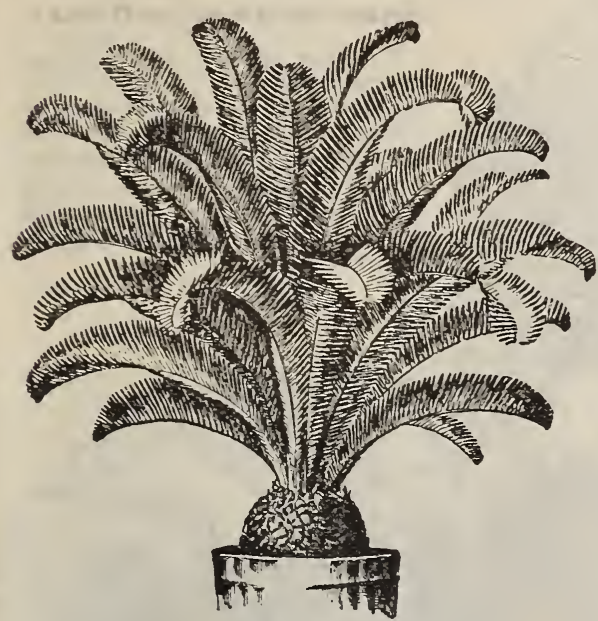

CYCAS REVOLUTA.

\section{KENTIA FOSTERIANA}

This is one of the finest pot plants imaginable and the easiest to grow of any of the Palm family. Being almost hardy, it is not injured by slight changes in temperature, and its stiff, glossy leaves enable it to stand the dry. hot air of the living room without injury. The leaves are a deep, glossy-green, fan-shaped, split deeply into segments. This is, without exception, the most hard $y$ of its class. Very graceful for table decoration. Scarcely equaled. Price, nice, strong pliznts, with character leaves, out of three. inch pots, $25 \mathrm{c}$ each: strong, I andsome plants, from four-inch pots, $50 \mathrm{c}$ each; nice specimens from five and six inch-pots $\$ 1.50$ each. This last size must be sent by express.

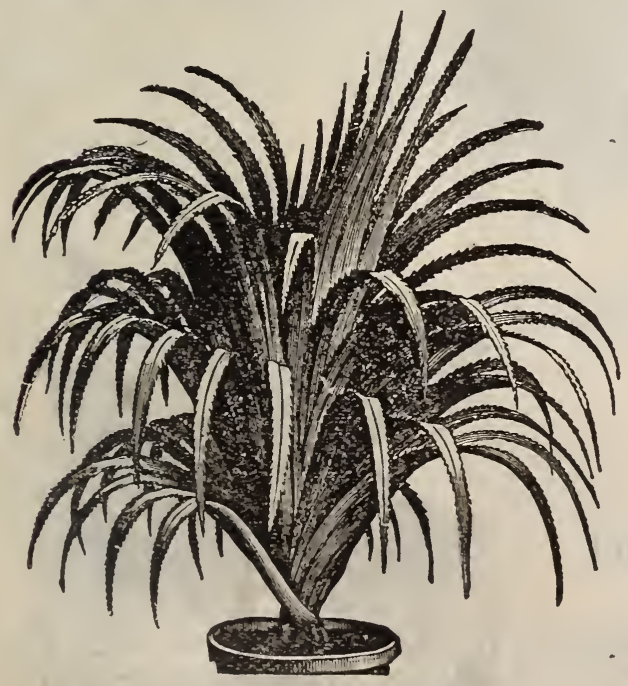

\section{CYGAS REVOLUTA SAGO PALM.}

The Crcas makes a magnificent specimen plant, and is one of the most valuable plants grown for the decoration of the lawn or house. cold to which decoratire plants are frequently exposed. Price, fine, shapely plants out of six-inch pots $\$ 1.00$ each.; extra fine large specimens out of seven-inch pots, $\$ 1.50$ each, can only $b$; sent by express.

\section{LANTANIA BORBONICA.}

The well-known Fan Paln. This is one of the most exquisitely graceful among Palms. Its wide-spreading, gracefully arching leaves are elegant and effective for apartment decuration. It is considered the handsomest and most raluable of all the Palms. Nice plants showing character leaves, from three-inch pots, $25 \mathrm{c} \mathrm{each}$; strong, handsome six-inch pots $\$ 1.00$ and $\$ 1.50$ each. These last two sizes must be sent by express.

\section{PANDANUS UTILIS} SCREW PINE.

A grand decorative plant. Its glossy dark-green foliage, grace, fully arranged renders it particularly attractive; fine for centers of vases or baskets, or for growing as single specimens. Price, 25c each: larger, by express, $50 \mathrm{c}$ each.

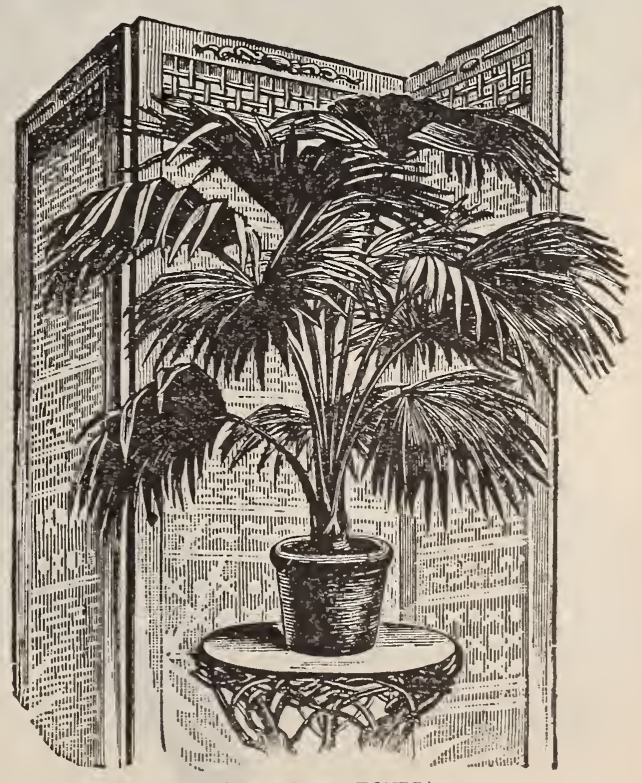

LATANTA BARBONICA.

\section{KENTIA BELMOREANA}

The Kentias are among the best of the Palm species for general cultivation being almost impregnable against disease. This variety is one of the best in its class-graceful habit, bright-green foliage, gracefully disposed. As a decorative plant for the window, dinner table or conservatory, it scarcely has an equal. Price, nice young plants. with chara ter leaves, 25c each: elegant plants out of four-inch pots. $50 \mathrm{c}$ each: beautiful specimens from six-inch pots $\$ 1.50$ each. The last size must be sent by express.

NOTE-We strongly advise having all Palms sent by express. Our large size plants cannot be sent by mail. 


\section{TEN MAGNTFIOENT}

\section{NEW EVER-BLOOMING GANNAS}

AMERICA'S MOST POPULAR BEDDING PLANT.

This Superb Collection Includes only the very Choicest Sorts and the Widest Range of Color.

A SPLENDID OFFER-We will send five distinct, new, large, flowering Cannas from this set for only 50 cents, or the entire set of ten choicest sorts for only $\$ 1.00$. No discount on this offer.

The Royal New Canna, QUEEN CHARLOTTE

Bright orange-scarlet,deeply edged bright canary-yellow. The Howers are rery large, with broad, wellrounded petals, borne in immense heads, well above the foliage. The leaves are large, musa-like, deep habit. Price, $15 \mathrm{c}$ each.

The New White Canna, "ALSACE"

A vigorous grower, green foliage, four feet high; produces from 12 to 18 trusses of flowers in a season; an early and continuous bloomer. The trusses upon opening, are of a delicate sulphur-yellow, changing very soon, however, to a creamy white, without spots. Price, 10c each.

The Gilt-Edged Canna, MADAME CROZY

Undoubtedly the grandest of all varieties. The color is a brilliant vermilion-scarlet, bordered with veep golden-yellow: flowers are deep golden-yellow; fowers are profusion that they crown the plant with a blaze of growing color. Price, $10 \mathrm{c}$ each.

The Lovely Orchid Flowering Canna,

\section{ITAYIA}

One of the wonders of recent introduction, with large, musa-like foliage. The flower spikes produce a number of extraordinarily large flowers of a beautiful scarlet color edged with sellow; a plant that should be in every collection. Price, 10 each.

The Handsome Lily Flowered Canna,

A USTRIA

A companion to Canna, Italia ; the same wonderful qualities of growth and flowers, with the exception that its wonderful large blooms are of a beautiful canary yellow. Prtce, 10c each.

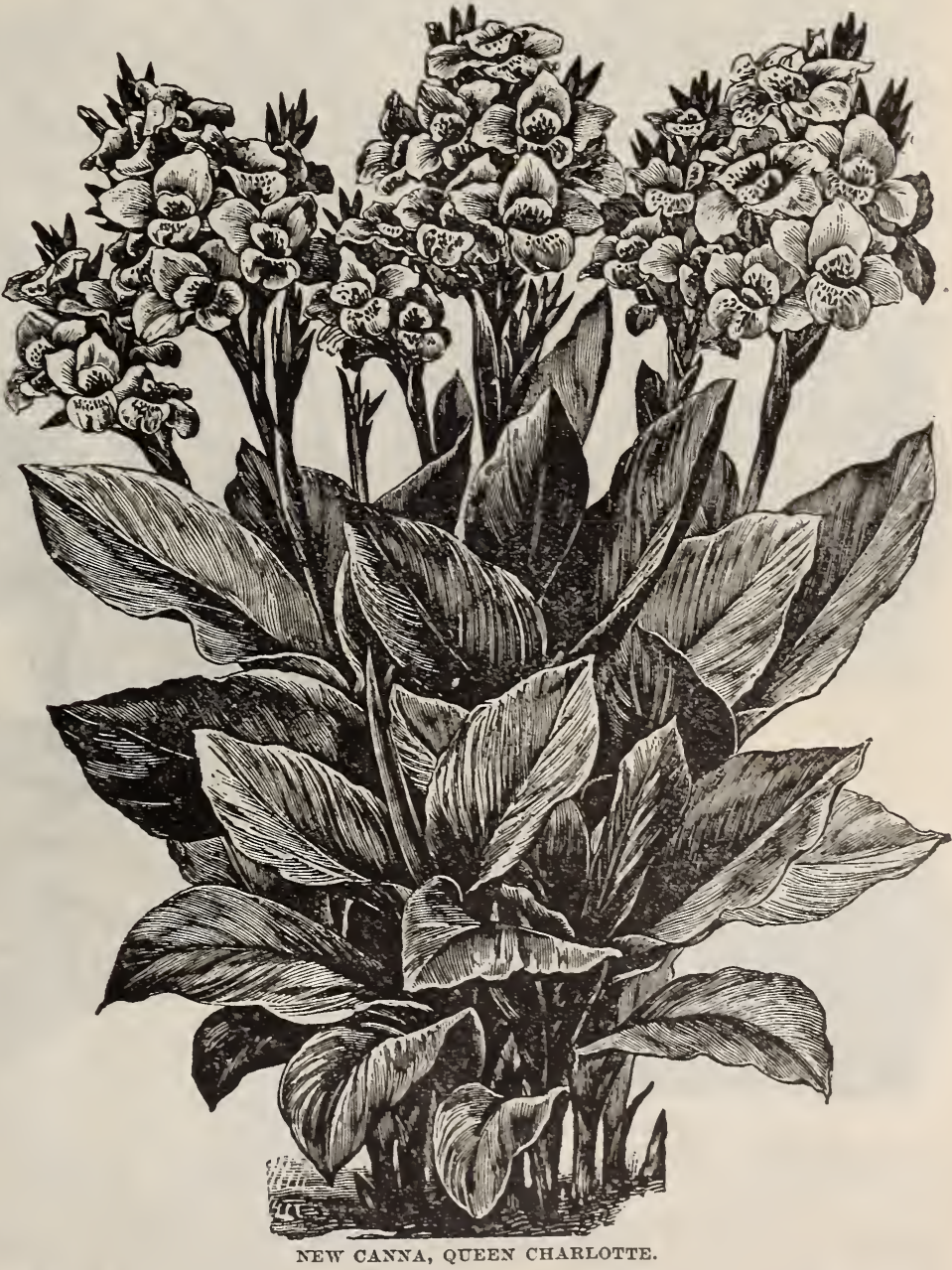

The Beautiful New Spotted Canna,

FLORENCE VAUGHAN

Conceded by all who have seen it to be the finest rellowspotted Canna. Flowers very large, of the most perfect form, with broad, overlapping petals, nicely rounded at the ends. Color brilliant jellow, spotted with bright red. A strong, robust grower, and flowers very freely. Price, 10 each.

The New Salmon-Colored Canna.

\section{PAUL MARQUANT}

The individual flowers are large, and the flowers' spike very large, each flower standing ont separately by itself. The color is vers hard to describe. It might be described as a bright salmon with a carmine tint. Price, $10 \mathrm{c}$ each.

\section{Rich Crimson-Flowered Canna,}

\section{CHARLES HENDERSON}

A splendid dwarf, compact grower, throwing up direct, compact heads of blooms of immense size. The indiridual flowers are among the very largest. Color, dark crimson. center of the flowers marked with gold pencilings. One of the very finest varieties. Price, $10 \mathrm{c}$ each.

The Stately Dark-Leared Canna,

\section{EGA NDALE}

One of the finest dark-leaved Cannas for bedding that has zet come under our notice. The foliage is good, habit sturdy. Flowers of good size borne in compact heads. The color is a deep currant-red, different from any other. Price, $15 \mathrm{c}$ eash.

The Grand Bedding Canna, BEA UTY POITEVINE

Bright, rich crimson, growing 3 to $31 / 2$ feet high, stands d Buth and heat better than any other variety. A fine bedding Cann having bright green foliage and good sized trusses of flowers on erect flower spikes. Price, $15 \mathrm{c} \mathrm{each}$. 


\section{TEN GIANT FLOWERING HIBISCUS}

Price, 10 cents each; any three for 25 cents.

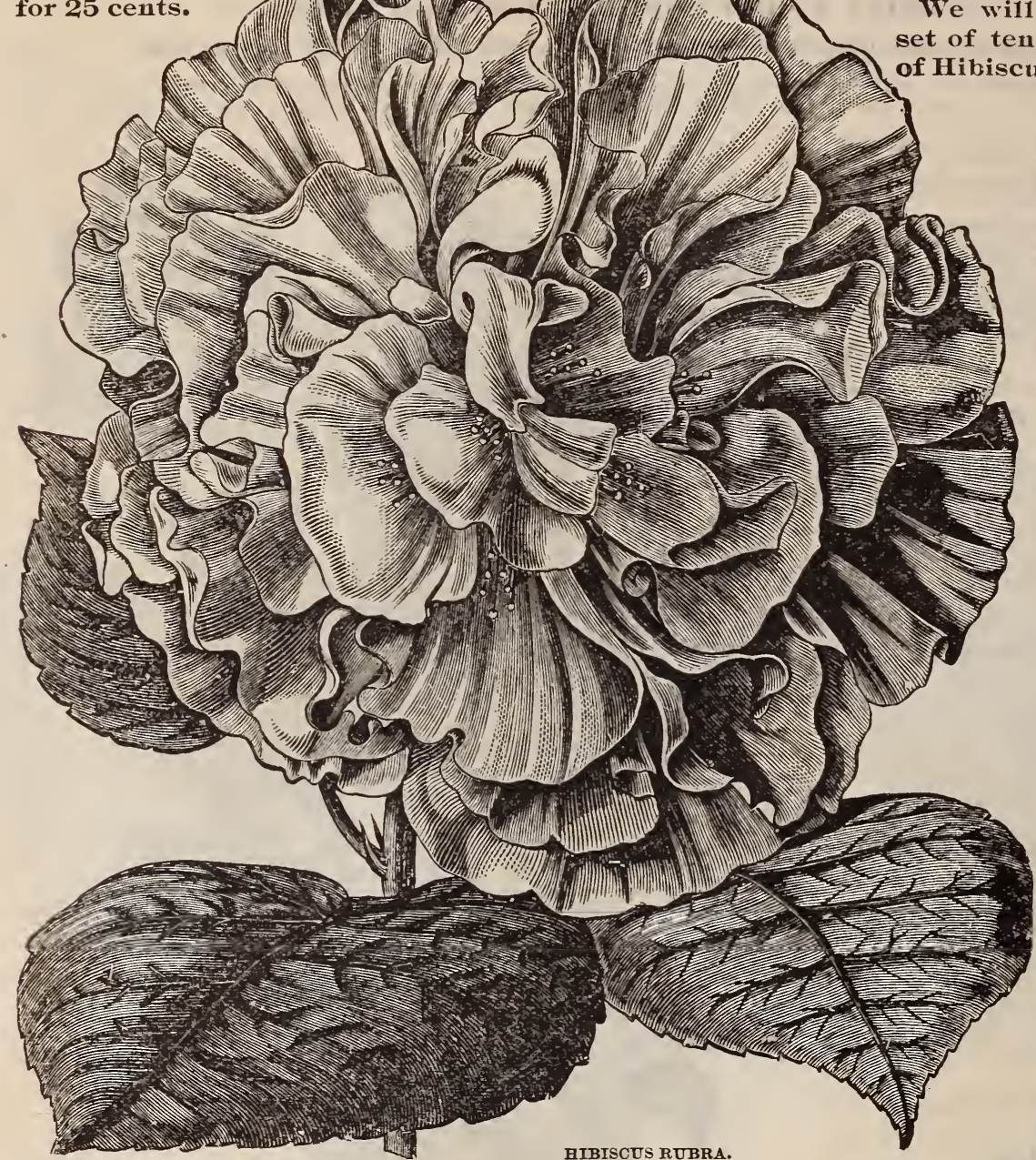

Grandiflorus.

Rich, glossy foliage, blooming profusely through the Summer, literally covering the plants with scarlet crimson single flowers. $10 \mathrm{c} \mathrm{each}$.

Double Hibiscus Zebrinus.

Petals scarlet, edged and striped with creams-rellow and white. A unique variety. $10 \mathrm{c}$ each. Collerii.

Flowers buff-yellow with a crimson-scarlet base. Peculiarly handsome. $10 \mathrm{c}$ each

\section{SPECIAL OFFER.}

We will send the full set of ten best varieties

Large growing tropical plants with very glossy foliage. The plants under the hottest sun, produce enormous flowers in great numbers, and make noble speci. mens. They can be grown in tubs and kept for years. The blossoms average five or six inches in diameter, and are gorgeously colored.

\section{Aurantica}

Large, double. orange-colored flowers; early and profuse bloomers. 10c each.

Carminatus Perfectus.

Full, round flowers of perfect shape and of a rich, soft, carmine rose, with a deep crimson eye. A beautiful free blooming variety $10 \mathrm{c}$ each.

\section{Decorus.}

Foliage very large and lobed; flowers enormous, on long stems, of a beautiful rosy-carmine color: the stamens and pistils are very showy; the stigma is large, yellow. 10c each.

\section{Sub-Violaceous}

Flowers of enormous size, of a beautiful carmine tinted with violet; probably the largest flower of the Hibiscus family. $10 \mathrm{c}$ each.

Rosa Sinensis.

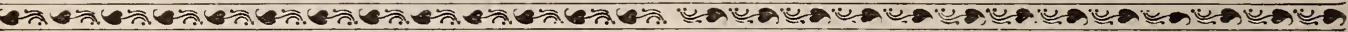

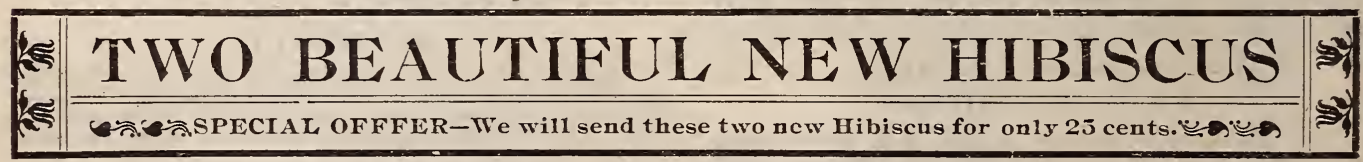

$$
\text { New } \text { Hibcus, PEACHBLOW. }
$$

This is one of the finest plant novelties offered in recent years. The flowers are double, and from 4 to 5 inches in diameter. Color a clear, rich pink, with a small, deep crimson center, an entirely new and most beautiful shade. Price, $16 \mathrm{c}$ each.
Flowers red and very large, averaging nearly five inches in Rubra.

A magnificent double variety, with large red flowers. $10 \mathrm{C}$ each.

Gen. de Courtigis. A very grand, large-sized flower; single, light scarlet; very 
A Magnificent Hardy Climbing Vine,

\section{The Mountain Beauty Or, "Queen's Wreath."}

(Antigonon Leptopus.) Is absolutely hardy, and once planted is practically everlasting. The foliage, as well as habit of growth resembles Ampelopsis Veitchi, one of the most popular and valuable of hardy climbers. It surpasses Ampelopsis Teitchi, however, inasmuch as it produces imThe flowers are borne in prodigious profusion. Price, 10c each; three for $25 \mathrm{c}$.

The Latest Novelty in Hardy Plants,

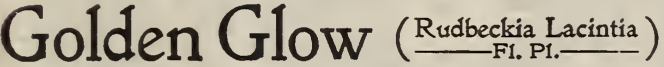

A magnificent, hardy, perennial plant growing eight feet high; branching freely, bearing by the hundreds on long, graceful stems, exquisite double blossoms of the brightest golden color, large as Cactus Dahlias. It grows vigorously, and throws up strong branching flower stems six feet high, laden with sheaves of golden blossoms as large as fair Chrysanthemums. and all having an elegant, graceful appearance without any of the stiffness in habit or blossoms peculiar to sunflowers. As cut flowers the blossoms last well. Most effective flowering plant for August and September cultivation. Price, strong plants which will bloom freely this season, $10 \mathrm{c}$ each; three for $25 \mathrm{c}$.

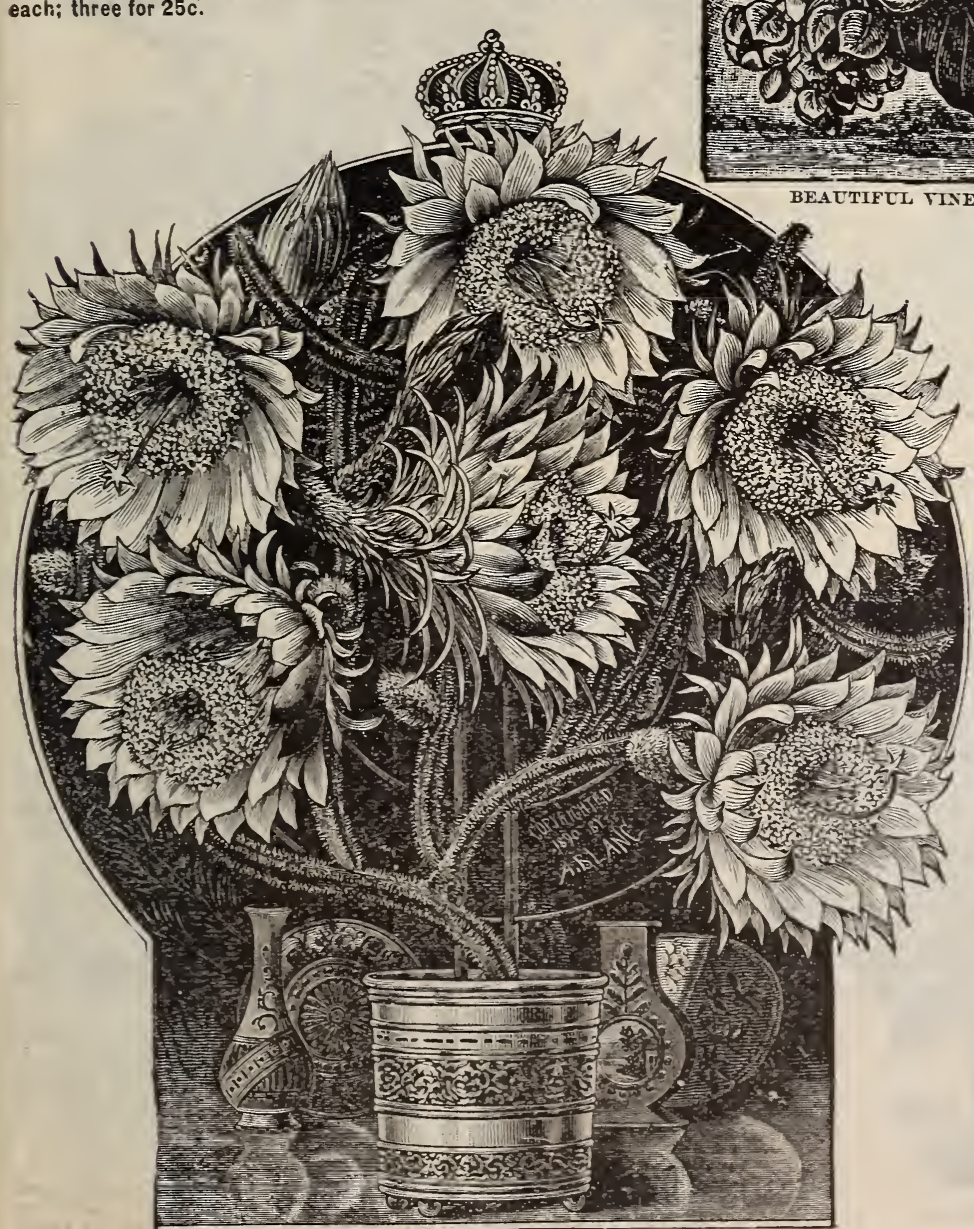




\section{Our Magnificent Dew Bedding Jerbenas. \\ MAMMOTH BLOOMS AND GORGEOUS COLORS.}

\section{OUR SPECIAL OFFER-FOr 50 cents we will send twelve choice Mammoth Verbenas, in splendid variety. These will make a beautiful bed and will be a mass of bloom all Summer.}

Verbena, Mammoth Flower ing-In this grand new strain has been developed a mammoth Verbena that produces uniformly magnificent large trusses, with flowers of unusual size and of a wide range of colors. The individual blossoms are frequently larger than a silver quarter. Take a quarter and try to cover any of the single flowers of the corymb, and jou will realize how magnificent in size are the single florets. Our plants are in splendid condition, strong and healthy. being grown in a very cool temperature, and include all the beautiful show colors which characterize this hand some bedder. Price, $8 \mathrm{c}$ each; 5 for $25 \mathrm{c}$. New Pure White Verbena Mrs. McKinley-This is the most beautiful of all the white large flowering Verbenas. Price, $8 \mathrm{c}$ each.

New Striped Nammoth Verbeua, "Zebra"-This is a most beautiful variety, very large and striped white on a red ground. See cut. Price, $10 \mathrm{c}$ each.

New Blood Red Verbena, "Dazzler"-This is without doubt the most brilliant colored of any flower that grows. It is very large and such a vivid red that it really dazzles the eye to look at it. Price, $8 \mathrm{c}$ each.

New Pink Yerbena, "Peerless"-A magnificent Verbena, extremely large, soft glowing pink. Price, $8 \mathrm{c}$ each.

New Blue Verbena, "Blue Boy"-As the name implies it is a magnificent, large flowering blue variety. It is indeed a beauty. Price, $8 \mathrm{c}$ each.

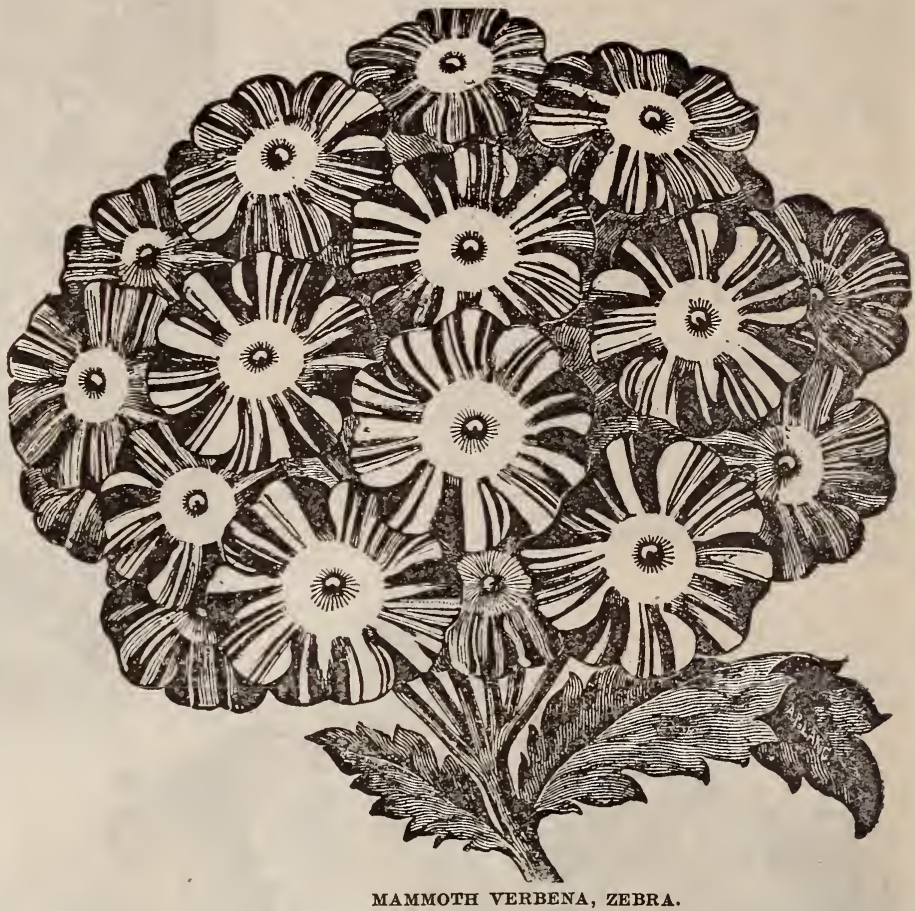

New Mammoth Verbena, "Royal Purple"-This is a grand and beautiful sort, very large and free flowering, Color a rich shade of purple. Price, $8 \mathrm{c}$ each.

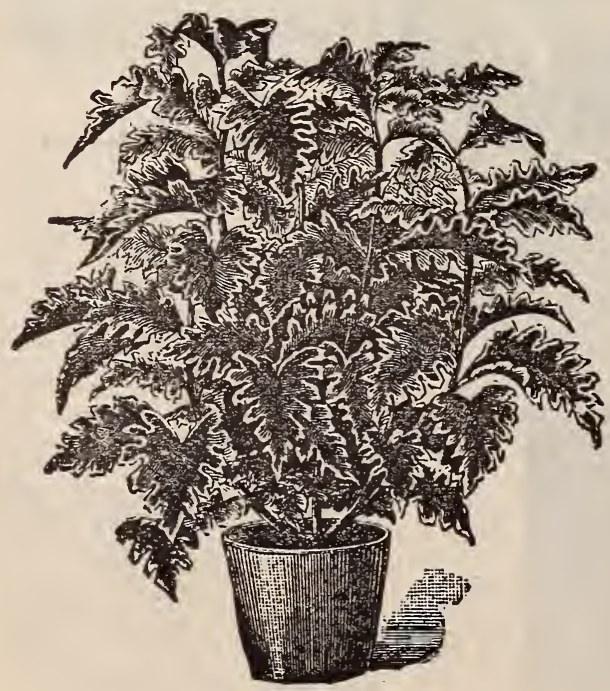

COLEUS IN SIX INCH POT.

\section{Our Beautiful Dew Bedding Coleus}

OLEUS represents more colors in their variegation than any other plant. They are certainly the most popular of colored foliage plants. Whether grown as single specimens or in masses of ribbon lines, they are equally attractive. They are of the easiest culture and well adapted to our climate, flourishing in the hottest sun, as well as displaying their beautiful colors in the shady ful colors in the shady corner, where hardly any other plant Would do. Plants should be set about a foot apart, so that when plants are needed of each kind in a row. All are good bedders and will stand the hot sun without losing their brilliant coloring. Price, $6 \mathrm{c}$ each.

\section{- H Big Bargain in Coleus.}

We will send ten distinct new sorts for 50 cents; twentyfour distinct sorts for $\$ 1.60 \mathrm{by}$ mail, postpaid. If ordered by express we will send thirty for $\$ 1.00$. We can supply leading bedding Coleus, in good variety, at \$2.50 per hundred by express.

\section{NOTE}

Some varieties of Coleus make beautiful pot plants if kept pinched back so as to make them grow bushy. We will send five beautiful sorts, suitable for growing in pots, for only 25 cents. 
The Lovely, Everblooming

PAIRIS DAISIIES OR MARGUERITES

Tew Paris Daisy, Mad. Gailbert-(Marguerites.) This is one of the finest new plants that guerites.) ined that is finer. All know the old varieties of Paris Daisies, how beautiful and much sought after for decoration of all kinds. This new rariety blooms constantly and will produce ten blooms to the older variety's one. Nothing is so airy and graceful as these blossoms of large white petals, showing a vellow disk. Price, $10 \mathrm{c}$ each; three for $2 \mathrm{sc}$.

Etoile de Or-(Marquerite, The new sellow Paris Daisy, similar to the above, but a rich golden color. The two varieties go handsomely together. Price, 10 cents each; three for 25 cents. The two varieties for 15 cents.

We advise our customers to plant these Daisies largely. A half dozen or dozen plants will be a constant source of delight.

\section{THREE SPLENDID OLEANDERS}

\section{Yellow, White and Pink.}

Nothing nicer for porch or lawn decoration. Give good lich soil and plenty of moisture during growing season. May be wintered over in any cellar were it does not freeze.

Iadonna Grand iflora-Large flowered double white. This is a beautiful sort and is always scarce. We have a very fine stock of them. Price, nice plants, 10c each; large plants from four-inch pots, $25 \mathrm{c}$ each.

Yellow Oleander-(Lutea.) A new and scarce variety, with light, yellow-colored blossoms. A decided novelty. Price. nice plants, $10 \mathrm{c}$ each; large plants from four-inch pots, $25 \mathrm{c}$ each.

Oleander Rose Queen-The oldest and finest of all varieties in cultivation; flowers double and rose colored. Price, nice plants, 10c each; large size $25 \mathrm{c}$ each.

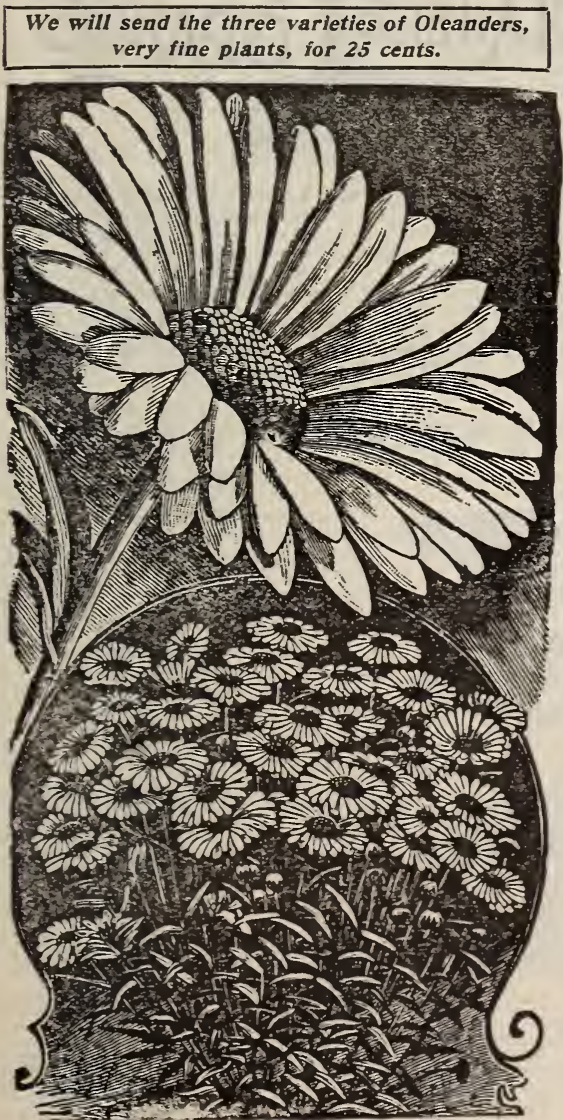

EVER-BLCONING PARIS DAIST.

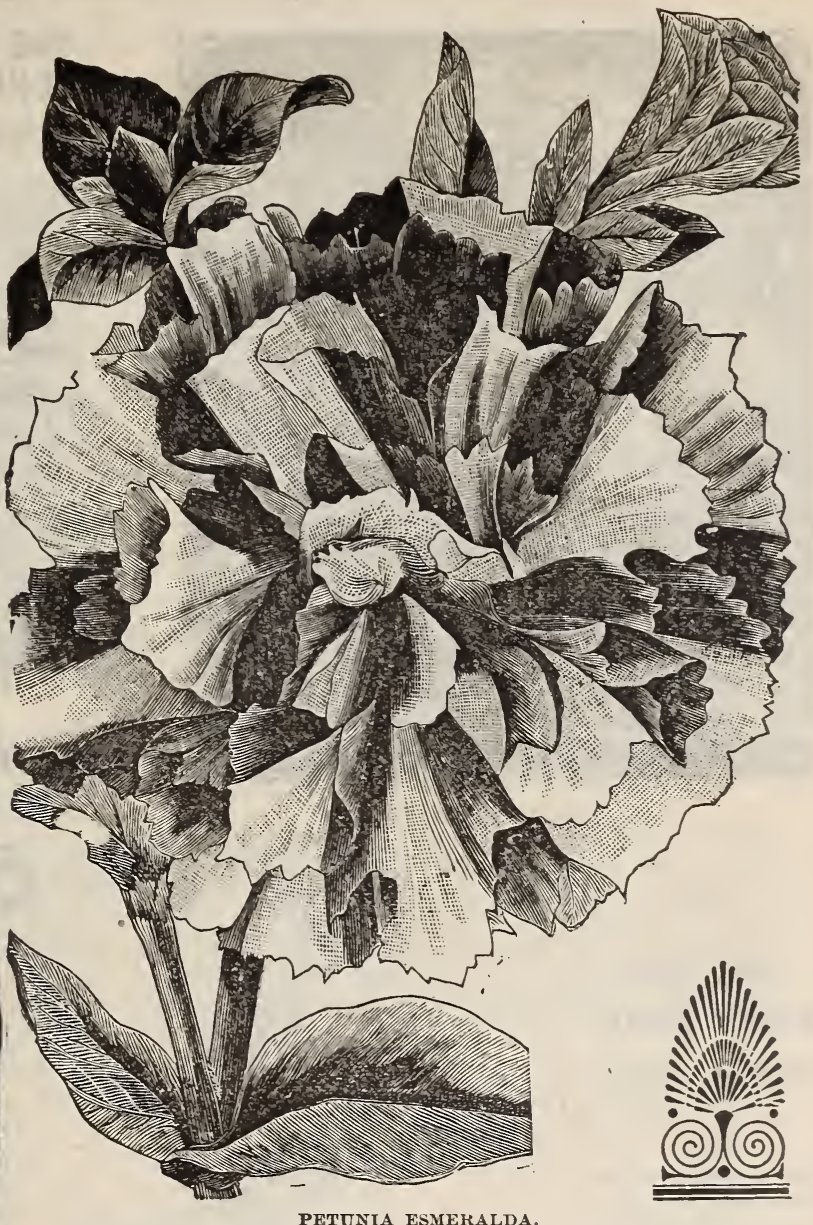

OUR NEW PRIZE STRAIN

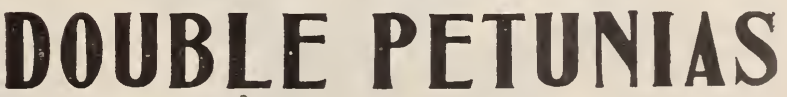

The Grand, New,

Variegated Double Petunia Esmeralda.

This splendid Petunia is one of the very largest and best of the new, large-flowering varieties. It is a strong grower and free bloomer, and is beautifully variegated purple and white. Price, 10 cents each.

\section{The Charming, New}

\section{Mottled Double Petunia Excelsior.}

This is another handsome and showy varietr, exceedingly double, a robust grower and profuse bloomer. Price, 10 cents each.

\section{The Pure White}

\section{Double Petunia Searoam.}

A lovely new Petunia, very large; nicely fringed, pure white and always in bloom. Price 10 cents each.

OUR SPLENDID OFFER - We will send these three handsome new Petunias, nice plants, for only 25 cents. 


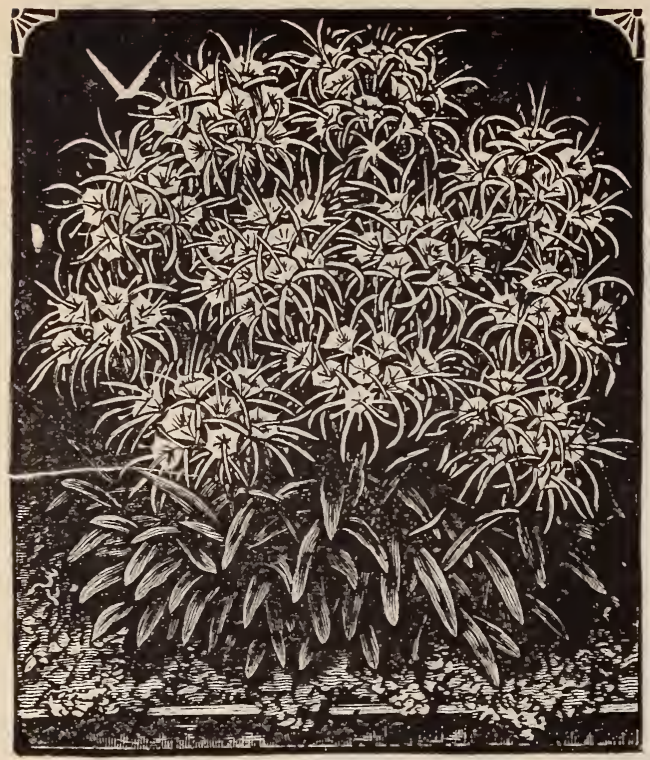

WHITE SPIDER LILY.

$$
* *
$$

THE NEW

\section{HARDY WHITE}

SPIDER LILY.

This grand new

Spider Lily has the advantage of being perfectly hardy, and when left undis turbed a few years forms large imposing clumps that are a mass of clustered heads of pure white, fragrant fl ow ers. The flowers have a peculiar, striking beauty, which must be seen to be appreciated. The flower: are borne in large clusters, are of waxy whiteness and unsurpassed fragrance More beautiful than most of the highpriced Lilies. An ex tra choice garden flower which we cannot too strongly recommend. Also a fine pot plant. Fine flowering bulbs, 20c each; three for $50 \mathrm{c}$.
THE BEAUTIFUL AND FRAGRANT CHINESE OR OTAHEITE ORANGE.

BLOOMS AND FRUITS WHEN QUITE SMALL.

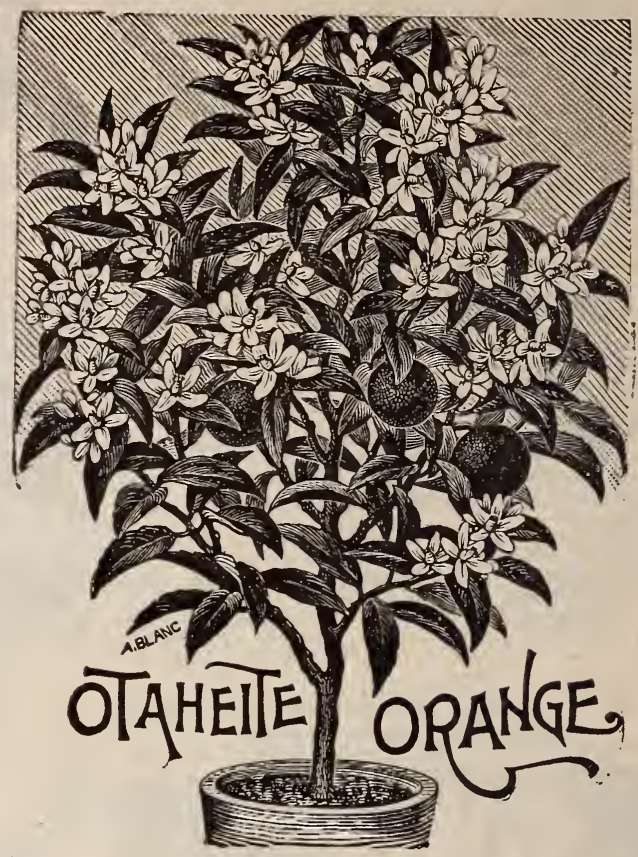

A dwarf Orange, which grows, blooms and fruits freely in pots. The fruit is about one-half the size of ordinary Oranges and very sweet and delicious. Blossoms are produced in great abundance. Blooms freely during Winter, though likely to bloom at any time. The plants we offer are strong, and can be ready to bloom and fruit the coming Winter. Price, fine young plants, $10 \mathrm{c}$ each; large size, $25 \mathrm{c}$ each. Extra large fruiting size out of five and six inch pots by express only 50 and 75 cents each.

NEW PINK JAPANESE SPIDER LILY.

The white Spider Lily pleases every one so well after being brought to their notice that this bright colored variety cannot fail to create a great sensation and become immensely popular. A clump of bulbs produces a large number of spikes of the most delicate flowers, varring their colors from a pinkish-salmon to pink, while many sorts produce a deep scarlet. Tho petals are beautifully undulated, and by an artificial light they sparkle like jewels. The bulbs are not as large as the white variety. Price. $20 \mathrm{c}$ each; three tor 50 cents.

THE LOVELY SMILAX

\section{- . VINE - .}

This very great climber is a great addition to basket plants. possessing the rare qualities of delicate and tolerably dense foliage and vining habit. For using for a green with cut flowers it has no equal, its hard texture enabling it to keep several days without wilting after being cut. It is also fine as a parlor or window plant. Price. $6 \mathrm{c}$ each; three for 15 cents. 


\section{A Page of Rare Foliage and Flowering Plants}

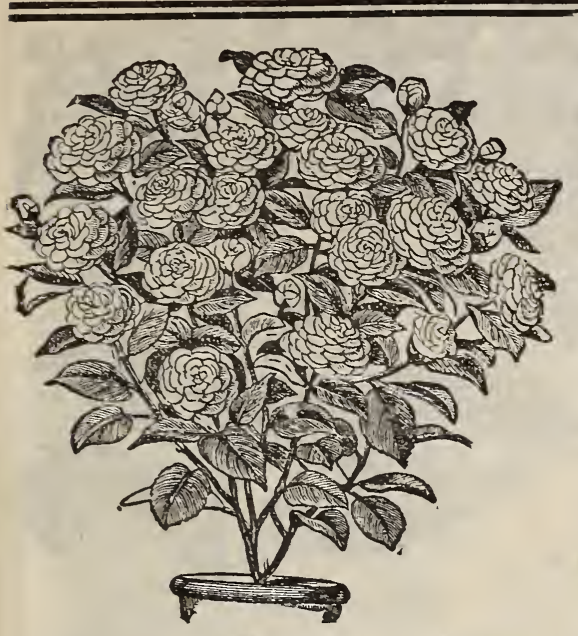

CAMELLIA JAPONTCA.

Ghe Royal Plant,

\section{CAMELLIA JAPONICA}

The royal family of greenhouse plants. Leares glossygreen and flowers of the most exquisite beauty and waxy texture. From pure white to crimson in almost endless variegation. The pure white ones are generally prized above the colored varieties. Their culture is nearly related to that of the Azalea, but their success is more certain. Requires shade and moisture throughout the hot season. Their time of blooming is Winter and early Spring. Requires a moderate and uniform temperature with as little artificial heat as possible. When set with flower buds great care must be taken in watering-when left too dry the buds are sure to drop. We have a fine assortment. Price, for very large, strong plants, by express, $60 \mathrm{c}$ and $75 \mathrm{c}$ each.

\section{The Grandest of all Decorative Plants,}

\section{$A R A U C A R I A$ EXCELSA, (Norfolk Island Pine)}

Various names have been selfeted for this grand plant to properly convey to the mind the appearance of it. Some have called it the "Christmas Tree Palm" from its resemblance to a Christmas tree; others hare called it the "Star Palm," because the leaves are arranged to form a perfect star, but no descriptive name can give any adequate idea of its beauty. It has deep green, feathery foliage, arranged in whorls, rising one above the other at regular distances; its symmetry of form, grace and beauty of foliage are unequaled in the vegetable kingdom. It is easily grown in the house and is highly ornamental. Extra fine plants, 4 and 5 tiers of leaves, $\$ 1.50$ each. These can only be sent by express. Nice plants, 3 or 4 tiers of leares, $\$ 1.00$ each.

\section{FICUS ELASTICA, (India Rubber Gree)}

Vert large, smooth, leathery leaves, evergreen foliage. Generally esteemed one of the finest house plants grown, the plant attaining a large size and tree shape. Each new leaf is enclosed in a long, coral-red enrelope, looking like a great red flower bud. 'Price, fine plants, $50 \mathrm{c}$ and $75 \mathrm{c}$ each. See cut.

The Grand Mew Hardy Blood Red Peong (Piney)

$$
B A N D I T \text {. }
$$

This is a splendid new variety of this favorite hardy garden plant. The flowers are of immense size and of : brilliant red color. It is quite hardy, very double, and the freest blooming of all the Peonies. Price, strong blooming roots 25 cents each; three for 50 cents.

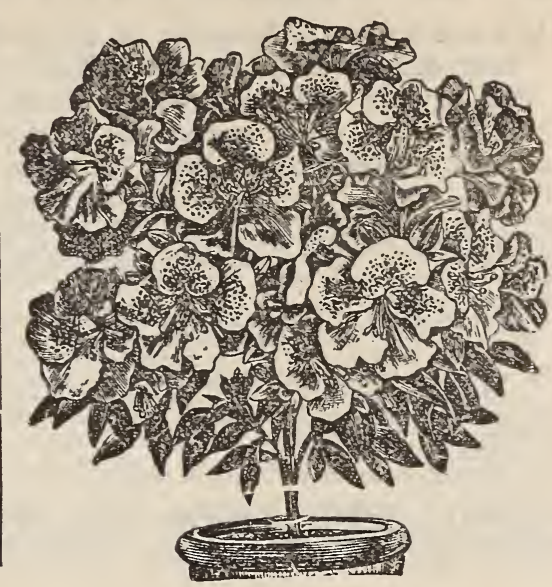

AZALEA INDICA.

\section{AZALEA INDICA}

One of the most gorgeously blooming families, together with the showiest of all greenhouse plants. The colors of the flower vary from the purest white to the deepest crimson in untold variations. The soil should always be packed hard when transplanted. Their success depends, however, on the degree of moisture in the atmosphere in which they live. WV have a number of the best flowering sorts that will flower finely this coming. Winter, both double and single flowered, in any color desired. The plants we offer are magnificent specimens, the finest you have erer seen, and all will bloom this year. Price, fine large plants, three years old, $75 \mathrm{c}$ each. Must be sent by express.

N. B.-Besure and try our Azaleas. They will not disappoint you. In ordering name the color you wish. We can furnish them in the following colors: White, pink, crimson, salmon, rosy-lilac, and white striped with crimson.

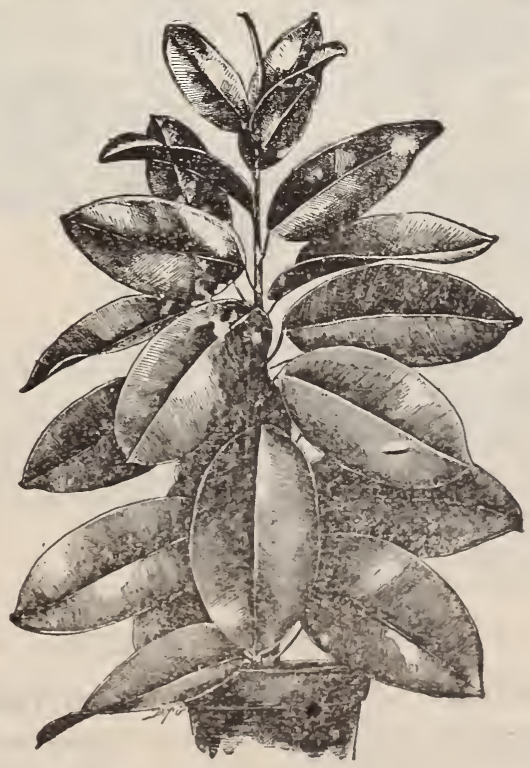

FICUS ELASTICA-RTBBER PLANT. 


\section{FRAGRANT * * $\%$ * * HELIOTROPES}

These are universal favorites on account of their delightful fragrance. Flowering equally well as bedding plants in Summer or as pot plants in the house during Winter. Price, $10 \mathrm{cEach}$.

Albert Delaux-A French variety of great beauty. Foliage is a bright golden-yellow, very pronounced, and marked slightly with delicate green. In bloom it is exquisitely beautiful, the deep lavender color of the flower Very free flowering.

Snow Wreath-The nearest approach to pure white we have in the Heliotrope. Exquisite fragrance. irope, with large trusses of violet flowers with light center. Madame Bruant-One of the finest we have ever mense panicles of very large flowers; rich purple, with large white eye.
Florence Nightingale-Dark lavender. Fine.

WE WILL SEND THESE FIVE BEST HELIOTROPES FOR 40 CENTS.

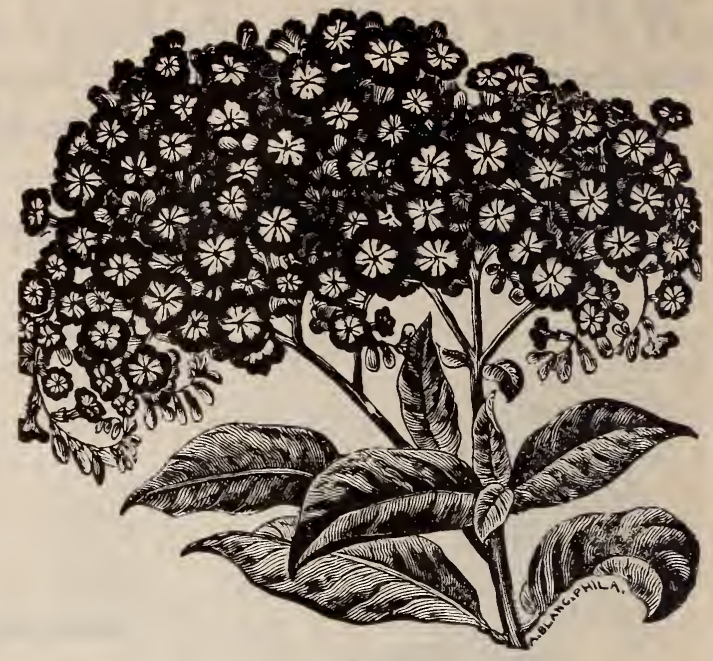

MADAME BRUANT.

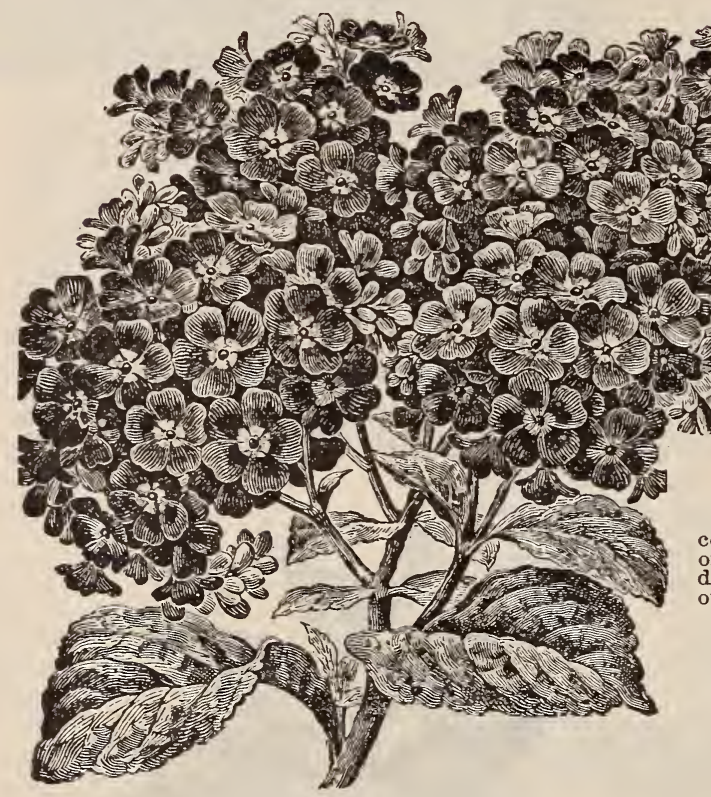

NEW HELIOTROPE PICCIOLA.

\section{SUMIMER-FLOWERING OXALIS.}

They are very effective in masses or beds, and are particularly valuable for edgings. The bulbs, when planted three inches apart, produce an unbroken row of elegant foliage and pretty flowers. The bulbs, which are the size of peas, or larger, planted the first of May, or earlier, will flower by the first of June, and will furnish a neat and attractive border the whole season. They are also very beautiful grown in hanging baskets.

Dieppi-Pure white.

Lasandria-Rosy pink.

Purpurea-Fine purple.

* PRICE 20 CENTS PER DOZEN. * ALOYSIA CITRODORA, Lemon Verbena.

Indispensable for the delightful fragrance of its leaves in the construction of bouquets, etc.

PRICE, 10 Cents Each.
6.:-

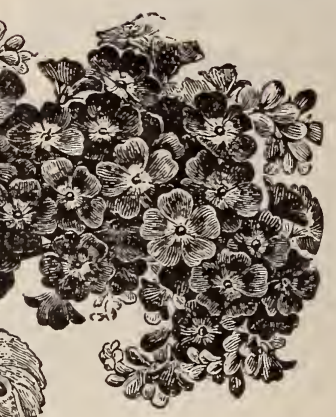

PICCIOLA.

Rosy-violet, indeed almost a red, with a distinct white center, showing upright growth, producing immense heads of flowers well above the foliage; flowers do not have that drooping appearance that is so much against some of the other varieties.

\section{GERBE FLEUR.}

Large trusses, nearly pure white. A magnificent variety.

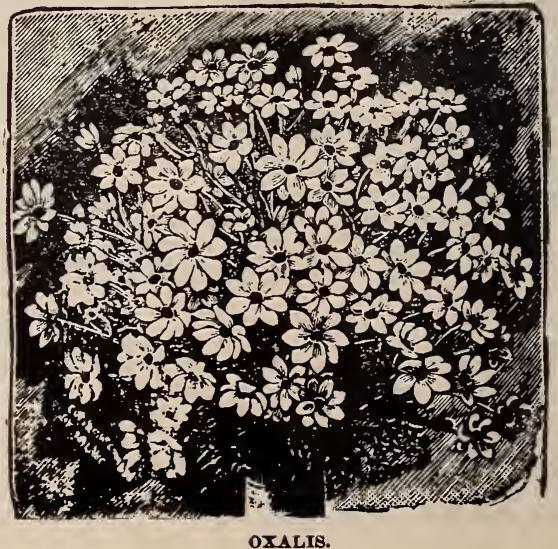




\title{
THREE BEAUTIFUL PLUMBAGOS
}

$\bar{\equiv}$ LIGHT BLUE, PURE WHITE, AND DARK BLUE

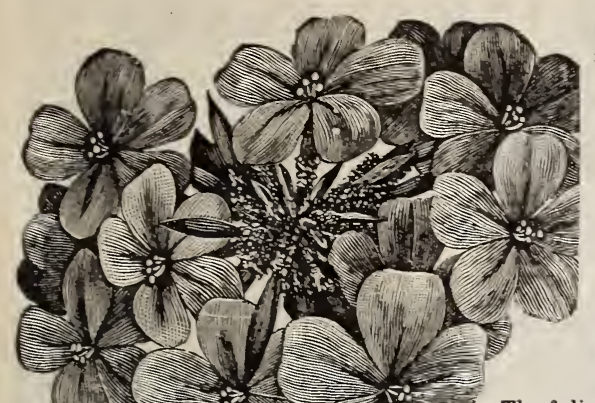

PLUMBAGOS The Plumbagos are always satisfactory plants, PLUMBACOS either for pot culture or for the garden. They are flowers are very useful for cutting.

Capensis Alba-The counterpart of Plumbago Capensis, excepting in color, which is creamy white. A constant bloomer. A splendid new sort. Price, 10c each.

Capensis-A well-known favorite, and always valuable because it produces large trusses of beautiful light blue flowers. Price, $10 \mathrm{c}$ each. see cut.

The Hardy Plumbago Lady Larpent-This beautiful variety of Plumbago (P. Larpentæ) is unuable hardy herbaceous plant now in cultiration. The plants are strong, upright in habit, growing to a height of 12 to 15 inches in compact clumps, and from the middle of July until serere frost are covered with rich, riolet blue colored flowers, borne in close terminal heads. The foliage is unique finely serrated and fringing the stems. Te heartily recommend this tine rariety for edging walks, beds or borders, or single specimens set in mixed flower rases or beds, where they appear in lovely contrast with ther flowers. Price, $15 \mathrm{c}$ each.

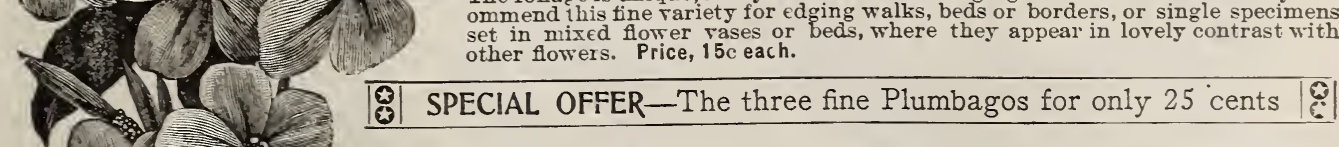

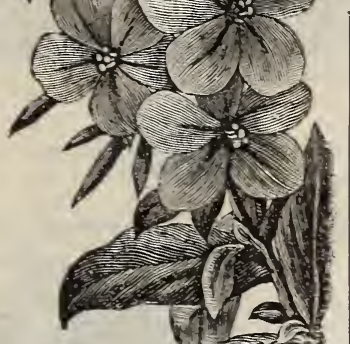

BLUE PLCARBag CAPENSIS.

\section{TWO BEAUTIFUL DECORATIVE PLANTS}

\author{
INDISPENSABLE TO THE WINDOW GARDEN
}

NEW SPRENGERII A desirable

ASPARAGUS SPRER

ful as a pot plant or for baskets; fronds frequently 4 feet long; a rich shade of green, retaining freshness for weeks after cutting; fine house plant, as it withstands plants, 20c each.

SPECIAL OFFER We will send one each of Asparagus in large size for only 30 cents.

\section{ASPARAGUS PLUMOSUS NANUS}

One of the handsomest of our foliage plants. The leaves are a bright green, gracefully arched, and as finely woren as the finest silken mesh. Their lasting qualfry when cut is remarkable, retaining their most raluable plant we have for this purpose, surpassing the Maiden Hair Fern in grace, fineness of texture, and richness of color. See illustration. Price, 10c each; extra large plants, $20 \mathrm{c}$ each.
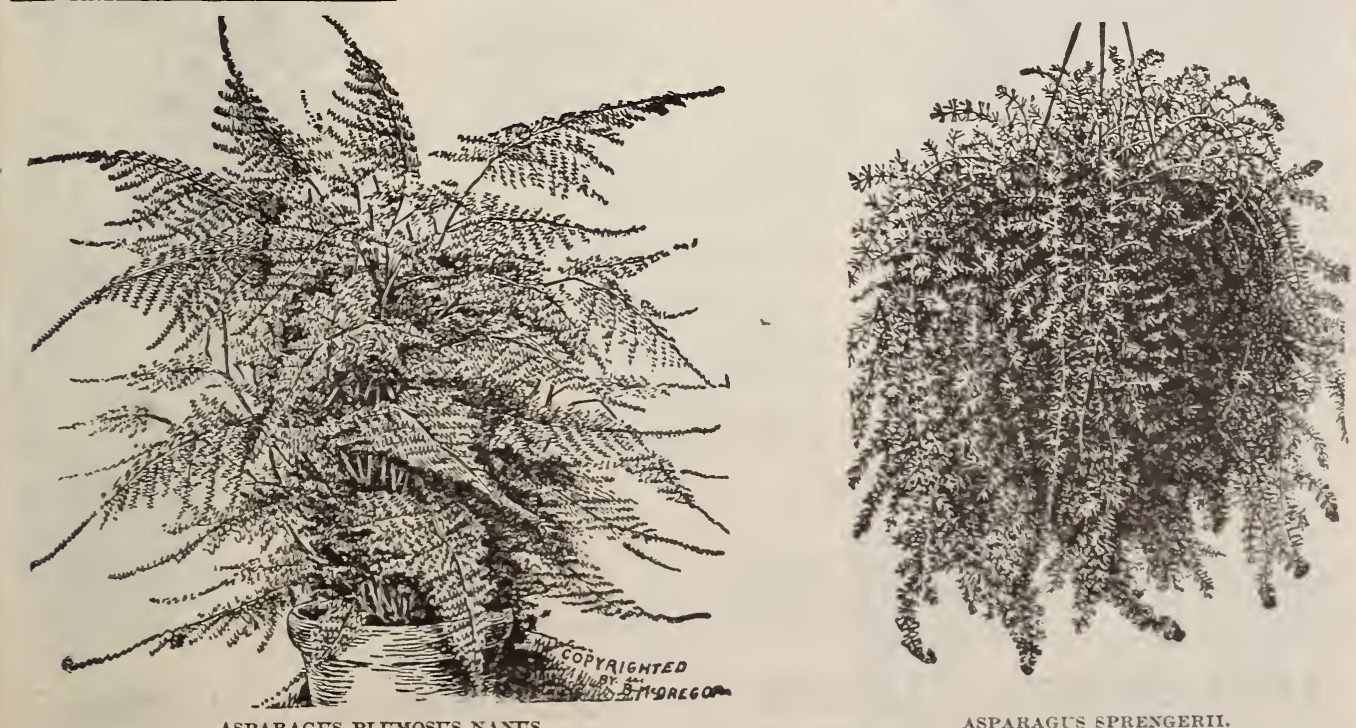

ASPARAGES PLCMOSES NANTS.

ASPARAGT'S SPREXGERII.

Our Asparagus Sprengerii and Plumosus Nanus are exceptionally fine, and will 6. $\sigma^{\circ} \sigma^{\circ}$ make handsome specimen plants iu a very short time. $\sigma^{\circ} \sigma^{\circ}$ 


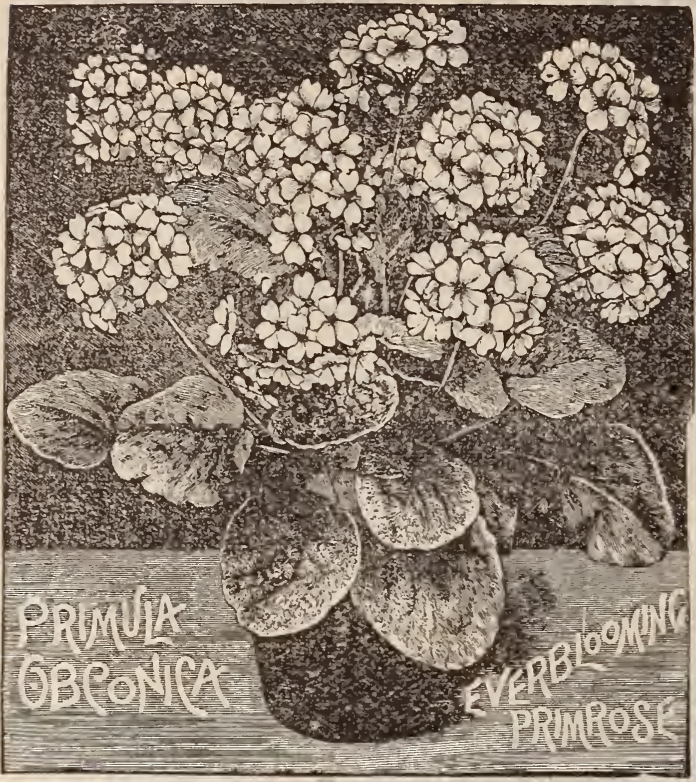

\section{ALYSSUMI (}

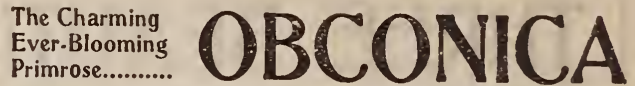

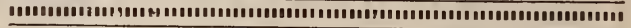

\section{PRIIIULA OBCONICA}

A lovely perpetual blooming Primrose and admirably adapted to growing in a cool climate. The flowers are not large, but are profusely borne in loose trusses, and are of a delicate rosy lilac, shading to white, and possess the true Primrose fragrance. It is in bloom fully nine months in the year, and some plants have kept up a succession of bloom during the entire season. Price, $10 \mathrm{c}$ each.

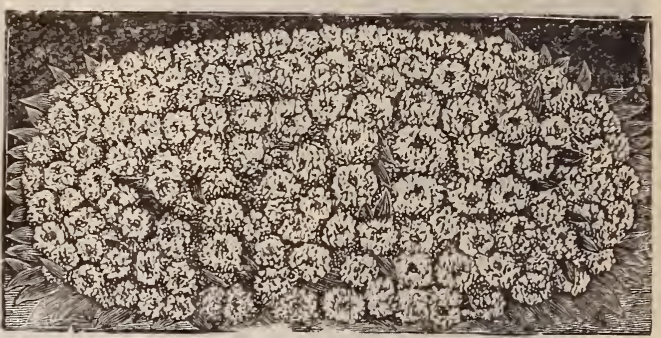

SWEET ALYSSUM.

A very great advance on the single alyssum. It is indispensable as a cut flower, being a beautiful white and very fragrant. Continues in bloom until November, as light frosts do not injure it. Price, 8c each; $50 \mathrm{c}$ per dozen.

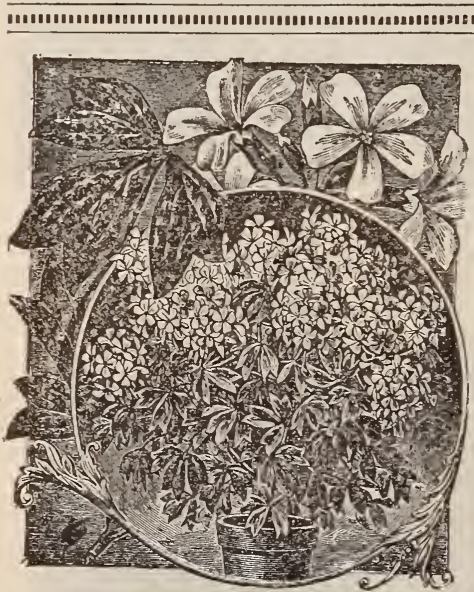

New Golden-Flowered, Ever Blooming Oxalis

\section{OXALIS ORTGIESI}

It is a shrubby plant, like a Geranium or Fuchsia, without buds, in which re spect it differs from other Oxalis. It ing freely and loaded at all times with clusters of bright, golden, star-shaped flowers, which do not close at night, like other Oxalis. The leaves are threelobed, dark olive-green above and a beautiful, shining, metallic crimsonpurple underneath; wine-colored stems. Price, $15 \mathrm{c}$ each; three for $30 \mathrm{c}$.

\section{IVY CANARIENSIS English Ivy}

An excellent variety for cultivation in the house, being a free grower, and very beautiful, broad, glossy green leaves. Price, $10 \mathrm{c}$ and $20 \mathrm{c}$.

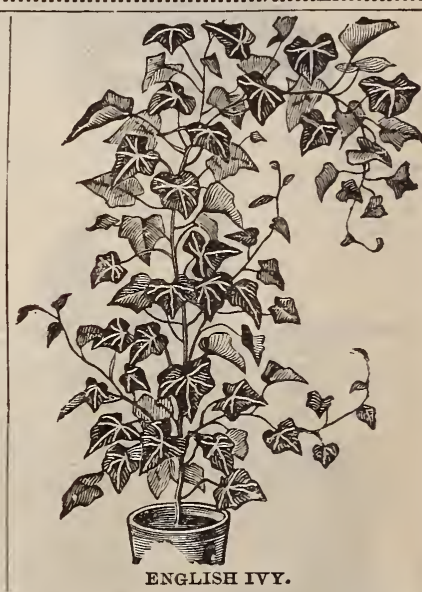

THE GOLDEN EVER BLOONING OYALTS.

\section{MAGNOLIA FUSCATA}

Banana Shrub.

A most desirable greenhouse shrub, succeeding admirably as a window plant. It produces its brownish yellow flowers in the greatest profusion during late Winter or early Spring months. Th se are of the mo:t exquisite fragrance, similar to a ripe banana. Large strong plants, $40 \mathrm{c}$ each.

\section{CLERODENDRON BALFOURII}

A plant of great beauty. Makes a grand bedding plant where both foliage and bloom are desired. The flowers, which are of a bright scarlet, are encased by a bag like calyx of pure white, the trusses or panicles of flowers are upwards of six inches in length, and when trained upon trellises and hanging down have a rich and elegant appearance. $15 \mathrm{c}$ each.

\section{OLEA FRAGRANS}

\section{Sweet Olive.}

An old favorite greenhouse shrub, succeeding admirably as a house plant, producing small white flowers which are of the most exquisite fragrance, continuing to bloom almost the entire Winter. Nice strong plants, 35c each.

\section{DICENTRA SPECTABILIS}

\section{Bleeding Heart.}

A hardy perennial plant with rose-colored flowers in great abundance. One of the best border plants. Perfectly hardy and easily cultivated. Two feet high. Flowers in April and May. 20c each. 


\section{Linum Trigynum.}

A winter-blooming plant of great beauty, croducing in the greatest profusion very arge and very showy blooms of a bright yellow color. The plant is a complete mass of bloom for a long timeduring winter, and is one of the most beautiful winter bloomers it is possible to have. The flowers are about the size of a Morning Glory, and no matter how small the plant is it will bloom profusely, and each year as it grows into size it becomes more beautiful. Price, 10c each.

\section{Achania Malvaviscus.}

A vigorous growing plant, resembling the Abutilons in habit and growth, valuable alike for bedding or pot culture, blooming profusely throughout the entire year; flowSee cut.
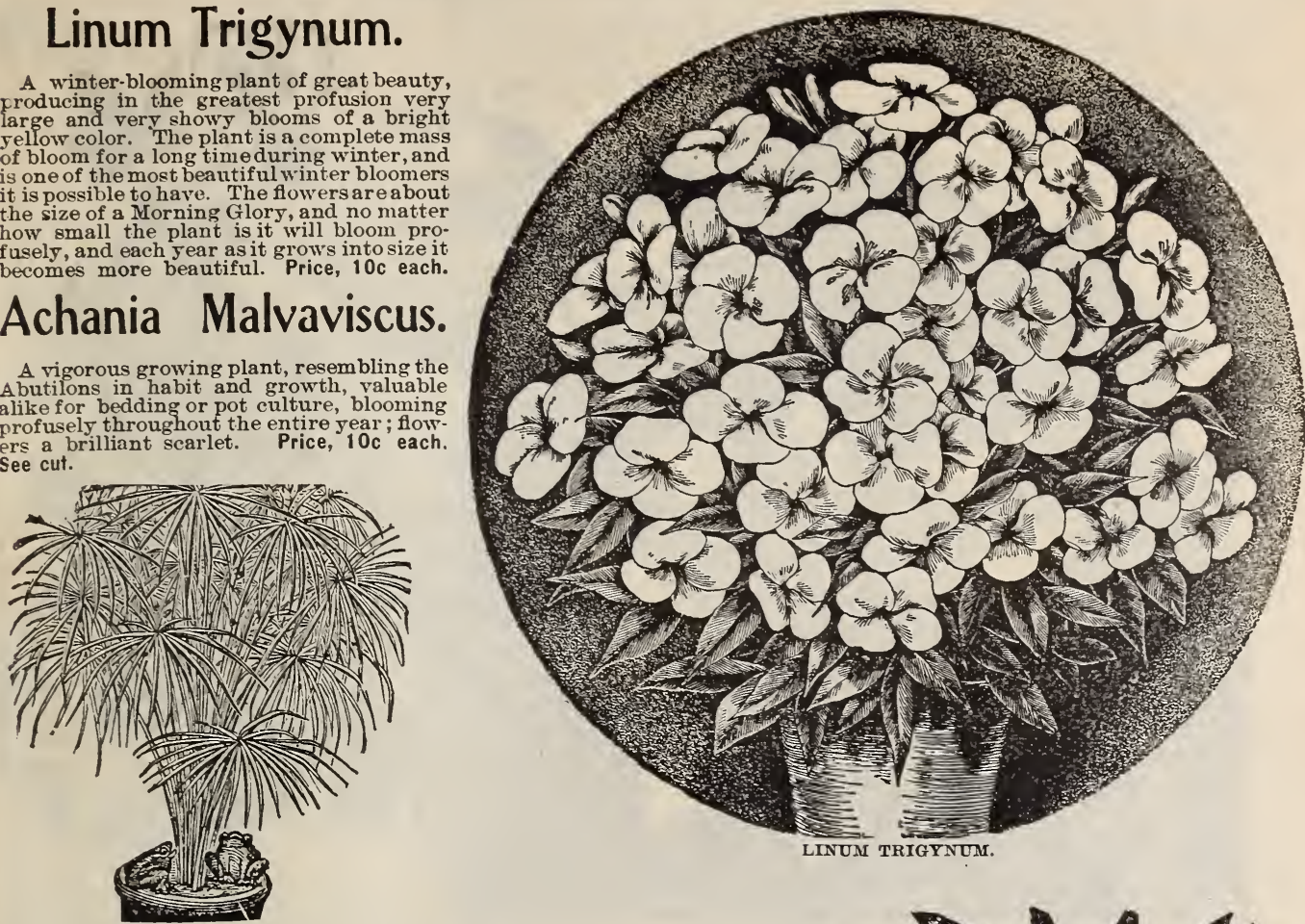

Umbrella Plant.

(Cyperus Alternifolius.)

An ornamental grass, throwing up stems about two feet high, surmounted at the top with a whorl of leaves, diverging horizontally, giving it a very curious appearance. Splendid for the center of vases or as a water plant. Price, $10 \mathrm{c}$ each; large, handsome plants $20 \mathrm{c}$ each.

THE BEAUTIFUL, HOUSE PLANT

\section{Sanseveria Zealanica.}

This beautiful house plant is well adapted for the decoration of sitting rooms, halls, etc., as it stands dust and neglect of watering

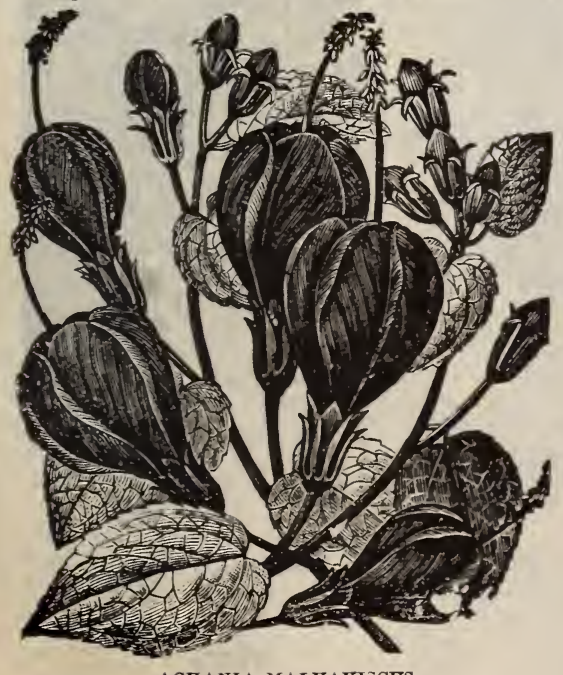

ACHANIA MALVAVISCU8. with impunity. The leaves, as shown in illustration, grow to a length of three to four feet, and are beautifuliv

broad, white variegations on a dark-green ground. It is a rareand beautiful plant, which should be abundantly grown for positions out of the reach of sunlight where other plants will not thrive. When you consider that it can be placed in any position in any room, usefulness is at once apparent. It has a singular beauty for decorative purposes, which other plants do not poscess, and is useful both winter and summer. The beautr of its leaves and the handsome spike of flowers it produces make it one of the most desirable plants known. Price. nice, strong plants, $15 \mathrm{c}$ each; extra large size. $25 \mathrm{c}$.

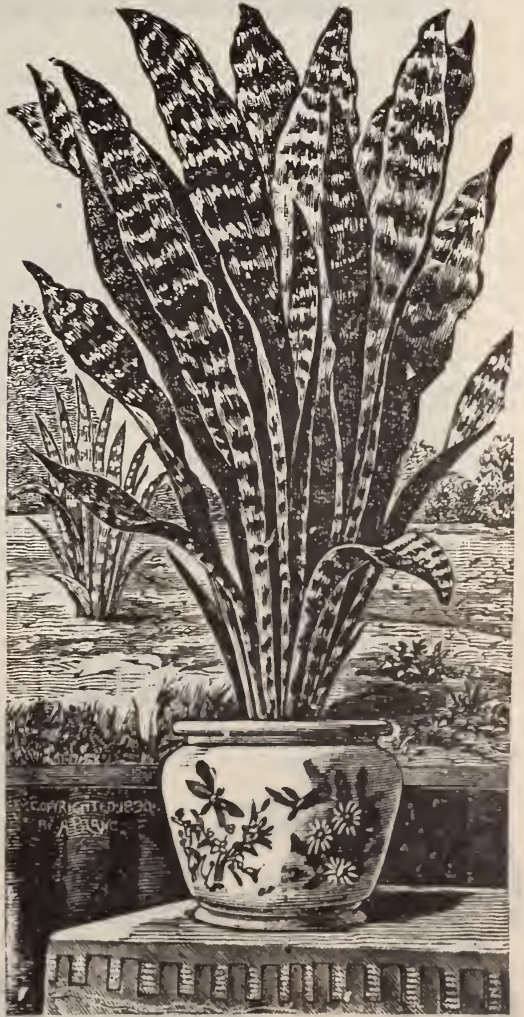

BANSEVERIA ZEALANICA. 


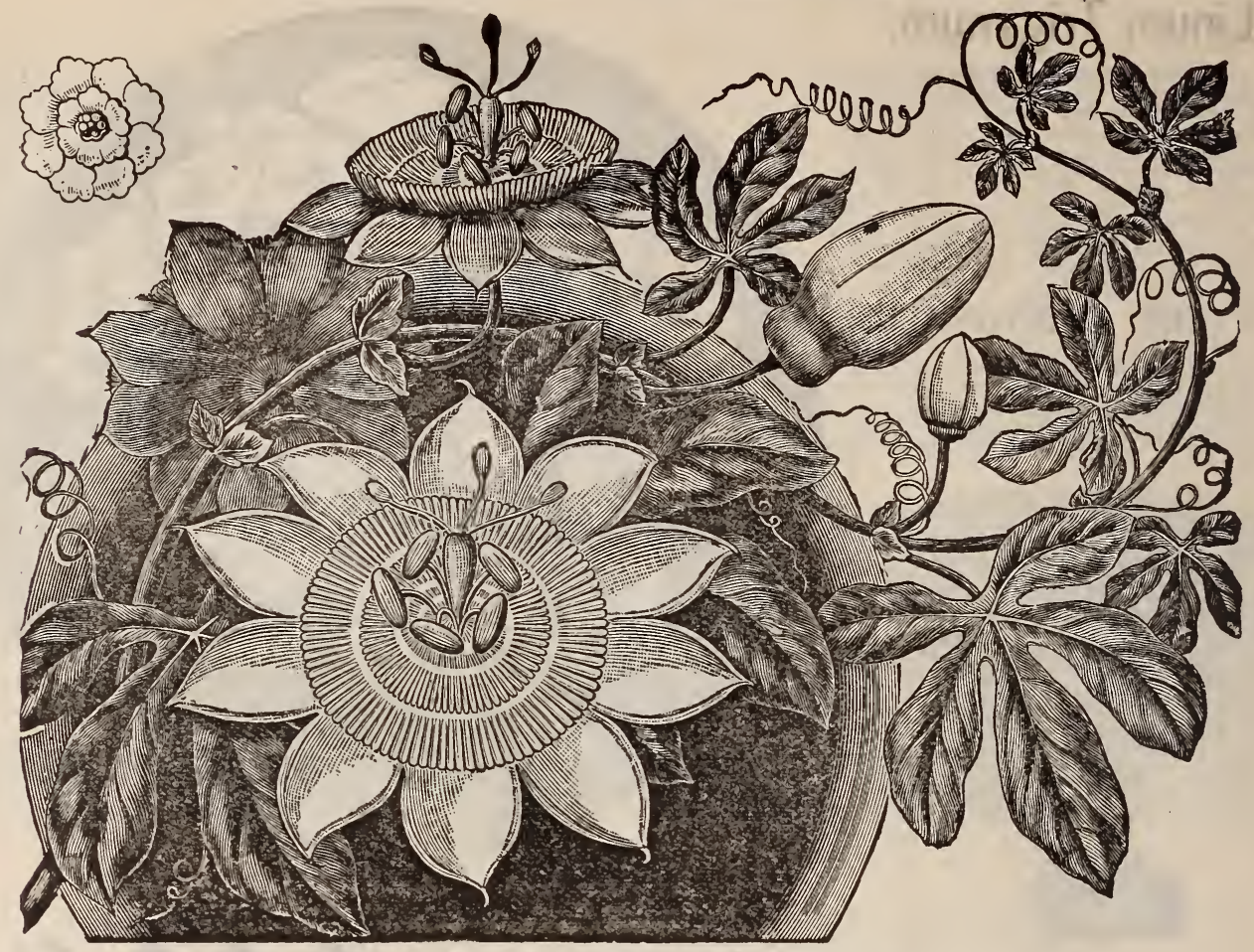

WHITE PASSION FLOWER, CONSTANCE ELLIOTT.

CONSTANCE ELLIOTT-New Hardy Passiflora.

This beautiful variety is hardy and free growing. As a hardy climbing plant it rivals some of the Clematis in size, color

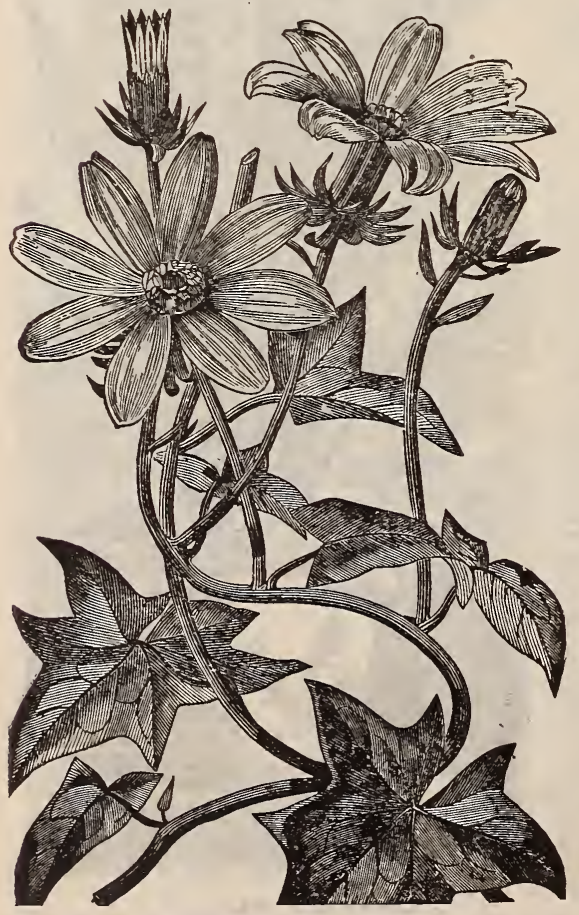

GERMAN OR PARLOR IVY. and bloom, and surpasses them in vigor of growth and delicious fra-
grance. The flowers are very large and are of pure ivory white. Excellent for cemetery purposes. Strong plants, $10 \mathrm{c} \mathrm{each}$; three for $25 \mathrm{c}$.

\section{GERMAN OR PARLOR IVY.}

A rapid growing and succulent plant, well adapted for covering trellis work quickly or training in the parlor. Leaves glossy green and flowers yellow, in cluster's. Price, $8 \mathrm{c}$ each; three for $20 \mathrm{c}$.

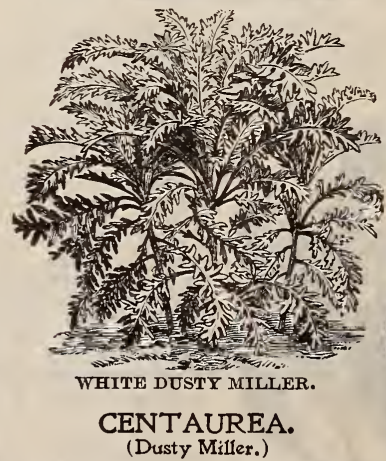

Gynmnocarpa-Attains a diameter of two feet, forming a graceful rounded bush of silvery gray, for which nothing is so well gray, for which nothing is so well to contrast in ribbon lines with a
dark foliage plant. Price, $8 \mathrm{c}$ each; 5 for 25 c.

GLECHOMA HEDERACEA

Variegated Ground Ivy. The foliage of this charming novelty is a bright green, marked with pure white, and has a refreshing fragrance similar to mint. Fine for hanging baskets and vases. Price, $10 \mathrm{c}$ each; thre? for $25 \mathrm{c}$.

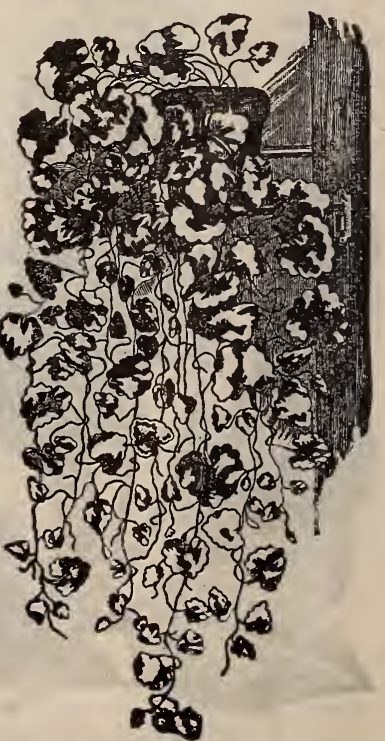

SILVER-LEA VED GROUND IVY. 


\section{Beautiful Fragrant Jasmines.}

SPECIAL OFFER: We will send the set of four Jasmines for only 30 cents.

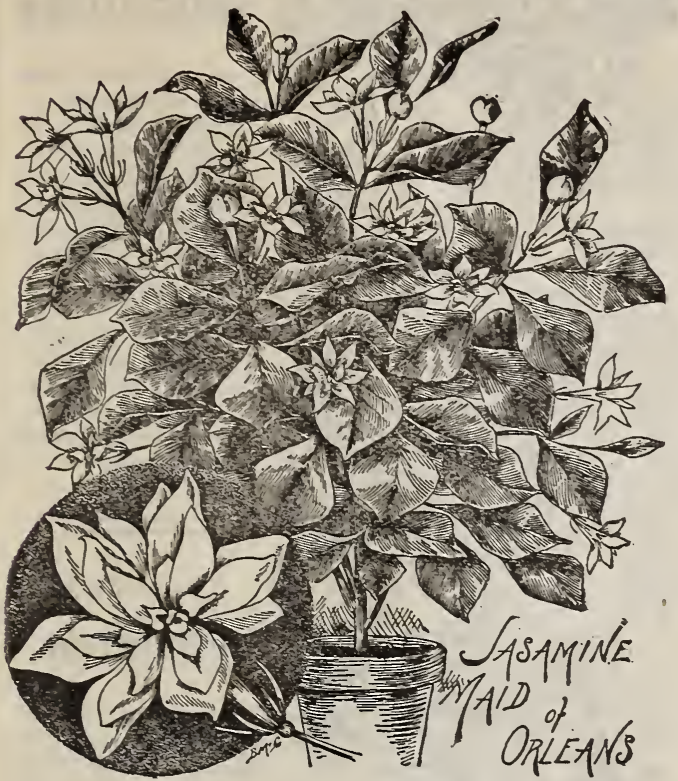

New Jasmine, Maid of Orleans-A very attractive new sort, with good sized double flowers, blooming profusel all Summer; shining, pale-green foliage. We predict for it a rapid sale, as it is so much easier to handle than other Cape Jasmines, and, on the whole, more desirable. Price, nice plants, $10 \mathrm{c}$ each; extra large plants, $25 \mathrm{c}$.

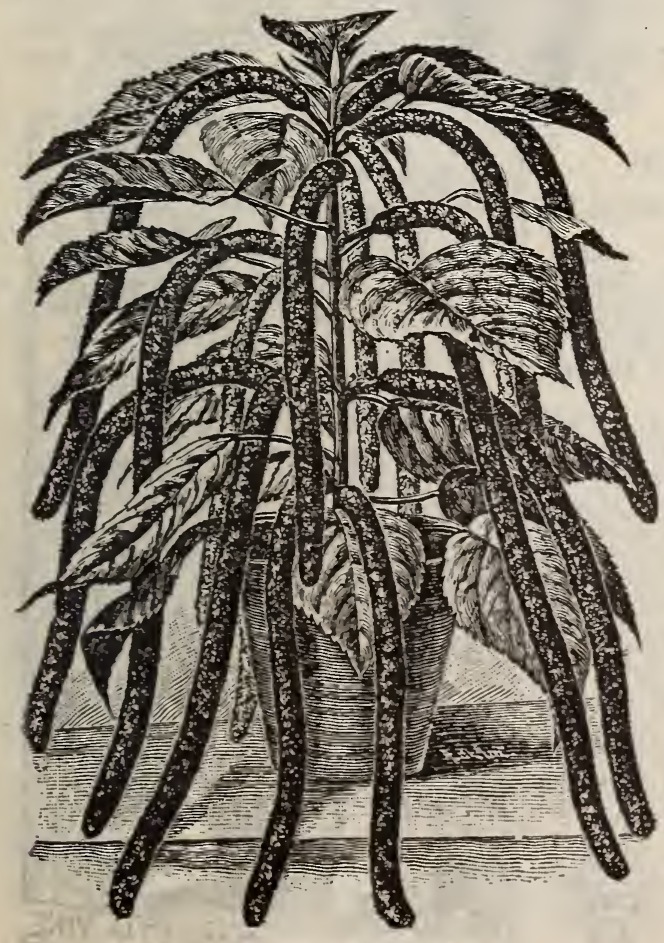

ACALPHA SANTERII.

Jasmine Grandiflorum-A beautiful plant, with small, glossy, evergreen foliage, handsomely arranged on long, graceful branches, which a re inclined to vine. It blooms in the Fall and Winter, bearing in the greatest profusion small, pure white flowers of a spicy fracrance which is trul delicious. A splendid house plant. Price, ioc each; large plants, $25 \mathrm{c}$ each.

The Yellow Jasmine-Almost erery one has either read or heard of the famous Southern Yellow Jasmine. Tourists go into ecstasies orer it and carefully press spray. of the exquisite blooms to carry to their Northern homes a mementoes of a Winter spent in "The Land of Flowers." There is not an easier grown or more beautiful climber in the window, succeeding in almost any situa foliat is quicie growing, suceeding vellow, crquisitely sweet-scented, funnel-shaped flowers. Price, 10c each; large size, $25 \mathrm{c}$ each.

Jasminum Gracillum-A new Jasmine and remarkable for its freedom of bloom. A flowering stem is produced from every joint, which terminates in a dense cluster of pure white, fragrant flowers. We have seen flowering branches
of this Jasmine two feet in length. A charming plant. Price, $10 \mathrm{c}$ each; large plants, $25 \mathrm{c}$ each.

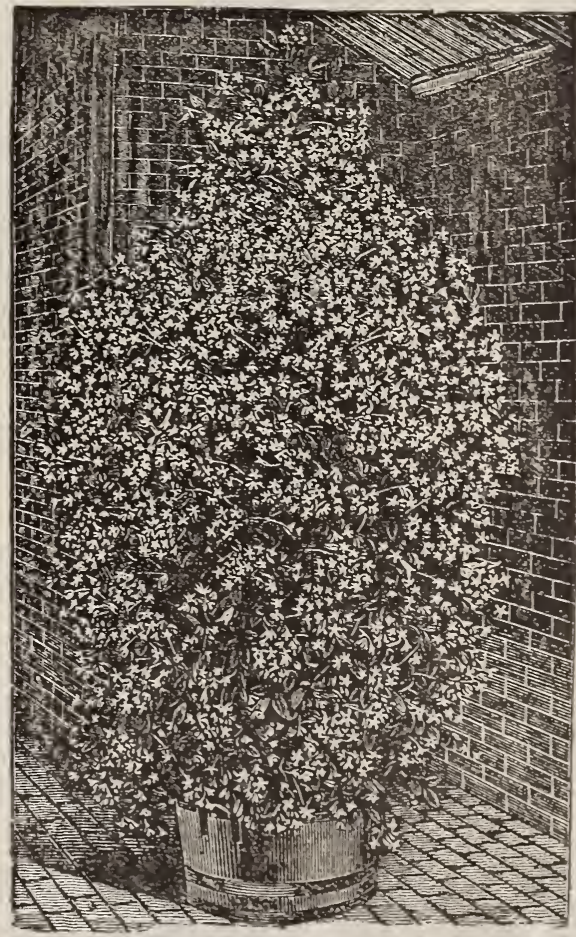

THE YELOW JASMIYE.

Handsome Acalpha Sanderii

This plant goes under various names, such as "Chenille Plant," "Philippine Medusa," "Comet Plant," "Dewey's Favorite Flower," "Bloody Cat Tail," etc. Without doubt the most sensational new plant introduced for many rears, and one of the most striking flowering ornamental plants we have erer seen. It is of strong, free growth, with large, dark green leaves. From each axil rope-like spikes of velvety crimson flowers are gracefully suspended, of from one to two feet long and nearly one inch thick, as shown in our illustrawarm when conveys but a fant acquicition. But the remarkable floriferousness and the great size of the spikes of flowers (compared to the plant) is fairly well shown. The plant is in flower the rear round, and is as easily grown as the Coleus, simply rrquiring a warm temnerature to develop its beaty. Fine plants, $10 \mathrm{c}$ each; three for $25 \mathrm{c}$. 
THE CHARMING EVER-BLOOMING .. IMPATIENS SULTANI..

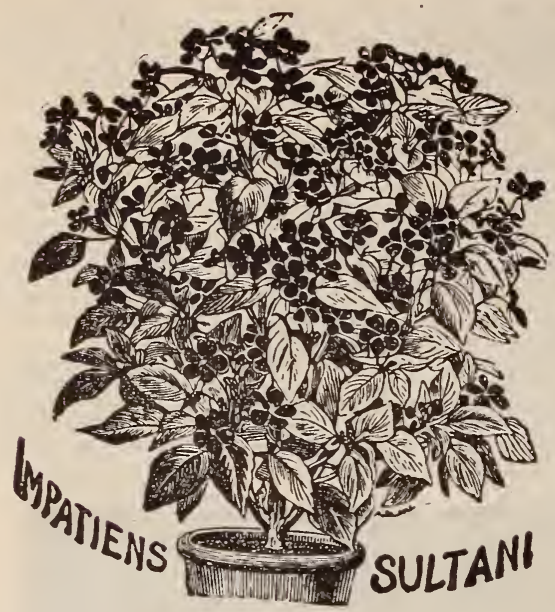

This is the most distinct and beautiful of all flowering plants of recent introduction, either as a Winter-blooming pot plant or for the border in the Summer. It is of compact. neat habit of growth, with good constitution and a perpetual loomer. Indeed, it is never without bloom. It will produce The flowers are of a brilliant, rosy-scarlet color, of peculiarly distinct, but most effective hue, and are produced singly or in twos and threes from the axils of the leaves, especially toward the summit of the stems, but so freely that a well-grown specimen appears to be quite a ball of fire.
recommend this highly. Price, $10 \mathrm{c}$ each; three for 25 cents.

\section{FEVERFEW-LITTLE GEM.}

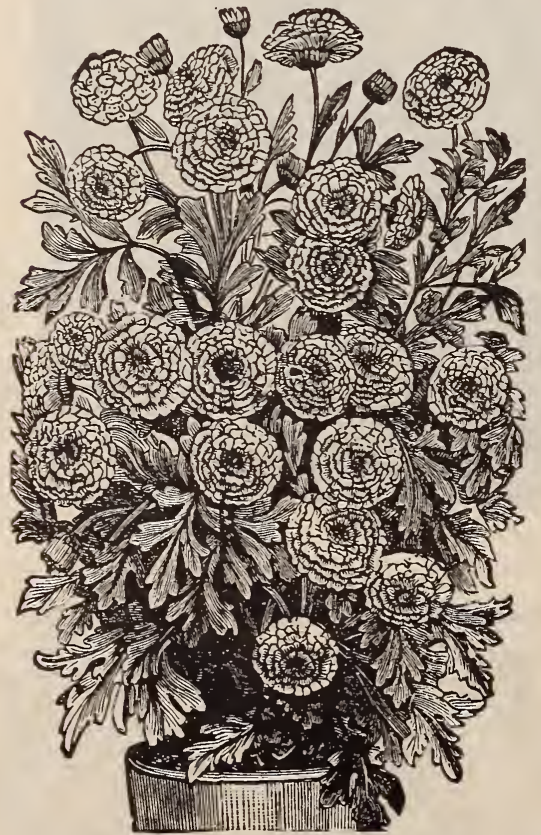

This sort is valued very highly, surpassing the old sort in every way. It is very dwarf, attaining a height of twelve inches. The flowers are large, of perfect form, and of the purest white. Splendid for cutting. Price, $8 \mathrm{c}$ each; three for 16 cents. each.

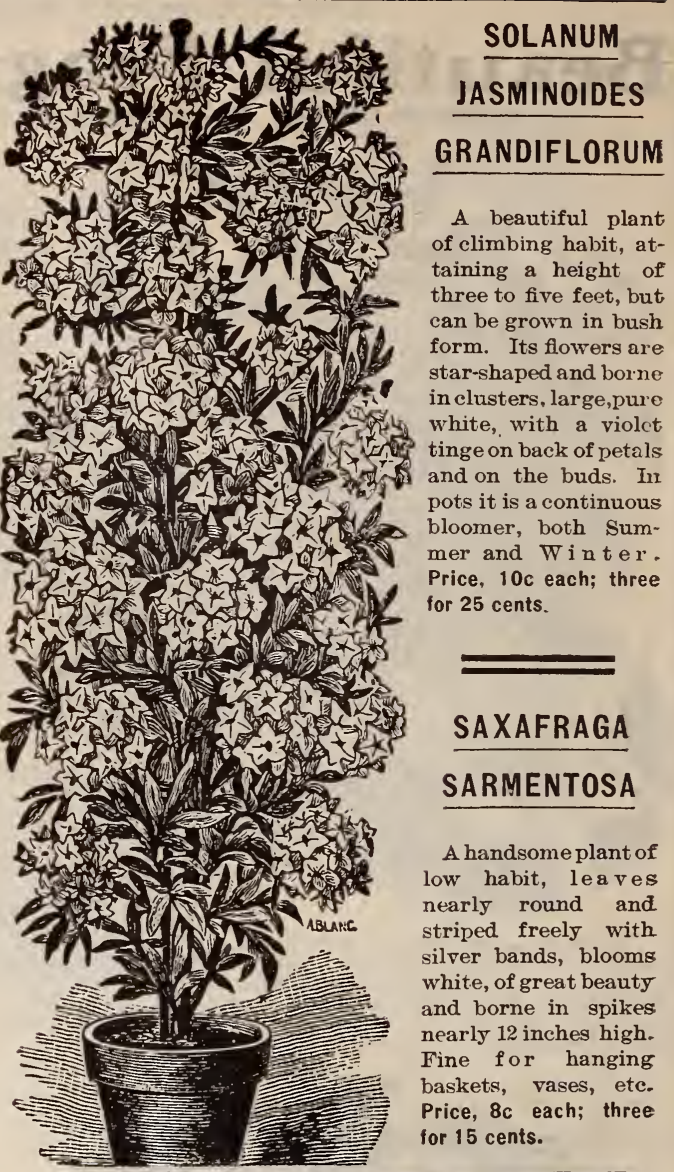

MANETTIA

BICOLOR

THE MOST WONDERFUL NEW VINE OR PLANT THAT HAS YET BEEN PRODUCED. IT BLOOMS IN WINTER AS WELL AS IN SUMMER.

It is both a rapid and beautiful climber. The flowers are from an inch to an inch and a half in length, of a most intense bright scarlet, shaded into flame, tipped with the deepest golden-yellow and covered with a thick scarlet moss. The blossoms remain on the petals for weeks before falling. has our highest commendation. Send to uin and get the gensend them in buany Price, fine plants, $10 \mathrm{c}$

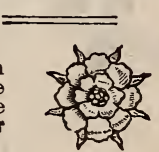

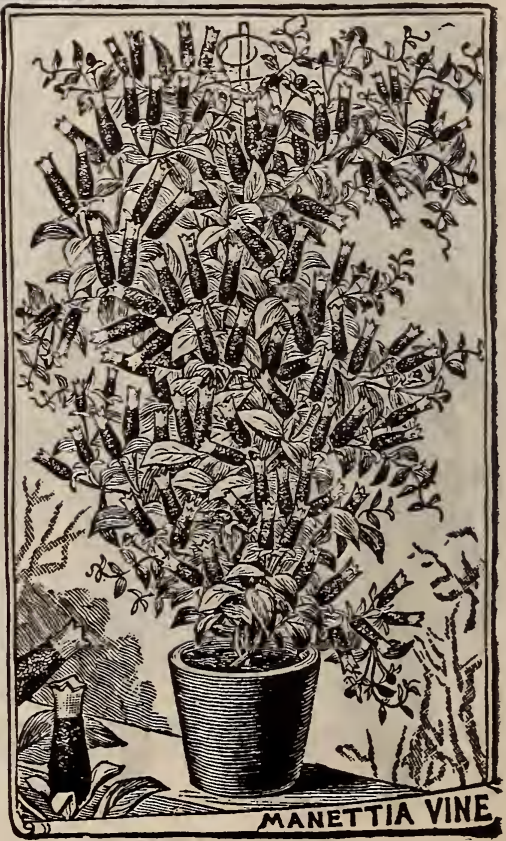


HARDY SCOTCH OR SWEET MAY

\section{P I N K S}

The set of five beautiful Hardy Pinks for on 1 y 25 cents.

These are the Pinks of our mother's gardens. They are dwarfer than the Carnation, growing about one foot in height, the colors being of the various shades of maroon, carmine, and rose, beautifully laced and banded on white ground. The flowers are perfectly double, clove-scented, and the plants will stand out of doors year after year, be ing entirely hardy. They malie a very nice border for beds of other flowers, or for cemetery planting, making a large tuft of bronzs-green foliage a foot or more in diameter, from which the flower stalks are thrown up in great profusion Gertrude- White, with maroon markings. Price, $8 \mathrm{c}$ each.

Brunette-Center very dark and Velrety, almost black. Tery fine. Price, $8 \mathrm{c}$ each.

Irary Gray-Reddish-purple, narrow lacing of white. Price, $8 \mathrm{c}$ each.

Ear1 of Carlisle-Tarious shades, maroon and rose, with white. Price, $8 c$ each.

The New Double White Pink, Her Majesty-We have much pleasure in drawing attention to this charming novelty, which is unquestionably one of the finest of the century, and one that will hold its own as long as Pinks are cultivated. It has become one of the most "popular of the day," and is being grown by acres to sup
the demand for cut flowers. Price, 10c each.

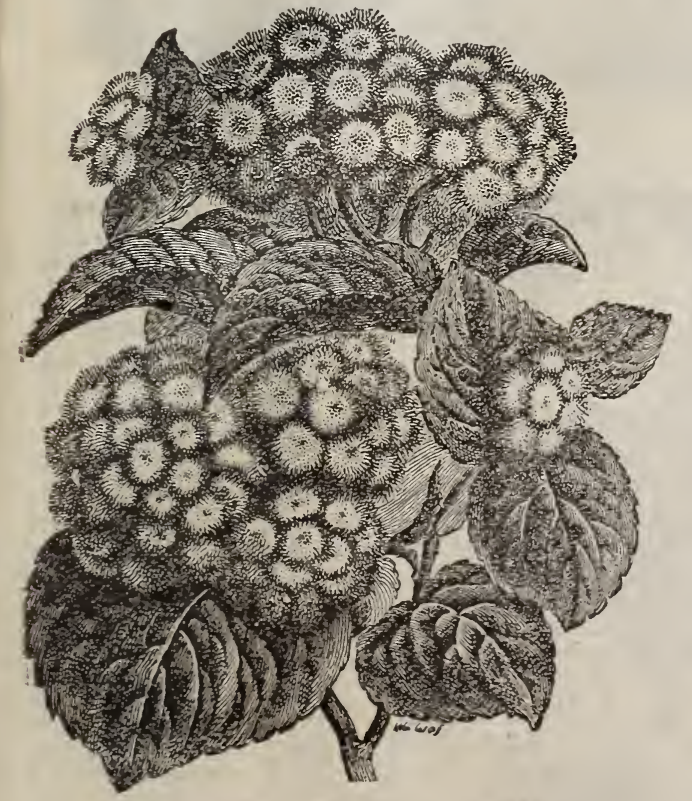

NEW AGERATUM, PRINCESS PAULTNE.

\section{Weeping Lantana}

This plant has a most graceful, drouping habit, grow's very rapidly and blonins continually summer and $\mathbf{W}$ intei, producing large clusters of flowers of the inost delicate lilac or rosy pink; foliage a beautiful dark green. Price, 8 c. each.

\section{New Variegated Ageratum PRINCESS PAULINE}

A novel and distinct variety of dwarf, compact liabit, rarely exceeding six inches in height, its peculiarity bein flower theolors, blue and white, are comble while the stamens are a light sky blue, giving the whole flower a pleasing varie gated appearance, and making it one of the most distinct new bedding plants. Price, $8 \mathrm{c}$ each.

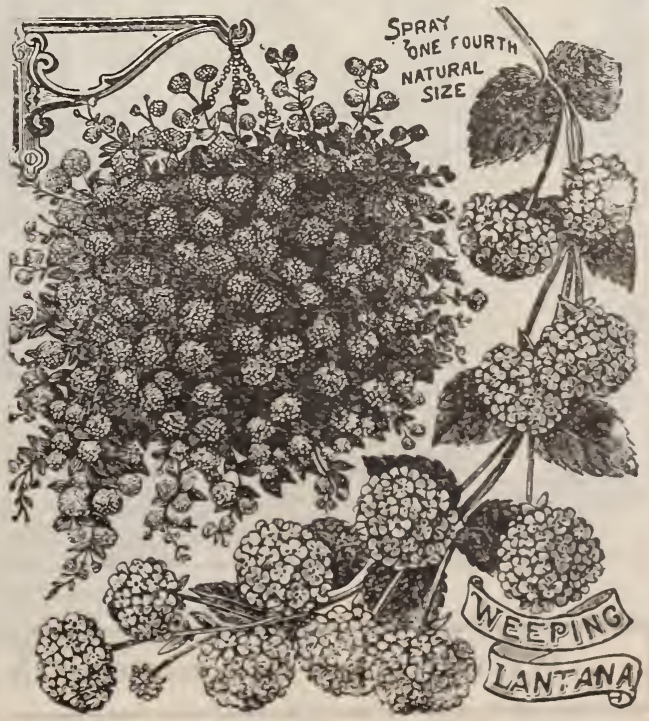




\section{SWEET VIOLETS}

\section{VIOLET BABY}

\section{BLUE.}

New. This is by far the best blue Violet grown, deliciously fragrant and very prolific. The color is a delicate blue, hence its name "Baby Blue." The growth of the plant is vigorous and healthy. Valuable either in pots or planted out. A charming contrast with the white variety, Swanley White. Price, $10 \mathrm{c}$ each.

New Giant-Flowered Violet,

\section{CALIFORNIA.}

The plant is a robust grower with dense, heary foliage, entire ly free from the disease that is so destructive to the older sorts. Flowers single, intensely fragrant. Color, a clear, violet purple that does not fade. The flowers are very large and borne on stems ten to twelve inches long. giving them unusual value for cut-flowers. Try one. Price, 10c each.
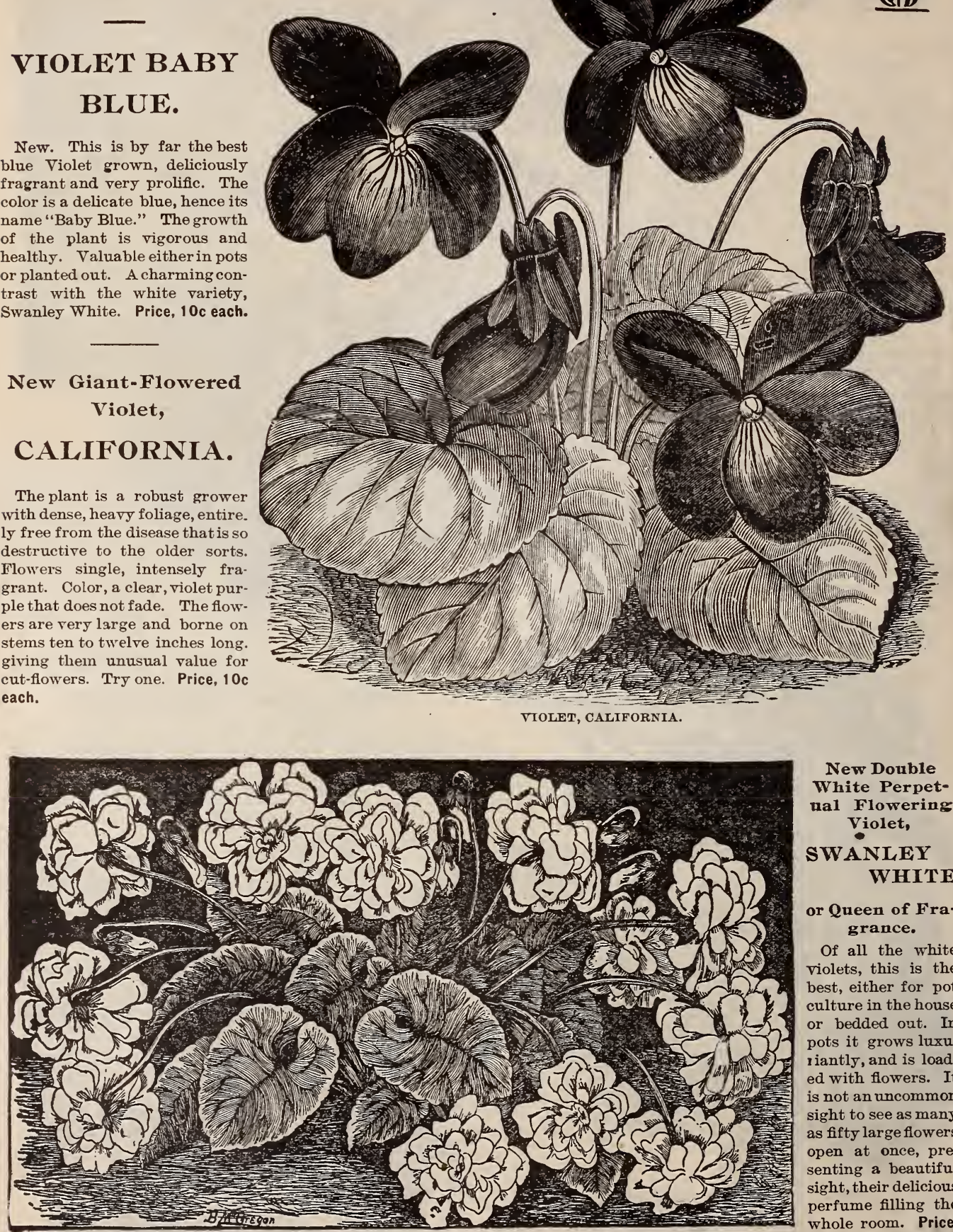

New Double White Perpetnal Flowering Violet,

SWANLEY WHITE or Queen of Fragrance.

Of all the white violets, this is the best, either for pot culture in the house or bedded out. In pots it grows luxuriantly, and is loaded with flowers. It is not an uncommon sight to see as many as fifty large flowers open at once, presenting a beautiful sight, their delicious perfume filling the whole room. Price, VIOLET, SWANLEY WHITE. $10 \mathrm{c}$ each.

We will send one each of these New Violets for 25 cents. 


\section{THE TRUE BLUE AND WHITE * * \\ * MOON FLOWERS}

These handsome Climbers reach the height of 25 feet in a very short time, are profuse bloomers and delightfully fragrant. $* *$

The Blue Moon Flower, I pomoea Learii-From Ceylon. A handsome, quick-growing, perennial climber. It often flowers in bunches of a half dozen. The flowers are trumpet-shaped, about four inches across, of a rich violet blue, with five purple rays, grows about 25 feet in one season, and is a most attractive climber. Price, $10 \mathrm{c}$ each; 3 for $25 \mathrm{c}$.

True Moon Flower, Ipomoea Grandiflora-This plant has become very popular, and it certainly is a wonderful annual climber It grows rapidly and blooms profusely. Flowers five inches in diam: eter and quite fragrant. A very rapid Summer climber, blooming the first season. No insects attack the leaf, and even if it did not bloom it would be very desirable because of the beauty of its foliage. But when is added to this the wonderful effect of its flowers, which are borne in great profusion, it cannot fail to please. The flowers are im-

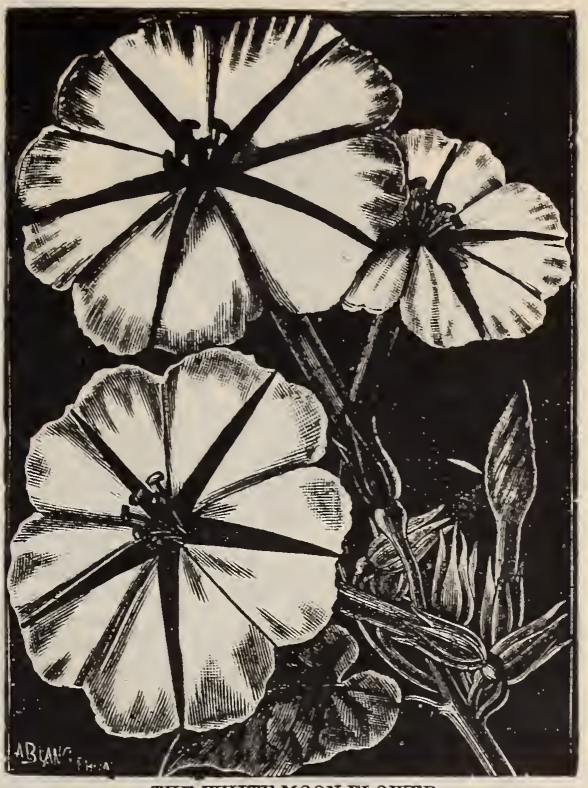

THE WHITE MOON FLOWER. mense, pure white, sweet-scented, flve inches in diameter, boine very profusely, and, as they open at night, are very striking. Being a free bloomer, the effect on a moonlight night is charming. It is a splendid plant for verandas. Price $10 \mathrm{c}$ each; 3 for $25 \mathrm{c}$.

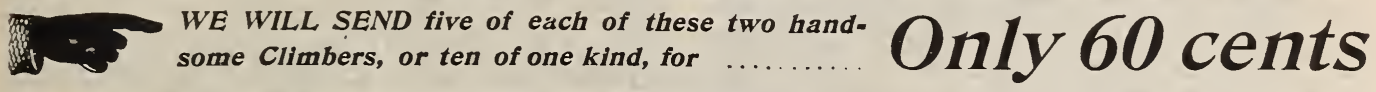

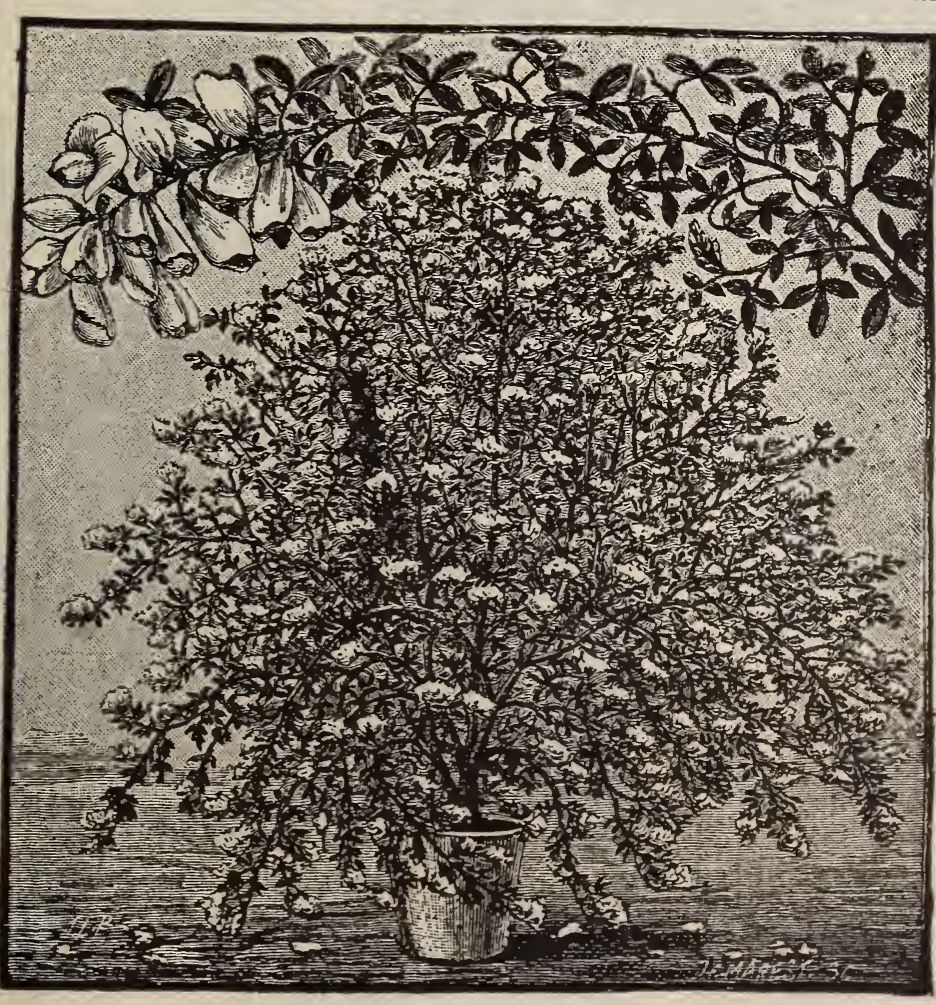

FOUNTAIN OF GOLD.

\section{GENISTA}

\section{CANARIENSIS.}

Fountain of Gold - The drooping branches are covered with delicate sage-green foliage, and every twig tipped with a long raceme of exquisite peashaped blossoms of a pure canary color, almost hiding the foliage. and suggesting the name, "Fountain of Gold." Nice strong plants. Price, $10 \mathrm{c}$ each; three for
25c.

$$
* * *
$$

\section{THE LOVELY BLUE}

\section{ERANTHEMUIM}

A splendid Winter-blooming plant. Flowers of a rich, deep blue color. Price, 10 cents each; three for 25 cents.

\section{$* * *$

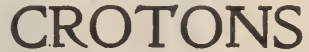

The Crotons are among the finest decorative foliage plants known. Leares are more or less entirely variegated with shades of yellow, orange and crimson. Some have long, narrow leaves, fashion, others broad and shortoakleaved. Some recurved very much, others twisted, corkscrew like. Crotons love heat, sunshine and moisture. Price, nice plants $15 \mathrm{c}$ each; three distinct sorts for 30 cents. 


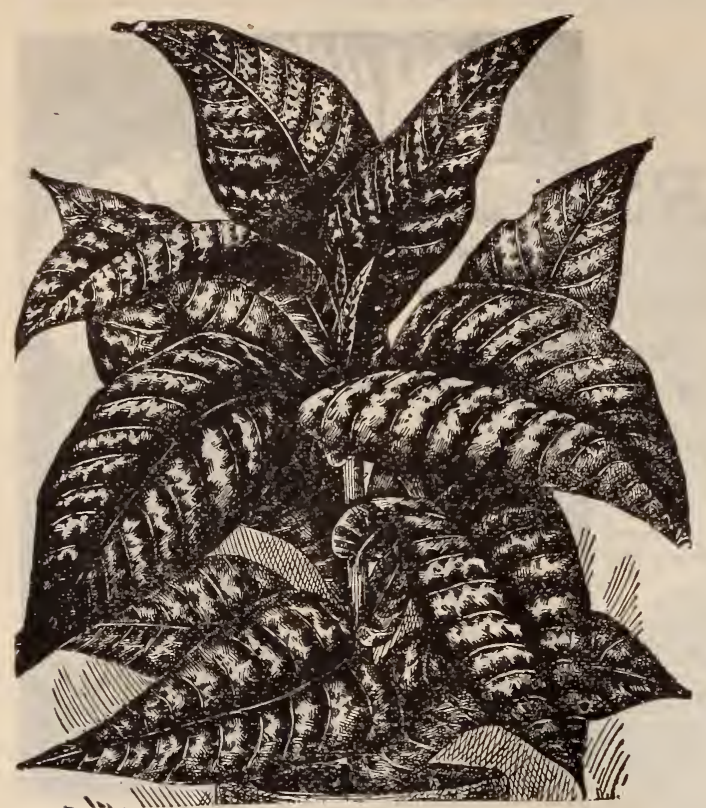

ROYALPURPLE

Strobilanthes Dyerianus-A new and very beautiful folistrobint from Singersally follage plant from sing porelliant and exquisite coloring of its leaves, the beauty of its flowers and in its extraordinarily easy growth and usefulness as a decorative plant. It surpasses the finest Coleus in exquisite coloring of the leaves, which the plant is eovered in mid-winter greatly enhance its value and beauty. Price, $10 \mathrm{c}$ each; three for $25 \mathrm{c}$.

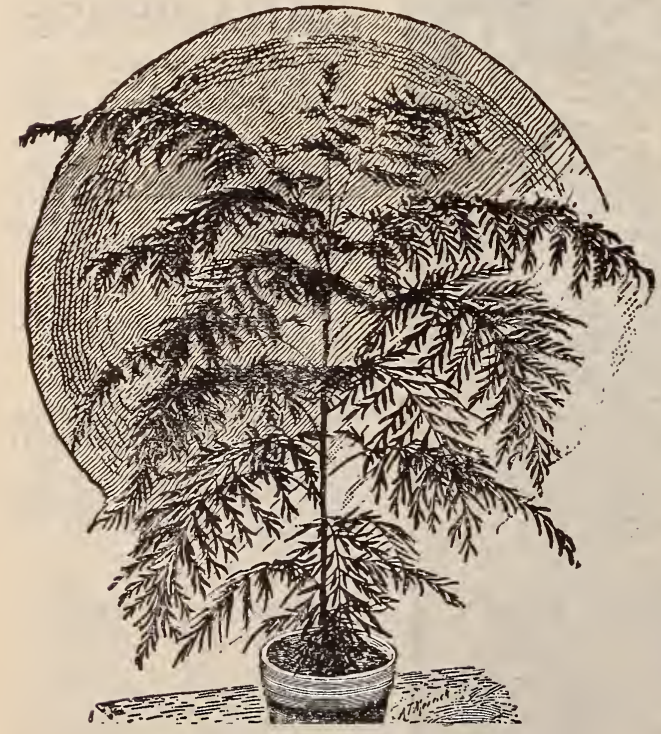

GREVILLEA ROBUSTA

The Silk Oak-A magnificent plant for decorative purposes, of rapid, easy growth, finely cut foliage, rivaling a rare Fern. The young growing leaves are a light bronze color, the tips being covered with a soft down, closely resembling raw silk, hence the name of "Silk Oak." In its native place it attains magnificent proportions and produces an abundance of bright, orange-colored flowers. Price, fine plants, $8 \mathrm{c}$ each: extra large plants, $15 \mathrm{c}$ each.

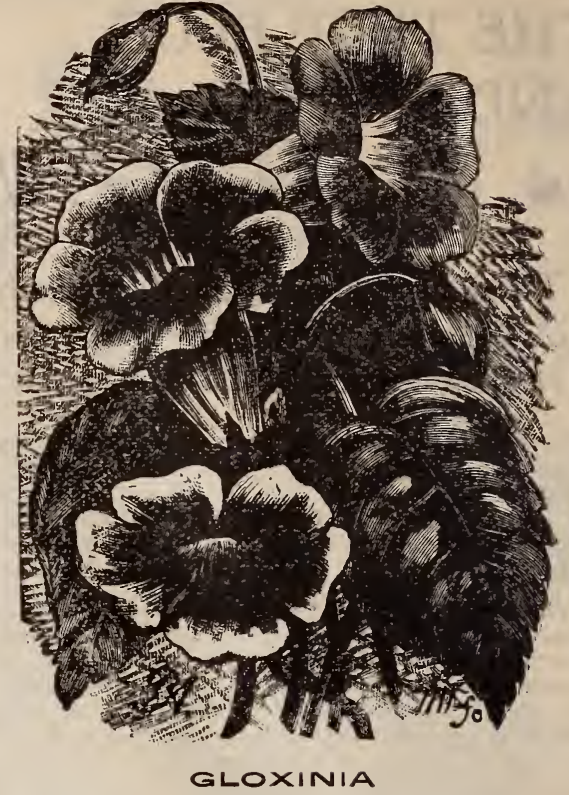

The coloring is exquisite; the ground of many is pure white, with throats of blue, scarlet, rose, crimson, or velvetypurple; or the tubes are of bright color, with white throat. The bulbs should be started in a warm place, and kept growing in a partial shaded place, protected from hard rains. They will bloom until late in Summer, when they should be dried off, letting the leaves die, and can be kept over Winter in a cellar free from frost. Dry bulbs, price, $15 \mathrm{c}$ each; three for 30c.

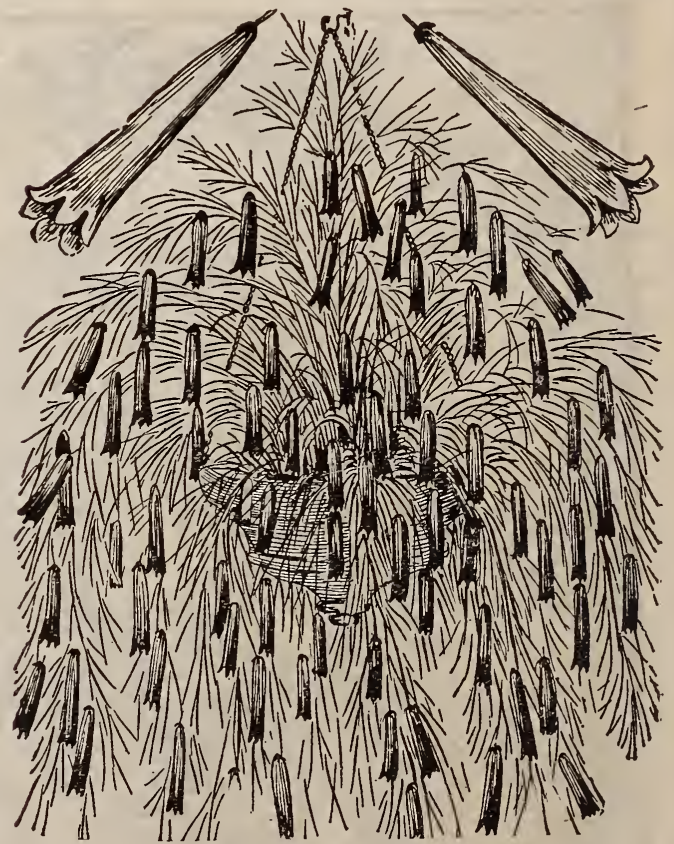

RUSSELIA JUNCEA

A charming basket or vase plant, suitable either for garden or pot culture and requiring the same treatment as a Geranium. The flowers are about the size of a Mannettia, long, trumpet-shaped and brilliant scarlet in color. It is one: of the easiest of all plants to grow, and is particularly valuable for baskets. Price, $8 \mathrm{c}$ each; three for $25 \mathrm{c}$. 


\section{LANTANAS}

YELLOW, WHITE, PINK AND VARIEGATED

They are Very Fine for Bedding.

New Lantana, Dixie-A lovely new variety with large red and yellow flower and beautiful yellow foliage. A very strong grower and a mass of bloom all summer. Price, 10c each. (See cut.)

Comtesse de Biencourt-F l o w ers bright rose and yellow, center suphur dwarf and bushy. $10 \mathrm{c}$ each.

Nichael Schmidt-Flowers fresh and sparkling, of brilliant yellow, passing into purple vermilion. $10 \mathrm{c}$ each,

Jaroli-The finest pure white jet introduced; florets large,

La Pleur d'Or-Pure yellow flowers, very dwarf and bushy, very abundant bloomer. 10 each.

\section{ABUTILONS}

Or Flowering Maple

Price, 8 Cents Each.

Rapid growing plants of easy culture Flowers pendulous, bell-shaped and produced in great abundance. If taken up carefully before frost they mak

Arthur Belsham-C ol or clear, even crimson, without markings. An excellent variety of shrubby habit and great freedom of bloom.

Robert George-Free and continuous bloomer. The flowers are broad, their large, overlapping petals incurved; color orange, veined with crimson.

\section{.}

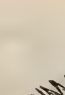

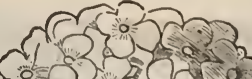

SPECIAL OFFER We will send these five best Lantanas for only 30 cents.

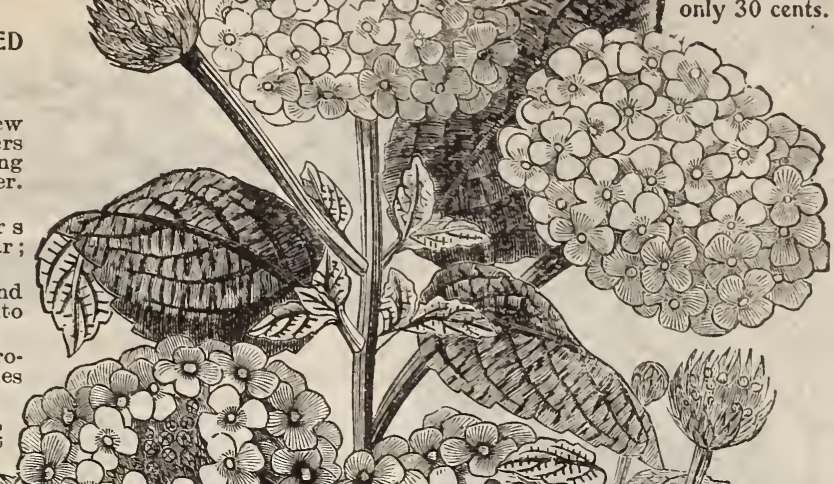

20 .
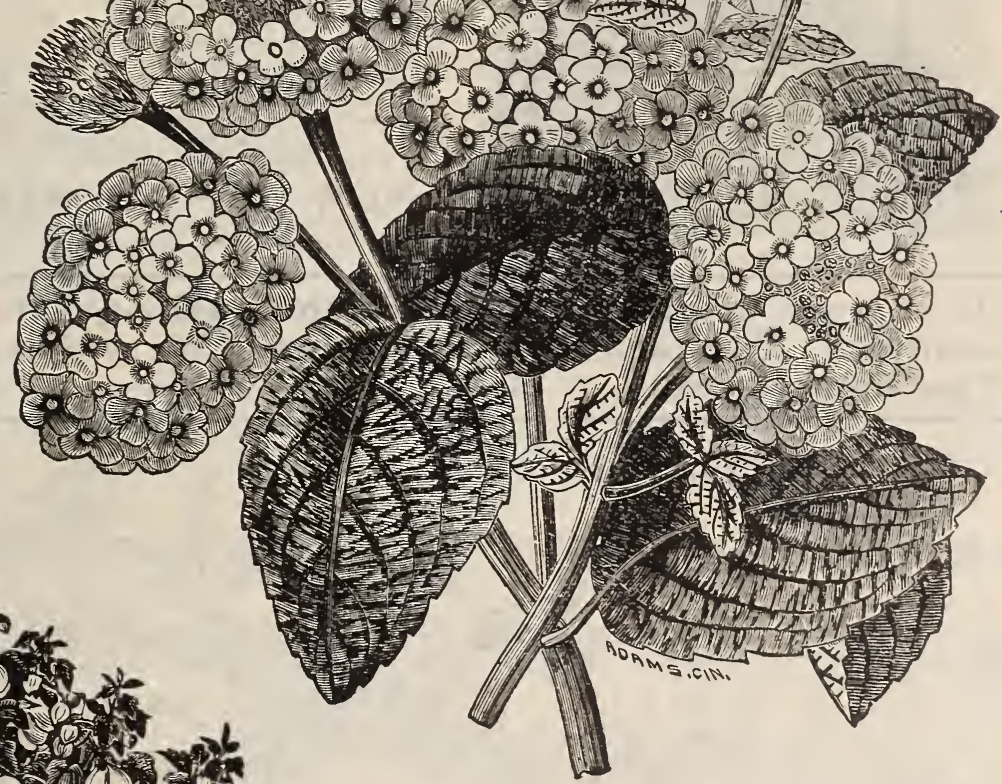

NEW GOLDEN LEAF LANTANA, DIXIE.

Golden Bells-A bright golden-yellow Abutilon, of strong, vigorous habit and very free flowering. There have been a number of yellow Abutilions introduced during the past few years. but they all lacked richness of color. The variety now offered combines large size, fine form and depth of coloring. Price, 10c

Souv. de Bonn-This is entirely different from anything we have had before in the way of variegated Abutilions. It is a strong, upright grower, with large, bright green foliage distinctly edged with a broad band of creamy white and yellow.
Flowers very large, on stems 8 to 9 inches in length. Colors, bright orange-red; very effective with its beautifully variegated foliage.

Thompsonii Plena-Beautiful variegated foliage, green and gold; has perfectly double flowers, resembling a double Hollyhock pendant; color, rich orange, shaded with crimson.

Eclipse-A very pretty trailing variety, with large foliage beautifulls marked with deep g-een and yellow. Flowers bright yellow with crimson throat; fine for vases or large hanging

Prince of Heilbron-Beautiful variegated foliage of bright green and gold; flowers light yellow, veined crimson.

Royal Scarlet-Brilliant scarlet, dwarf.

\section{SPECIAL OFFER}

GOLDEN BELLS.

We will send the entire set of eight Abutilens for 50 cents. 

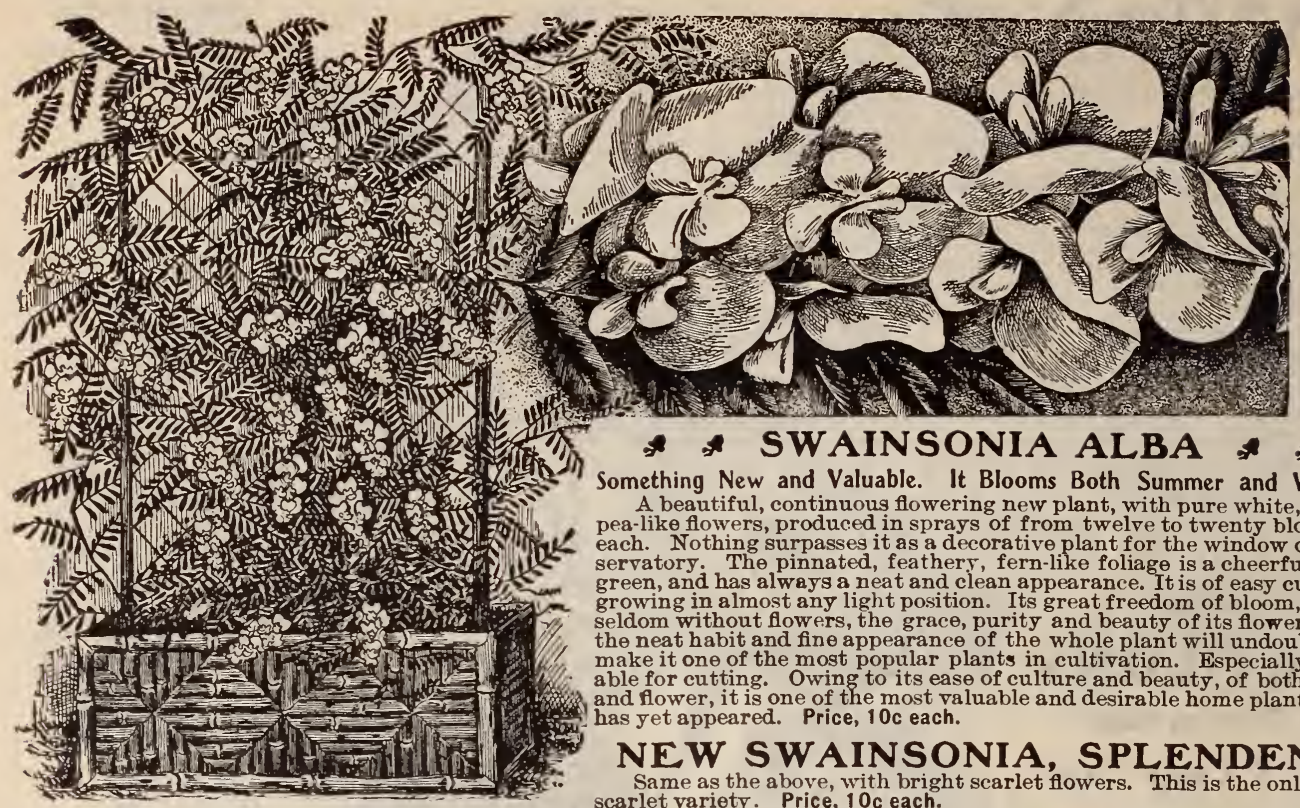

* SWAINSONIA ALBA * *

Something New and Valuable. It Blooms Both Summer and Winter. A beautiful, continuous flowering new plant, with pure white, sweet pea-like flowers, produced in sprays of from twelve to twenty blossom each. Nothing surpasses it as a decorative plant for the window or conservatory. The pinnated, feathery, fern-like foliage is a cheerful light green, and has always a neat and clean appearance. It is of easy culture, growing in almost any light position. Its great freedom of bloom, being seldom without flowers, the grace, purity and beauty of its flowers, an make it one of the most popular plants in cultivation. Especially valuable for cutting. Owing to its ease of culture and beauty, of both plant and flower, it is one of the most valuable and desirable home plants that has yet appeared. Price, $10 \mathrm{c}$ each.

NEW SWAINSONIA, SPLENDENS

Same as the above, with bright scarlet flowers. This is the only true scarlet variety. Price, $10 \mathrm{c}$ each.

These two Swainsonias are of the easiest culture and are very beautiful. They are always in bloom. We will send a strong plant of each for 15 cents. $\varnothing \varnothing \varnothing \varnothing \varnothing \varnothing \varnothing \varnothing \varnothing \varnothing \varnothing \varnothing \varnothing$

\section{THE BEAUTIFUL \\ MEXICAN}

\section{P RIMROSE.}

A charming basket or pot plant. Flowers of a beautiful bright, clear pink color, veied center. The superb color, combined with airy grace and beauwhich is in beauty perfection itself. The plant seldom grows inclines to a trailing habit, the ground or drooping over the $6 \mathrm{c}$ each; three for $15 \mathrm{c}$.

Hellanthus

Multiflorus

The

Double Golden SUNF LOWER

A double perennial "Sunflower." It is a great addition to our hardy plants. Its dark, golden-yellow color is both fash(ant flowers, and planted singly or in clumps on the lawn it gives a splendid effect. The plant grows about three or four feet high, bearing numerous large golden heads of flowers as large as Dahlias and continuing in bloom until frost, and will be much prized as corsage flowers. Price, $10 \mathrm{c}$ each; three for $25 \mathrm{c}$.

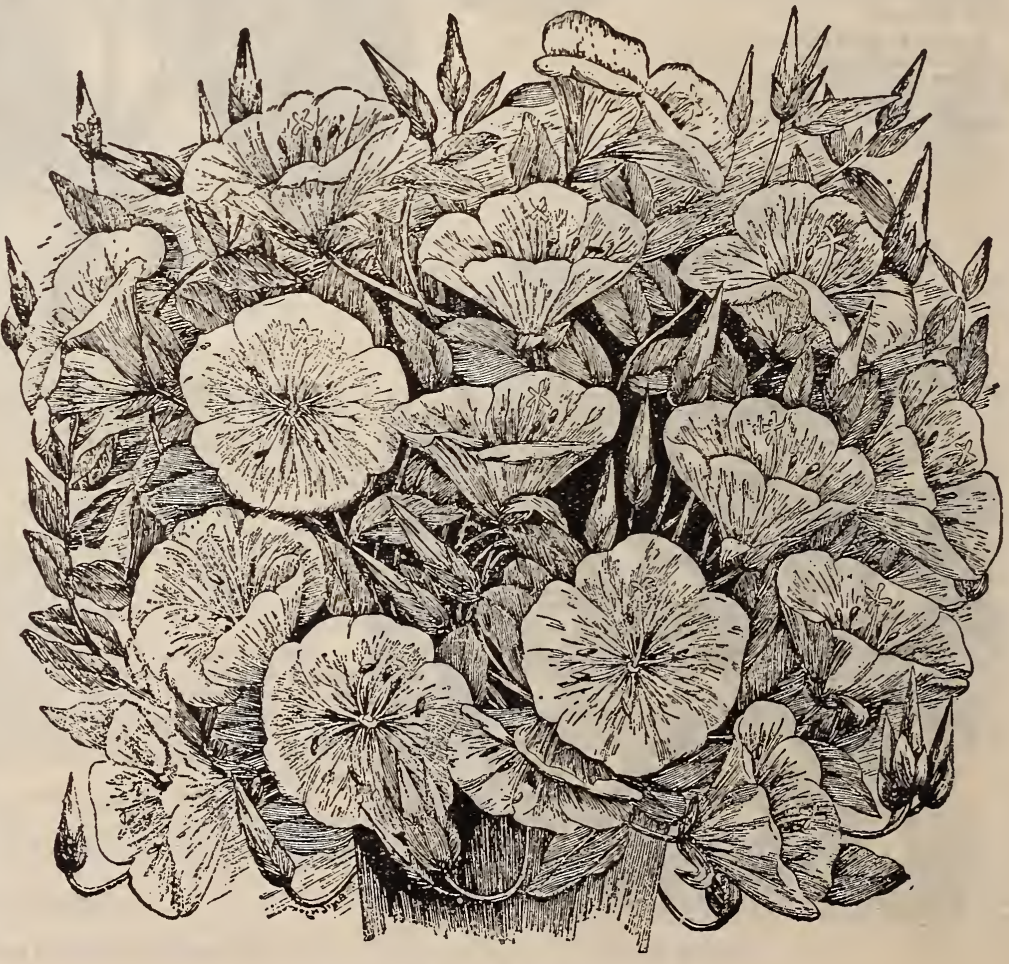

EVER BI.OOMTNG MEXICAN PRIMROSE. 


\section{CALLA LILIES \\ BLACK, WHITE...... \\ ......AND SPOTTED}

SPECIAL OFFER-We will send one each of the four Calla Lilies in

largest size for only $\$ 1.00$. The four in smaller size for 50 cents.

THE MAMMOTH BLACK CALLA, THE GREAT DRAGON ARUM.

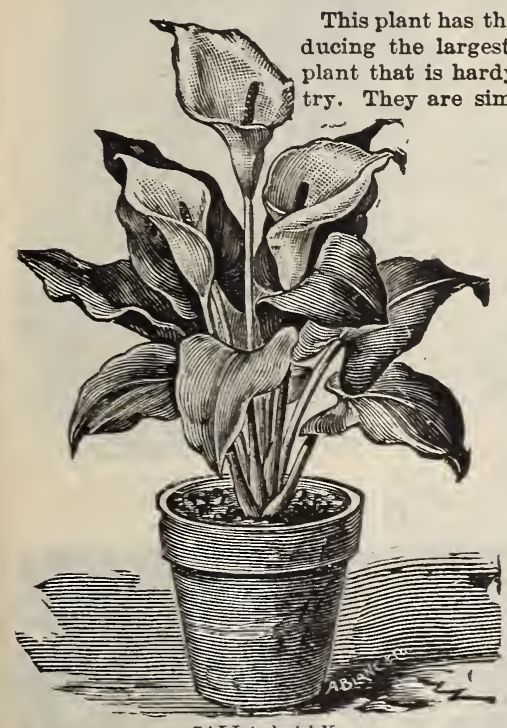

honor of pro ly enormous. The leaf stems and flower stalk are all spotted; upon the top of the latter opens a flower of $\mathrm{gigantic}$ size and curious color. On the outside it is of a light while the inside is of a deep red purple, glistening beautifully in the sun with The spadix in the center of the flower is of a glossy purple - black color. Price, each.

CAIUA LILLY

\section{GALLA ETHIOPIGA}

\section{Egypt/an L/Iy}

This is the well-known Egyptian Lily, or Lily of the Nile, with large white flowers, broad foliage, and it will prospe under very adverse circumstances. If you want large Callas send to us, as we are head-quarters for them. We have three sizes: Small plants to bloom next winter, $10 \mathrm{c}$ each; strong blooming bulbs, $25 \mathrm{c}$ each; extra strong bulbs that will produce a half dozen of blooms, $50 \mathrm{c}$ each.

\section{New Dwarf Ever-Bloom/ng Calla LIIy, TOM THUMB, or the Gem,} The Most Wonderful of all Plants.

"The Little Gem." The greatest value of this over the common Calla Lily lies in its dwarf habit and freedom of bloom. It rarely exceeds 12 inches in height and blooms most abundantly. The flowers are not more than half the size of the common variety, and therefore can be used with telling effect in boquets. It is in every way superior as a house plant to the larger growing varieties. Price, nice blooming plants, $15 \mathrm{c}$ each; extra large size, 25c each.

\section{calla righarda}

\section{Spotted Calla.}

The Richardia Alba, or Spotted Calla is a plant of magnificent appearance. The lea ves are of the richest green, spotted with pure white. The flowers are white, with a rich chocolate throat. It can either be grown in a pot, planted in a border, or in a vase or rustic stand, the latter being a very effective way of showing its beauty. Price, 15c each; very large bulbs, $25 \mathrm{c}$ each.

Callas delight in a light, rich soil and require plenty of water after growth has commenced. Give them plenty of light and air.
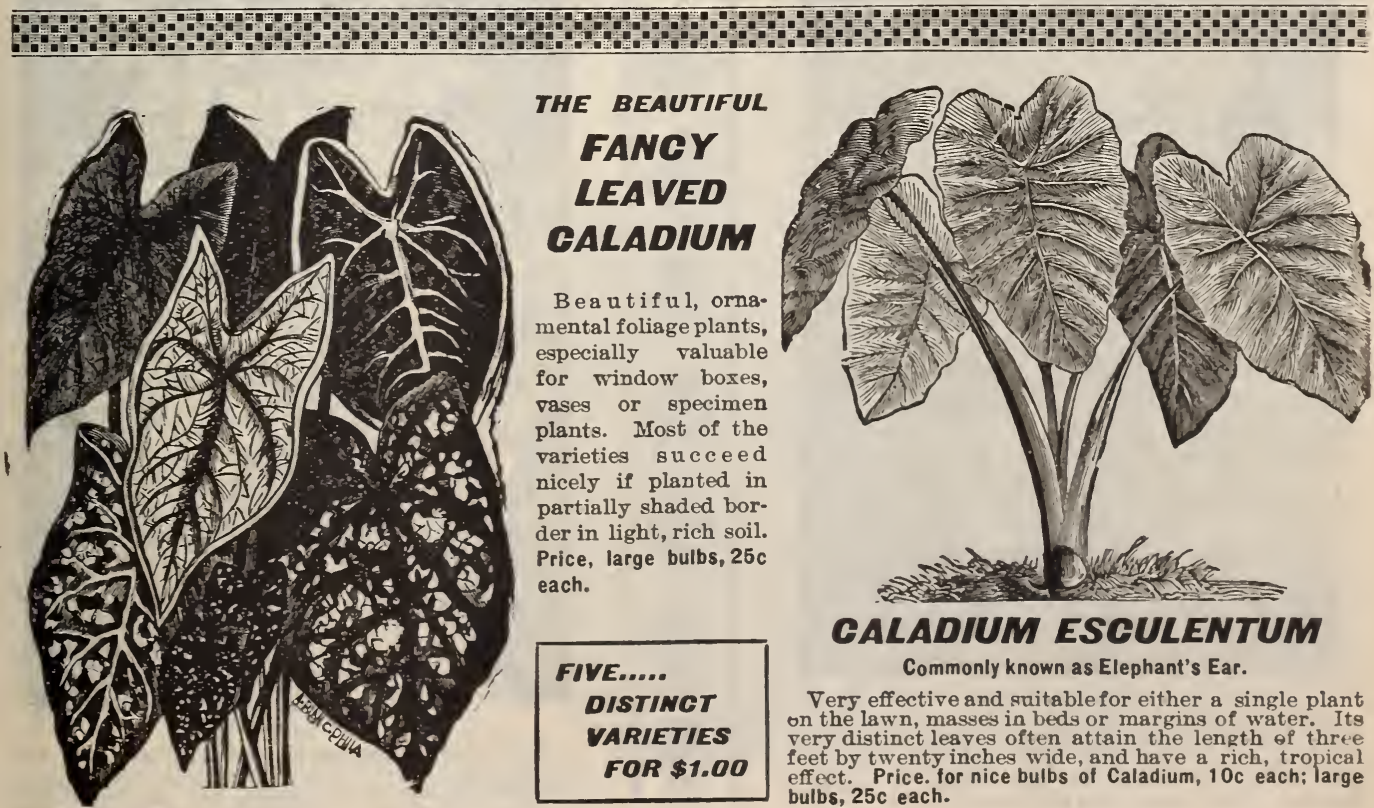

THE BEAUTIFUL

\section{FANOY \\ LEA VED GALADIUM}

B e a u if u l, orna. mental foliage plants, especially valuable for window boxes, vases or specimen plants. Most of the varieties succeed nicely if planted in partially shaded border in light, rich soil. Price, large bulbs, 25c each.

\section{FIVE..... DISTINCT VARIETIES FOR $\$ 1.00$}

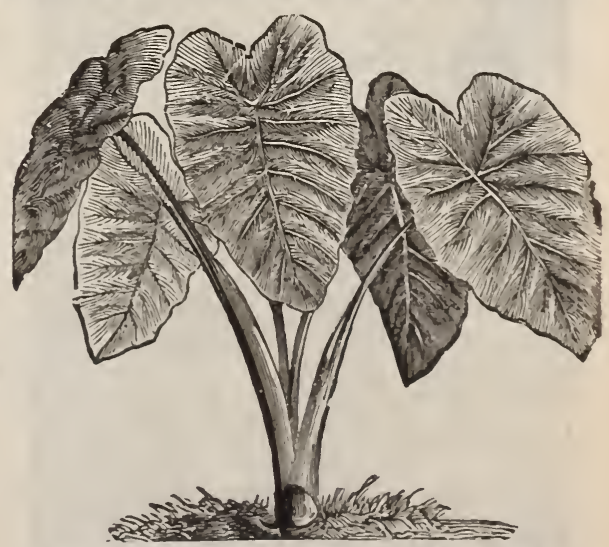

\section{GALADIUM ESGULENTUM}

Commonly known as Elephant's Ear.

Very effective and suitable for either a single plant on the lawn, masses in beds or margins of water. Its very distinct lesves often attain the length of three feet by twenty inches wide, and have a rich, tropical effect. Price. for nice bulbs of Caladium, 10c each; large bulbs, $25 \mathrm{c}$ each. 


\section{LILIES $\stackrel{\text { FOR }}{=}$ SUMMER BLOOMING}

Lilium Auratum, Golden Rayed Queen of Lilies-The grandest Lily grown. The perfume is exquisite, light, zet penetrating. Magnificent by daylight, grown. The perfume is exquisite, light, yet penetrating. Magnificent by daylight, indescribably beautiful. Also known as "Gold Banded Lily from Japan." Price, $30 \mathrm{c}$ each; four for $\$ 1.00$. (See cut.)

Lilium Rubrum-White ground, with bands and spots of rose or crimson on each petal. One of the best Lilies. Price, 20c each.

Double Tiger Lily, Tigrinum fl. p1.-This magnificent Lily is borne in immense clusters on tall stems; the flowers are very large, frequently six inches across and very double; color, deep fiery red, spotted with black. Price, 15c each.

\section{* LILIUM SPECIOSUM MONSTROSUM ALBUM. *}

A variety of the above, with broad, flat stems and immense heads of tlowers. Pure white and very fragrant; petals gracefully recurved; a very fine sort. Price, $20 \mathrm{c}$ each.

\section{* * * LILIUM CANDIDUM. * * *}

The Madonna or Annunciation Lily-This Lily is the emblem of purity. The deep lemon anthers contrast beautifully with the wax like petals. The fragrance is delicious and never oppressive. It is one of th
in the house or outside. Perfectly hardy. Price, $15 \mathrm{c}$ each.

\section{* STATELY GLADIOLI * AND FRAGRANT TUBEROSE}

\section{T UBEROSES.}

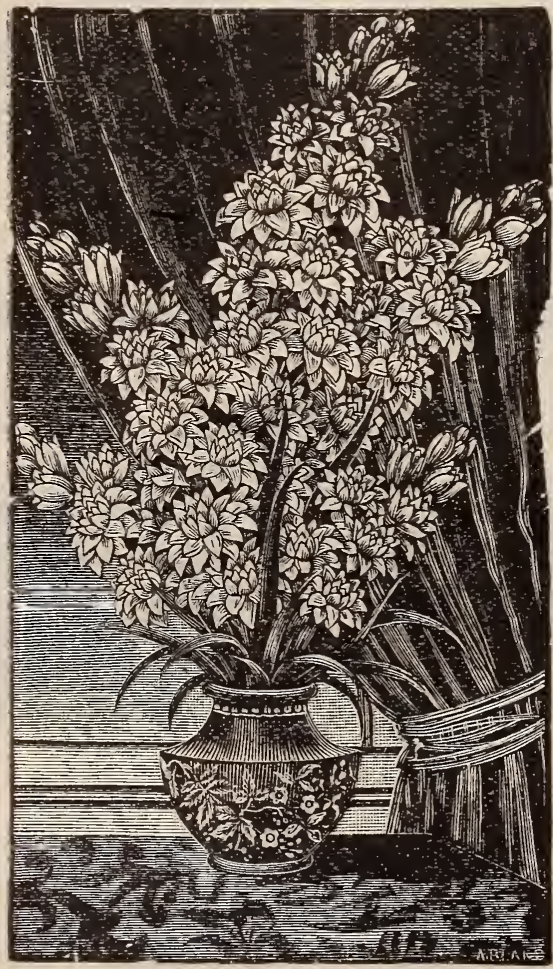

TUBEROSE BLOOMS.

Excelsior Pear1-Its pure waxy color and delight ful fragrance make it the most popular of all flowers for bouquets and baskets. Our bulbs are very fine, and we gurantee that all will bloom

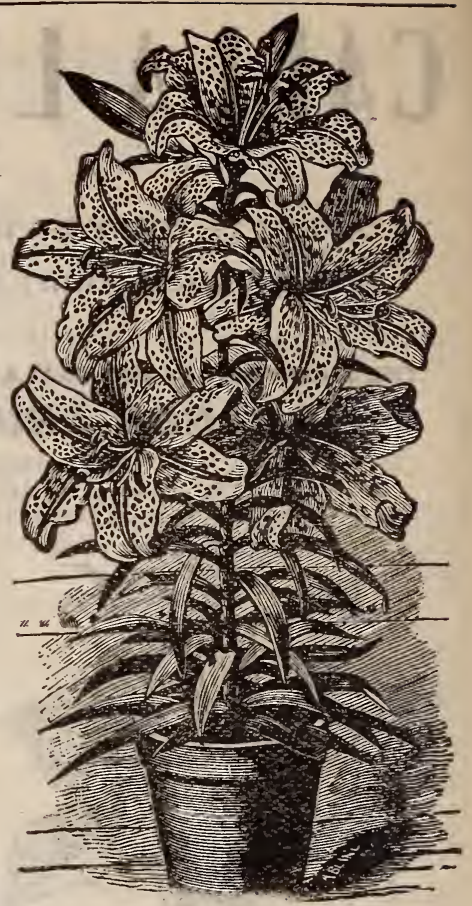

LILY AURATUM.

G L A D I O L I.

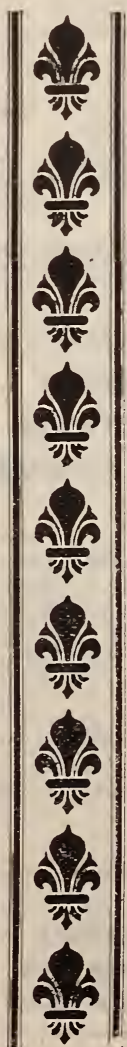

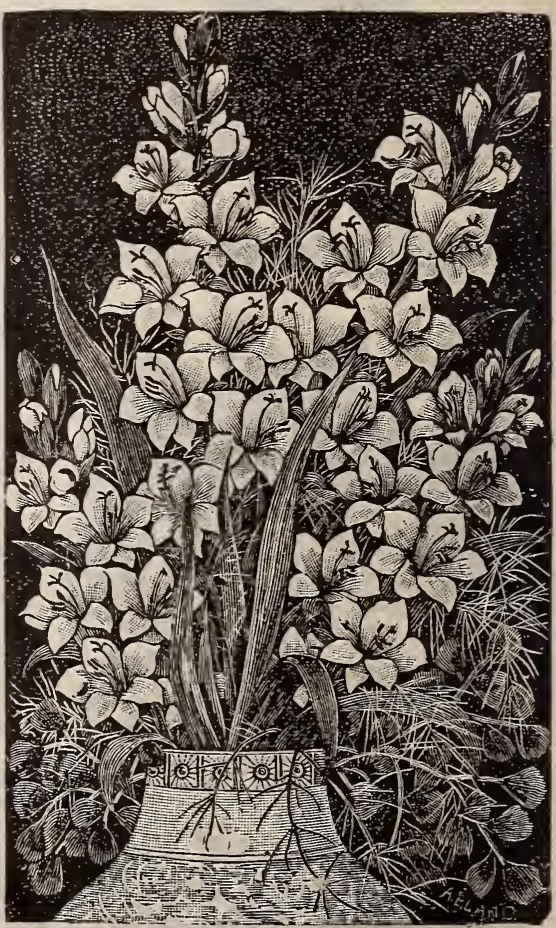

GLADIOLI BLOONS.

Our Gladioli can be relied upon to bloom freely, and embrace all shades of buff, salmon, pink, crimson, yellow, white, lemon, rose, maroon, scarlet, cherry and
variegated varieties. Large bulbs, $5 \mathrm{c}$ each; 12 for $50 \mathrm{c}$. 


\section{BEAUTIFUL HARDY PLANTS AND VINES}

SUITABLE FOR CEMETERY, LAWN AND GARDEN.

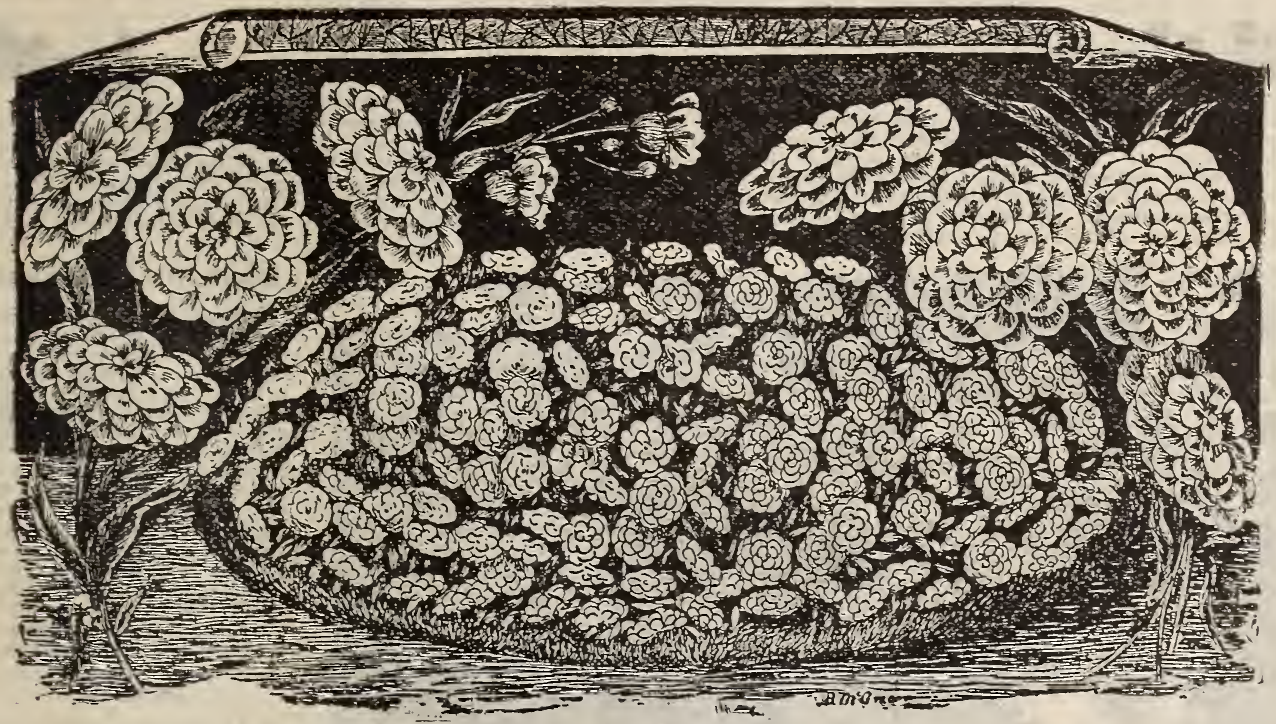

NEW ACHILLEA, "THE PEARL。"

The Great Cemetery Plant, the Pure White Hardy Achillea, "THE PEARL."

We take much pleasure in calling especial attention to this new plant, as it is one of the most beautiful and useful. It is a hardy perennial, the top dying down to the ground every Winter. A plant will produce hundreds and even thousands of flowers the first Summer, but when established the second rear frequently have more than five hundred perfect flowers on the plant at the same time. It commences to bloom early in July, is a perfect mass of beautiful flowers till frost, the same bloom keeping perfect two or three months. Its flowers are pure and white, perfectly double, and produced in large sprays, making it one of the finest cut flowers for bouquets, vases, baskets, etc., or for any kind of decoration. For cemetery planting it is the most valuable of all flowers, as it is sure to thrive and bear its great profusion of snow-whit flowers nearly the whole Summer. Price, $8 \mathrm{c}$ each; four for $25 \mathrm{c}$. twelve for $60 \mathrm{c}$.

\section{LILY OF THE VALLEY.}

One of the most charming Spring flowering plants, producing in profusion its delicate bell-shaped, delightfully fragrant white flowers. It will thrive in any common soil, and will do well in shady situations where few other plants will succeed. Price, three for $10 \mathrm{c}$; twenty for $50 \mathrm{c}$.

New Japanese Hardy Hydrangea,

\section{PANICULATA *}

\section{* GRANDIFLORA}

A new, very striking and elegant hardy flowering shrub; suitable for lawns, recently introduced from Japan. The flowers are pure white, afterward changing to pink, and are borne in immense pyramidal trusses more than a foot long and nearly as much in diameter. It blooms in mid-summer and remains in bloom two or three months. The plant is of a bushy and compact growth. attains a height of three to four feet, and is perfectly hardy in all parts of the country; needs no protection of any kind. See cut.

Price, young plants, 15c each; extra strong two-year-old plants for im. mediate effect, $35 \mathrm{c}$ each.

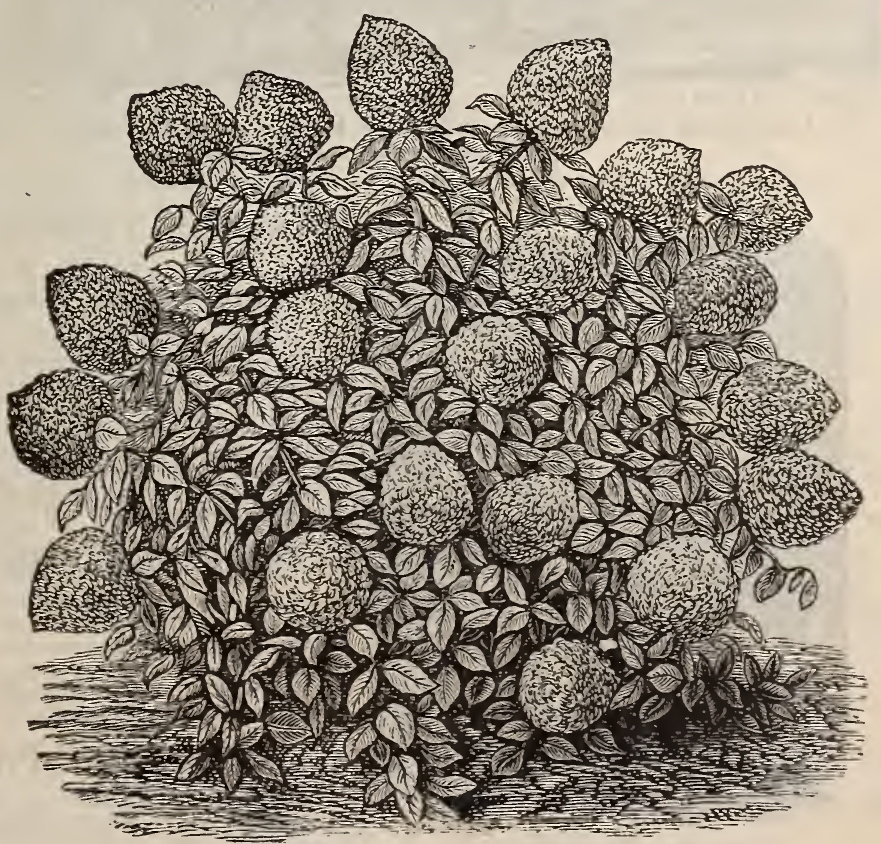

THE HARDY HYDRANGEA 
HARDY PLANTS AND VINES-Continued.

\section{RED, WHITE AND BLUE CLEMATIS.}

|| $\begin{aligned} & \text { The Climbers on this Page are all Hardy in } \\ & \text { any Latitude, and are indeed Superb.......... }\end{aligned}$

THE CLEMATIS is, perhaps, the most popular climbing plant of the day, and is constantly gaining in popularity. Entirely 1 hardy, blooming the entire season, embracing great variety of color, of the most beautiful tints of blue, purple, lavender, scarlet, white, etc; ; double and single, some of the flowers being six inches in diameter; and from their wavy graceful contour, when wafted by a slight breeze. the flowers resemble huge butterflies hovering among the green leaves. They are all climbers, and if trained carefully attain a height of from five to fifteen feet in one season. Hardy, but a light covering of cannot throw up wild shoots, as grafted plants are apt to do.

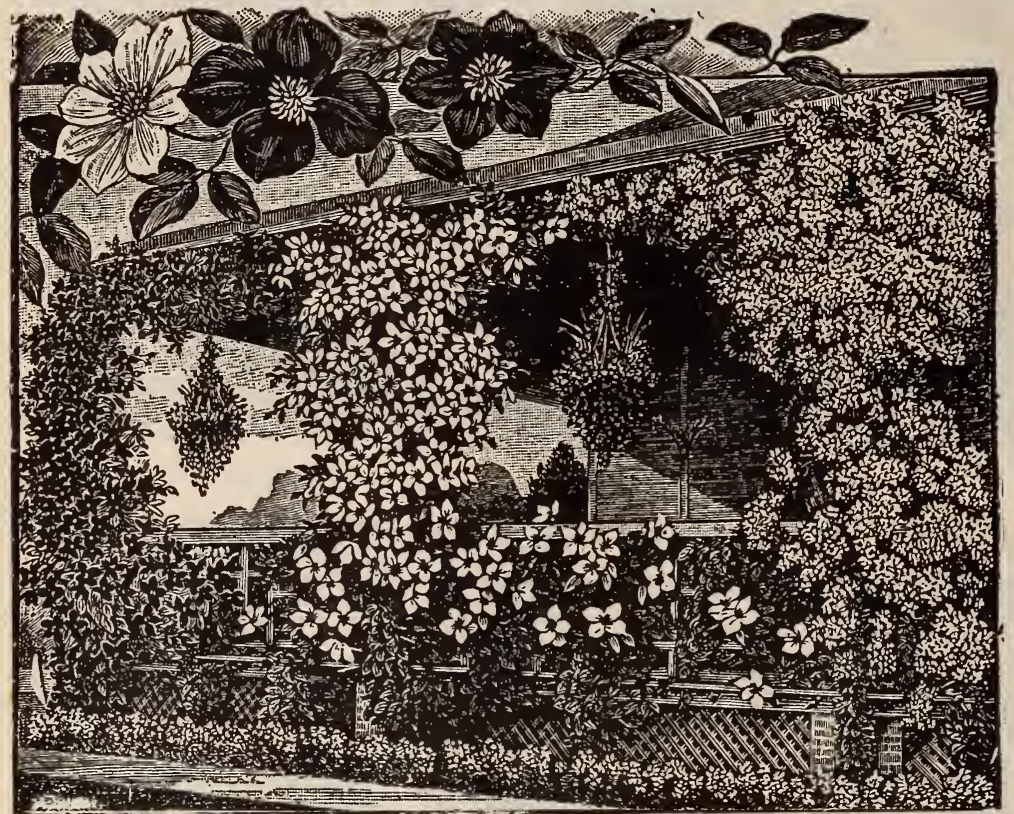

Clematis Jackmanni.

Its rapidity of growth, match less freedom in blooming, and the superb velvety-purple of its: large flowers have always been other Clematis which Jacqueminot holds to other hardy Roses. The blooms are royal. coming in great numbers continuously from July until Winter. Perhaps three times as. many Jackmanni are grown as all the other varieties combined. We would urge the planting of the larger size, as better and quicker results will thus be obtained. Price, 75c each; extra large fine plants, $\mathbf{S 1}$.

\section{Henryii.}

La r ge, pure white, single flowers. Price, $75 \mathrm{c}$ each; extra. large plants, \$1 each.

Viticella Rubra Grandiflora.

A vigorous, free-growing variety; flowers profusely. Color, violet-red. Price, $75 \mathrm{cts}$.

Clematis Paniculata.

The flowers are of the medium size, pure white, borne in immense sheets, and of a most delicious and penetrating fragrance. These flowers appear in September, at a season when very few other vines are in bloom. Price, 25c each.

The four varieties; Red, White andi Blue for $\$ 1.75$, no further discount.

CLEMATIS JACKMANNI. CLEMATIS HENRYII ing are very Large and
to Flower this Summer.

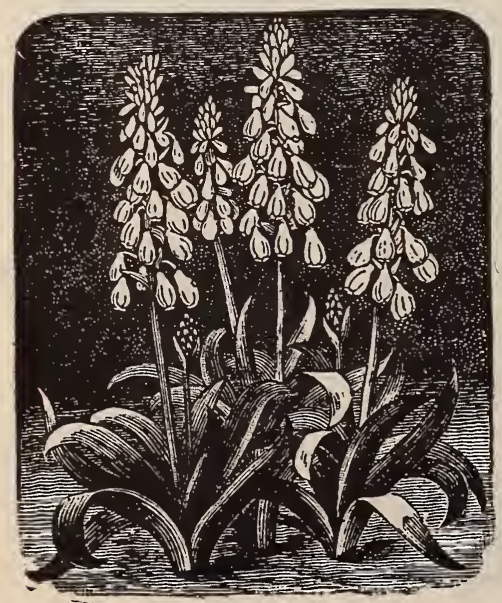

HYACINTHUS CANDICANS.

\section{HYACINTHUS CANDICANS}

A very stately bulbous plant, with large Yucca-like leaves, growing as high as four feet. The flowers are pure white, the number of flowers vary from twenty to sixty on each. With us the plant is perfectly hardy and grows stronger each year. It is very suitable for cemetery decoration, for centers of beds, or for grouping wherever it can have room to display its very distinct and expressive character. Price, $10 \mathrm{c}$ each; three for 25 c.

\section{CHINESE BLUE WISTARIA.}

One of the most beautiful of all Wistarias; a vigorous, strong-growing vine producing in early Summer a great profusion of large clusters of lovely, rich, violet-blue flowers, deliciously sweet; handsome. Price, 10c each.

\section{CINNAMON VINE.}

A fine hardy climber. The vine is a beautiful rapid grower, producing sweet scented flowers. Price 8c each; four for $25 \mathrm{c}$,

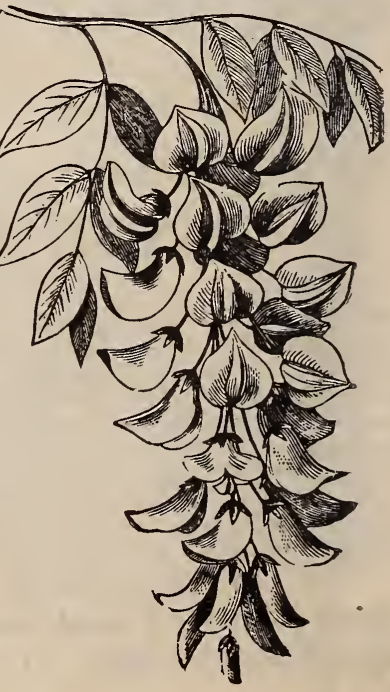



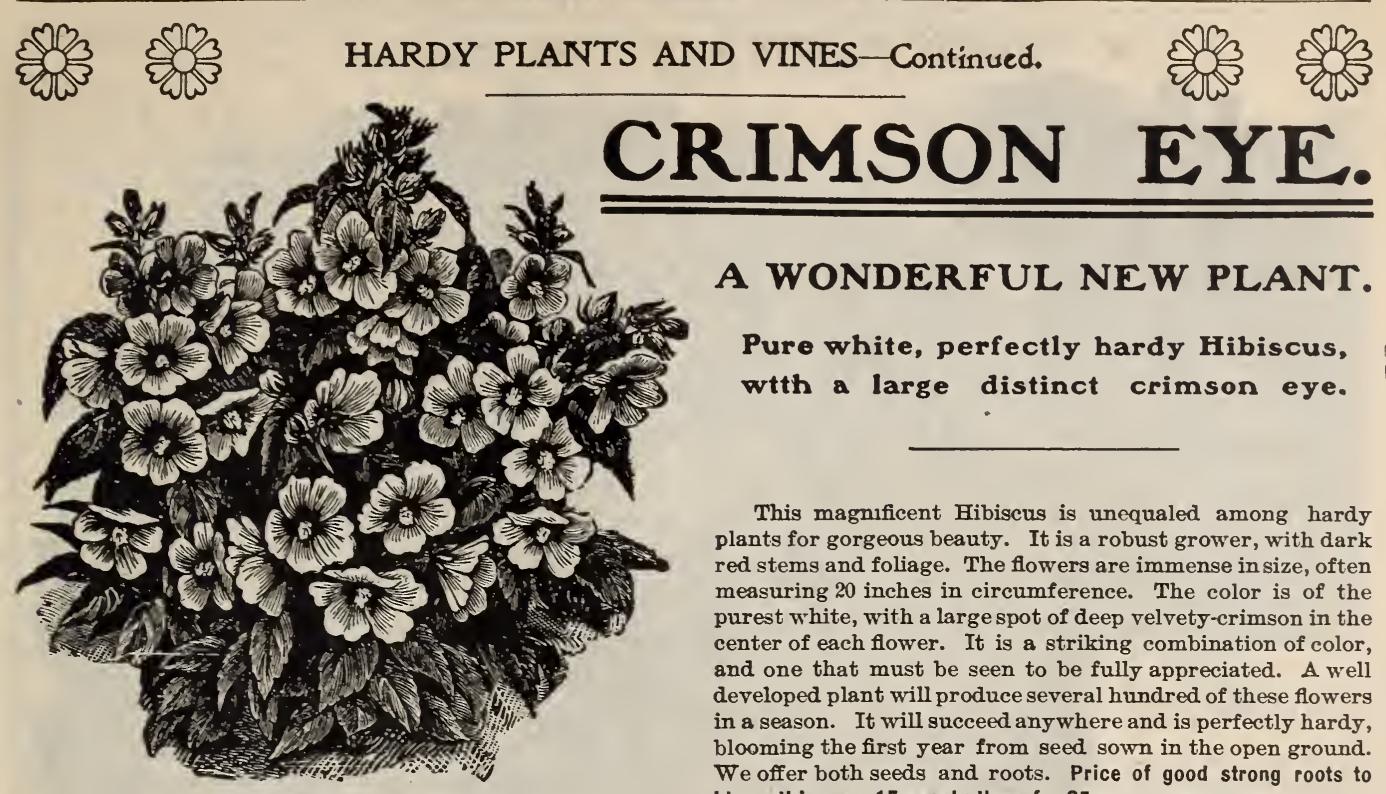

\section{A WONDERFUL NEW PLANT.}

Pure white, perfectly hardy Hibiscus, wtth a large distinct crimson eye.

This magnificent Hibiscus is unequaled among hardy plants for gorgeous beauty. It is a robust grower, with dark red stems and foliage. The flowers are immense in size, often measuring 20 inches in circumference. The color is of the purest white, with a large spot of deep velvety-crimson in the center of each flower. It is a striking combination of color, and one that must be seen to be fully appreciated. A well developed plant will produce several hundred of these flowers in a season. It will succeed anywhere and is perfectly hardy, blooming the first year from seed sown in the open ground. We offer both seeds and roots. Price of good strong roots to bloom this year, $15 \mathrm{c}$ each; three for $35 \mathrm{c}$.

\section{A BEAUTIFUL BLOOMING HARDY VINE. LOVELY FLOWERS AND A RAMPANT GROWER.}

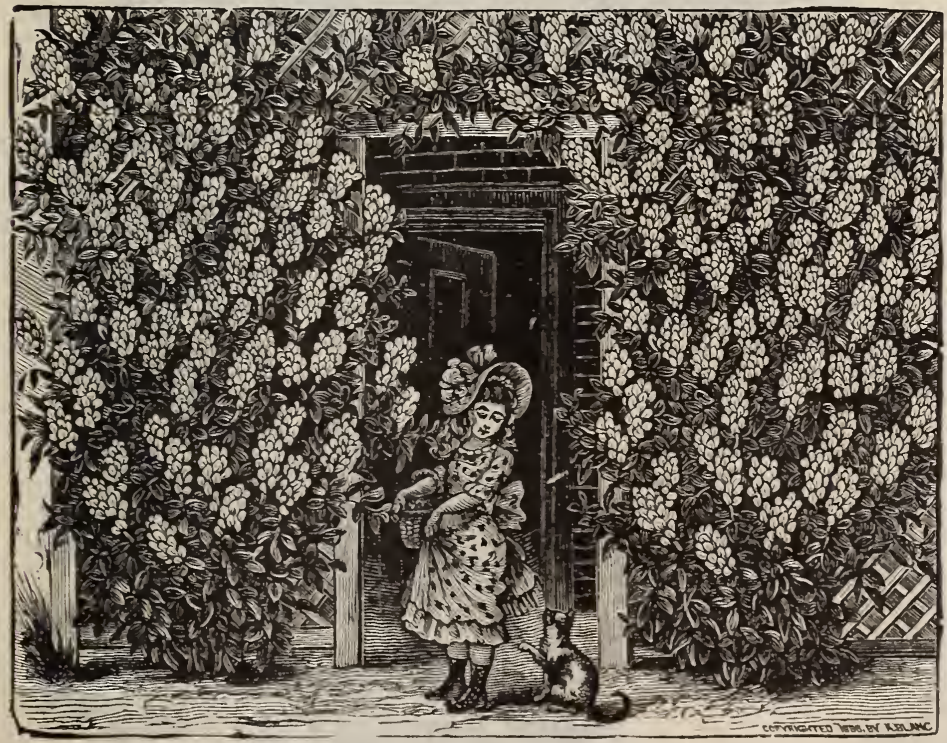

THE HARDY APIOS TUBEROSA.

THE BEAUTIFUL HARDY

\section{YUCCA FILAMENTOSA} (ADAM'S NEEDLE.)

A tropical looking plant, with long narrow leaves that remain green the entire year. It throws up a strong flower stem in the Summer, three or four feet high, bearing a large beauty a long time. Hardy. Price, 25c each.

\section{* A P I O S T U B E R O S A}

A hardy tuberous-rooted climber, closely resembling the common Wistaria in vine and foliage and having clusters of deep, purple flowers, which have a strong violet fragrance. Plant the bulbs near a trellis, fence, tree or any place where you may wish a climber. They grow to a great height and bloom profusely. The bulbs are perfectly hardy, and should not be taken up over winter. Price, $10 \mathrm{c}$ each; three for $25 \mathrm{c}$. See cut.

NOTE.-Last Spring our stock of Apios Tuberosa was sold out early in the season. Owing to its scarcity we could not get it. This caused some disappointment to our patrons.

We have this season however a very large supply and shall be able to fill all orders for this beautiful climber. 


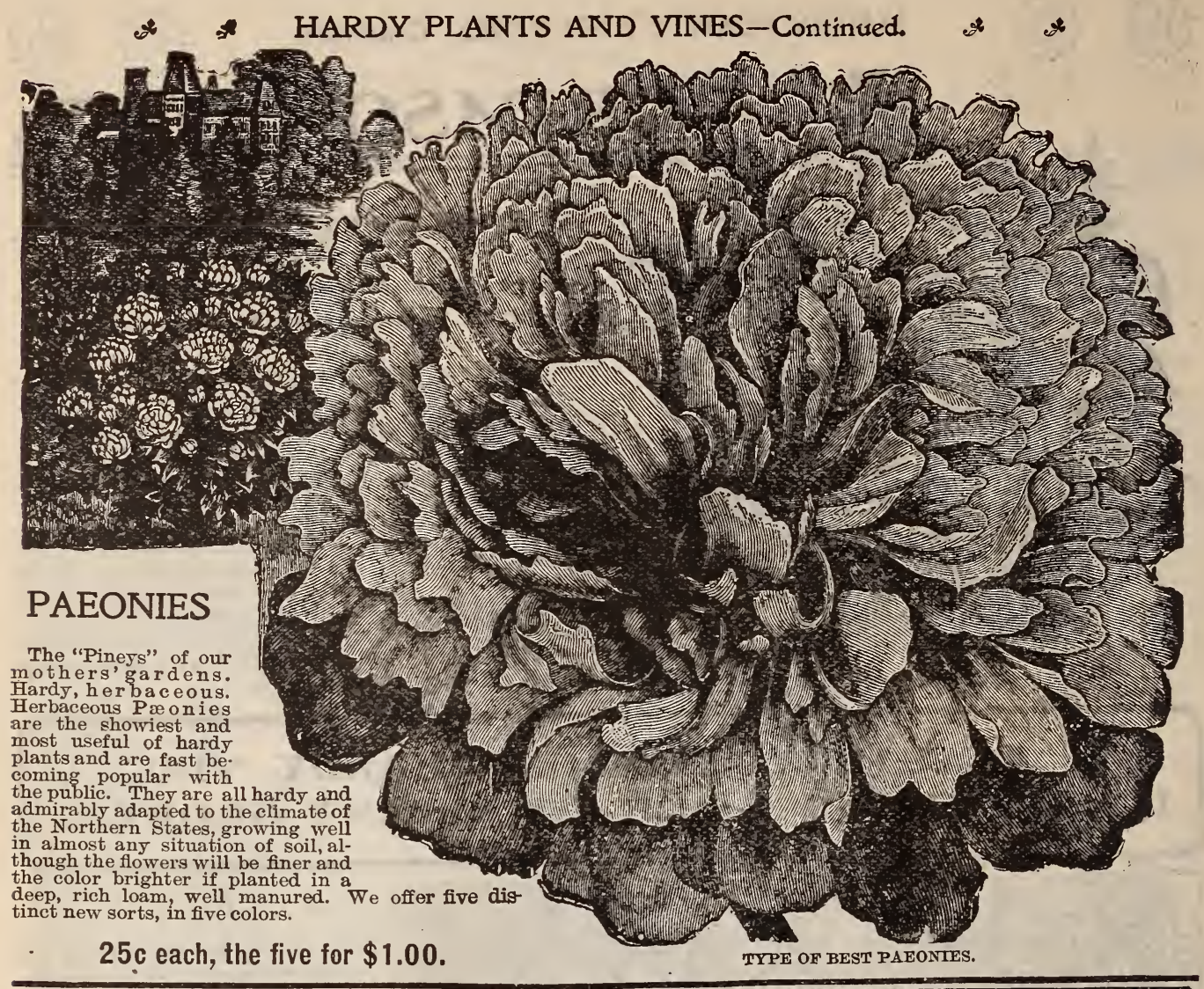

THE HARDY CHINESE MATRIMONY VINE

It is a most vigorous, hardy climbing plant when trained to an arbor, fastened to a fence, attached to a tree, the side of a house, the pillars of a piazza, or in any location where a hardy, vigorous climber is desired. It sends out numerous side branches, so that it covers a great amount of space in a short time, and every new growth is at once covered with bright purple flowers, which are succeeded by brilliant scarlet berries nearly an inch long, every branch being loaded with them. The contrast between the glossy, dark green foliage and shining scarlet fruit is exceedingly beautiful, surpassing Holly in appearance. It continues flowering and new berries are forming from late Spring until frost. The berries ripen in early Autumn and remain on the vine late into the Winter. The number of our hardy vines which can be grown without danger from frost in our Northern States is limited, and none are more beautiful than this or as easy of culture. It will grow and thrive in any situation, either shade or bright sunlight, and will take root in any soil. Price, young plants, which will bloom and fruit abundantly this year, $10 \mathrm{c}$ each; three for $25 c$

\section{The Splendid Hardy}

Climbing Vine

\section{* AMPELOPSIS VEITCHI *}

The popular Boston or Japan Ivy which clings firmly to any wall, tree, etc. The leaves, which are of an olive-green brown color, change to bright scarlet in the Autumn. This variety becomes more popu. lar every season, and is without question one of the very best climbing plants for covering brick, stone or wooden walls that can be grown. Nice plants, $15 \mathrm{c}$ each.

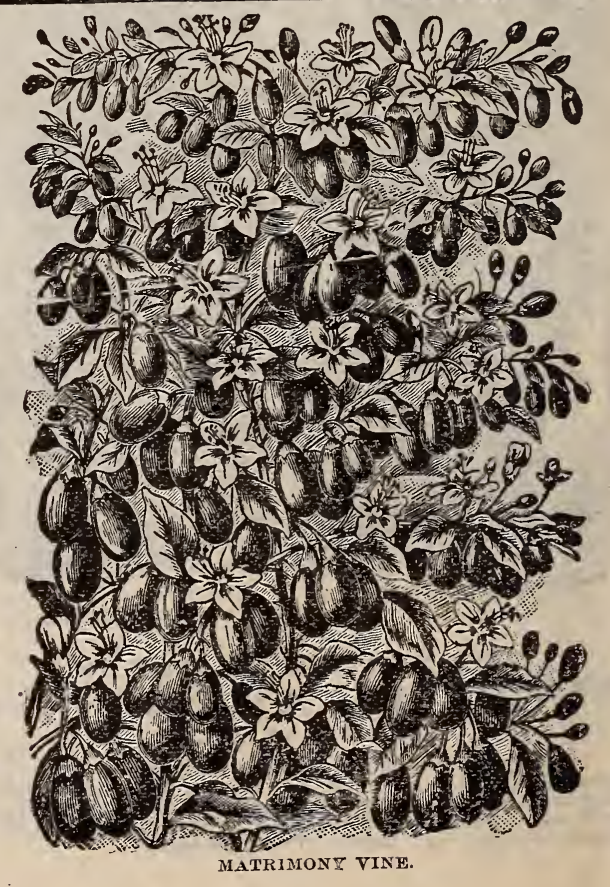




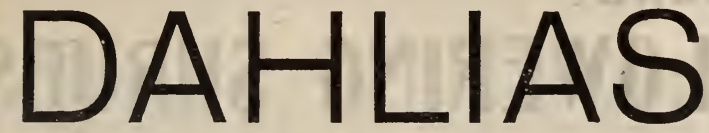

\section{EIGHT OF THE BEST}

VARIETIES * * * *

Within the last few years there have been many new varieties introduced of American and European origin, and the ones we have are the cream of hundreds of these varieties.

Price of these Beautiful Dahlias, - . 15 cents each The Full Set of EIGHT CHOICE SORTS $\$ 1.00$
For . . . . . . . . . $\$ 1.00$

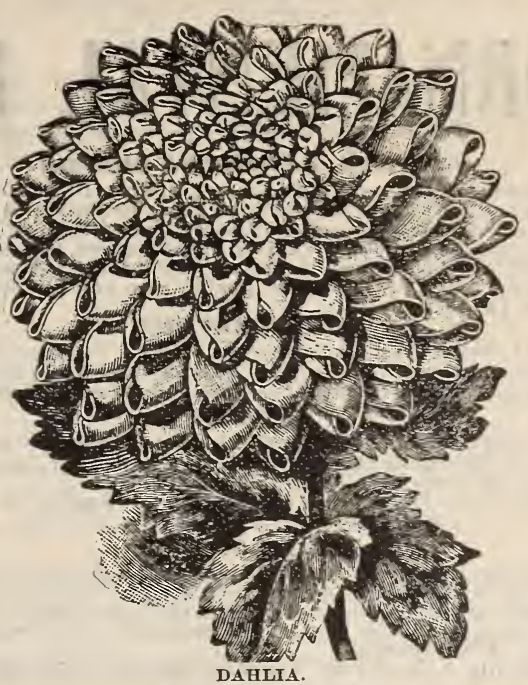

THE GRACEFUL DECORATIVE DRACAENA INDIVISA.

One of the most popular plants for house decoration or for the center of lawn vases. As a single specimen plant for a jardinier in a hall or drawing-room it has no equal. It is more graceful than a Palm, and because of its slender drooping leaves is often called a "Fountain Plant." The leaves are of several shades of green, with delicate stripings of yellow and red, which become marked as the Palm grows older. It grows rapidly, is adapted to the close atmosphere of the house, and is very inexpensive. Price, nice plants, 10 cents each; large plants, 20 cents.

\section{DRACAENA TERMINALIS.}

Superb species; rich, crimson foliage, marked with pink carmine and creamy white. Words cannot describe the exquisite coloring. This is one of the most admired of the decquisite coloring. Thise species, its elegant habit and extremely beautiful, lively coloring, giving it marked value. It is a rapid grower and for room adornment or as a vase plant for out-of-door use it is indispensable. Price, 35 cents each; extra large plants, by express, 60 cents each.

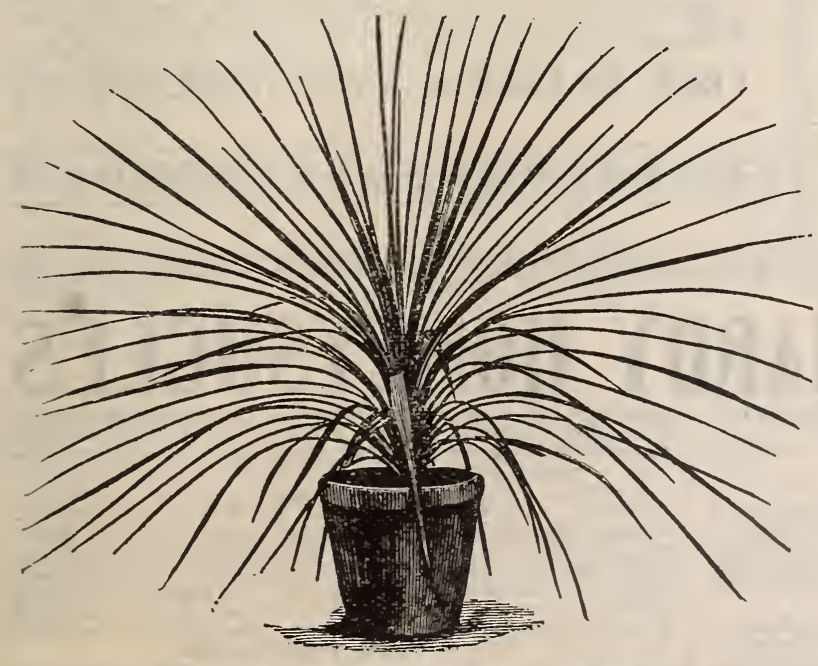

DRACENA IN SIX-INCH POT.

\section{CROWN OF THORNS- EUPHORBIA}

A curious plant, with thick, fleshy, twining stems, which are covered with stout, sharp spines nearly an inch long. There is a tradition that this plant furnished the material for the "Crown of Thorns" used in the divine tragedy. The foliage is bright green and the flowers are beautiful coral-pink, very pretty when in bloom. Price. $15 \mathrm{c}$ each.

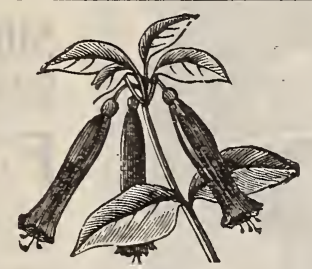

CUPHEA

\section{PLATYCENTRA}

\section{GIGAR PLANT.}

Scarlet, pendulous flowers; neat, compact habit; constant bloomer. Price, 8 cents each; FLOWER OF CIGAR PLANT. three for 15 cents.

THE PRETTIEST AND MOST USEFUL OF ALL DECORATIVE VINES ......

VINCA, MAJOR VARIEGATA

This is a beautiful variegated trailing vineadmirably adapted for hanging baskets and vases. The leaves are a glossy green, broadly margined a creamy white; flowers blue. More Vincas are employed in vase and basket work than all other of four-inch pots, 20 cents each.

\section{NEW CUPHEA TRICOLOR}

This elegant plant is of low-growing habit, forming a very unique plant that is well covered with brilliant, tube-shaped flowers. Therareand beautiful combinations of colors display ed in the flower are red, white and blue, which is at once suggestive of its resemblance to the National Flag. It is well adapted for general uses, such as bedding out, pot culture or hanging baskets. Makes a pretty and showy border. Price, 10 cents each; three for 20 cents.

TRANDESCANTIA MULTICOLOR, or WANDERING JEW.

Nearly every one is acquainted with the old Zebrigna. The one now offered is the most beautifully variegated purple, scarlet and white. Price, $6 \mathrm{c}$ each; three for $15 \mathrm{c}$. 


\section{ORNAMENTAL FLOWERING SHRUBS}

\section{ALTHEA, or ROSE OF SHARON}

Flowers of large size, bell-shaped, double, full and of brilliant and striking colors, borne in greas profusion in August lant and string and September, when other fowers are scarce. Of regular and compaot growth, with deep, glossy-green leaves. Make wherever seen. Two colors, double rose and double white. Price, $16 \mathrm{c}$ each.

\section{CALYCANTHUS}

)

The well-known sweet-scented shrub. It bears in May a profusion of double, purple blossoms, which have a strong, delicious pineapple fragrance. Price, $15 \mathrm{c}$ each; extra large, $30 \mathrm{c}$.

\section{DEUTZIA}

Gracillis-A charming shrub. Flowers pure white, bellshaped, delicately fringed, and borne in such profusion as to cover the branches. Price, $15 \mathrm{c}$ each.

Crenata-Four feet in height, flowers double, of a pure white, beautifully tinged with rose. Price, $15 \mathrm{c}$ each.

\section{LILACS}

White Lilac-As a decorative plant on the lawn or in the border it is without a peer, and its pure white graceful plumes of sweetly fragrant flowers add grace and beauty to bouquets, vases, etc. As a cemetery plant, it is without a rival. Price, 50c each

Purple Lilac-Price, $25 \mathrm{c}$ each; large plants. $50 \mathrm{c}$ each.

SNOWBALL

A grand old shrub which we all remember in childhood, producing in June large round balls of snow-white bloom, which droop from the branches gracefully. Price $25 \mathrm{c}$ each.

\section{SYRINGAS}

Mock Orange-These lovely, hardy. exquisitely fragrant flowering shrubs should be in every garden. Indeed, the oldfashioned, sweet-scented Mock Orange (so-called because of the exquisite fragrance of the flowers, like orange-blossoms is known to all lovers of plants. Price, $15 \mathrm{c}$ each.

Primulaefolus-Flowers large, of delightful fragrance, double, white. star-shaped, resembling the double white Primula; produced in bunches of five to seven; hardy. Price, $15 \mathrm{c} \mathrm{each}$.

\section{SPIREAS}

These are beautiful shrubs of easy culture, Very desirable for shrubberies or the flower garden. Price, $15 \mathrm{c}$ each.

Ballardi1-Flowers in spikes of pink or rose color.

Van Houtte-A strong grower, flowers a pure white, in clusters. Fine. The best.

\section{WEIGELIAS}

Candida-This is the very best of all the white-flowered Weigelias: white and produced in great profusion. Price, $20 \mathrm{c}$ each,

Variegated Leaved-Deep green leaves, broadly margined yellowish-white. Very striking aud pretty. Flowers same as above. but of smaller growth. Price; $20 \mathrm{c}$ each.

Rosea, Nana-One of the most conspicuous shrubs that we cultivate; flowers pink. It is a dwarf grower and admirably adapted to small lawns or gardens. Price, 20c each.

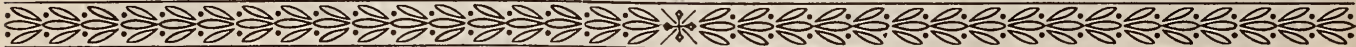

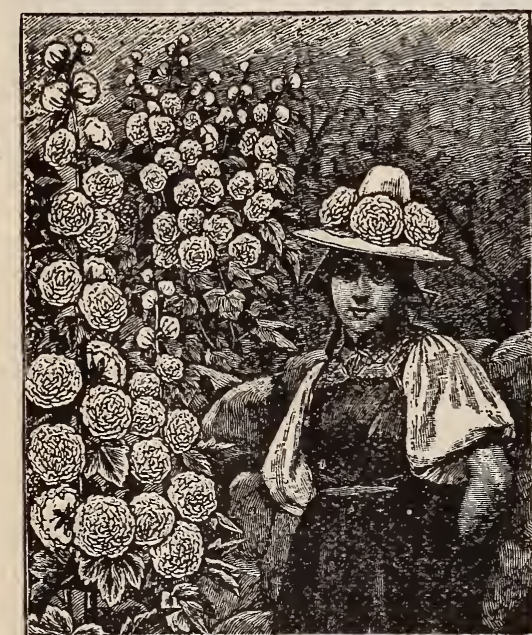

HARDY HOLLYHOCKS.

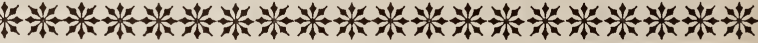

SUPERB DOUBLE

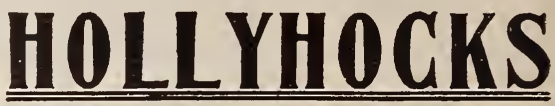

EW PLANTS combine as many good qualities as the Hollyhock.

For planting in rows or groups on the lawn, or for interspers-

ing among shrubbery, they are invaluable. The flowers form perfect rosettes of the most lovely shades of crimson, pink, and white. The Hollyhock requires a rich, deep soil, well drained, anả will repay in quantity and elegance of bloom any extra care. A slight protection during the winter will be beneficial. (See cut.

We offer strong one-year-old plants that are certain to produce grand spikes of flowers this season in the following colors, viz. Red, White, and Pink. 0 PRICE, 10c EACH * * THE THREE FOR 25c

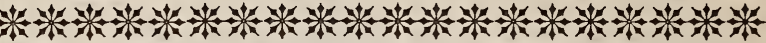




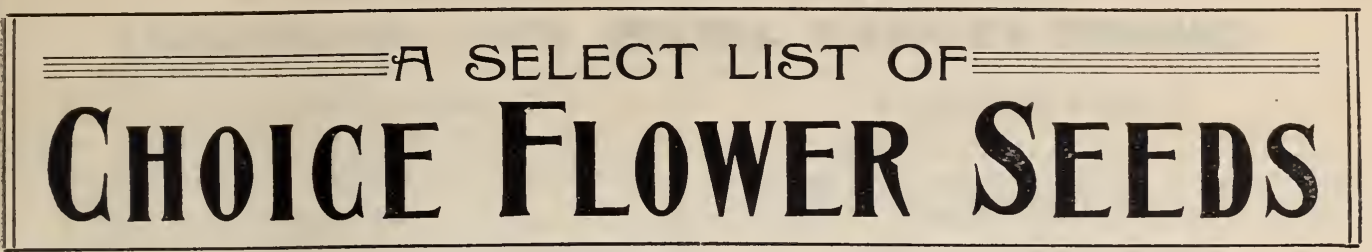

\section{ASTERS (Fall Roses)}

The Aster is one of the most popular and effective of our garden favorites. Sow early in the house, and transplant into pots or boxes. As soon as the weather is warm enough, plant pots or boxes. As soon as the wart. Half-hardy annuals.

Mignon-A new Aster of a great beauty. Plants about fifteen inches high. Very bushy and prolific. Flowers of good size, reflex petals and very double. It is splendid in pots or the open ground. Finest mixed colors. Price, $10 \mathrm{c}$ per packet

Comet-Forming regular pyramids twelve to fifteen inches high, and covered with large double flowers. In shape they represent a large flowered Japanese Chrysanthemum, the petals being long and twisted, or curled and wavy. Price, 10 c per packet.

Dwarf Pyramidal Bouquet-A magnificent dwarf variety, about one foot high. When full grown a single plant forms a complete bouquet of pyramidal shape, and covers forf with blossoms, of ten numbering fifteen or twenty flowitself with blossoms, of ten numbering firteen or twenty low small beds. Fine mixed. Price, 10c per packet.

New Dwarf Preony, Perfection-Grows only twelve inches high; of very neat, compact habit and flowers most profusely. The flowers are of very large size and fine form, perfectly double, the petals beautifully incurved. The colors pre particularly rich and brilliant and the refined form of the flowers attracts great attention while in bloom. Fine mixed. Price, 10c per packet.

New Victoria-A very free bloomer; flowers very large and beautifully imbricated; one of the finest; plant pyramidal form; two feet high; all colors mixed. Price, $10 \mathrm{c}$ per packet.

New Victoria White-One of the finest white varieties; flowers large, perfect in form, and of the purest white. Price, $10 \mathrm{c}$ per packet.

\section{EXCELSIOR PACKET OF ASTERS}

This packet contains a fine mixture made from the above choice varieties. Price, $10 \mathrm{c}$ per packet.

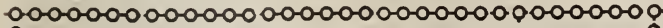 $\$$ SPECIAL OFFER-We will send one packet of each $\$$ of the above named varieties for $50 \mathrm{c}$. This will make a beau- $\$$ tiful bed of Asters at a low price. No further discount on this collection.

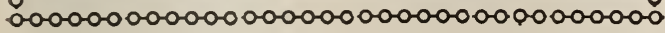

\section{AGERATUM}

A beautiful Mexican plant, much prized on account of the large number of flowers it bears ; remains in bloom all Summer. Also suitable for pot culture.

A geratum Mexicanum-Finest mixed. Price, $5 \mathrm{c}$ per packet.

\section{ALYSSUM}

The delicate honey-like fragrance of the flowers of this little plant, so much prized in bouquets, baskets and design work, render it most unlikely that this old favorite will ever be cast aside. Easy culture, blooms all Summer; 12 inches.

Alyssum, Sweet-The well-known white variety. Psice, $5 \mathrm{c}$ per packet.

Alyssum, Little Gem-New. Very divarf; three or four inches high. Price, 5 c per packet.

\section{ANTIRRHINUM (Snap Dragon)}

The Snap Dragon is an old favorite border plant, with dark, glossy leaves, and large, curiously-shaped flowers, with finely marked throat. They bloom the first season from seed sown in the Spring, but the blossoms will be much stronger the second season. Price, $5 \mathrm{c}$ per packet.

\section{CHRYSANTHEMUM}

Most showy Chrysanthemum can be raised from seed. The varieties we offer are the best in color, very double, and will make excellent flowers for cutting. Try it. Price, 10c per packet.

\section{NEW DEFIANCE BALSAM}

Balsam, Choice Double-All colors. Mixed. Price, бc per packet.

\section{CUCUMBER (Wild)}

A rampant climber, fine for shade. Price, $5 \mathrm{c}$ per packet.

\section{CANTERBURY BELLS (Campanula)}

A well-known free bloomer of great beauty; effective for beds or pot culture. Flowers of many colors, large, bellshaped; succeeds best in light, rich soil. Sow seed esrly in the open ground; cover lightly; thin or transplant to twelve inches. Hardy biennial. Price, mixed single varieties, $5 \mathrm{c}$ per packet; mixed double varieties, $5 \mathrm{c}$ per packet.

\section{CANDYTUFT}

Universally known and cultivated, and considered indispensable for cutting. All the varieties look best in beds or masses. Seeds sown in Autumn produce flowers early in the Spring; when sown in April they flower from June to September, and some of the sorts till frost comes.

Candytuft, Finest Mixed-Including all the choice varieties. Price, Бc per packet.

\section{CARNATION}

Marguerite Carnation-Flowering in a few weeks from seed. Most abundant bloomers; flowers very double, ranging through beautiful shades of reds, pinks, white, variegated, etc. These sown in Spring commence flowering in early Summer, and continue to bloom until checked by frost. They can be potted and taken to the house and will flower abundantly throughout Winter, though if intended specially for Winter flowering, it will be better to sow later in the season. Mixed colors. Price, 10: per packet.

\section{CALLIOPSIS (Golden Wave)}

This splendid showy annual is unsurpassed for bedding, bordering, hedges, shrubbery, etc. It is a perfect mass of golden-yellow, well meriting its name, "Golden Wave." The bushy and compact plants grow about two fert high, and from June to October are densely covered with beautiful yellow blossoms, each with a small, dark center. Seeds can be sown in open ground or transplanted; plants will grow with little care in any situation, and attract great attention. Price, $5 c$ per packet.

\section{CENTAUREA (Blue Bottle or Batchelor Button)}

One of the most attractive of all hardy annuals, the graceful beauty of its old-fashioned flowers being universally admired. A hardy annual of the easiest growth, and flowers freely and continuously; height two to three feet. Flowers excellent for cutting. Price, $5 \mathrm{c}$ per packet.

\section{CROZY'S DWARF CANNAS}

These new dwarf, ever-blooming, large-flowering French Cannas bloom freely the flrst year from seed. They are much less expensive and more beautiful for bedding even than the best Geraniums. The roots can be kept in the cellar over Winter, and each clump will give six to eight good roots for planting out the following Spring. The mixed seed we offer has been saved from the finest varieties of all colors. Price, $10 \mathrm{c}$ per packet.

\section{COSMOS HYBRIDUS}

One of the most showy and graceful of all garden flowers, and nothing can give greater satisfaction for a late display. They make very large plants, growing five to seven feet high, which are beautiful masses of the most elegant foliage until they begin to bloom in September, when each plant will have hundreds of large showy blossoms. packet.

Iixed Colors-White, crimson and pink. Price, $5 \mathrm{c}$ per

\section{COLEUS}

Plants with richly colored foliage of maroon, green, crimson, zellow, etc. For groups on lawns and ribboning they are indispensable, and also valuable for pot culture. Although perennials, they attain perfection from seed the first season. Price, fine Hybrids, mixed, $15 \mathrm{c}$ per packet. 


\section{CHOICE FLOWER SEEDS, ETC. (Continued.)}

\section{COBCEA SCANDENS}

Unsurpassed for beauty by any annual vine. A very rampant grower, without a trace of coarseness; the flowers of the most elegant form; the soft gray-green of the long flexible color of the flowers. Price, $10 \mathrm{c}$ per packet

\section{CYPRUS VINE (Ipomœa)}

This is a most beautiful climber, with a delicate darkgreen, feathery foliage, and an abundance of bright, star-
shaped, rose, scarlet and white blossoms, which, in the bright sunshine, presents a mass of beauty. Planted by the side of a veranda, tree or stake, and trained properly nothing is prettier. The seeds will sprout more readily if warm water is poured on the ground after sowing. Price, choice, mixed colors, 5 c per packet.

\section{DOUBLE DAISIES}

This beautiful little Daisy is indispensable for cool, shady places, pots ind frames. With protection they will stand the
Winter, and greet us in the early spring with a profusion of gay flowers. They bloom beautifully in the house during the Winter and Spring, when cultivated in pots, and we highly recommend them for this purpose. In the garden treat them like Pansies.

Double, Mixed Colors-White, pink, rose, etc. Price, $10 \mathrm{c}$ per packet.

\section{DAHLIAS}

Extra Choice-Large flowering and double. Price, 10c per packet.

\section{DUTCHMAN'S PIPE}

A rapid growing vine, with large, heart-shaped foliage and curious, yellow and brownish-purple flowers, resembling a pipe. Hardy perennial. Price, $10 \mathrm{c}$ per packet.

\section{EICHOLTZIA}

California Poppy. Mixed; all colors. Price, $10 \mathrm{c}$ per packet

\section{FEVERFEW}

This popular plant can be easily grown from seed.

White-Price, $5 \mathrm{c}$ per packet.

White with Yellow Foliage-Price, $5 c$ per packet.

\section{FORGET-ME-NUT}

The Forget-Me Not is an old favorite, bearing clusters of delicate blue flowers.

B1ue Forget-Me-Not-Price, $5 \mathrm{c}$ per packet.

Mixed Forget-Me-Not-Pink, blue and white. Price, 6c per packet.

\section{HOLLYHOCKS}

The flowers as double as a Rose and embrace all shades of red, pink, yellow, crımson, white, etc. We offer seeds from an unsurpassed collection. Mixed colors. Price, 10c per packet.

HELIANTHUS, SUNFLOWER, NEW MAMMOTH RUSSIAN

Very large. Price, 5c per packet.

\section{HELIOTROPE}

Every one loves the delightful fragrance and beauty of the Heliotrope, but very few are aware of the fact that it can be raised from seed as easily as Verbenas. From seed sown in the open ground the plants will flower in August, while a fine display can be had earlier by starting the seed in the house and setting out plants when the weather is warm.

Choice Mixed-Of many varieties. Price, $10 \mathrm{c}$ per packet.

IMPATIENTS SULTANA

The Sultan's Balsam; brightscarlet. Price, 10c per packet.

\section{IPOMCEA, or MOONFLOWER}

White Moon Flower-Price, $5 c$ per packet.

Iight Blue Moon Flower-Price, $5 \mathrm{c}$ per packet.

\section{LATHYRUS LATIFOLIA}

Perennial, or Everlasting Pea. All colors. Price, 5c per packet.

\section{LOBELIA}

All the choice colors mixed; fine for baskets. Price, $5 \mathrm{c}$ per packet.

LAWN GRASS SEED

The best mixture. Price, $25 \mathrm{c}$ per quart.

\section{LANTANA (Finest Mixed)}

Well-known shrubby plants, with clusters of verbenalike flowers; make a grand display the first season. In full flower all Summer; much admired. Price, $10 \mathrm{c}$ per packet.

\section{LAVENDER}

An annual, bearing a very fragrant flower, used to lay among clothing to impart its sweetness. Everr woman should have a few plants in her garden. Price, $5 c$ per packet.

\section{LARKSPUR (Delphinium)}

Larkspurs are no longer the common annuals of fifty years ago. They are now most beautiful in color, have flowers of a hyacinth-like size and have dereloped so that no garden can afford to be without them.

Delphinium Larkspur-Double Dwarf Rocket: mixed. Price, $5 \mathrm{c}$ per packet.

Delphinium Larkspur-Double Tall Rocket; mixed. Price, 5 c per packet.

\section{MARIGOLD}

A swift growing annual that will make a great show of flowers, of all shades of yellow, orange, red and copper, for ittle care and with small expense.

African Mixed-All colors. Price, $5 \mathrm{c}$ per packet.

French Mixed-All colors. Price, $5 \mathrm{c}$ per packet.

\section{MUSK}

A small plant, easily grown, whose leaves are used as a perfume. Price, 5c per packet.

\section{MIGNONETTE}

Sweet Mignonette-(Reseda Odorata.) The good old-fashioned, sweet Mignonette. Price, 5c per packet.

Mignonette, Matchet-Of vigorous pyramidal growth with very thick, dark-green leaves. They throw up numerous stout flower stalks, bearing massive spikes of deliciously scented red flowers. Price, $10 \mathrm{c}$ per packet.

\section{MIRABILIS JALAPA}

(Marvel of Peru.) The plants are a solid mass of bright foliage and flowers that are exceedingly attractive. The flowers, which have a delicious fragrance, open in the afternoon; are sometimes called the Four O'Clock. Price, mixed colors, $5 c$ per packet.

\section{MORNING GLORY (Convolvulus-Major)}

The well-known Morning Glory. A fine, hardy and rapid grower, which always gives great satisfaction. They bloom early in the morning, and during the forenoon are brilliant with scores of beautiful flowers of various colors, white, pink, blue, scarlet, variegated, etc. Mixed, all colors. Price, 10c per packet.

\section{IMPERIAL JAPANESE MORNING GLORIES}

The flowers are of enormous size and of the most delicate vivid and blending colors to be seen in any flower. Some will be pure white, others crimson brick-red, light and dark blue, pink, etc., while others show a rich and varied combination of colors blended together in a most enchanting way. Spotted, blotched, striped, stained, penciled, bordered, mottled and variegated in every conceivable manner, to add to their beauty, the leaves of many of the varieties a re richly marbled and variegated white and green. Nothin a a mong flowers can furnish a more beautiful sight. Price, 10c per packet.

\section{NASTURTIUM}

Tom Thumb Nasturtiums-One of our showiest and most popular annuals. Compact plants, not over one foot high, making gorgeous masses of color. Mixed, many kinds. Price, $15 \mathrm{c}$ per ounce; $5 \mathrm{c}$ per packet.

Ta11, Mixed-Containing many beautiful varieties. Price.15c per ounce; $5 c$ per packet.

\section{NICOTIANA AFFINIS}

A good ornamental plant, with beautiiul, long, tubular white flowers of surpassing rich fragrance. The flowers are so fragrant that a few plants will perfume the whole surrounding atmosphere. Price, $5 c$ per packet.

\section{ZINNIAS}

No flowers are nore easily grown from seed sown in the open ground, and few bloom so continuously throughout the entire Summer. Those acquainted only with the old time Zinnias will be surprised at the perfection to which the newer strains have attained.

Choice, Double Mixed-Price, all colors, 5c per packet. 


\section{CHOICE FLOWER SEEDS, ETC. (Continued.)}

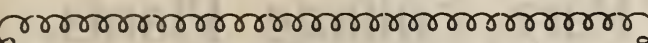
NEW GHOICE PANSY SEED

Our International Mixture has proven 6 more popular than we could have reasonably expected, and we may honestly clain it to be today not only the best, but the most widely known and adnired. A11 varieties and colors mixed. The very best mixture. Price, 610 cents per packet.

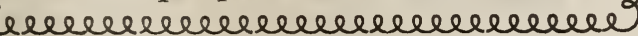

BEDDING PANSY SEEDJ

King of the Blacks-Rich as black velvet.

Pure White-Very delicate and sweet.

Clear Yellow-A most pleasing shade.

Red-Generally rich copper-colored.

Licht Blue-Delicate azure.

Each variety, 5 cents per packet.

SPECIAL OFFER-FIVE VARIETIES AS ABOVE FOR 15 CENTS

PENSTEMON

One of our most beautiful and attractive herbaceous plants bearing long, graceful spikes of rich-colored flowers. Mixed crimson, purple, etc. Price, $5 \mathrm{c}$ per packet.

Picotee Pink-Very much like the Carnation. As fine and more delicate in its coloring. Seed sown in the open ground in May or June will flower well the next season. Treat like the Carnation. Price, $15 \mathrm{c}$ per packet.

Peregrinum, Canary Bird Flower-One of the handsomest vines grown. Price, $5 \mathrm{c}$ per packet.

\section{PHLOX DRUMMONDII}

Alba-(Pure White) Our strain of this is magnificent, the flowers being of unusual size and perfect form; unsurpassed for bedding. Price, $10 \mathrm{c}$ per packet.

Leopoldii-Splendid deep pink with white eye. Price, 5c per packet.

Coccinea-Deep scarlet; most brilliant. Price, 5c per packet.

Violet Queen-Deep riolet, white eye. Price, 5c per packet.

Brilliant-Brilliant rose with dark red center. Highly effective Price, $5 \mathrm{c}$ per packet.

Choice Mixed-Our mixture is unexceller. Try it. Price, 5 c per packet.

Cuspidata-(Star of Quedinburgh.) The pointed central teeth of the petals (five in number) are five to six times as long as the lateral ones, and project beyond them, like little spines, one-fourth to one-half inch long, giving the flowers a distinctly marked, regular star-like form. Finest mixture of more than twenty colors. Price, $10 \mathrm{c}$ per packet.

\section{WALL FLOWER}

Single, Mixed.-All colors; two and one-half feet. Price, 5c per packet.

Finest Double-All colors. Price, $5 \mathrm{c}$ per packet.

NEW MAMMOTH FLOWERING VERBENAS

Altogether distinct and surprisingly beautiful. The aver age trusses measure nine to twelve inches in circumference, and the individual florets on properly grown plants over one inch across. They bloom freely, are vigorous in growth, and contain all of the beautiful new colors and shades. Mixed colors. Price, ioc per packet.

\section{- SINGLE VIOLETS}

Easy to raise and charmingly fragrant. Treat as you would Pansies. Price, mixed colors, white and purple, 10 per packet.

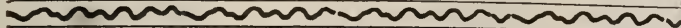

\section{A Child's Wild Flower Garden.}

Each packet contains a great variety of pretty flowers of easy growth. The mixture will be found to be both interesting and beautiful. Interesting because new flowers open daily that will be a source of endless delight to the children. Price, $10 \mathrm{c}$ per packet.

Imperial Seed Collection.

1 Aster, 2 Balsam, 3 Stocks, 4 Larkspur, 5 Zinnia, 6 Petunia, 7 Sweet Alyssum, 8 Verbena, 9 Phlox, 10 Poppy, 11 Pansy, 1 Daisy, 13 Marigold, 14 Sweet Pea, 15 Morning Glory, 16 Dian thus, 17 Mignonette, 18 Candytuft, 19 Cosmos, 20 Sweet William. Twenty packets for $50 \mathrm{c}$.

\section{PETUNIAS}

Fine Mixed-Choicest kinds. Price, $5 \mathrm{c}$ per packet. POPPIES

Danebrog-Large, single flowers of brilliant scarlet, with a large silvery-white spot on each of the four petals thus forming a white cross on a scarlet ground. Price, $5 \mathrm{c}$ per packet.

Paony Flowered-Large flowers and very double.

Price, $5 \mathrm{c}$ per packet.

The Mikado-Of pure white and brilliant crimsonscarlet, in striking contrast, the large double flow ers are of the most quaint, artistic beauty, with petals deeply cut, fringed and twisted like a Japanese Chrysanthemum. Price, 5c per packet.

Snowdrift-A grand new variety. The large pure white flowers are perfectly round and double; the petals are finels imbricated. Prica. $5 \mathrm{c}$ per packet.

A11 Colors, Mixed-Price, 10 per packet.

$$
\text { PORTULACA }
$$

Single-Fine mixed. Price, 5c per packet. RICINUS

(Castor Oil Bean.) Ornamental plants of stately growth and picturesque foliage, with brilliant colored fruit, producing sub-tropical effect. Fine for lawns, massing or center plants for beds. Mixed varieties. Price, $5 \mathrm{c}$ per packet.

\section{BOSTON SMILAX}

A most beautiful vine of easy culture. Price, $10 \mathrm{c}$ per packet.

\section{SALVIA}

The Salvia is now a standard bedding plant, and well does it deserve its honor. It stands heat and drought remarkably well, and its colors are very showy and intense.

Splendens-Large, scarlet; exceedingly showy and useful for cutting and for ornamental beds. Price, $5 c$ per packet.

\section{SWEET PEAS}

Sweet Peas are of flrst importance in every American garden, and we offer you a few of the best tested varieties. Should be sown four inches deep and cultivated like common peas; may be sown very early. Cut flowers early and pick off seed pods as fast as they appear.

Peach Blossom-A charming pink.

Emily Henderson-A standard white variety.

America-A fine red and white striped flower.

Celestial-Delicate pure lavender.

Deligh t-White with crimson edge.

Rising Sun-Flame-pink and orange shading.

Golden Gleam-A soft sulphur yellow.

Firefly-A splendid rich scarlet.

Captain of the Blue-A clear porcelain blue.

Boreatton-A rich dark crimson.

Any of the above varieties, 5 cents per packet; 15 cents an ounce.

SPECIAL OFFER-For 30 cents we will mail, post-paid, one packet each of the above ten varieties.

Eckford's Finest Mixture Sweet Peas-Very best, largest flowering varieties in endless combination of colors. Price, $5 \mathrm{c}$ per packet; $15 \mathrm{c}$ per ounce; two ounces for $25 \mathrm{c}$; one-fourth pound, $40 \mathrm{c}$; $\$ 1.50$ per pound.

SWEET WILLIAM (Dianthus Barbatus)

A very beautiful class of plants of extreme richness and diversity of color. They have been greatly improved of late years; on $\theta$ and one-half feet, hardy perennial.

Fine, Mixed Single-Price, all colors, $5 c$ per packet.

Double Flowering, Finest Mixed-From a splendid collection. Price, $10 c$ per packet.

\section{STOCKS}

Tree or Giant Ten Weeks Stock-Strong growers, bearing very strong and very double flowers on tall stems way above the foliage; splendid for cutting purposes. Price mixed colors, $10 \mathrm{c}$ per packet.

1 Dahlia, 2 Zinnia, 3 Petunia, 4 Stocks, 5 Pansy, 6 Poppy, 7 Sweet Pea, 8 Sweet William, 9 Marigold, 10 Cosmos, 11 Yerbena, 12 Mignonette. Twelve packets for $25 \mathrm{c}$.

The Practical Flower Garden.

1 Marigold, 2 Candy tuft, 3 Zinnia, 4 Poppy, 5 Nasturtium, 6 Balsam, 7 Petunia, 7 Sweet William, 8 Verbena, 9 Sweet Peas, 10 Mignonette. Ten varieties of seeds for $20 \mathrm{c}$.

The Collection of Fragrant Favorites.

1 Sweet Pink, 2 Mignonette, 3 Heliotrope, 4 Carnation, 5 Pansy, 6 Sweet Pea, 7 Violets, 8 Sweet William, 9 Musk, 10 Sweet Alyssum. Ten packets for $25 \mathrm{c}$. 


\section{Six Very Beautiful and Rare Foliage Plants.}

These handsome decorative plants are exceedingly beautiful and must be seen to be appreciated. South of Washington, D. C., they are all quite hardy; three of them are quite hardy here in Ohio. They all make very handsome specimens for pot culture and to those who desire choice foliage plants that are really beautiful and easy to grow and also something your neighbor has not got we heartily recommend these handsome plants.

\section{The Handsome Elergereen Foliage Plant, Acuba Japonica or Gold Dust Tree,}

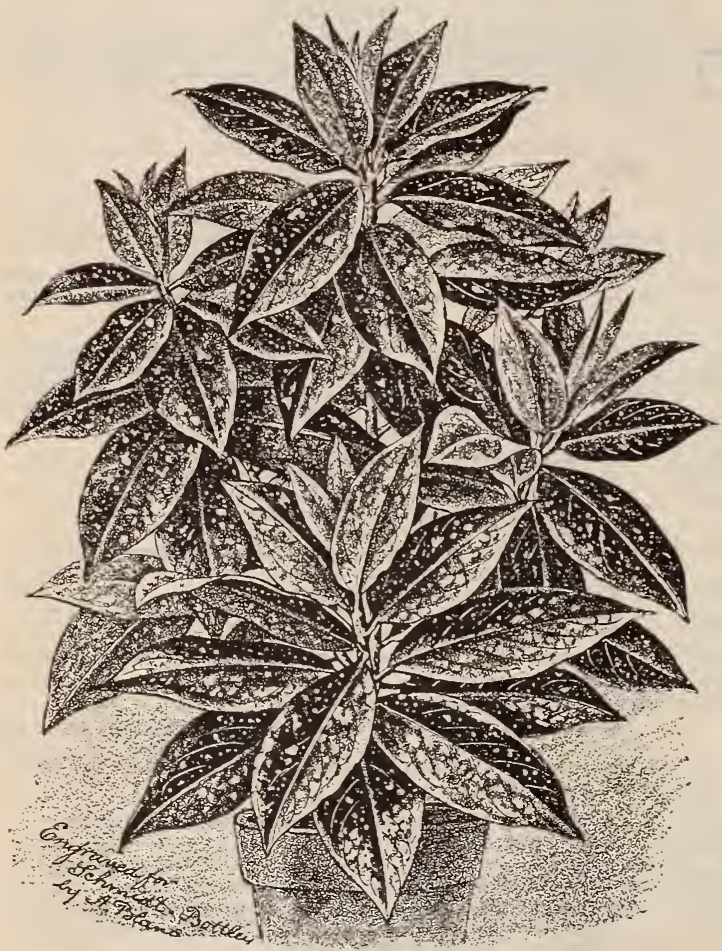

THE GOLD DUST TREE.

Beautifully variegated large laurel like foliage, mottled and splashed with bright golden-yellow. It is a superb house plant, retaining its hand some variegated foliage the year round. For the center of vases for Summer or Winter decoration it has few equals and as a specimen plant for the lawn or veranda it is without a peer. It is also nearly hardy and thrives alike in sunshine or shade. As an all round decorative plant it is unexcelled. We have asplendid lot of these beautiful plants and all lovers of choice and rare foliage plants should not fail to order one. Price, for fine, large handsome plants out of six inch pots, 50 cents each; very large specimens, splendid plants out of eight inch pots, $\$ 1,00$ each. See cut. Must be sent by Express, as they are too large to be sent by mall.

The Beautiful Retinospora Pisifera Sulfurea.

A beautiful compact Evergreen, with golden feathery foliage, beautiful in coloring and style of growth, and for cemetery planting is unsurpassed. Price for splendid plants 20 to 24 inches high, $75 \mathrm{c}$ each.

\section{The Lovely Retinospora Plumosa Aurea.}

Like the preceding, a plant of exceedingly great beauty; foliage soft, plume-like, of a golden color; close and compact habit; should be in every amateur collection. Price for very large fine plants, 20 to 30 inches high, $75 \mathrm{c}$ each.
The Splendid New Evergreen Cupressus Lawsoniana-A magnificent and rare Evergreen. It is one of the most graceful plants that grows with its elegant drooping branches. It is indeed grows tiful and is also very easy to grow; not quite hardy here in Ohio. Price for nice handsome plants, 20 to 30 inches high, $75 \mathrm{c}$ each.

The Beautiful Hardy Cupressus Nutkaensis-This beautiful and rare Evergreen is from Nootka Sound. It has splendid dark green foliage and is perfectly hardy. It is a grand variety. Price for strong piants, 20 to 30 inches high. $75 \mathrm{c}$ each.

The Charming Hardy Evergreen Buxus Arborescens (Boxtree)-A very pretty Evergreen, wirh small dark green leaves, grows very bushy and can be trained to any desired shape by trimming. It is quite hardy and we feel sure it will prove satisfactory to all who get it. Price for nice plants, 12 to 18 inches high, $50 \mathrm{c}$ each.

\section{A MAGNIFIGENT OFFER.}

We will send one of each of thesesix handsome Evergreens in very strong plants for only $\mathbf{\$ 3 . 0 0}$ Must be sent by Express; no fur ther discount on this offer.

\section{कलmen}

\section{Our Popular \$1.00 Express Collections}

ONLY ONE DOLLAR will buy any one of these rare Bargains in our One Dollar "Express Collections.'

These are just what many of our customers want, who have large beds to plant and do not care about having their plants named. We assure our flower-loving friends that every plant will be strictly first-class, both as to variety and size. Plants in these Collections will not be labeled, and can be sent only by express, purchasers paying express charges.

We will send any 6 Collections for $\$ 5.00$; any 13 Collections for $\$ 10$. When Ordering always say "Express" Collections, and always order by the number. $*$ * $*$

1-28 monthly ever-blooming Roses, choicest sorts. 2-30 grand, large flowering Chrysanthemums. These have all taken premiums or been certificated.

3-30 Pansy plants, the beautiful Butterfly strain.

4-30 Verbenas; will bloom all summer; all colors.

5-28 fragrant Carnation Pinks ; all colors.

6-25 nice Begonias, including some Rex.

7-10 Carnations, 10 Begonias, 10 Chrysanthemums.

8-10 ever-blooming Roses, 10 best Geraniums and 10 Chrysanthemums.

9-5 Fuchsias, 5 ever-blooming Roses, 5 Carnations, 5 Chrysantheumums, 5 Begonias and 5 Geraniums.

10-15 Tuberoses, 15 Gladoli, 1 big Caladium or Ele-

phant's Ear; guaranteed all sure flowering bulbs,
11 -1 very large Orange that has fruited, 1 large twoyear-old Jasmine, 1 large two-year-old giant flowering Hibiscus, and 4 big two-year-old everblooming Roses. This is one of our best offers.

12-30 choice flowering plants, ornamental plants and vines for a large vase. This will include a splenvid large flowering Canna for a center piece.

13-10 big clumps of our choicest French Cannas, all

14-30 beautiful many-varied Coleus.

15-1 large Azalea Indica, a grand plant; 1 fine 1 ‘alm, showing character leaves, and 2 fine two gearold Roses. Th's collection is a bargain.

FIVE UNMAMED 50G MAIL COLLECTIUNS.

21-13 lovely Tea Roses. These are all different, 50c.

$22-6$ fine hardy Roses and 6 splendid hardy Cl.mbing Roses, $50 \mathrm{c}$. 23- 6 double Geraniums, 6 single Geraniums; no two

24-15 beautiful Chrysanthemums, which will be a surprise to you in their strange forms and lovely colors, $50 \mathrm{c}$.

25-12 choice Carnation Pinks. All colors, 50c. 


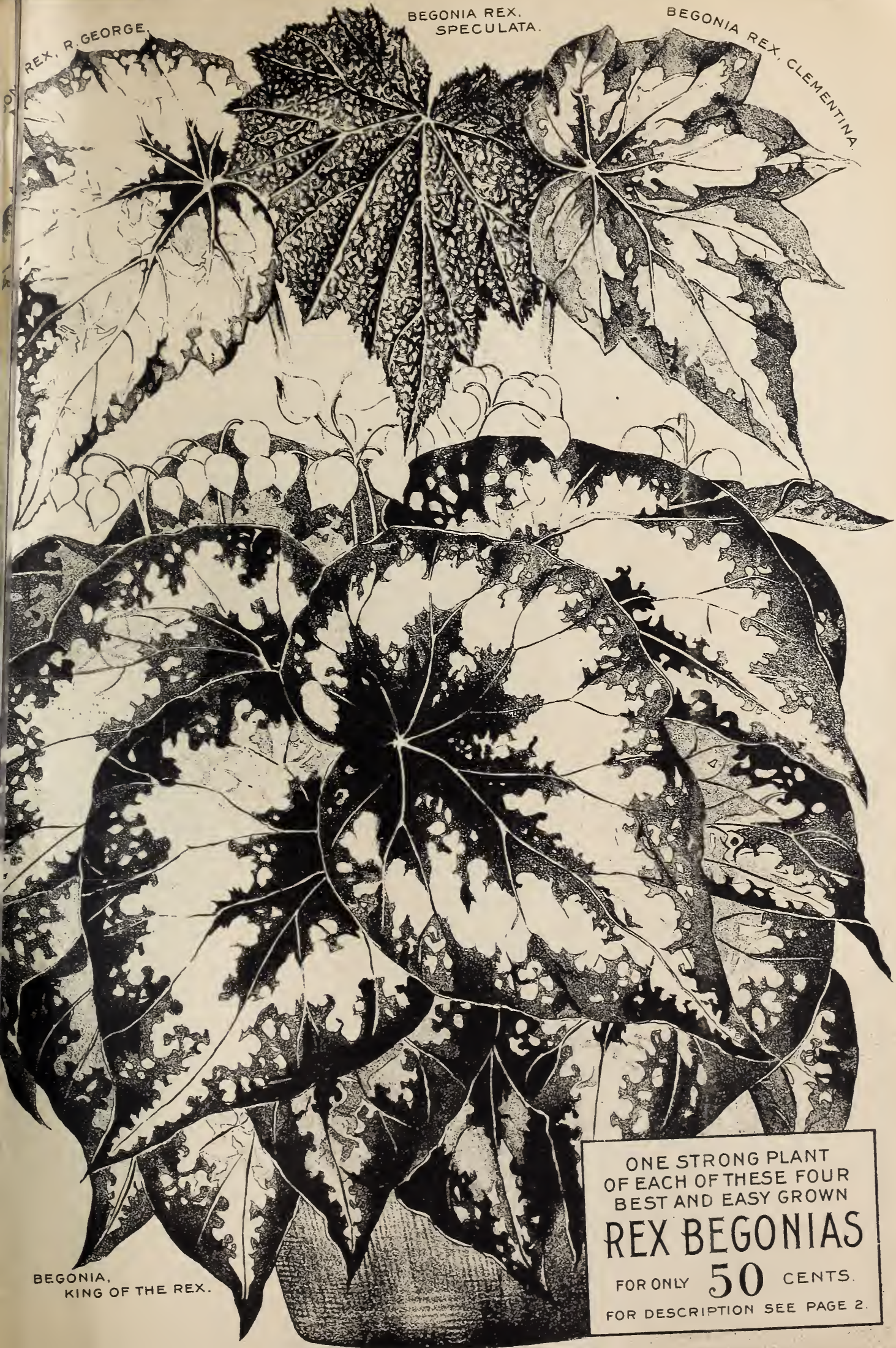




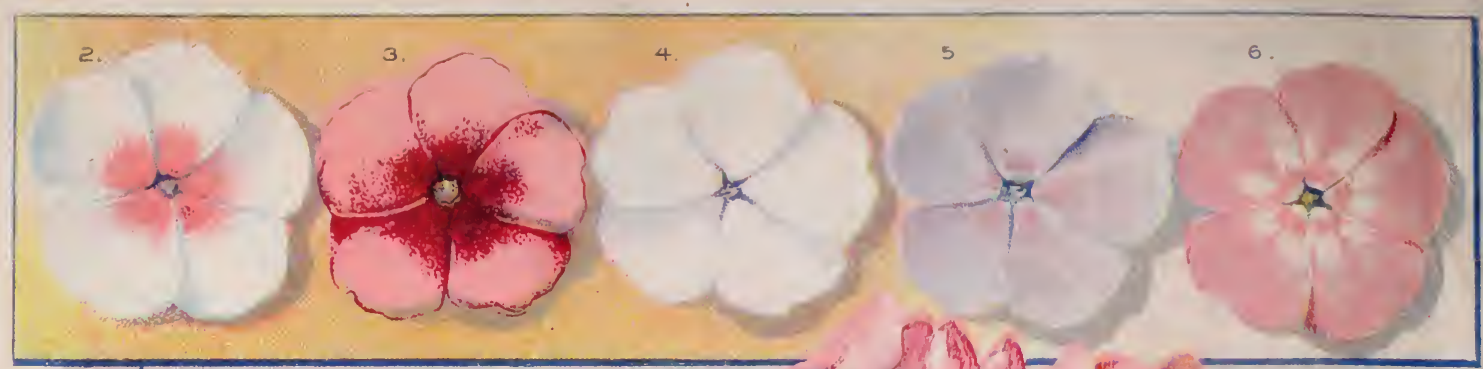

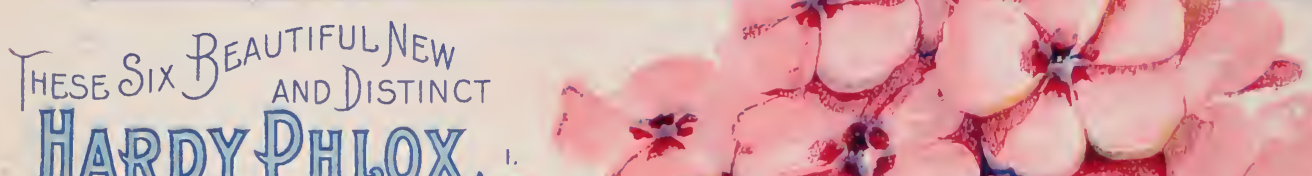

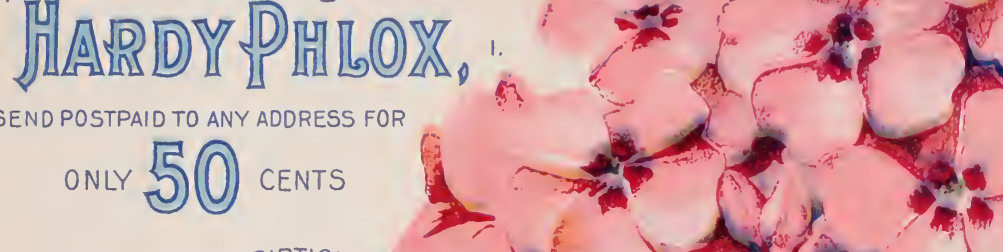
NeVt ${ }_{S \in E^{p A C E}}$. 